UNIVERSIDADE DE SÃO PAULO

FACULDADE DE FILOSOFIA, LETRAS E CIÊNCIAS HUMANAS

DEPARTAMENTO DE HISTÓRIA

PROGRAMA DE PÓS-GRADUAÇÃO EM HISTÓRIA ECONÔMICA

TOMÉ MIRANDA MALOA

\title{
HISTÓRIA DA ECONOMIA SOCIALISTA MOÇAMBICANA
}

Dissertação de Mestrado em História Econômica, apresentado ao Programa de Pós-Graduação em História Econômica da Faculdade de Filosofia, Letras e Ciências Humanas da Universidade de São Paulo. Orientador: PROF.DR. ANTÒNIO C. MAZZEO.

SÃO PAULO

2016 
Autorizo a reprodução e divulgação total ou parcial deste trabalho, por qualquer meio convencional ou eletrônico, para fins de estudo e pesquisa, desde que citada à fonte.

\author{
Catalogação na Publicação
}

Serviço de Biblioteca e Documentação

Faculdade de Filosofia, Letras e Ciências Humanas

MALOA, Tomé Miranda. História da economia socialista moçambicana/ Tomé Miranda Maloa; orientadora Prof. Dr. Antonio C. Mazzeo. - São Paulo, 2016. 162f.

Dissertação (Mestrado) Universidade de São Paulo, Programa de Pós-Graduação em História Econômica, 2016.

1.Economia socialista. 2. Moçambique. 3.FRELIMO. 4. "MarxismoLeninismo". I. Mazzeo, Antonio CII. Título. III. Título: História da economia socialista moçambicana.

CDD

MALOA, Tomé Miranda. História da economia socialista moçambicana. Dissertação apresentada à Faculdade de Filosofia, Letras e Ciências Humanas da Universidade de São Paulo para obtenção do título de Mestre em Ciências — Área: História Econômica. 
Aprovado em:

\section{Banca Examinadora}

Prof(a). Dr(a).

Instituição:

Julgamento: Assinatura:

$\operatorname{Prof(a).~Dr(a).~}$ Instituição:

Julgamento. Assinatura:

Prof (a). Dr (a). Instituição:

Julgamento. Assinatura: 


\section{SUMÁRIO}

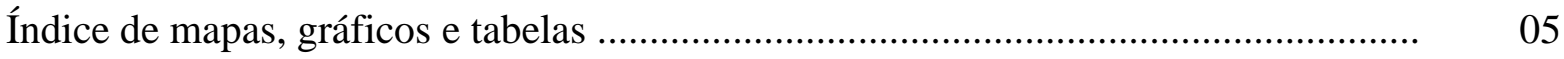

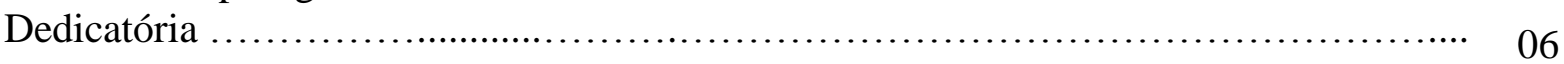

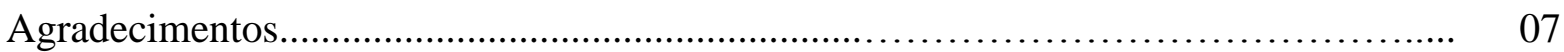

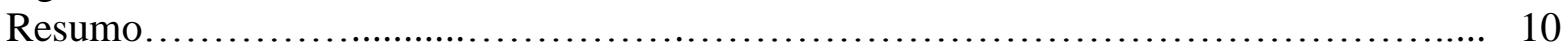

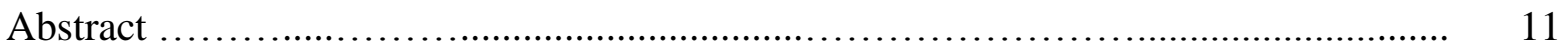

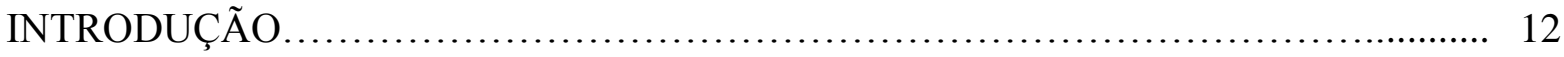

\section{PRIMEIRA PARTE}

DA ECONOMIA COLONIAL À SOCIALISTA (1885-1962)

Capítulo 1. O processo de organização econômica nas regiões centro e norte de Moçambique

Capítulo 2. As bases da organização da econômica no sul de Moçambique

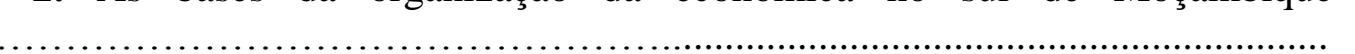

\section{SEGUNDA PARTE \\ A FORMAÇÃO DA ECONÔMIA SOCIALISTA: Da Guerra Colonial á Libertação (1962-1974)}

Capítulo 3. A socialização das zonas libertadas............................................................... 40

Capítulo 4. Últimos anos da colonização ....................................................... 54

\section{TERCEIRA PARTE}

A ECONÔMIA SOCIALISTA MOÇAMBICANA (1977-1986): Características Gerais

Capítulo 5. Das independências às nacionalizações ......................................... 63

Capítulo 6. A produção nas aldeias comunais ............................................................. $\quad 70$

Capítulo 7. Plano Estatal Central (PEC)................................................................. 86

Capítulo 8. Plano Prospectivo Indicativo (PPI) ……….............................................. 107

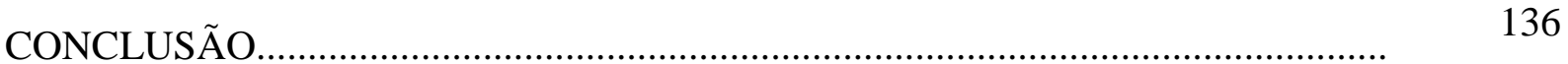

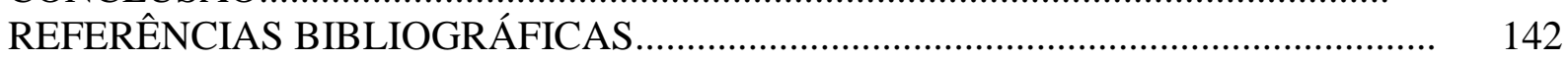




\section{ÍNDICE DE MAPAS, GRÁFICOS E TABELAS}

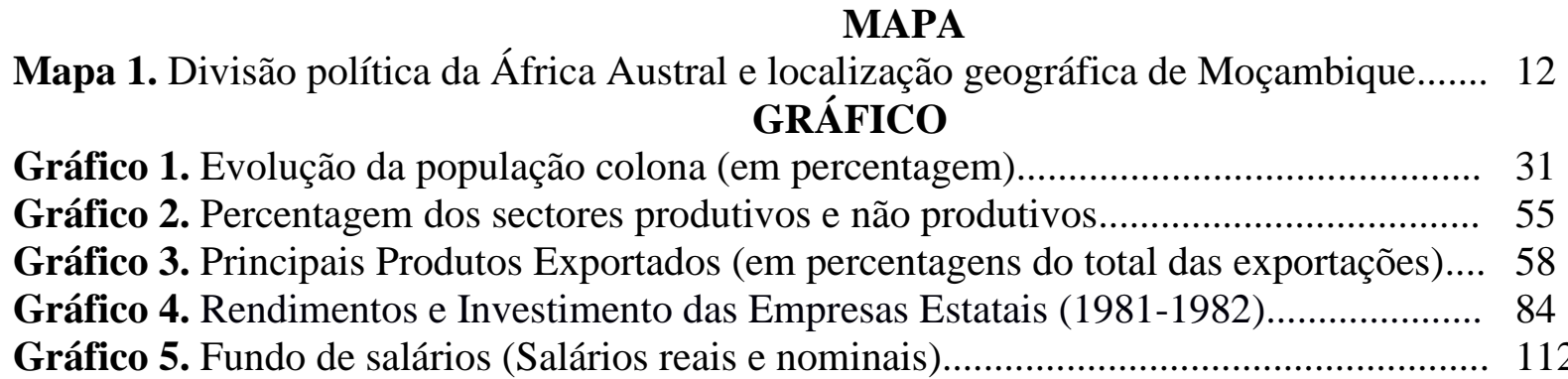

TABELAS

Tabela 1. O volume da força de trabalho no sul do país (percentagem da população ativa emigrada)

Tabela 2. Emigração para as minas da África do Sul (em milhares). 28

Tabela 3. Ocupação da terra para fins agrícolas, 1970 (hectares) 29

Tabela 4. Distribuição da terra, tamanhos das parcelas, 1970

Tabela 5. Exportações e importações (em percentagem, arredondado).

Tabela 6. Principais produtos importados (em percentagem do total das importações)...... 59

Tabela 7. Número de cooperativas 1977-1982 ............................................................... 73

Tabela 8. Número de cooperativas, por província e aldeias. 1977-1982 ......................... 74

Tabela 9. Número de áreas planificadas e cultivadas por Governo (1977-1982)............ 75

Tabela 10. Sector corporativo e sector familiar na campana de 1980-1981................... 83

Tabela 11. Produção social global (a preços constantes de 1980)................................... 112

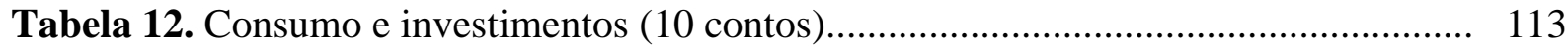

Tabela 13. Orçamento público (em 10 contos)........................................................... 113

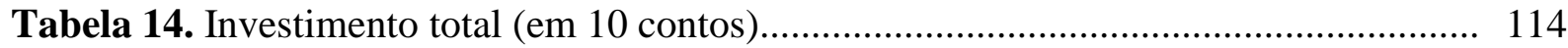

Tabela15 Balança de pagamento. 1975-1986. (contos 10)........................................... 115

Tabela16. Evolução dos preços de alguns principais bens exportados $(1975=100) \ldots \ldots \ldots . .116$

Tabela17. Importações, principais produtos (em percentagem do total de importações).... 117

Tabela18. Importações, principais origens (em percentagem do total de importações)...... 118

Tabela19. Exportações, principais cinco produtos (em percentagem do total).................. 119

Tabela 20. Evolução da produção comercializada agrícola (em $10^{3}$ toneladas)................. 120

Tabela 21. Evolução da produção comercializada agrícolas por sector social (em $10^{3}$

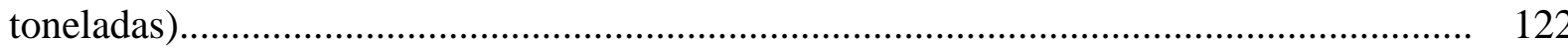

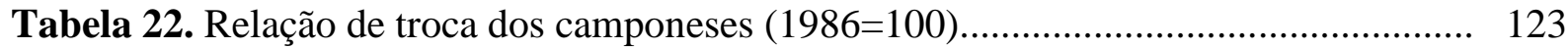

Tabela 23. Produção industrial (a preços de 1980, $10^{3}$ contos) ........................................ 125

Tabela24 Produção industrial de Carvão e Pesca (a preços de 1980, 10³ contos)............. 126

Tabela25. Transporte de carga e passageiros............................................................. 130 


\section{DEDICATÓRIA}

Dedico esta dissertação às famílias Buge e Maloa, dos meus pais Carolina e Miranda 


\section{AGRADECIMENTOS}

Permita-me mencionar explicitamente um determinado conjunto de instituições e pessoas com os quais devo um agradecimento às realizações deste trabalho, resultante de horas de leituras, dias em bibliotecas, longas conversas com colegas, professores e especialistas de várias áreas das Ciências Humanas. Destes encontros de aprendizagem, foram-se acumulando experiência acadêmica, recheada de certezas que gravitam sobre o trabalho, naturalmente, eu gostaria de agradecer às pessoas que discutiram comigo o conteúdo deste trabalho. A todo este mundo que se dilui no tempo e confunde-se na memória, deixo o meu reconhecimento.

Recebi comentários detalhados sobre a pesquisa por parte do meu orientador Prof. Dr. Antonio Carlos Mazzeo, uma referência intelectual, parceiro de inquietação e, sobretudo, um amigo. A este grande homem vai meu obrigado especial por encarar este desafio em orientar de forma árdua realização deste trabalho. A sua contribuição parte dos debates em aulas, conversas particulares que foram, de forma construtiva, importantes para a realização do trabalho, a ele devem o alargamento dos horizontes de interrogação e realce dos frutos.

Meu obrigado vai ao Prof. Dr. Osvaldo Coggiola, por ser uma pessoa que se dispôs a compor a banca de qualificação, me deixando com muito entusiasmo a respeito dos desafios que eu deveria enfrentar. Acompanhou com atenção as minhas preocupações sobre as formas de abordagem da história do socialismo em Moçambique e acolheu com uma compreensão cuidadosa as formas de enfrentar ilustrar a economia socialista na pesquisa, trazendo uma abordagem construtiva e necessária para o conhecimento da realidade da sociedade moçambicana.

Deixo o meu reconhecimento ao Prof. Dr. Luis Henrique Pessador uma referência nos estudos sobre Moçambique, parceiro de inquietação e, sobretudo, um amigo.de quem tive muitos conhecimentos sobre Moçambique. Agradeço em especial pelo seu contributo nos debates do Grupo de Estudo de Mediação e Alteridades (GEMA) e pela sua forma construtiva, de ver a realidade Moçambicana Merecem aqui agradecimento pela ajuda, hospitalidade e carinho por mi recebido no grupo, GEMA onde debatemos muitas vezes a história de Moçambique com grande intensidade. Vai ainda um especial obrigado pela disposição de participar de compor a banca de da defesa.

O progresso significativo do trabalho teve melhor êxito graças à disposição do Prof. Dr. 
Carlos de Toledo de também participar na minha banca de mestrado, acrescentando de forma intelectual, muitas contribuições sobre os desafios que eu deveria ter em conta, e também, em minha constante convivência com o professor e amigo Carlos e a sua esposa Profa. Dra. Marta Jardim, pessoas que tenho muito a agradecer pelas idéias que trouxeram para esta pesquisa. Merecem aqui agradecimento pela ajuda, hospitalidade e carinho, ao me receberem em sua casa, onde debatemos muitas vezes a história de Moçambique com grande intensidade. Vai ainda um especial obrigado pela disposição e os brilhantes comentários que fizeram com que o trabalho fosse uma realidade.

Outro responsável pela elaboração deste trabalho foi o Prof. Dr. Rodrigo Ricupero, que aceitou ser o meu orientador durante a elaboração do projeto inicial desta dissertação. Com rara sensibilidade, ele soube associar à exigência do seu rigor científico a paciência e sabedoria; concedeu-me grande espaço e liberdade, que foram de extrema importância para o trabalho. Para ele disponho o meu obrigado.

Agradeço ao Prof. Dr. Wilson Barbosa, com quem tive o prazer de ter aulas brilhantes, longas conversas sobre o socialismo. De extrema importância foram às reflexões que trouxe para o projeto, ao apontar lacunas, erros e incoerências, assim como, formas de abstração, idéias e discursos do socialismo e as suas realizações concretas. Porém, todas as contribuições antecedidas e completadas por outros, que o professor deixou no trabalho, foram acompanhadas pela sua vivência de extrema importância em Moçambique, donde nos trouxe memórias da situação vivida pelo governo no período pós-independência.

Graças aos amigos do Departamento de História da USP, a quem devo as contribuições em seminários e debates. Meu obrigado, em especial ao ,Mestre Eduardo Januário, que sem ele este trabalho nunca teria "conhecido a luz do dia". Além de um colega e cúmplice, Eduardo foi se transformando, progressivamente, em um parceiro de inquietação e, sobretudo, da história da África, que tanto amamos. Como uma referência intelectual, eu devo ainda mais pela atenção dada por ele, nas leituras do extenso trabalho, a gentileza de reler cuidadosamente cada etapa do desenvolvimento do trabalho, e aceitar comentar livremente, no todo ou em parte, os seus reflexos.

Permita-me agradecer a Profa. Dra. Andréia Peres a qual devo uma imensa gratidão para a realização deste trabalho, pela leituras e conversas sobre Moçambique, principalmente, o que desta aprendizagem, surgiram idéias para a melhoria do trabalho Por muito agradeço a sua 
colaboração acadêmica, paciência, certezas nas discutições dos conteúdos do trabalho.

Nessa caminhada, contei com os incentivos intelectuais descritos nas constantes conversas com Dr. Joaquim Maloa, meu irmão e amigo, que tanta contribuição deixou para esse trabalho. Ao meu irmão devo, e saibam que nunca vou poder pagar, por sua compreensão, respeito e, acima de tudo, muita recomendação literária para que este trabalho fosse uma realidade. A minha gratificação se estende ainda pela disponibilização de sua biblioteca e pelo empréstimo de diversos itens raros da sua coleção pessoal.

Outras pessoas e instituições que me incentivaram e apoiaram nesta pesquisa de diferentes maneiras, seja regularmente ou ocasionalmente, como; dr. Dayron Tafir, Dr. Dieng Mamadou, Elisangela da Silva, dr. Jean Gustavo,Dr. João Moreno Mestre Santos Elvander, dra. Suzana Alves dra.Isabel de Queiroz, Dra. Thais Mantovanelli, entre outros, pela atenção generosa.

Por fim, mas não menos importantes a minha pessoa, tenho uma dívida incalculável com as pessoas que gostaria de agradecer, como as minhas irmãs; Alina, Delfina e Páscoa, e outras individualidades que não serão aqui identificados. Devo lembrar para sempre a dívida que tenho, pelas importantes contribuições que foram dando ao longo do mestrado. Aos amigos, colegas e professores e familiares, que me ajudaram de diversas maneiras, a todos: o meu obrigado.

Agradeço ao CNPq e à Ciência e Tecnologia de Moçambique pela bolsa atribuída para que este trabalho fosse realizado sem entraves. 


\section{RESUMO}

A presente Dissertação de Mestrado tem por objetivo resgatar através da História os aspectos que mais marcaram a organização econômica moçambicana, principalmente, entre os anos 1975 a 1986. Período este em que a FRELIMO (Frente de Libertação de Moçambique) adotou o Marxismo-Leninismo como o modelo de organização econômica, política e social. Porém, faz também um rescaldo dos aspetos relacionados com a organização econômica colonial portuguesa, depois herdada pelo primeiro governo independente do país. Especificamente, este estudo faz uma abordagem das opções estruturais do modelo de desenvolvimento socialista de Moçambique pós-colonial até os finais dos anos oitenta. Dentro deste processo, assinalo que o meu objetivo não consistia na apresentação de uma organização geral da História da economia socialista moçambicano, mas em inscrever o meu contributo na continuidade de uma reflexão multifacetada, iniciada há largos anos pelas gerações anteriores.

Palavras-chaves: Economia socialista. Moçambique. FRELIMO. Marxismo-Leninismo. 


\begin{abstract}
This Master Dissertation objective rescues the aspects that marked the Mozambican economic organization, especially between the years between 1975 and 1986, when FRELIMO (Mozambique Liberation Front) adopted Marxism-Leninism as the model of economic, political and social organization. However, it also makes an aftermath of the aspects related to the Portuguese colonial economic organization, which was later inherited by the first independent government in the country. Specifically, this study is an approach to structural options of the socialist model of development of post-colonial Mozambique until the end of the eighties. Within this process it has developed a centrally planned economy to overcome the inherited colonial capitalism in order to ensure compliance of the State leftist politics with the people's interests.
\end{abstract}

Keywords: socialist economy. Mozambique. FRELIMO. Marxism-Leninism. 


\section{INTRODUÇÃO}

O propósito deste estudo é resgatar de forma objetiva os aspectos históricos que mais marcaram a organização econômico-socialista moçambicana entre os anos 1975 a 1986. Assim, iniciamos por localizar geograficamente Moçambique na África Austral, localiza-se na costa sul - oriental, estendendo-se as suas fronteiras ao norte fronteira com a Tanzânia, noroeste com o Malawi e a Zâmbia, ao oeste com o Zimbábue e o sudoeste com a África do Sul e o Reino da Suazilândia ${ }^{1}$. Como se pode observar no mapa 1 a baixo que ilustra a divisão política da África Austral e a localização geográfica de Moçambique.

MAPA 1.

Divisão política de África e localização geográfica de Moçambique

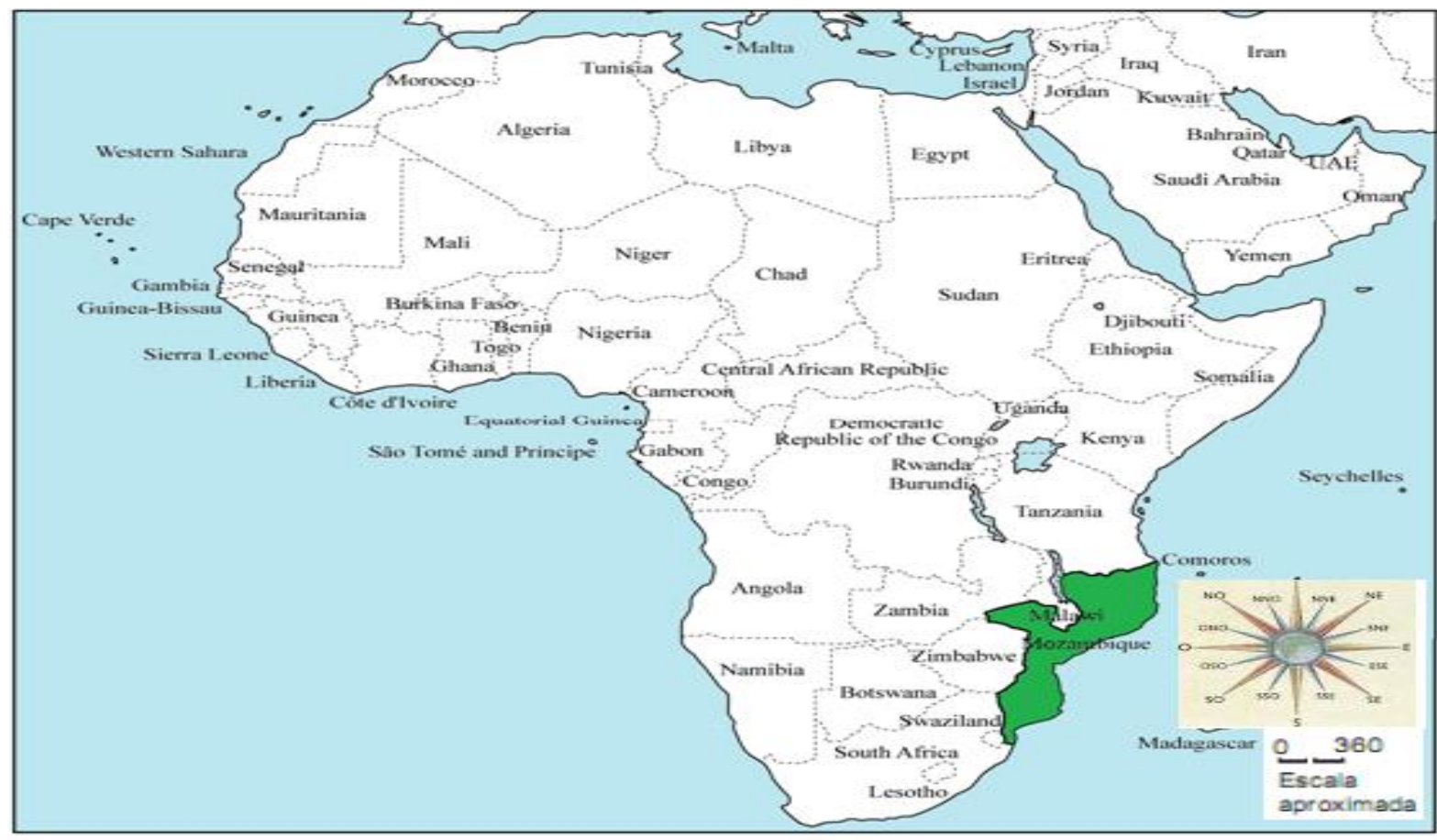

Fonte: Jack Maxfield apud Luis Henrique Passador (2011). Adaptado pelo autor.

A dissertação traz um rescaldo dos aspetos relacionados com a organização econômica

\footnotetext{
${ }^{1}$ Ver. ARAÚJO, Manuel.O sistema das aldeias comunais em Moçambique: transformações na organização do espaço residencial e produtivo.( Tese de Doutorado em Geografia Humana -Universidade de Lisboa. Lisboa), 1988; MUANAMOHA, Ramos. Tendências históricas da distribuição espacial da população em Moçambique. (Dissertação de Mestrado em Demografia - Centro de Desenvolvimento e Planejamento Regional da Faculdade de Ciências Econômicas da Universidade Federal de Minas Gerais, Minas Gerais. Belo Horizonte), 1995.
} 
colonial portuguesa, que, de modo significativo, enquadrou-se com a independência nacional em 1975 na economia socialista. Porém, entre os objetivos, outra prerrogativa do estudo é abordar as opções estruturais do modelo econômico socialista em Moçambique até aos finais da década dos anos 1980. Ao examinar esses fatos, pretendemos, assim, localizar os aspetos econômicos que estiveram registrados no primórdio da economia socialista.

Para os fins deste estudo, uma das mais importantes implicações da economia moçambicana é que a mesma se expandiu condicionada por forte dependência do financiamento dos investimentos externos e crises internas vindo do crescimento de negócio feito pelo Governo que empurram Moçambique para "armadilha de dívidas". Acompanhada da queda dos preços das matérias-primas, sobem os créditos no mercado secundário. Sem a degradação da taxa de juro, o pagamento se torna uma "ginástica" para o Governo moçambicano, uma vez que o orçamento é deficitário. Entretanto, a escolha desse objeto prende-se à intenção de perceber, como o estado socialista numa altura em que a economia estava em baixo, com a forte desvalorização da moeda, e com uma redução da sua capacidade de prosseguir com políticas econômicas mais amplas projetou a sua manutenção.

O presente estudo está dividido em três partes. A primeira parte tem como tema $d a$ economia colonial à socialista (1885-1962). Seu objetivo é mostrar, de forma mais direta e específica, como se processou a organização econômica portuguesa em Moçambique. Porém, historicamente, o núcleo central desta parte consiste em trazer uma reflexão dos aspetos que mais consolidaram a econômica colonial em Moçambique e que foram posteriormente usadas pelo novo governo socialista. Dessa forma, a primeira parte subdivide-se em dois capítulos: O primeiro capítulo, o processo da organização econômica colonial nas regiões centro e norte de Moçambique, procura apresentar a formação da economia colonial no centro e norte de Moçambique século XX. O segundo capítulo, sob o título, organização econômica no sul de Moçambique, tem como objetivo mencionar como as políticas portuguesas de exploração se processou na zona sul de Moçambique. Pressupomos que facilita-nos a perceber mais adiante como a organização da economia colonial dificultaria o desenvolvimento do socialismo. Assim sendo, este capítulo esta subdividido em três partes: A primeira é denominada força de trabalho, procura apontar a influência da África do Sul na organização econômica de Moçambique, principalmente nos acordos de fornecimento de serviços e mão de obra assinado entre os dois países. A segunda parte, com o tema, Os colonatos agrícolas, tem como objetivo de evidenciar a 
importância dos colonatos na organização da economia colonial e a sua ligação a possibilidade de escoamento da produção agrícola. A terceira com o tema, Indústria Principiante, mostrar quais foram às formas de produção industrial que emergiram no período, é, no entanto, importante compreender que elas passaram a estar integradas na economia de Moçambique durante o socialismo.

A segunda parte tem como tema a formação da economia socialista: da guerra colonial a libertação (1962-1974). Seu objetivo é contextualizar a situação econômica de Moçambique nos últimos anos da colonização. Esta caracterização serviria para melhor compreendermos a opção pelo socialismo e as suas dificuldades de realizações dos objetivos. A segunda parte subdivide-se em dois capítulos, que são:

O terceiro capítulo intitulado, socialização das zonas libertadas. Tem como objetivo expor o processo da socialização nas zonas libertadas. Pressupomos que facilita-nos a perceber os primeiros passos do desenvolvimento do modelo econômico socialista em Moçambique. Este capitulo, esta estruturado em dois tópicos: O primeiro denominado o surgimento das zonas Libertadas. Procura mostrar como foram surgindo zonas Libertadas em que foram se construindo as primeiras formas de organização econômica da FRELIMO em moldes socialista. O segundo tem como título, organização econômica das zonas Libertadas. Procura apontar como a organização econômica das "zonas libertadas", estava estruturada atentando, principalmente, para a experiência das cooperativas.

O quarto capítulo, sob o título, últimos anos da colonização, tem como objetivo caracterizar a estrutura econômica colonial, para melhor compreender quais foram às heranças econômicas colonial em Moçambique. De uma forma geral, pretendesse também, compreender a função objetiva do governo colonial de maximizar a extração de recursos através da exploração massiva.

A terceira parte tem como tema a economia socialista em moçambicana (1977-1986): Suas carateristicas gerais. Procura mostrar os "passos da organização econômica socialista" desde a independência de Moçambique, celebrada em 1975, quando a política é voltada para instauração do socialismo. Esta parte divide-se em quatro capítulos: O quinto capítulo, sob o título, Das Independências às nacionalizações. Faz referência a situação que levou a nacionalização em Moçambique como uma das primeiras políticas da estatização rumo à organização socialista. Assim sendo, o sexto capítulo, sob o título, A Produção nas Aldeias 
Comunais, objetiva mostrar os mecanismos socialistas usados para realizar a organização da força de nas zonas rurais para que se estruturem uma sociedade revolucionária. Em última análise, as aldeias mostram como as populações viveriam organizadas para desenvolverem a produção coletiva, promovendo intercâmbio dos seus conhecimentos.

O sétimo capítulo, sob o título, Plano Estatal Central (PEC), objetiva mostrar como a FRELIMO consolidou a posição socialista nas diretrizes econômicas. Especificamente, apresentar o primeiro instrumento legal da economia socialista em Moçambique. Assim sendo, este capítulo esta subdividido em três pontos: O primeiro é denominado organização econômica, em que, procura mostrar como estava organizada e planejada o desenvolvimento do primeiro plano socialista em Moçambique. Para tal, espelha as medidas de ajuste econômico impostas pelo plano. O segundo ponto, com o tema, gestão das empresas estatais, tem como objetivo mostrar como era à gestão planejada de algumas empresas estatais e as suas prioridades no desenvolvimento econômico do socialismo moçambicano. O terceiro com o tema, características das empresas estatais. Este ponto procura caracterizar o processo de produção nas empresas estatais organizadas no PEC. Nesta perspectiva da construção do socialismo faz uma abordagem partindo de algumas empresas industriais e agrícolas de grande dimensão e consideradas importantes para a economia socialista.

Oitavo capítulo, com o título, Plano Prospectivo Indicativo (PPI), tem como objetivo mostrar como PPI procurava consolidar as diretrizes econômicas socialista em Moçambique. Entretanto, este capítulo esta subdividido em cinco tópicos: O primeiro é denominado $A$ estratégia de reconstrução econômica. Este tópico procura mostra como foi à estratégia de reconstrução econômica do segundo processo revolucionário socialista em Moçambique, que teve inicio com PPI. O segundo com o tema Crescimento econômico. Faz uma menção ao Crescimento econômico de Moçambique durante a execução do PPI. O terceiro, com o tema $O$ setor agrário, faz uma caracterização da exploração agrária de Moçambique durante a implementação do PPI. Entretanto, faz referencia ao desenvolvimento de algumas empresas estatais do ramo agrário em que foram concentraram elevados volumes de investimentos públicos e foi à priorização na afetação de recursos após a independência. O quarto tem como tema $o$ setor industrial, objetiva caracterizar o setor industrial durante a implementação do Plano Prospectivo Indicativo (PPI). Num período em que o setor industrial foi objeto de protecionismo, como eram autorizadas importações de bens correntes com a produção nacional e as exportações 
de matérias para abastecimento das fábricas. O quinto tópico, com o tema $O$ setor do transporte. Este tópico caracterizar a situação do setor dos transportes durante a implementação do PPI. Porém, mostra como foi se procedendo a evolução política do transporte em Moçambique, o seu funcionamento e dificuldades para o reforço da idéia de um projeto de desenvolvimento econômico socialista a um longo prazo. 
PRIMEIRA PARTE

DA ECONOMIA COLONIAL À SOCIALISTA (1885-1962) 


\section{I-CAPÍTULO}

\section{O Processo da Organização Econômica nas Regiões Centro e Norte de Moçambique}

Esse capítulo tem como objetivo apresentar a formação da economia colonial no centro e norte de Moçambique século XX. Num período em que se pode afirmar que Moçambique começava a organização econômica colonial pela pressão das decisões tomadas na Conferência de Berlim (realizada a 15 de novembro de 1884 a 26 de fevereiro de 1885), que obrigava o poder colonial ocupar totalmente o território, militarmente e administrativamente ${ }^{2}$. Essa conferência teve como objetivo organizar, por meio de regras, a ocupação da África pelas potências coloniais ${ }^{3}$. Desta partilha colonial, Portugal, por falta de capital financeiro e humano para pacificar a região, recorreu à abertura aos capitais estrangeiros ${ }^{4}$. Assim sendo, Portugal cedeu um terço do território moçambicano, uma imensa região localizada na zona centro e norte do país, para a administração das companhias de estatuto majestáticas ou soberanas e as de estatuto arrendatárias ${ }^{5}$. Duas grandes companhias majestáticas se fizeram representar durante a ocupação efetiva em Moçambique $^{6}$. Por um lado, estava a Companhia de Moçambique, localizada no centro, em que englobava as atuais províncias de Sofala e Manica $^{7}$, e, do outro lado, estava a companhia do

\footnotetext{
${ }^{2}$ Ver. PEISSIER, René. História de Moçambique : Formação e oposição 1985-1918. Lisboa. Vol2. Editorial Estampa, 1988.

${ }^{3}$ Durante esta conferência, Portugal apresentou um projeto, o famoso "Mapa Cor-de-Rosa", que consistia em ligar Angola a Moçambique para haver uma comunicação entre as duas colônias, facilitando assim o comércio e o transporte de mercadorias. O projeto não deu certo (SERRA, 1986 ${ }^{\mathrm{a}}$ ).

${ }^{4}$ Abertura não consistia somente em investir em infra-estruturas de base, necessárias para promover a produção, mas também em incentivar as funções de caráter administrativo (MALOA, 2016).

${ }^{5}$ Chamadas de majestáticas pelos direitos que eram atribuídas pelo rei em Portugal, elas eram quase soberanas nessas parcelas de território e em relação a seus habitantes, enquanto que, as companhias arrendatárias não tinham direitos iguais porque arrendavam as terras das outras companhias ou do estado sem muitos direitos soberanos (GENTILI, 1999).

${ }^{6}$ As companhias criadas tinham investimentos em capitais privado, com base no trabalho de uma mão-de-obra com baixa remuneração, por meio de trabalhos forçados. Para mais informações sobre o trabalho ver. ZAMPARONI, Valdemir. "Chibalo: Trabalho livre, trabalho escravo? As discussões em torno do trabalho compulsório em Moçambique colonial". In: Escravatura e Transformação Culturais - África Brasil - Caraíbas.. Atas do Colóquio Internacional. Universidade de Évora. Lisboa. 2000.

7 Joaquim Carlos Paiva de Andrada, oficial do exército português e adido militar em Paris, logrou fundar, em conjunto com outras personalidades portuguesas, a Companhia Nacional de Moçambique, que teve concessão entre 1888-1942, quando prescreveram os poderes majestáticos da Companhia de Moçambique sobre os distritos de Manica e Sofala, sendo este, incorporado na administração do Estado português em 1942, com o fim da soberania das companhias. Mas as empresas continuaram existindo como empresa agroindustrial e comercial, desenvolvendo um grupo de empresas que, na década de 1960, constituiu-se no Entreposto Comercial - Veículos e Máquinas S.A (CARVALHO, 2012).
} 
Niassa ou Nyassa, localizada no norte do país, nas atuais províncias do Niassa e de Cabo Delegado $^{8}$.

Também conhecidas pelos seus privilégios, as companhia seriam entidades privadas, com autonomia administrativa e financeira, portadoras do direito de organizar forças militares e paramilitares $^{9}$. As companhias majestáticas era um Estado dentro de outro Estado. Essas companhias tiveram as ações do capital social vendidas principalmente na Inglaterra, França e Alemanha. Os acordos celebrados entre o governo e as companhias, sob a forma de Carta, salvaguardavam os direitos de soberania ao Estado português. No entanto, concedia a tais companhias outras atribuições executivas. Um exemplo pode ser notado na Carta de 1892 da Companhia de Moçambique, que previa que esta sociedade anônima (S/A) tinha ao seu poder o direito de efetuar concessão mineira a outras pequenas companhias e que, inclusive, poderia emitir moeda e selos postais. Além dessas prerrogativas, era concedida exclusividade à companhia ${ }^{10}$ para a construção e a apropriação de comunicações terrestres, marítimas e portos. Entretanto, os direitos passavam da exploração da indústria mineira à pesca de coral e pérola, caça de elefantes etc., além do domínio de todos os terrenos livres da área concedida ${ }^{11}$.

Todavia, a contrapartida em benefício do Estado colonial estava na prerrogativa de que as companhias tinham a obrigação de guarnecer os territórios controlados por eles, assim como

\footnotetext{
${ }^{8}$ A Companhia do Niassa foi uma das companhias majestáticas formada por alvará régio de 1890 . Os termos da concessão foram dados em 1891. No entanto, o grupo português não tinha capacidade financeira para a operação da Companhia e, em 1892-93, um consórcio de capitais franceses e britânicos comprou a concessão, mudando a sua sede para Londres. Entre 1897 e 1908, três grupos financeiros controlaram sucessivamente a Companhia. O primeiro foi o "Ibo Syndicate", depois "Ibo Investment Trust", a partir de 1908, foi dominada pela "Nyassa Consolidated", com forte participação de capital mineiro sul-africano, porém, um bancário alemão comprou a maioria das acções da Companhia, na mira de uma partilha de Moçambique entre aquele país e a Grã-Bretanha. Com o início da Primeira Guerra Mundial, o governo britânico confiscou as ações alemãs e entregou-as a um grupo financeiro inglês. Os administradores da Companhia do Niassa desinteressam-se pelo seu desenvolvimento e, em 1929, a Companhia extingue-se, passando o território para a administração direta do governo colonial (MEDEIROS, 1997).

${ }_{9}$ As companhias majestáticas organizaram as plantações dentro dos interesses da administração portuguesa, desenvolveram um sistema monetário que pudesse circular o capital para responder à base tributária, em que a medida incluía a obrigatoriedade dos homens válidos para pagarem impostos em produtos ou horas de trabalho. E, com base nos procedimentos de cobrança de impostos, começaram a se organizar as grandes plantações agrícolas. Dos privilégios concedidos à Companhia de Moçambique, por exemplo, esteve entre o controlo dos correios locais e a publicação de selos, para além da emissão de notas. Com a prescrição dos poderes majestático da companhia a 18 de julho de 1942, terminaram também nessa data os privilégios soberanos da companhia (CARVALHO, 2012).

10 Por exemplo, na companhia de Niassa, uma das prerrogativas na cobrança de impostos e taxas aduaneiras sobre importações e exportações e, a partir de 1898, na emissão de selos próprios para uso no seu território, por decreto (MINISTÉRIO DA MARINHA E ULTRAMAR, 1897, BOLETINS DA COMPANHIA DO NIASSA, 1903, 1908, 1911).

${ }^{11}$ Ver. COSTA. Inês Nogueira. No centenário da Companhia de Moçambique, 1888-1988. In: Arquivo Histórico de Moçambique. Cidade da Beira. Maputo: Arquivo Histórico de Moçambique. Boletim Semestral, nº 6 especial. Outubro de 1989.
} 
poderiam ter que colaborar com tais guarnições quando solicitado pelo Estado. As Companhias eram obrigadas a respeitar os direitos aduaneiros e a proteção concebida aos produtos nacionais na alfândega da província de Moçambique. As Companhias tinham a obrigação ainda de construir infra-estruturas sociais e físicas (cidades, vias, estradas de ferro, pontes, escolas, hospitais, telégrafo, bancos e outras instituições de créditos), e também submeter ao governo os tratados e convenções celebrados com os régulos ${ }^{12}$. Outras prerrogativas indicavam que as companhias deveriam respeitar os tratados efetuados entre o governo português e outras colônias, estabelecer no território mil famílias de colonos (no prazo de cinco anos), manterem os regimes municipais e programá-los em outras regiões ${ }^{13}$ e, sempre que a condição permitisse, usar a bandeira portuguesa (a qual poderia juntar com outros distintivos), assim como, organizar forças policiais e militares ${ }^{14}$

Além disso, as Companhias cediam ao Estado colonial 10\% de todas as receitas produzidas por ano, e reduzia a percentagem dos lucros líquidos para 2,5\%, taxa que se elevaria para 5\%, quando os lucros fossem superiores a 10\%. Ainda tratando dos deveres das Companhias mediante o Estado colonial é importante destacar que elas tinham a obrigação de comunicar ao governo colonial, ou a seus representantes, todos os tratados e convenções com os nativos, deste modo, todas as relações deveriam ser confirmadas pelo governo colonial, assim como, qualquer litígio $^{15}$, já que o regime jurídico estava sob o decreto do governo colonial e os magistrados judiciais continuavam a ser de nomeação régia. Além disso, as companhias tinham também que sustentar missões educativas para a instrução primária em arte ofícios ${ }^{16}$.

Essas condições efetivaram a fundação de cidades, a exemplo da cidade da Beira,

\footnotetext{
${ }^{12}$ Chefias locais.

13 Nestas circunstâncias, começou a aparecer na economia urbana, hotéis, mais de uma dezena de empresas de importação e exportação de capital inglês, agências de seguro e navegação marítima, dezenas de lojas de tecidos e moda, empreiteiros públicos, mercearias, armazéns, padarias, açougues, restaurantes, dezenas de bares, farmácias e drogarias, tabacarias. Além disso, dezenas de pequenas oficinas de artesãos e prestadores de serviços como ferreiros, alfaiates, barbeiros, ourives, relojoeiros, carroceiros, fotógrafos e, naturalmente, uma empresa funerária (MALOA, 2015).

14 Ao conceder tais poderes às companhias particulares, o Estado colonial receberia em troca a pacificação do território - lembrando que as revoltas contra a administração portuguesa foram quase endêmicas na região central de Moçambique, atingindo o seu apogeu com o fim da rebelião de Barué em 1920 (COSTA, 1989; NEWITT, 1997; MOSCA, 2005).

${ }^{15}$ Ver. MEDEIROS, Eduardo da Conceição. História de Cabo Delgado e do Niassa (c. 1836-1929), 1997.

${ }^{16}$.Vejam-se, especialmente: MENDES, Rui. A cidade colonial e a estruturação do território em Moçambique: a evolução urbana de Lourenço Marques/Maputo, Beira, Nampula e Porto Amélia/Pemba. Tese (Doutorado em Geografia). Faculdade de Letras da Universidade de Porto. Porto, 2011; MUHATE, Isaias. Alguns aspetos do retrato histórico e perspectiva do porto da Beira. In: Arquivo Histórico de Moçambique. Cidade da Beira. Maputo: Arquivo Histórico de Moçambique. Boletim Semestral, n 6 especial. Outubro de 1989.
} 
fundada pela Companhia de Moçambique ${ }^{17}$, com uma economia projetada na base das receitas provenientes das condições geográficas da região, com a ligação da utilidade do uso do porto e a ligação da estrada de ferro para o hinterland conectando Beira a Salisbury/Harare (capital do atual Zimbabué $)^{18}$. A estrada de ferro, construída entre 1893 e 1899, foi uma obra realizada pela Beira Railway Company, consórcio da Companhia rodesiana Britsih South África Company (BSAC), de Cecil Rhodes ${ }^{19}$. A estrada atravessava 160 quilômetros da baixa savana em direção ao sudoeste passando pelo distrito de Manica, condições que permitiram oferecer melhor estrutura para Rodésia do Sul (atual Zimbabué) ${ }^{20}$.

Além disso, cabe aqui ressaltar que as condições introduzidas por estas companhias majestáticas nos territórios por si controlados, em parte, foram semelhantes às introduzidas nas outras campainhas arrendatárias coexistentes no centro do país e que eram submetidas às primeiras. As mais importantes foram a Companhia da Zambézia (1898) ${ }^{21}$, a Companhia do Borror (1904), a Companhia do Luabo (1904) e a Societé Du Madal (1906), a Sena Sugar States

${ }^{17}$ A 20 de agosto de 1907, a quando da visita oficial do príncipe herdeiro, Luís Filipe, este trazia o decreto real que elevava Beira ao estatuto de cidade. Inclusive, foi através do cognome do príncipe ("Príncipe da Beira") que a povoação foi renomeada - anteriormente denominava-se Chiveve (LISEGANG, 1972).

${ }^{18}$ Nos seus primeiros anos de atividade, a Companhia de Moçambique procurou dotar o seu território de infraestruturas e quadros administrativos que favorecessem o investimento econômico. Recorreram a sub concessões para as áreas da segurança e da política fiscal e a Companhia teve nos seus poderes a autoridade para explorar a mão-de-obra nativa através do sistema de trabalho forçado existente em Moçambique (NEWITT, 1987).

${ }^{19}$ Cecil John Rhodes (1853-1902) foi um homem de negócios britânico. Foi responsável pelo projeto de construção do caminho-de-ferro "estrada de ferro" que ligaria o Cairo, no Egito, ao Cabo, na África do Sul, nunca realizado. No entanto, os sucessos iniciais da Companhia entravam em conflito com os interesses britânicos na região e, em particular, com a empresa rival de Cecil Rhodes, a British South Africa Company (BSAC). Esta tinha pretensões em estender as suas terras no interior da África austral até o litoral no canal de Moçambique. Tal fato desencadeou uma série de conflitos militares na região entre as duas empresas e conflitos diplomáticos entre os governos de Portugal e do Reino Unido. Como resultado final destas diligências, foi firmado entre os dois governos, a 11 de julho de 1891, um tratado que reconhecia as fronteiras coloniais de ambos os países. Outros termos do acordo determinavam que o governo português tivesse de facilitar as comunicações terrestres entre o litoral e as terras no interior sob a jurisdição britânica (MUHATE, 1989).

${ }^{20}$ Em 1892, iniciou-se a construção da ligação ferroviária entre a Beira (capital do território da Companhia) e o seu porto com a cidade fronteiriça, nas terras da BSAC, de Umtali (atual Mutare). Esta ferrovia começou a laborar em fevereiro de 1898. Um ano mais tarde foi continuada a sua ligação até a capital da colônia britânica, Salisbury (atual Harare). Esta foi de grande importância para as trocas comerciais entre as duas companhias majestáticas, servindo o porto da Beira como meio de escoar os produtos e matérias-primas produzidos no hinterland da colônia britânica. Outro componente da sua importância era o transporte de trabalhadores moçambicanos para as minas localizadas sob a jurisdição da BSAC (MENDES, 1989).

${ }^{21} \mathrm{~A}$ Companhia da Zambézia possuiu o estatuto de semi-majestática. Foi à primeira das companhias arrendatárias na colônia portuguesa de Moçambique e abrangia área maior do que a das outras companhias. Esta companhia não tinha privilégios porque era concessionária (ou arrendatária). Sua origem remonta à concessão feita pelo governo a Paiva de Andrada, que compreendia as minas de ouro da Zambézia, posses até então inexploradas pelo Estado. Em 1879, em Paris, constituiu-se a Sociedade dos Fundadores da Companhia da Zambézia. Assim sendo, a Companhia da Zambézia foi criada oficialmente em 25 de maio de 1892,com o investimento de capital inglês. Entre os seus principais setores de atuação estavam à indústria mineral, a agricultura e o desenvolvimento da navegação no rio Zambeze (ROSA, 1986). 
etc. $^{22}$

Essas companhias também se dedicaram a grandes plantações de monocultura para exportação que, por sua vez, causaram bastante influência sobre a transformação econômica e social. Porém, a agricultura praticada por estas Companhias majestáticas e arrendatárias era no sistema de produção em tecnologias intensivas, em trabalho com baixos salários e no apoio à administração colonial para o recrutamento da mão-de-obra. As Companhias, enquanto desenvolviam a monocultura agrícola, muitas delas faziam também a criação de gado bovino com dupla função. Primeiro, para a alimentação dos trabalhadores, segundo, para a fertilização das terras em sistema de rotação produtiva das parcelas ${ }^{23}$. Para acrescentar às características das Companhias, deve-se ainda conotar que elas possuíam redes comerciais no interior de Moçambique para a aquisição dos excedentes de produtos alimentares dos camponeses. O objetivo dessa rede comercial era o mesmo que da pecuária e as lojas tinham também a função de comercializar a produção camponesa dos produtos de exportação, associados com atividade das Companhias ${ }^{24}$.

Alguns historiadores definiram o regime destas novas companhias como uma forma moderna de feudalismo ${ }^{25}$. Um feudalismo improdutivo e ainda politicamente incessível devido aos métodos escravagistas de forçar o assalariamento e a obtenção de mão-de-obra em regime de semi-escravidão, de formas a obter receitas para o Estado ou para as companhias. Abusou continuamente a população, as quais reagiam com contínuas revoltas ou com passividade frente

22 Em 1913, dos cerca de nove milhões de hectares da Zambézia, 5,4 milhões eram administrados pelos arrendatários, sendo os remanescentes 3,6 milhões a "reserva" do Estado. No entanto, a área total ocupada pelas plantações correspondia apenas a $0,5 \%$ da área arrendada (em 1924, este número sobe para 0,7\%). Isto pode ser explicado por estas culturas (coqueiro, sisal, algodão e cana-sacarina) exigirem muita mão-de-obra e as companhias não estarem interessadas em investir em maquinaria, uma vez que a população era excedentária e os salários exíguos. Além disso, as plantações reservavam sempre uma área para culturas alimentares, para evitar custos adicionais em alimentação dos trabalhadores. Esta política assegurava um lucro considerável. As plantações, no entanto, não eram a única fonte de rendimento das Companhias, pois algumas se dedicavam igualmente à exportação de mão-de-obra para o estrangeiro A Empresa Agrícola de Lugela tenha enviado moçambicanos para São Tome, nas plantações, bem como para trabalharem nas minas do Transvaal, na África do Sul (MOSCA, 2005).

${ }^{23}$ Ver. COVANE, Luís António. Agricultura colona, comércio rural e trabalho migratório no vale do Limpopo, 1900-1950. III Reunião Internacional de História de África. Lisboa, Centro de Estudos de História e Cartografia Antiga, Instituto de Investigação Científica Tropical, 2000.

${ }^{24}$ Ver, especialmente: MENDES, Rui. A cidade colonial e a estruturação do território em Moçambique: a evolução urbana de Lourenço Marques/Maputo, Beira, Nampula e Porto Amélia/Pemba. Tese (Doutorado em Geografia). Faculdade de Letras da Universidade de Porto. Porto, 2011; MUHATE, Isaias. Alguns aspetos do retrato histórico e perspectiva do porto da Beira. In: Arquivo Histórico de Moçambique. Cidade da Beira. Maputo: Arquivo Histórico de Moçambique. Boletim Semestral, ${ }^{\circ} 6$ especial. Outubro de 1989.

${ }^{25}$ Ver. MAZZEO, Antonio Carlos. Estado e Burguesia no Brasil: origens da autocracia burguesa. 3.ed. São Paulo: Boitempo, 2015. Mostra as vertentes matriciais mais significativas que nortearem as análises e as ações dos comunistas e a consagrada teoria do feudalismo. 
aos instrumentos utilizados para obrigá-las a trabalhar. Porém, estas companhias usaram várias formas, justificadas pelas dificuldades de recrutamento, como a obrigatoriedade do pagamento dos impostos em dinheiro, para persuadir os moçambicanos, além de terem também utilizado o trabalho forçado ${ }^{26}$.

As companhias eram simultaneamente, de um lado, fortes aliados do governo, mas por outro lado, introduziam elementos de conflito, sobretudo no relacionamento com as leis e regulamentos do trabalho. Mas como possibilitavam uma forma de colonização efetiva naqueles momentos em que Portugal de mostrava grande dificuldade de provar às outras potências coloniais a capacidade de ocupação dos territórios, freqüentemente os portugueses ignoravam ou não cumpriam a legislação do trabalho, os salários, as horas da jornada e, em muitos casos, havia violação nos procedimentos de recrutamento ${ }^{27}$.

A política colonial portuguesa no centro e norte de Moçambique, desde os anos 1880, não estava aberta a um campo de manobras para exploração e acumulação direta e mais rápida, o que foi possível só a partir dos anos 1926, com o golpe militar em 26 de maio. No entanto, importante ressaltar que foram promulgadas leis que revelaram a intenção do novo regime de estreitar as relações entre a colônia e a metrópole, corrigindo a fraqueza das relações econômicas existentes, assim como, se procurou meios para assegurar à pequena indústria têxtil portuguesa com o fornecimento regular da matéria-prima a preços baixos e em conformidade com o princípio de estabelecimento do controle direto do nível da produção ${ }^{28}$.

O governo português atuou em relação à produção do algodão, promulgando leis que estabeleciam normas do sistema produtivo dos camponeses quanto ao algodão. Segundo esta lei, de novembro de 1926, que vigorou até 1961, o governo faria concessões de grandes áreas a companhias concessionárias que se comprometessem a erguer uma fábrica de descaroçamento e um armazém em cada zona. Além disso, o governo tinha a função de divulgar e impor a cultura,

\footnotetext{
${ }^{26}$ Ver. CAPELA, José. Moçambique pela sua história. Porto: CEAUP. (Edições eletrônicas), 2010.

27 Ver. CAPELA, José. O Imposto de Palhota e a Introdução do Modo de Produção Capitalista nas Colônias - As Idéias Coloniais de Marcelo Caetano - Legislação do Trabalho nas Colônias nos Anos 60. Porto: Afrontamento. 1777.

${ }^{28}$ Os camponeses nativos passavam por uma obrigatoriedade forçada de cultivarem produtos de rendimento, como o algodão em todo o país, mas, principalmente ao Norte, produziam para o mercado com uma diferença importante em relação ao sul e centro, o que teve como conseqüência a transformação do campesinato dessa zona de pequenos produtores de mercadorias, especialmente através da introdução do algodão e da captação dos excedentes através da rede comercial. O norte comercializou uma produção total de cerca de 70 por cento, realizada pelos camponeses. Assim sendo, foi no centro onde estavam localizadas as grandes plantações, onde aproximadamente 58 por cento da produção mercantil eram realizada pelas companhias (HEGES, 1993)
} 
distribuir sementes à população camponesa, fornecer insumos, comercializar a produção, descaroçar para a exportação da fibra e controlar os camponeses. ${ }^{29}$ Outras ações do novo governo contribuíram para reforçar as posições da burguesia portuguesa e inglesa em Moçambique. Por exemplo, pouco depois do golpe, Portugal concedeu um grande empréstimo financeiro a Moçambique para cobrir dívidas externas. De fato, isto facilitou crescentes importações de vinho português, que aumentou de 3.082.315 de litros em 1926 para 6.758.601 de litros em 1930. Como corolário, abandonou-se o projeto de encontrar capitais ingleses para desenvolvimento do sul de Moçambique e assinou-se, em 1920, uma nova convenção com a África do Sul. Nela ficou acordado o repatriamento forçado dos migrantes moçambicanos que trabalhavam nas minas da África do Sul, que depois de um contrato de 18 meses, um sistema de pagamento diferido, focavam a regressar para receber cerca de metade dos salários do trabalhador a serem pago pelas minas ao governo de Moçambique em divisas, sendo o trabalhador reembolsado em escudos, no seu regresso ${ }^{30}$.

Para o efeito, nos anos de 1930, propôs-se a imposição de um controle mais direto e rigoroso sobre os recursos das colônias. Isto seria feito através de várias medidas, entre as quais se destaca a Lei Colônia, incorporada na Constituição portuguesa de1933. Essa medida prezava a unificação do território, o que significava a abolição do sistema de Companhias Majestáticas e arrendamento da terra, uniformizando assim o sistema administrativo do Estado colonial, que assumia diretamente a regulamentação do recrutamento e partilha da força de trabalho entre os diferentes setores econômicos, minas, plantações, trabalhos públicos, etc. Estas políticas tinham como propósito tornar as colônias eficientes na produção de matérias-primas necessárias para o desenvolvimento da indústria metropolitana. Para tal, o controle dos trabalhadores foi sistematizado com a instituição da Caderneta Indígena e dos cartões mensais, onde o doador de trabalho deveria registrar os dias de serviço efetivamente prestados ${ }^{31}$.

Em suma, outra medida para dinamizar a produção foi à tentativa de revitalizar as produções já existentes, como coqueiro, sisal e açúcar. No entanto, foram introduzidas outras novas produções, entre as quais se destacam o café e o algodão, em meados de 1930, e o chá, nos anos 1940. Houve também a difusão da cultura obrigatória de produção comercial (algodão e

\footnotetext{
${ }^{29}$ Ver. ROSA, Fernando. O Estado Novo nos Anos 30: 1928-1938, 1986.

${ }^{30}$ Ver. COVANE, Luís António. As Relações econômicas entre Moçambique e a África do Sul, 1850-1964; acordos e regulamentos principais. Maputo: Arquivo Histórico de Moçambique. 1989.

${ }^{31}$ Para mais informação sobre a política portuguesa neste período, ver. SALAZAR, Antonio de Oliveira. Discurso e notas políticas (3. ${ }^{\circ}$ Vol), 1943 e Textos de Salazar sobre política ultramarina, 1954.
} 
outros) e alimentar (arroz, milho, mapira), que só podiam ser vendidas às Companhias comerciais com monopólio em cada região. Outra medida foi o aperfeiçoamento do sistema de cobrança dos tributos, no qual o imposto de palhota substituiu o imposto de capitação, que, a partir de 1942, as mulheres também foram incluídas nos pagamentos ${ }^{32}$. Nesse período, Portugal moveu-se dedicadamente para a consolidação dos seus domínios, parte significante da emigração portuguesa foi enviada a Moçambique e foram criados fundos de investimentos consistentes para infra-estrutura em áreas urbanas e rurais, favorecendo o estabelecimento dos colonos portugueses em todos os domínios. Às classes médias - baixa nativa, principalmente das cidades, foi dirigida reformas de salários e a reorganização de serviços sociais. Assim como, a partir de meados dos anos cinquienta, foi permitida aos nativos a formação de cooperativas de produção e comercialização ${ }^{33}$.

\footnotetext{
${ }^{32}$ A evasão de imposto era punida com a prisão do infrator ou familiares, que eram submetidos ao trabalho forçado. Porém, todos os nativos maiores de 16 anos que não conseguissem mostrar que produziam as quantidades determinadas eram recrutados para o trabalho forçado ou contratado em setores públicos, minas, plantações, fazendas agrícolas de colonos, durante, pelo menos, seis meses por ano. As infrações às obrigações eram punidas com trabalho, obrigatoriedades, trabalho correcional, serviço militar e deportação para as plantações de cacau de São Tomé (MOSCA, 2005).

${ }^{33}$ Ver. FREIRE DE ANDRADE, Alfredo. Trabalho indígena e as colônias portuguesas - A escravatura e a sociedade das Nações. In: Boletim de Agência Geral das Colônias. Lisboa: Agência Geral das Colônias, n 16, outubro 1926.
} 


\section{II-CAPÍTULO \\ Organização da Econômica no Sul de Moçambique}

O segundo capítulo, sob o título, organização econômica no sul de Moçambique, tem como objetivo mencionar como as políticas portuguesas de exploração se processou na zona sul de Moçambique. Pressupomos que facilita-nos a perceber mais adiante como a organização da economia colonial dificultaria o desenvolvimento do socialismo. Assim sendo, este capítulo esta subdividido em três partes: A primeira é denominada força de trabalho, procura apontar a influência da África do Sul na organização econômica de Moçambique, principalmente nos acordos de fornecimento de serviços e mão de obra assinado entre os dois países.

A segunda parte, com o tema, Os colonatos agrícolas, tem como objetivo de evidenciar a importância dos colonatos na organização da economia colonial e a sua ligação a possibilidade de escoamento da produção agrícola. A terceira com o tema, Indústria Principiante, mostrar quais foram às formas de produção industrial que emergiram no período, é, no entanto, importante compreender que elas passaram a estar integradas na economia de Moçambique durante o socialismo.

\subsection{Força de Trabalho}

Este tópico procura também mostrar a influência da África do Sul na organização econômica do sul de Moçambique, principalmente a partir dos acordos de tráfego entre os dois países. Pressupomos que facilita-nos a perceber mais adiante como a organização da economia colonial dificultaria o desenvolvimento do socialismo. Já que o novo governo socialista teve como base esta mesma economia para o seu projeto de socialização de Moçambique. Isto é, na partes sul do rio Save, principalmente nas províncias de Maputo, Gaza e Inhambane ${ }^{34}$, a ocupação colonial se deu com base no sistema organizacional centrado na dinâmica do desenvolvimento capitalista, tendo como orientação principal as relações com a África do Sul. Nesses territórios, inclusive, nos finais do século XIX e princípios do século XX, foram

\footnotetext{
${ }^{34}$ A província nortenha de Nampula e algumas zonas dos prazos da Coroa na Zambézia (por exemplo, Milange, Ile, Gilé e Alto Molócue) ficaram sob a administração direta do estado português (ROCHA, 1985).
} 
realizadas inúmeras convenções sobre o trabalho migratório ${ }^{35}$.

Foram assinados acordos entre a indústria mineira sul-africana, em crescente, e o governo português, segundo os quais, o recrutamento seria realizado por uma empresa criada pela Câmara das Minas (Chamber of Mines) em 1902, a célebre WNLA (Witwatersrand Native Labour Association). Essa empresa possuía escritórios em vários pontos ao sul do país e teve um monopólio no recrutamento de trabalhadores que durou até 1966, momento em que a administração portuguesa incentivou a criação de empresas privadas de interesses portugueses no recrutamento $^{36}$.

A WNLA assinou vários acordos com o governo português para regulamentarem o recrutamento de trabalhadores moçambicanos ${ }^{37}$. Embora a WNELA tenha iniciado suas ações no ano de 1902, a regulamentação para o trabalho migratório tem seu início no ano de 1897 . Em 1901, foi assinado um acordo revogado na Convenção de Abril de 1909, entre Moçambique e África do Sul, que foi o primeiro acordo formal de fornecimento de mão-de-obra para a indústria mineira sul-africana, depois se celebraram outro, como o de 11 de Setembro de 1928, com o título de "Acordo sobre a Emigração de Nativos de Moçambique para Transval". Esse acordo celebrou-se num momento em que o regime fascista era implantado em Portugal, supostamente a sua pretensão era uma orientação nacionalista em defesa do uso dos territórios coloniais e dos seus recursos para o beneficio de Portugal, incluindo naturalmente a mão-de-obra barata, em favor dos colonos e da indústria portuguesas ${ }^{38}$.

Portanto, nos seus discursos contra a situação de desnacionalização das colônias, Salazar não tirou a concorrência das minas e dos proprietários coloniais do Sul do país pela procura de mão-de-obra e optou por manter a aliança com o capital mineiro sul-africano e, conseqüentemente, não só conservou, mas desenvolveu o sistema de trabalho migratório, em total contradição com os interesses dos setores capitalistas sul-africanos. Assim sendo, o equilíbrio das contas da colônia prevaleceu sobre os interesses dos colonos. Nessa perspectiva, os colonos não modificaram o essencial nos contratos, em continuidade ao projeto de exploração

\footnotetext{
${ }^{35}$ Os acordos se mantiveram em vigor mesmo depois da Independência em 1975, cujas recomendações deliberavam que tais províncias assumiriam o papel de reservas de mão-de-obra para a República Sul Africana.

${ }^{36}$ Ver. CENTRO DE ESTUDOS AFRICANOS. O mineiro Moçambicano: estudos sobre a expansão da mão de obra em Inhambane, 1998.

${ }^{37}$ Os acordos se mantiveram em vigor mesmo depois da Independência em 1975, cujas recomendações deliberavam que tais províncias assumiriam o papel de reservas de mão-de-obra para a República Sul Africana (CENTRO DE ESTUDOS AFRICANOS, 1998).

${ }^{38}$ Ver. MOSCA, João. Economia de Moçambique, Século XX. Lisboa: Editora Instituto Piaget, 2005.
} 
da mão-de-obra. Um dado relevante é que o Estado português ainda permitiu o recrutamento de 65.000 a 100.000 trabalhadores moçambicanos pela associação mineira do Transval ${ }^{39}$.

Ainda a respeito dessa exploração da mão de obra, o Estado português recebia uma parte do salário dos mineiros, que, por sua vez, era transferido para Moçambique em forma de ouro a preço fixo, sendo depois deduzidos os impostos e pagos aos trabalhadores como um seguro social em moeda local após o seu regresso. Este processo se concretizava depois dos trabalhadores regressarem obrigatoriamente a Moçambique para terem seis meses de descanso nas suas zonas de origem, depois de cumprirem os seus contratos de 12 meses, extensíveis por mais seis meses ${ }^{40}$. Porém, em 1930 a WNLA foi obrigada a pagar uma quantia negociável por cabeça recrutada pelo governo colonial, e também se comprometeu pagar diretamente ao governo moçambicano, em ouro, ao câmbio de 42,22 dólares/onça e cinqüenta por cento dos salários do tempo superior a 9 meses de trabalho dos migrantes. Além disso, o governo de Moçambique receberia dinheiros pelo número médio de emigrantes para trabalhar nas minas ${ }^{41}$. A migração no sul era de extrema importância para o país:

\section{TABELA1}

\section{O volume da força de trabalho no sul do país (percentagem da população ativa emigrada)}

\begin{tabular}{|c|c|c|c|}
\hline Anos & $\begin{array}{c}\text { Lourenço } \\
\text { Marques }\end{array}$ & Gaza & Inhambane \\
\hline 1940 & 17 & 19 & 26 \\
1950 & 23 & 19 & 24 \\
1960 & 14 & 17 & 15 \\
1970 & 24 & 17 & 16 \\
1975 & 24 & 19 & 14 \\
\hline
\end{tabular}

Fonte: CEA (1978, p. 90- 92).

Essa política de mão-de-obra na relação com a África do Sul constituía uma fonte importante de rendimentos em divisas para o colonialismo português, o que levou a maioria dos homens do sul de Moçambique com uma idade ativa a passarem grande parte da sua vida ativa

\footnotetext{
${ }^{39}$ Ver. SAÚTE, Nelson J.Pedro.Crônica de uma integração imperfeita: o caso da privatização da gestão dos portos e caminhos de ferro em Moçambique. 2010. 194f. Dissertação (Mestrado emSociologia) - Programa de PósGraduação em Sociologia, Faculdade de Filosofia, Letras e Ciência Humana da Universidade de São Paulo. São Paulo, 2010.

${ }^{40}$ Ver. MONDLANE, E. Lutar por Moçambique. Maputo: Nosso Chão, $1995.1^{\text {a }}$ edição moçambicana.

${ }^{41}$ Ver. CENTRO DE ESTUDOS AFRICANOS. O mineiro Moçambicano: estudos sobre a expansão da mão de obra em Inhambane. Maputo: Centro de Estudos Africano, 1998.
} 
no país vizinho, África do $\operatorname{Sul}^{42}$ e cerca de um terço da população desta zona passava mais de cinqüenta por cento da vida ativa na RAS (República da África do Sul). Apenas dez por cento dos moçambicanos ao sul do rio Save não dependiam dos contratos referentes ao deslocamento para esse país ${ }^{43}$.

É certo que até meados de 1960 emigraram para África do Sul e Rodésia do Sul cerca de 400.000 trabalhadores moçambicanos. Esses países constituíam, de fato, uma alternativa para enquadramento da mão-de-obra moçambicana e uma das principais fontes de receitas e divisas para o governo colonial. Só para elucidar a dependência, o orçamento de 1961 previa uma receita total de 6.300.000 de escudos (90 milhões de libras), e deste montante, 1.200 .000 (cerca de 20\% do valor) seriam provenientes das exportações de mão-de-obra ${ }^{44}$. Portugal recebia da África do Sul cerca de um bilhão de escudos em divisas, produto de taxas e salários dos trabalhadores e receitas dos portos e caminhos de ferro de Lourenço Marques, utilizadas pela África do Sul como contrapartida de venda de mão-de-obra ${ }^{45}$. Como mostra a tabela, dos dados estatísticos dos movimentos dos mineiros moçambicanos para África do Sul.

\section{TABELA 2.}

Emigração para as minas da África do Sul (em milhares)

\begin{tabular}{|c|c|c|c|c|c|c|}
\hline Anos $^{46}$ & Total & Moçambique & $\begin{array}{c}\text { Percentagem de } \\
\text { Moçambique }\end{array}$ & RAS & $\begin{array}{c}\text { Percentagem da } \\
\text { RAS }\end{array}$ & Outros \\
\hline 1931 & 226 & 73,9 & 32,7 & 112,5 & 49,6 & 39,6 \\
1939 & 323 & 81,3 & 25,2 & 155 & 48 & 86,7 \\
1951 & 306 & 106 & 34,6 & 108 & 35,3 & 92 \\
1960 & 396,7 & 95 & 23,9 & 150 & 37,8 & 151,7 \\
1970 & 401 & 113 & 28,2 & 96,9 & 24,2 & 191,1 \\
1975 & 393 & 79 & 16,5 & 170 & 43,3 & 144 \\
\hline
\end{tabular}

Fonte: CEA, O mineiro moçambicano, p.26.

Nos acordos relativos à questão da estrada de ferro e Relações Comerciais entre a Colônia de Moçambique e a África do Sul, foi definido que em contrapartida esse último país se

\footnotetext{
42 Ver. BELLUCCI, B. Economia Contempoânea em Moçambique: Sociedade Linhageira, Colonialismo, Socialismo, Liberalismo, 2007.

${ }^{43}$ Ver. CENTRO DE ESTUDOS AFRICANOS. A Estrutura Econômica no Fim do Período Colonial. Maputo: Centro de Estudos Africano, 1985.

${ }^{44}$ Ver. BELLUCCI, B. Tem, Mas Acabou Economia Contempoânea em Moçambique, 2005.

${ }^{45}$ Ver. ANDERSON, Perry. Portugal e o fim do ultra nacionalismo. Rio de Janeiro: Ed. Civilização Brasileira, 1966.

${ }^{46}$ A fonte não possui dados de 1930, 1940 e 1950.
} 
comprometeria a fazer transitar pelo porto de Lourenço Marques uma percentagem maior que 47,5 por cento das mercadorias da África do $\mathrm{Sul}^{47}$. Porém, o volume do tráfego nas estradas de mostrou claramente a vocação externa destes investimentos que se faziam presentes nas grandes participações inglesas e sul-africanas. Alinha férrea do Limpopo, ligando Lourenço Marques a Rosano Garcia (fronteira com África do Sul), já em 1908 tinha como receita total da exportação em relação a rede do CFLM (Caminho de Ferro de Lourenço Marques) uma receita total de $£ 297.427$, das quais $£ 30.688$ (10,3 \%), provenientes do tráfego interno e 266.739 (89,7\%) do tráfego combinado ${ }^{48}$.

Exposto à descrição parcial da influência do tráfego com a África do Sul, mostrando a dependência da organização econômica no sul de Moçambique, foi dependente deste país vizinho. Seguimos a nossa abordagem, procurado mostrar como a organização da economia no sul de Moçambique, foi organizada, em volta dos Colonatos que ligavam os objetivos sulafricanos e os interesses portugueses em Moçambique em que, posteriormente, fora as bases para o desenvolvimento pós-independência pelo seu potencial de mostrado abaixo.

\subsection{O Sul de Moçambique e os Colonatos}

Esse tópico procura mostrar como os colonatos foram uma importante forma de organização da economia colonial portuguesa, a exemplo, no sul de Moçambique, se procurava ligar a possibilidade de escoamento da produção agrícola, partindo dos acordos do tráfego com a África do Sul. Aproveitava as vias férias para responder os interesses portugueses em Moçambique, em que, posteriormente, foi uma das bases para o desenvolvimento econômico do governo pós-independência. Entretanto, a colonização do sul de Moçambique foi ainda caracterizada por uma maior presença de colonos nos setores de serviços (administração pública, portos e caminho de ferro) e na agricultura ${ }^{49}$.

Pequenos agricultores instalaram-se depois dos anos 1930 nas periferias das cidades,

\footnotetext{
${ }^{47}$ Ver. ROCHA, Aurélio.Lourenço Marques: classe e raça na formação da classe trabalhadora. O caso do setor ferroportuária de Lourenço Marques, 1890-1910. Maputo: Universidade Eduardo Mondlane, 1985.

${ }^{48}$ Essa receita em 1973 distribuiu-se por 165 mil contos (11\%) do tráfego de Moçambique, 339 mil contos (23\%) da África do Sul, 833 mil (57\%) da Rodésia, 85 mil contos (6\%) da Suazilândia e 47 mil contos (3\%) do Malawi (NEVES, 1991).

${ }^{49}$ Sobre a evolução da população colona ver, MUNSLOW, B. Dinâmica demográfica e suas implicações em Moçambique. Maputo: Centro de Pesquisa em População e Saúde [Gazeta de População e Saúde n 02], 2014.
} 
principalmente de Lourenço Marques (atual Maputo - nos vales dos rios Incomati e Umbelúzi e em Moamba) e de João Belo (atual Xai-Xai - no vale do rio Limpopo e na Macia), concentrandose na produção de produtos frescos e na criação de bovinos (em regime extensivo em propriedades de milhares de hectares). As grandes explorações agrícolas neste período resumemse às plantações de citrinos ao arredorda capital e de açúcar no vale do rio Incomati (em Xinavane e Macie $)^{50}$. Também, houve a cultura do algodão, produzido em pequenos e médios lotes por colonos individuais, assim como produziam arroz no vale do Limpopo ${ }^{51}$. Suportados pela emigração a partir de Portugal, que teve um aumento significativo entre os anos 1920 e $196^{52}$ :

GRÁFICO. 1.

Evolução da população colona (em percentagem)

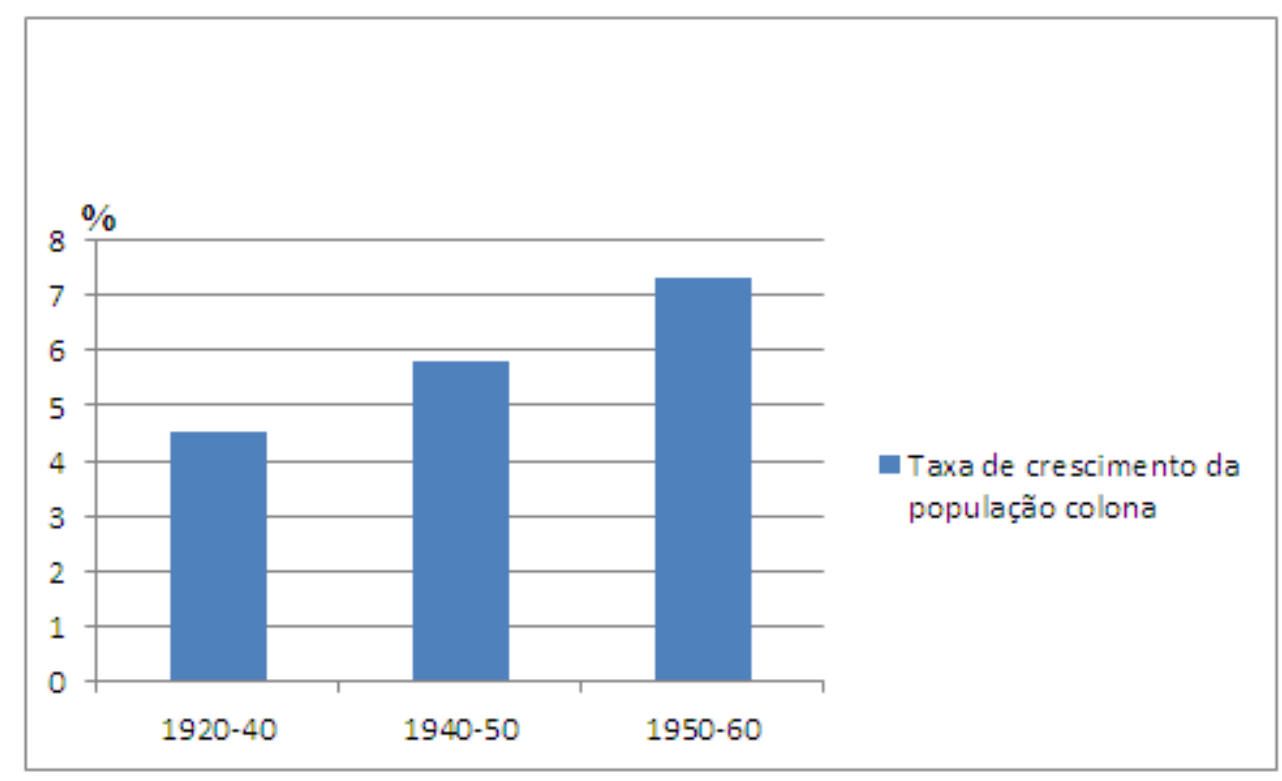

Fonte: Adapatado do Mac Wuyts(1980).

A imigração colona em Moçambique dirigiu-se, sobretudo, para o reforço do aparelho administrativo. O papel do Estado na economia direcionou-se para a produção de bens e serviços, forças de defesa e segurança. Para o comércio e agricultura, foi implantado colonatos ${ }^{53}$,

\footnotetext{
${ }^{50}$ Ver MOSCA, João.Economia de Moçambique, Século XX. Lisboa: Editora Instituto Piaget, 2005.

${ }^{51}$ Ver NEGRÃO, José. Cem Anos de Economia da Família Africana. Maputo, Promédia. 1991.

${ }^{52}$ Ver WUYTS, Marc. Economia Política do Colonialismo em Moçambique. Estudos Moçambicanos, Maputo, n. ${ }^{\circ}$ 1, Centro de Estudos Africanos, 1980.

${ }^{53}$ Em Moçambique colonial, o colonato consistiu em aldeias construídas por colonos portugueses em regiões rurais,
} 
que foram uma das ações mais importante da colonização do interior. Essa ação tinha vários objetivos específicos. Um deles era povoar Moçambique com portugueses como forma de reforçar a presença do regime no interior do território e criar alternativas para os cidadãos que emigravam de Portugal preferencialmente para a Europa e Américas. Outro objetivo era produzir alimentos que não integravam os sistemas de produção local para a alimentação da crescente população colonial. ${ }^{54}$

O maior do colonato foi localizado no sul de Moçambique, principalmente, na província de Gaza, no médio Limpopo, com sede no Chókwe (ex-vila Trigo de Morais), um investimento realizado no âmbito do I Plano de Fomento de 1953-1958 que tinha como objetivo orientar investimentos para os setores econômicos ${ }^{55}$. Esse plano direcionava a construção de obra de irrigação e de uma linha férrea Lourenço Marques-Rodésia do Sul, passando o rio Limpopo por cima da barragem de Macarretane, que servia de reservatório de água para os cerca de 22000 hectares de regadio ${ }^{56}$ É importante apontar que o objetivo central era a produção de arroz, que representava mais de $90 \%$ das áreas agrárias dos colonatos ${ }^{57}$. Como aponta os dados estatísticos agrícolas, abaixo apresentados:

\section{TABELA 3}

\section{Ocupação da terra para fins agrícolas, 1970 (hectares)}

\begin{tabular}{|c|c|c|c|c|c|c|c|}
\hline Setor & $\begin{array}{c}\text { Culturas } \\
\text { Anuais }\end{array}$ & Pousio & $\begin{array}{c}\text { Culturas } \\
\text { Permanentes }\end{array}$ & Pastagens & Florestas & Outras & Total \\
\hline Setor A & 196,3 & 94,8 & 223,8 & 1074,4 & 21,3 & 876,9 & 2487,5 \\
\hline Setor B & 2493,5 & 94,8 & 223,8 & 1074,4 & 21,3 & 876,9 & 2487,5 \\
\hline Total & 2689,8 & 94,8 & 223,8 & 1074,4 & 21,3 & 876,9 & 4981 \\
\hline Percentagem & 54 & 1,9 & 4,5 & 21,6 & 0,4 & 17,6 & 100 \\
\hline
\end{tabular}

Setor A: setor "moderno", capitalista, empresarial. Setor B: setor "tradicional" "familiar", de pequena escala, "informal", etc.. Fonte: MIA ${ }^{58}$, Estatísticas Agrícolas, 1970.

com apoio do governo colonial, com vista à ocupação efetiva do território, através do desenvolvimento agrícola e rural (MENDES, 2011).

${ }^{54}$ Ver SAÚTE, Nelson J. Pedro. Crônica de uma Integração Imperfeita: o caso da privatização da gestão dos portos e caminhos de ferro em Moçambique. 2010. 194f. Dissertação (Mestrado em Sociologia) - Programa de PósGraduação em Sociologia, Faculdade de Filosofia, Letras e Ciência Humana da Universidade de São Paulo. São Paulo, 2010.

${ }^{55}$ O segundo plano (1959-1961) visava estimular o investimento da burguesia nacional e o terceiro plano (19681973) atribuiu um papel fundamental á agricultura e á indústria transformadora.

${ }^{56} \mathrm{~A}$ barragem tinha a capacidade de armazenamento de 15 milhões de metros cúbicos de água.

${ }^{57}$ Ver. MISSÃO DE INQUÉRITO AGRÍCOLA1970. Lourenço Marques: Missão de Inquérito Agrícola, 1973.

58 A estatística oficial da época apenas considerava para o "setor B" as áreas ocupadas pelas culturas anuais e 
Moçambique possui uma superfície de $79938 \mathrm{Km}^{2}$, dos quais, de acordo com dados de 1970, cerca de $20000 \mathrm{Km}^{2}(18,8 \%)$ eram utilizados para fins agrícolas, havendo ainda aproximadamente $52873 \mathrm{Km}^{2}(66,2 \%)$ não ocupados, mas com boas condições de utilização agrícola. Apenas cerca de $10000 \mathrm{Km}^{2}$ não possuíam características para utilização agrícola, sendo os restantes $20000 \mathrm{Km}^{2}$ ocupados por rios, lagos, comunicação e assentamentos populacionais (cidades, vilas etc. ${ }^{59}$. Uma análise global deste número indica claramente a potencialidade agrícola e a não existência de restrições de terras aráveis. Como aponta a tabela abaixo:

TABELA 4.

Distribuição da terra, tamanhos das parcelas, 1970.

\begin{tabular}{|c|c|c|c|c|c|}
\hline $\begin{array}{c}\text { Dimensão das parcelas } \\
\text { (ha) }\end{array}$ & $\begin{array}{c}\text { Número de } \\
\text { parcelas }\end{array}$ & $\begin{array}{c}\text { Áreas } \\
\text { (ha) }\end{array}$ & $\begin{array}{c}\text { Percentagem } \\
\text { do "setor A" }\end{array}$ & $\begin{array}{c}\text { Percentagem } \\
\text { do "setor B" }\end{array}$ & $\begin{array}{c}\text { Áreas } \\
\text { Médias }\end{array}$ \\
\hline 0-10 & 1641158 & 2405789 & 0,2 & 99,8 & 1,5 \\
Percentagens de 0 a 10 ha & 99,3 & 48,3 & 0,2 & 99,8 & 1,5 \\
$11-50$ & 8729 & 152533 & 0,2 & 100 & 17,5 \\
$51-500$ & 1687 & 315979 & 0,2 & 100 & 1873 \\
$501-2.500$ & 555 & 592378 & 0,2 & 100 & 1067 \\
>2.500 & 219 & 153769 & 0,2 & 100 & 6912 \\
Percentagem com mais de & 0,01 & 30,4 & 0,2 & 100 & 6912 \\
\hline
\end{tabular}

Fonte: MIA, Estatística Agrícola, 1970.

As maiores parcelas localizavam-se no sul, nas atuais províncias de Gaza, Inhambane, e na província nortenha do Niassa. A existência de maiores parcelas cultivadas é justificada pelo fato de nestas províncias se verificarem camponeses sazonais que trabalhavam a terra impulsionada pelos fenômenos migratórios regionais, geralmente na época de maior necessidade de mão de obra procuravam outros trabalhos para aquisição de capitais para agrícola ${ }^{60}$. Assim sendo, maiores parcelas nas províncias do sul se devem também da socialização da tração animal

perenes. As superfícies destinadas a pastagens, pousio, árvores de frutas etc., não estão contempladas (MISSÃO DE INQUÉRITO AGRÍCOLA, 1973).

59 Ver. MISSÃO DE INQUÉRITO AGRÍCOLA, 1970. Lourenço Marques: Missão de Inquérito Agrícola, 1973.

${ }^{60}$ Ver. RITA-FERREIRA, António. O movimento migratório dos Trabalhadores entre Moçambique e a África do Sul. Lisboa, Junta de Investigação do ultramar, 1963. 
na preparação da terra como consequiência da aplicação do trabalho migratório. Igualmente existe justificação baseada nas formas de penetração de capital, do modelo de colonização e devido às propriedades de produção extensiva de gado bovino no sul ${ }^{61}$. Porem, apesar de ter como base a agricultura, nos colonatos, foram realizados investimentos em outras áreas, como a indústrias alimentares (descasque de arroz, laticínios, massas e pastas de tomate, tratamento da luzerna, entre outras) que mostraremos em seguida.

\subsection{As Formas de Produção Industrial}

Este terceiro tópico, procura mostrar as formas de produção industrial que emergiram no período, é, no entanto, importante compreender que elas estavam perfeitamente integradas na economia de Moçambique. Embora seja útil distinguir, para efeito de estudo, a forma de produção agrícola das formas de produção industrial que emergiram no período, é, no entanto, importante compreender que elas estavam perfeitamente integradas na economia colonial. Porém, nos meados do século XX, começava a surgir alguma dinâmica na indústria de bens de consumo e de embalagens, que foram se desenvolvendo nas três principais cidades (cidade de Lourenço Marques no sul de Moçambique (Atual província de Maputo), Beira no centro (na atual província de Sofala) e Nampula na província do mesmo nome no norte de Moçambique), e se estenderam numa rede comercial em direção ao interior, onde comercializavam bens de consumo, como por exemplo, o amendoim, o feijão e o milho. Não obstante, existiam importantes investimentos em infra-estruturas de comunicação terrestres, com uma contribuição aplausível da construção civil para o crescimento econômico no início dos anos $1960^{62}$.

A necessidade de imprimir uma nova dinâmica no crescimento das colônias levou a um deslocamento de grupos de capital português (sobretudo do financeiro) para Moçambique, esse processo se deu através do deslocamento de grupos econômicos importantes (também de capital não português), associado à indústria e ao setor financeiro. Estes grupos financeiros portugueses iniciaram as suas atividades associados com interesse no capital industrial.

\footnotetext{
${ }^{61}$ Ver. MOSCA, João . Economia de Moçambique, Século XX. Lisboa: Editora Instituto Piaget, 2005.

${ }^{62}$ Ver. RITA-FERREIRA, António. Evolução da mão de obra de remuneração no setor privado em Moçambique, desde 1950-1970. Lourenço Marques: Associação Industrial de Moçambique, 1971.
} 
O surgimento de bancos de capital não português (britânico e sul-africano) e de capitais dos colonos, que iniciava especialização das atividades financeiras, com bancos direcionados para diferentes áreas de atividades $^{63}$. O crescimento econômico possibilitou que os moçambicanos participassem em algumas atividades econômicas até então exclusivas para os colonos. Começaram a surgir, principalmente no meio rural, comerciantes, pequenas empresas de transporte e pequenas indústrias, principalmente moageiras. O Estado e as empresas públicas começaram a admitir moçambicanos para funções de maior importância ${ }^{64}$.

Apesar de a evolução econômica ter tido alterações estruturais pouco sensíveis, alguns de seus aspetos conjunturais influenciaram a economia após a independência em 1975. A evolução econômica aprofundou-se a partir da década dos anos 1960, isto devido ao aumento do investimento público, da política monetária expansiva e da aceleração da edificação de colonatos com o aumento da construção civil, sobretudo da habitação e de infra-estrutura. Cresceu também a indústria de substituição de importações, que teve um grande impulso devido ao crescimento rápido da população colona ${ }^{65}$.

Vale ainda salientar que, até a década de 1960, a respeito dos recursos minerais e da indústria, a prospecção de riquezas por meio desses seguimentos se revelou pouca ou nula, e a colônia parecia mesmo não produzir mais do que os modestos lucros provenientes da agricultura. No entanto, a descoberta nos anos 1960 de vários mineiros importantes, incluindo o carvão, a bauxita, os asbestos, o tântalo e o nióbio, além de modestas quantidades de ouro e cobre, e reservas de petróleo e gás natural, levou o governo português a abrandar as restrições aos investimentos estrangeiros nas "províncias ultramarinas". Contribuindo para o encorajamento de afluência massiva de capital estrangeiro a Moçambique ${ }^{66}$.

Assim sendo, há uma diferença nesses investimentos estrangeiros que começaram a surgir em Moçambique nos anos 1960 quanto à área de investimentos e as origens do capital. O investimento anterior ao período de 1960 limitava-se principalmente a projetos agrícolas e sua principal fonte de capital era a Grã-Bretanha. A Sena Sugar Estatais, por exemplo, era uma das companhias mais importantes desta fase inicial de investimentos, e tinha capital majoritariamente

\footnotetext{
63 Ver. LEITE, Joana. A formação da economia colonial em Moçambique. Pacto colonial e Industrialização: do colonialismo português às redes informais de submissão mercantil, 1930-74. Estudos de Desenvolvimento. África em Transição. UTL, ISEG, CESa: Lisboa, 2000.

${ }^{64}$ Ver. MOSCA, João . Economia de Moçambique, Século XX. Lisboa: Editora Instituto Piaget, 2005

65 Ibidem.

${ }^{66}$ Ver . MONDLANE, E. Lutar por Moçambique. Maputo: Nosso Chão, $1995.1^{\text {a }}$ edição moçambicana.
} 
britânica, sendo o maior produtor de açúcar de todas as colônias portuguesas: entre 1965 e 1966, contribuiu com 70\% da produção total; empregava 25000 trabalhadores africanos, e em 1967 apresentou uma receita de 1.400.000 libras, antes da dedução dos impostos ${ }^{67}$.

Os anos 1960, por outro lado, foi dominado pela África do Sul e Estado Unidos, embora a Grã-Bretanha, França e Japão também fossem importantes, assim como, países menores da Europa Ocidental, como Bélgica, Suécia e Suíça também tenham igualmente contribuído. Esses países operavam na extração de minerais, nas pequenas indústrias de processamento e de transformação, que se tornaram mais importantes que a produção agrícola. A prospecção de petróleo ocupou um lugar particularmente relevante: o Gulf Oil american iniciou a prospecção em 1953 e obteve direitos de concessão em 1958, desde então renovados várias vezes. Estas companhias obtiveram alguns sucessos no sul de Moçambique, incluindo a descoberta de gás natural em Pande, na província de Inhambane. Inclusive, a dimensão destas reservas é ainda desconhecida. Outra companhia americana que fez prospecção desde há vária anos foi a PanAmercan Internation Oil Corporation. Em 1967, ambas as companhias receberam novas concessões. A Gulf Oil, por exemplo, descobriu nova reserva de gás de 3000 milhões de metros cúbicos, próximo de Búzi (Provincia de Sofala) ${ }^{68}$.

Também em 1967 foram concedidos direitos de prospecção a três novas companhias americanas - Sunray Mozambique Oil Campany, Clark Mozambique Oil Company, e Skelly Mozambique Oil Company - e a um grupo de companhias sul-africanas e francesas. A concessão é feita inicialmente por três anos, durante os quais as despesas mínimas devem ser de 11 milhões de escudos nos primeiros anos, 35 milhões no segundo e 56 milhões no terceiro. As companhias pagam 3 milhões de escudos pela superfície arrendada durante os primeiros três anos, e após renovação do contrato, 200 escudos por quilômetro quadrado. O grupo francês e sul-africano é composto pela Anglo-American Corporation of South Africa, pela Société Nacionale des Pétroles d'Aquitaine, e pela Entreprise de Recherche et d'Activités Pétrolière. A concessão cobria uma área total de 14000 milhas quadradas, incluindo a região ao largo da costa. Durante os primeiros três anos, o investimento deveria ser de 140 milhões de escudos ${ }^{69}$.

A descoberta de jazigos de metais também atrairia fundos estrangeiros. Em 1967, foi descoberto próximo de Porto Amélia um grande jazigo de minério de ferro de alta qualidade, e os

\footnotetext{
${ }^{67}$ Ibidem.

${ }^{68}$ Ibidem.

${ }^{69}$ Ibidem.
} 
direitos para a sua exploração foram concedidos ao grupo japonês Sumitomo, que investiu 50 milhões de dólares americanos e tencionou construir uma linha férrea especial para Nacala (Província de Nampula). O minério tinha um teor de $60 \%$ de ferro, e as reservas foram então avaliadas em 360 milhões de toneladas. A produção prevista para os primeiros anos foi de cinco milhões de toneladas. Para o processamento parcial deste minério, estavam a serem construídos dois altos-fornos na Beira pela Sociedade Algodoeira de Fomento e pela Sher Company of Rhodesia. Outras descobertas da época incluíram: um jazigo de tantalita no distrito de Moçambique; um jazigo de minério de cobre, azurita e malaquita próximo de Nacala; ouro, perto de Vila Manica; e um novo filão de diamantes em Catuane, junto à fronteira com a África do $\mathrm{Sul}^{70}$. Esse interesse crescente do imperialismo pelas riquezas do país foi acompanhado por uma industrialização relativamente ${ }^{71}$.

No campo da indústria, os investimentos imperialistas se multiplicaram a um ritmo elevado $^{72}$. O destaque vai para a indústria de transformação, onde o investimento foi orientado principalmente para fábricas de processamento de produtos agrícolas ou fábricas de montagem de artigos importados já manufaturados. Exemplos típicos são a refinaria sul-africana de açúcar em construção perto da Beira, a fábrica de processamento de leite da Nestlé (Ninho) em Lourenço Marques e a fábrica de pneus American Fireston na Beira. Outros planos recentes incluíam o processamento da bauxita e a produção de amónia e de adubos químicos ${ }^{73}$.

Todo esse desenvolvimento da indústria de extração e transformação trouxe para Moçambique grande quantidade de capital estrangeiro e teve a capacidade, certamente, de aumentar o rendimento total do território. O desenvolvimento econômico resultante destes investimentos foi, contudo, extremamente superficial. Essencialmente, a natureza destes projetos foi ditada pelos interesses dos investidores e do governo português, e não pela necessidade de Moçambique. Entre1960 e o início da guerra em 1964, o número de instalações industriais, com um valor igual ou superior a 50 milhões de escudos, passou de 85 a 647. Entre 1967 e 1969, o ritmo médio de crescimento anual passou de 20\%, situando Moçambique entre os países de mais

\footnotetext{
${ }^{70}$ Ibidem.

${ }^{71}$ Ibidem.

72 O valor da produção industrial moçambicana do período dos anos 1960 colocava o país entre os oito países mais industrializados do continente e representava 4\% da produção industrial da África (MONDLANE, 1995).

${ }^{73}$ Quatro companhias - a firma sul-africana Frazer and Chalmers, as firmas francesas Sodeix e Socaitra e a empresa portuguesa Sociedade Química Geral de Moçambique - estavam envolvidas num projeto de construção de uma fábrica de adubos químicos perto de Lourenço Marques, que teria uma capacidade de produção de 170.000 toneladas e que necessitaria de um investimento de 250 milhões de escudos (MONDLANE, 1995).
} 
rápido crescimento industrial do continente ${ }^{74}$.

Apesar do volume dos investimentos, há três fatores importantes que impedem do desenvolvimento industrial trazer benefícios significativos para a maioria da população. Em primeiro lugar, porque estando a maioria das novas fábricas situadas nos principais centros urbanos - Beira e Lourenço Marques - qualquer melhoria nos salários e nas condições industriais que pudessem resultar da sua presença, teria efeitos extremamente localizados. Menos de $4 \%$ dos moçambicanos viviam nessas duas cidades, e mesmo a taxa de industrialização não foi suficiente para absorver o crescimento da força de trabalho urbano. A prosperidade crescente que se viu nessas cidades poderia afetar as zonas rurais vizinhas, mas num território vasto como Moçambique, com uma fraca rede de comunicação, não pode melhorar as condições de vida da grande maioria da população rural. A indústria de extração petrolífera, embora localizada no campo e espalhada por uma vasta área, também não pode beneficiar diretamente grande parte da população, essencialmente devido ao fato de necessitar de pouquíssima mão de obra local ${ }^{75}$.

O segundo fator relaciona-se com a utilização das receitas provenientes da nova indústria. Pode-se argumentar que a concentração do grande capital e a indústria de reduzida utilização da mão de obra poderiam ainda assim ter beneficiado todo o território através do aumento das receitas obtidas pelo governo. Uma parte das receitas não foi canalizada para os serviços sociais mais necessitados, mas sim, para a guerra: em 1967, a contribuição de Moçambique para as despesas das forças armadas portuguesas foi estipulada em 838 milhões de escudo, a serem retirados das receitas locais. Para poder cobrir tais despesas foi necessário reduzir outras despesas governamentais ${ }^{76}$.

Em terceiro lugar, em várias ocasiões o governo ofereceu condições tão favoráveis para atrair o investimento que acabou prejudicando bastante as receitas potenciais, autorizando a isenção de impostos durante longos períodos e a exportação total dos lucros obtidos. Em 1963,

\footnotetext{
${ }^{74}$ Ver. BELLUCCI, B. Economia Contempoânea em Moçambique: Sociedade Linhageira, Colonialismo, Socialismo, Liberalismo, 2007.

${ }^{75}$ De acordo com Pitcher (2003), entre 1962 e 1969, os investimentos nesse setor aumentaram em mais de $100 \%$. No entanto, $52,3 \%$ do investimento foram destinados a 180 unidades industriais que, se abasteciam o mercado interno, recebiam, comparativamente, apenas $47 \%$ dos investimentos. Tais investimentos beneficiaram, assim, o balanço de pagamento da zona de escudo e criaram melhores condições para financiamento da guerra colonial. Embora os investimentos tenham se duplicado no período em questão, o processo de industrialização traz em si o germe do desemprego, uma vez que o aumento do volume do investimento não produz postos de trabalho na mesma proporção, em função da necessidade do aumento da produtividade para que se realizasse a mais-valia relativa.

${ }^{76}$ Segundo Mosca (2005), em 1967 as despesas na defesa aumentaram 20\%, o orçamento para agricultura e floresta sofreu uma redução de $30 \%$, e o orçamento para obras públicas foi reduzido em $50 \%$.
} 
por exemplo, quando foi criada a Câmara de Comércio Luso-Sul-Africana em Johanesburgo para financiar novos empreendimentos em Moçambique, o Governador-Geral concordou, entre outras coisas, em conceder um período de dez anos de isenção de impostos às empresas estrangeiras. Em 1967, um relatório do South African Handels Institute salientou a necessidade de garantias quanto ao compartimento de capital e lucros e recomendou vantagens fiscais para as novas indústrias. As condições de investimento oferecidas foram com freqüência tão favorável para o investidor e ofereceram benefícios financeiros tão pequenos a Moçambique, que se tornou evidente que as concessões ao capital estrangeiro se destinaram mais a obter vantagens políticas do que a abrir caminho para um verdadeiro progresso econômico ${ }^{77}$.

\footnotetext{
${ }^{77}$ De acordo com Vieira (2010, p. 177), "pode-se afirmar que a luta pela igualdade se inseria como estratégia para garantir indiretamente e, há seu tempo, o objetivo da liberdade, da independência". O que sustenta posteriormente que experiência comum dos africanos já não era só o colonialismo, mas principalmente o subdesenvolvimento e o autoritarismo. Assim, as crises do modelo da continuidade, de críticas aos investimentos e ajudas inadequadas que favorecem a perpetuação da dependência na pobreza e na marginalização, significaram uma crise generalizada de legitimidade, na medida em que esta estava ligada à capacidade de realizar as promessas da independência (GENTILI, 1999).
} 


\section{III-CAPÍTULO}

\section{A Socialização das Zonas Libertadas}

O terceiro capítulo intitulado, socialização das zonas libertadas. Tem como objetivo expor o processo da socialização nas zonas libertadas. Pressupomos que facilita-nos a perceber os primeiros passos do desenvolvimento do modelo econômico socialista em Moçambique. Este capitulo, esta estruturado em dois tópicos: O primeiro denominado o surgimento das zonas Libertadas. Procura mostrar como foram surgindo zonas Libertadas em que foram se construindo as primeiras formas de organização econômica da FRELIMO em moldes socialista. O segundo tem como título, organização econômica das zonas Libertadas. Procura apontar como a organização econômica das "zonas libertadas”, estava estruturada atentando, principalmente, para a experiência das cooperativas.

\subsection{O surgimento das zonas Libertadas}

Este tópico tem como objetivo mostrar como foram surgindo zonas Libertadas em que foram se construindo as primeiras formas de organização econômica da FRELIMO em moldes socialista. O segundo tem como título, organização econômica das zonas Libertadas. Procura apontar como a organização econômica das "zonas libertadas", estava estruturada atentando, principalmente, para a experiência das cooperativas.

Nos na década dos anos 1960 o despertar das idéias nacionalistas ${ }^{78}$, combinado com as

\footnotetext{
${ }^{78}$ Dentro do debate de idéias na formação da FRELIMO, os nacionalistas defendiam de princípio as "idéias iniciais do socialismo para se ultrapassar o nacionalismo a favor do internacionalismo” (Vieira, 2010, p. 178). A ação destes nacionalistas, na verdade, começou de forma diferenciada, uma parte deles acreditava que as manifestações e a expressão popular, nas canções, músicas e danças, assim com, na literatura e na arte, era um meio fundamental de resistência anti-colonial. Essas disposições e discussão eram realizadas por intelectuais que muitas vezes eram estudantes ou funcionários e que, por sua vez, tinha conseguido se beneficiar do sistema de educação colonial, normalmente com o apoio e sacrifício das suas famílias. Esses, no sistema colonial, encontravam a discriminação racial no acesso aos postos de trabalho e nos salários, por isso, se viram na necessidade de defender e assegurara circulação de informações e análises que conscientizavam a luta ideológica contra o colonialismo. Podemos, ainda, concluir que na década de 1950, estes jovens intelectuais e artistas encontraram formas, mais ou menos sutís de criticar ao regime colonial português, e contribuíram para a evolução do conceito da nação moçambicana e da cultura nacional. Por outro lado, outros jovens na metrópole que se encontravam na casa dos estudantes do Império
} 
experiências das novas realidades se acreditava num rompimento político com o sistema colonial, acrescida dos sucessos alcançados por alguns movimentos de libertação e a africano, ausência de instituições políticas centralizadas, permitiram um desenvolvimento imediato de crise política de como grave de proporções ${ }^{79}$. Fato este que culminou com várias formas de luta pela independência. Foi inclusive na Tanzânia ${ }^{80}$ nos anos de 1960 que a Frente de Libertação de

português, no Salão da Tia Adresa ou na Casa de África em Lisboa, fundaram também o Centro de Estudos Africanos, um arsenal importante da consciência africana e regulamentadora das idéias dos movimentos de libertação. Nesse Centro de Estudos se discutia a economia, história, geografia e outras ciências. Muitos dos aspetos tratados eram ligados ao continente Africano. Ainda, a intelectualidade, que pequena dos países colonizados olhasse para a URSS e a China como faróis de amizade na escuridão do isolamento em que viviam. Porém, muitos conheciam e partilhavam as opções ideológicas socialistas, na procura de alternativas para responder a estabilidade econômica e política. Na Europa, tanto em Lisboa quanto em outros capitais, estudantes africanos continuaram suas atividades políticas e de combate ao racismo, inclusive no Centro de Estudos Africanos e na Casa dos Estudantes do Império Português, muitas vezes ajudados pelo Partido Comunista Português (PCP), também alvo da repressão Salazarista. O PCP foi o primeiro a reconhecer, em seu V Congresso, em 1957 "o direito incondicional dos países coloniais ao desenvolvimento independente", influenciando decisivamente na definição da consciência dos movimentos. Entre os estudantes africanos em Lisboa eram ilegalmente difundidos obras dos clássicos do marxismo-leninismo. Alguns estudantes freqüentavam mesmo o Centro de Estudos do Marxismo, organizado clandestinamente pelo PCP, nos arredores da Capital. Os nacionalistas pelos mecanismos do seu contacto conseguiram estabelecer ligações com os operários africanos que viviam na metrópole, com os marinheiros da frota comercial e com os estivadores. Com ajuda desses tornou-se possível garantir o envio de literatura clandestina proibida, principalmente através do Brasil, aos agrupamentos libertários. Entre os membros da FRELIMO, embora raros, alguns haviam estudado textos de Marx, de Engels, Lenine, Mao Tsé Tung, assim sendo, conheciam as representações teóricas para a situação vivida pelos moçambicanos. Existiam também as idéias inspiradoras para as intelectualidades de jovens moçambicanos como as ideias de personalidades respeitadas que pertencia, mas fileiras dos partidos comunistas, como no caso de Aime Cásaire, de Paul Vergés, de Kwane Krumah, defensor da união dos povos africanos, e do senegalês Leopold Senghor. E, também dirigentes nacionalistas como Houphöet Boigny, Modibo Keita e Sekou Touré e Patrice Lumumba .Esses no parlamento francês aliaram-se ao Partido Comunista Francês durante um largo período e até aos finais dos anos cinqüenta do século passado. Majoritariamente como estudantes africanos nas universidades européias, esses nacionalistas foram influenciados pelo Pan-africanismo, um movimento de mobilização, solidariedade fraterna e sensibilização pela causa africana defendida por "negros de ascendência africana das Antilhas Britânicas e dos Estados Unidos de América". Assim sendo, essas e outras idéias foram as que conscientizaram os moçambicanos a defenderem o socialismo para as colônias e o direito à independência. Esse processo foi, de fato, amadurecido, mas já tinha sua origem desde o momento que Portugal passa a sentir, nos anos 1960, a dificuldade ao enfrentar os nacionalistas que partiram para a luta armada com uma consciência socialista. A repercussão da dominação colonial como a que deu origem a comunidade territorial e criou as bases para uma coerência psicológica, fundada na experiência da descriminação, exploração e trabalho forçado e outros aspetos da dominação colonial. Assim sendo, "a natureza do colonialismo português (não preparou uma tradição estável para a independência), portanto, o Salazarismo era um regime político autoritário na metrópole como na África pelo que não houve tradução democrática nas colônias Africanas antes da súbita desagregação do império em 1974 - 1975" (MONDLANE,1995, p. 87).

${ }^{79}$ Exemplo da Rodeias do Sul e do Norte, Niassalândia, no Congo Belga.

${ }^{80}$ Segundo, Hedges (1993), na Tanganhica (atual Tanzânia), nos finais dos anos 1950, ainda protetorado britânico, as condições criadas para a independência formal deste país levou vários moçambicanos, com destaque para os trabalhadores que constituíram várias organizações. O destaque vai para duas organizações, a "TanganyikaMozambique Makonde Union" (União dos Macondes de Tanganhica e Moçambique), formado em 1958; e a "Makonde and Makua Zanzibar Union" (União dos Macondes e Makua no Zanzibar), formada em 1958 era inicialmente, vista como uma organização composta em moldes étnicos partindo da constituição dos seus membros. Além da assistência social em casamento e enterros, os seus objetivos eram semelhantes aos de uma associação de ajuda mutua progressiva, que vigorava entre muitas coisas a promoção de um ambiente de laços fraternais e amigáveis entre membros, fomentando o espírito de reconhecimento da tribo, partindo do encorajamento para a 
Moçambique (FRELIMO) se formou, em Dar-essalam, hoje capital da Tanzânia em 25 de junho de $1962^{81}$.

A FRELIMO no principio da sua formação, expressou no seu programa de governo no I Congresso em 1962, um estatuto com alguns dos pontos que se referiam diretamente à questão econômica. Entre esses pontos, os mais importantes argumentavam pela liquidação de todas as relações econômicas do tipo colonialista e imperialista, e que prevalecesse a reconstrução da economia e o desenvolvimento da produção. Com tais medidas econômicas o objetivo era transformar Moçambique, de um país colonial e subdesenvolvido para um país economicamente independente, industrial e desenvolvido; moderno, próspero e forte. Os objetivos também visavam defender os interesses de todo o povo de Moçambique, principalmente, das classes laboriosas, por meio da abolição do regime de trabalho forçado a partir da abolição dos acordos que rejeitam a migração dos trabalhadores moçambicanos para o exterior. Assim como, procuravam não somente o fim da discriminação racial ou de sexo, mas também, se pensava na existência de um salário-mínimo necessário para manter uma vida decente aos cidadãos, elevando assim, progressivamente o nível econômico do país ${ }^{82}$.

Por outro lado, a questão da terra era o centro das tensões no seio da FRELIMO. As discussões partiam do pressuposto de resolver qual era a melhor forma de exploração possível. E, de que forma a população gostaria de ver a restituição das terras expropriadas pelo colonialista.

educação acadêmica e técnica dos filhos dos membros da etnia. Segundo um relatório colonial, os inspiradores dessas organizações eram elementos católicos, apoiados pelos missionários instalados nos dois lados da fronteira, que viam na União um meio de lutar contra a expansão islâmica na região. O seu primeiro chefe era um carpinteiro moçambicano, da missão de Mikindani, que conseguiu muito adeptos entre os Macondes.

${ }^{81}$ A FRELIMO provém da fusão de três organizações que se encontraram na Tanzânia entre as organizações estava a 'União Democrática nacional de Moçambique' (UDENAMO), movimento criado sob a tutela Zimbabuiano, nos finais dos anos 1960. A UDENAMO foi a representante da Conferência das Organizações Nacionalistas das Coloniais Portuguesas, que ocorreu em Cassablancano (Marrocos) em Janeiro de 1961; esta conferência foi onde se sublinhou a necessidade da unidade e coordenação política, não só entre as organizações que participavam na conferência, como também as que não estavam presente. Comprometeu-se a lutar contra o colonialismo e o "neocolonialismo", A conferência enfatizou a necessidade de esclarecer o povo português, sobre a justiça da luta dos povos nas colônias, diferenciando, assim, os interesses do povo e os da burguesia portuguesa. Mas dois outros grupos aderiram à formação da FRELIMO. A “Mozambique African Nation Union"' (MANU) (em português, União Africana Nacional de Mozambique), fundado em Mombaça no Quénia, em Fervereiro de 1961. Ela era dirigida por respectivamente do Norte e do Centro, radicados nos países que os acolhiam. Esses emigrantes provinham de zonas precisas precárias do país e não estavam em condições de estenderem suas visões e projetos a níveis nacionais, devido à ilegalidade da sua ação em Moçambique, a inexperiência de ação clandestina e a consequiência da repressão. Em conseqüência da falta da experiência dos membros da MANU, muitos programas políticos e estratégias tendiam a refletir as suas vivências. A terceira organização que compôs a formação da FRELIMO foi a "União Nacional Africana de Moçambique Independente" (UNAMI), fundado em 1961 sob proteção da Niassalândia (atual Malawi). Este grupo foi liderado por Baltazar da Costa Chagongae que agrupava um pequeno grupo de amigos de naturais de Moatize (na província mineradora de Tete) (CAU, 2011).

${ }^{82}$ De acordo com Bellucci (2007). 
Nesse sentido, a questão da gestão seria uma permanente fonte de conflito, existiam aqueles que apontavam para a valorização dos produtores camponeses organizados em cooperativas e os apologistas da estatização, que apoiavam a centralização dos recursos em amplas unidades de produção controladas pelo poder público ${ }^{83}$.

Ao reivindicarem a independência, a FRELIMO provocou uma grave crise na estrutura colonial proporcionado pela adoção da luta armada para a libertação nacional, iniciada em $1964^{84}$. Contudo, as tensões, tanto no campo individual quanto na sociedade, permitiu que os nacionalistas vislumbrassem a necessidade do aprofundamento da reflexão da melhoria na sociedade a partir da teoria marxista ${ }^{85}$. Em uma breve descrição de alguns dos dirigentes da FRELIMO, revela o conhecimento das várias organizações políticas e para política em que eles estavam integrados ${ }^{86}$.

A independência e a libertação da opressão econômica foi um dos principais fatores para a organização da luta armada contra Portugal. O avanço da guerra para áreas onde a FRELIMO se viu necessitada a adotar uma nova estratégia de gestão das zonas em que passaram a controlar, prefigurando o vazio deixado pelo sistema colonial ${ }^{87}$. Nestas zonas a FRELIMO ensaiou as estruturas políticas, de produção, distribuição e comércio, serviços sociais, dentro de

\footnotetext{
83 Para mais informações sobre os camponeses em Moçambique, ver, WUYTS, Marc "Economia Política do Colonialismo em Moçambique, 1980. "Camponeses e Economia Rural em Moçambique, 1978. VALÁ, Salim. Desenvolvimento rural em Moçambique. Um desafio ao nosso alcance. Maputo, 2009. SERRA, Carlos, Como a Penetração Estrangeira Transformou o Modelo de Produção dos Camponeses em Moçambique, 1986. ISAACMAN, Allen "Camponeses, trabalho e processo de trabalho. O cultivo forçado de algodão em Moçambique colonial (1938-1961)”, 1991.

${ }^{84}$ Para ais informações sobre este período ver, THOMAZ, Omar. "Raça", nação e status: histórias de guerra e "relações raciais" em Moçambique, 2006; Valdemir Zaparoni. Entre narros e mulungos; colonialismo e paisagem social em Lourenço Marques c. 1890 e 1940. 1998; Monhés, Baneanes, Chinas e Afromometanos: colonialismo e racismo em Lourenço Marques, Moçambique, 1890-1940. 2000; “As 'Escravas Perpétuas' \& o 'Ensino Prático': Raça, Gênero e Educação no Moçambique Colonial, 1910-1930”. 2002.

${ }^{85}$ Ver. Hodge (2002).

${ }^{86}$ De acordo com Mondlane (1995), o Vice Presidente, Reverendo Urias Simango, era um pastor Protestante da região da Beira (no centro de Moçambique) que esteve envolvido em associação de ajuda mútua e que foi o chefe da UDENAMO. Também das associações de ajuda mútua veio Silériono Nugu, mas tarde secretário da Administração da FRELIMO, e Samuel Dlakama, membro do Comitê Central. Das cooperativas de camponeses do norte de Moçambique veio Lázaro Kavandame, mais tarde Secretário Provincial de Cabo Delgado, e também Jonas Namushulua, além de vários outros. Ainda das associações de ajuda mútua de Lourenço Marques e Xai-Xai no sul de Moçambique veio o Mateus Muthemba, e Sharffudin M. Khan, que foi representantes da FRELIMO no Cairo e Estados Unidos. Marcelino dos Santos, mais tarde Secretário da FRELIMO para os Assuntos Externos e do Departamento de Assuntos Políticos, era um poeta de renome internacional. Esse, portanto, eram algumas lideranças contidas na FRELIMO.

87 Para informações sobre o grupo lingüístico Macondes, conferir, Eduardo da Conceição Medeiros. História de Cabo Delgado e do Niassa (c. 1836-1929). 1997, também conferir Yussuf Adam. Mueda 1917-1990: resistência, colonialismo, libertação e desenvolvimento, 1993; “A subversão no distrito de cabo delgado - 1950 - 1960 , segundo as fontes administrativas locais",1991.
} 
numa experiência democrática popular de base. Com apoio popular a FRELIMO em 1968 conseguiu sobreviver aos ataques do sistema colonial, criando amplas áreas libertadas em Niassa, Cabo Delgado e, depois, Tete ${ }^{88}$. Nas áreas que eram dominadas, sem a presença do ocupante estrangeiro impunha-se a implantação das novas estruturas das zonas libertadas ${ }^{89}$, havia, para tal, um recomeço da atividade produtiva, a instalação de estruturas democráticas e populares de poder, de serviços de educação e saúde e do comércio interno. Esse processo caracterizava os primeiros passos da edificação das zonas controladas pela FRELIMO $^{90}$.

Para manter a vida social das áreas libertadas pela FRELIMO na luta pela libertação do país. A organização das zonas libertadas resultou numa experiência econômica que posteriormente foi conduzido e orientado no partido, chamado assim de novas tendências do desenvolvente pós-independência ${ }^{91}$. Esta experiência era organizada abertamente, com a representatividade dos membros que provinham de todas as camadas da população sendo a maior parte deles, tal como a maioria da população, composta de camponeses ${ }^{92}$.

A vida econômica nas zonas libertadas era organizada de forma a que os produtores trabalhassem coletivamente em cooperativas de produção, o abastecimento rural e a extração dos excedentes produtivos eram realizados através de uma rede de lojas da FRELIMO, sob a direção das estruturas locais do partido. Neste processo de pensamento das novas formas de exploração com base no estabelecimento de cooperativas, foram desenvolvido departamento de Produção e

\footnotetext{
${ }^{88}$ De acordo com Gentil (1998), estas zonas, sobretudo são resultado do avanço dos guerrilheiros da FRELIMO em áreas que estavam sob o controle do sistema colonial, em que ficou sem comando administrativo, tendo que ser deliberado aos chefes locais e as lideranças partidárias essa função.

89 Às primeiras zonas libertadas surgem como resultado de quatro anos de guerra, um fruto da retirada das autoridades portuguesas em algumas áreas do norte de Moçambique, o que leva a FRELIMO a ser a construtora das novas possibilidades de auto-sustentação do povo presente nesta área. O movimento de libertação, pela conjuntura da guerra contra o exército europeu, fez uma "fuga para frente", elaborando um projeto na qual as diversificadas respostas culturais pudessem confluir. Não obstante, com uma população aglomerada em redor das bases da guerrilha ou em zonas próprias, considerando a situação da guerra, estas zonas foram um centro da difusão das ideais da FRELIMO, sobretudo, da causa da luta e a formas de luta. Nesses centros de discussão e debates se opinava, perguntava e discutia os esclarecimentos dos objetivos para a população. Porém, a vida administrativa estava organizada em aldeias chefiadas por uns comitês populares que eram eleitos por toda a população da aldeia, na para responder o vazio deixado pela retirada dos representantes do estado colonial. No entanto, procurava também responder a causa de alguns problemas práticos e o fato desses entraves não ter sido claramente previsto pela direção da FRELIMO (CABAÇO, 2007).

${ }_{90}$ Essas zonas libertadas, para a FRELIMO, ultrapassavam a noção da mera ausência de força militares e administrativa colonial, ou apenas um local de novo controle administrativo, essas zonas representavam uma conquista. Em Moçambique, ainda existiam regiões diversas em que ainda a presença colonial não se fazia sentir direitamente, a sua administração ou suas forças repressivas. Tiveram dificuldade em sobrevivência humana e materiais, as enormes dificuldades na comunicação terrestre não permitiram à administração colonial nem às empresas uma ocupação de algumas regiões dopais (VIEIRA, 2010).

${ }^{91}$ Segundo Bellucc, (2007).

${ }^{92}$ Para Eduardo Mondlane (1995).
} 
Comércio, que procurou orientar a produção agrícola no interior e venda no exterior dos excedentes comercializados pelos camponeses, sobretudo na Tanzânia ${ }^{93}$.

Para consolidação de um processo administrativo eficaz foi necessário gerar uma série de serviços, particularmente os de natureza comercial, pois o povo destas zonas continuava necessitando de tais serviços. Essa situação começou se verificando logo após as primeiras vitórias da guerra, o movimento se viu a ter de resolver uma série de responsabilidades administrativas que recaia sobre a sua direção ${ }^{94}$. Portanto, percebem-se aí as dificuldades enfrentadas pela FRELIMO para, em conjunto, organizar a tomada dos territórios a partir da luta armada, e, por outro lado, sistematizar um processo de administração das zonas libertadas.

Tais dificuldades e entraves da FRELIMO afirmam que a população que carecia de administração e de serviços públicos era de 800.000 pessoas. As necessidades eram em primeiro lugar, na satisfação das necessidades materiais, assegurando abastecimento em alimentação e fornecendo outros artigos importantes tais como vestuários, sabão e fósforos. Assim, mesmo depois de dois anos do inicio da luta de libertação nacional, os novos desafios passavam pela criação dos serviços e educação da população civil e militar ${ }^{95}$.

A reorganização das estruturas nas zonas libertadas foi realizada no ano de 1966, com a criação de umas estruturas embrionárias para o comércio, administração, saúde e educação, transformando o início do novo país Moçambique ${ }^{96}$. Porém, esta base da nova estrutura

\footnotetext{
${ }^{93}$ Ver Machel (1986).

${ }^{94}$ Neste momento se pensava apesar da sua incapacidade o governo colonial, fez face às necessidades sociais insatisfeitas, fortemente sentidas pela população (MONDLANE, 1995).

${ }^{95}$ Segundo Mondlane (1995), era preciso criar serviços de saúde e de educação, e organizar sistemas administrativos e judiciais. Portanto, os problemas foram se agravando durante algum tempo, em que a FRELIMO não estava preparada para a amplitude do trabalho a que enfrentava e, ainda para dificultar a empreitada, careciam de experiência na maioria das áreas. Tais problemas se tornariam mais graves, pois em algumas aldeias os camponeses por vezes deixavam de apoiar a FRELIMO e em alguns casos, inclusive, abandonavam também a região.

96 Ao longo prazo, conforme o avanço da guerra, os trabalhos deviam enquadrar os refugiados no exterior e reorientá-los no sentido de desenvolverem uma vida nas áreas libertadas, a fim de reconstruir as aldeias e participar na luta. Isto significaria uma ajuda na reinstalação do povo e a construção de novas zonas habitacionais, para que o povo pudesse tão rápido quanto possível ser de novo auto-suficiente. A FRELIMO, durante esse período de transição também criou o Departamento de Educação, a idéia era que tal departamento pudesse ser à base da qual o futuro de Moçambique independente dependia para formar novo cidadão que pudessem conduzir o destino do país ao desenvolvimento. Contudo, o objetivo desse departamento era reformular o sistema, porque o ensino colonial não servia para a FRELIMO por não explicar as necessidades de Moçambique. Organizou-se de início um processo de bolsas para cursos no estrangeiro. Posteriormente, nas áreas libertadas, passou-se a criar escolas e cursos de formação para apoiar a população no interior do país. O sucesso da guerra e os progressos alcançados nos primeiros dois anos após 1964 provocaram um rápido crescimento da estrutura política e administrativa. A FRELIMO desenvolveu face ás nova exigências, novos departamentos e os antigos foram alargando as atividades. $\mathrm{O}$ Departamento de Educação era tido como parte essencial do desenvolvimento da luta, compreendendo que o envolvimento e o apoio da população à medida que crescia, necessitava de um maior apoio à situaçã $0^{96}$. A
} 
emergente foi desenvolvida segundo o modelo característico da democracia une partidária, já que a FRELIMO, para além de ser a força motora da luta de libertação, constitui também o governo das áreas libertadas ${ }^{97}$

A estrutura básica das leis partidárias até 1962 não eram favoráveis a FRELIMO, pois essa não poderia exercer uma atividade político legal em Moçambique já que modelo estava voltado para organização clandestina ${ }^{98}$. Obviamente essa estrutura teve que passar por modificação para cumprir eficazmente a função de governo nas áreas que passaram para as mãos da FRELIMO. Portanto, durante um período, devido à clandestinidade das atividades da FRELIMO, uma pequena minoria da população, os mais politizados, se envolveram nas primeiras tarefas de organizar um Comitê Central, que foi capaz de estabelecer uma estrutura política no interior de Moçambique até em 1964. A estrutura centrada no Comitê Central trabalhava direitamente com o partido, com a força de libertação e como governo provisório, organizado em diversos departamentos ${ }^{99}$.

Para melhorar a organização do território nas zonas libertadas a FRELIMO realizou o Segundo Congresso em Julho de 1968, com a presença de delegados de todas as províncias do

importância do Departamento de Educação era uma especificidade para a FRELIMO, porque dela acreditava-se que o processo educacional dever-se-ia começa do zero, como nova história da participação da FRELIMO para a sociedade, criando não só novas estruturas, mas elaborando também novas matérias disciplinares. O esforço da FRELIMO na educação resumia-se na elevação do número de crianças negras com o ensino primário completo nas zonas libertadas, que aumentaram para cerca de 100 000, do que em todas as escolas oficiais da colônia, onde havia apenas cerca de 40 000, de acordo com as estatísticas ${ }^{96}$. Em 1970 havia apenas 50 africanos negros com diploma do ensino secundário. No entanto, essa situação se modificaria no período pós-independência, nos lugares sob o controle da FRELIMO havia mais estudantes negros no ensino secundário e que tivesse concluído o ensino superior do que em todos os estabelecimentos de ensino das zonas ocupadas pelo governo colonial português ao longo de todos os anos de dominação. O ideal transmitido por meio do sistema educacional era a necessidade de ser autosuficiente e ao mesmo tempo trabalhar juntos com os outros, compondo um bem comum ensinado através do trabalho prático e das aulas teóricas (MONDLANE, 1995).

${ }^{97}$ Ver. CHRISTIE apud MACAGNO (2005).

${ }^{98}$ Ver. I Congresso da FRELIMO (1962).

${ }^{99}$ Existia ainda o Departamento das Finanças, responsável pela administração dos fundos da organização, que eram fundos e recursos financeiros que provinham, em parte de Moçambique, através das quotas pagas pelos membros, dos nativos, contribuições e das receitas de exportação, e outra parte também provinda do estrangeiro, através de donativos de governos e organizações estrangeiras ou internacionais. Assim sendo, todas as atividades do partido eram financiadas por estes fundos. Outra repartição era o Departamento de Informação, Publicidades e Propaganda, preocupado em manter o povo moçambicano informado sobre o trabalho e objetivos da FRELIMO, e sobre a situação de Moçambique e a sua posição dentro do contexto mundial. Havia também um Departamento de Assuntos Sociais, ocupada em cuidar dos refugiados que tinham vindo de Moçambique para a Tanzânia. A função desse departamento era da distribuição dos produtos de primeira necessidade, adquirido pelos apoios vindos de diversos pontos do mundo para a manutenção da vida diária do grupo. Como conseqüência do início da guerra colonial, em 1964, este departamento estendeu as suas atividades para o interior de Moçambique, lidando com os problemas de deslocação de grande parte da população que foi obrigado abandonar sua povoação nativa devida a guerra (MONDLANE, 1995). 
país. Esses delegados que participaram do Congresso foram eleitos pelas pessoas que os representavam nas suas estruturas partidárias locais, que funcionam livremente nas zonas libertadas e secretamente nas áreas controladas pelos portugueses·. Nesse Congresso "houve, cautelas na definição dos postulados vividos ideologicamente, o que Ergô, chama de "surgimento de um primado postulado socialista tácito" (ERGÔ,1992, p. 41). Assim, procurou-se aglutinar a coexistência dos vários sistemas, cada uma adaptada às condições específicas prevalecente em cada localidade. Estas estruturas governamentais em cada zona libertada, por um lado necessitava de uma incorporação na nova estrutura política, tanto representado pelos lideres tradicionais, como pela nova estrutura do poder moderno. As decisões importantes no segundo Congresso foram tomadas de acordo com a composição da FRELIMO, que procurou conduzir a uma estrutura mais democrática e uma nova orientação política dando prioridade a organização do interior de Moçambique ${ }^{100}$.

Para estas zonas libertadas o segundo Congresso organizado pela FRELIMO, decidiu que administração das zonas libertadas tinha que ter em vista a realização do estabelecimento do poder popular. Com base na defesa e a promoção do desenvolvimento, o progresso econômico e social das populações, construiria as bases para o desenvolvimento da vitória da luta armada revolucionária ${ }^{101}$. Neste sentido, o desenvolvimento da produção revestiu-se de uma importância especial, a estratégia foi aplicar no desenvolvimento da agricultura, indústria e artesanato de acordo com o interesse da revolução popular. A concentração da população era justificada pela necessidade de comunicação e, por sua vez, devido à carência desses meios de comunicação e também pela escassez de recursos humanos qualitativos responsáveis para organização do território $^{102}$.

A ação de reorganização das estruturas econômicas deveria ser priorizada entre diversa

\footnotetext{
${ }^{100}$ Ver. II CONGRESSO DA FRELIMO (1968).

${ }^{101}$ Este congresso procurou o engajamento da população na luta de libertação, mostrando que estas aldeias tinham vários objetivos: um deles era a participação da população na guerra. Para proteger esta população e obter ajuda, a FRELIMO criou algumas milícias populares que faziam o trabalho de mobilizar as populações, velhos e jovens, mulheres, que não faziam parte das guerrilhas, devendo satisfazer as necessidades de produção, vigilância e defesa. Outro objetivo dessas milícias era de promover o voluntariado para o transporte de material e doente. A FRELIMO acreditava ser o reconhecimento e a participação de toda a população algo extremamente importante. Para a participação da mulher foi criado o destacamento feminino, cujas funções principais eram: mobilizar e organizar a população, recrutamento de jovens, a produção, o transporte e a proteção militar (MONDLANE,1995).

${ }^{102}$ Ver Samora Machel. FRELIMO: documentos fundamentales Del Frente de Libertación de Mozambique, 1973; Comité Central da FRELIMO, 1968.
} 
dificuldade e problemas que deveriam ser resolvidas ${ }^{103}$. A prioridade na organização de um sistema econômico que atentasse aos problemas internos de Moçambique era primordial, pois a atual organização econômica somente procurava satisfazer os interesses exclusivos da metrópole colonial. O fato de esses produtos primários terem mercados nos países aliados ao movimento libertário permitiu que a produção de oleaginosa fosse organizada pela FRELIMO em locais sob seu devido controle. Facilitando assim um maior controle dos produtos que eram trocados por alimentos, que garantia sobrevivência da população durante o período de fome. Para tanto, "a produção agrícola realizava-se em parcelas familiares, em cooperativas e nas parcelas da FRELIMO. Nessa fase, tanto os guerrilheiros, quanto a população contribuíram para a manutenção do trabalho ${ }^{104}$ existia uma dependência mútua entre a FRELIMO e a população que estas necessitavam da proteção e de abastecimento de produtos manufaturados essenciais (sal, açúcar, roupa, etc.) e o movimento de libertação necessitava da participação da população para o recrutamento de guerrilheiros, para desempenho de funções paramilitares e outras atividades ${ }^{105}$.

Em conjunto com produção estava a preocupação com o desenvolvimento do comércio, tanto interno como externo, dentro de uma coordenação entre todos os setores de atividades. A preocupação específica para FRELIMO era a de tentar interligar a produção e o comércio na tentativa de esforçar a diversificação da produção, introduzindo e generalizando a produção de horticulas. Esses esforços foram incentivados por uma melhoria nas técnicas agrícolas e introdução de outras técnicas novas, como a fertilização da terra pela utilização de adubos.

Essa estratégia de unir a produção e o comércio tinha como objetivo além do desenvolvimento da produção agrícola, também o incentivo na produção dos produtos que fossem úteis para o fabrico de artigos básicos como sabão, tecidos, etc. A idéia era a defesa da consolidação dos campos cultivados e do desenvolvimento da organização das cooperativas agrícolas, comerciais e industriais. Na concepção da FRELIMO, era primordial uma estratégia que visasse à distribuição de alimentos e vestuários ao povo, e a organização de serviços básicos de saúde para melhor servir a sociedade ${ }^{106}$.

\footnotetext{
${ }^{103}$ Para Mondlane (1995).

104 Ver. Mondlane (1995).

105 Conforme Casal, (1991) em 1971, o Comité Central da FRELIMO sublinhou que a ambição de prosperar individualmente e acumular riquezas era ilegal e também imoral mente, supostamente por usufruir de esforço dos outros para conquistar privilégios individuais. Tais fundamentos podem ser constatados em diversos textos e Notas de Estudo na qual Samora difundia a preocupação da FRELIMO em prevenir que nas condições de guerra se criassem condições para que uns enriquecessem à custa do esforço e sacrifício de muitos.

106 Segundo Vieira (2010), em 1977, no III Congresso os estatutos excluíam da candidatura a membros da
} 


\subsection{A Organização Econômica das Zonas Libertadas}

Este tópico tem com objetivo apontar como estavam organizada a economia do movimento de Libertação (Frente de Libertação de Moçambique -FRELIMO), nas zonas libertadas, atentando, principalmente, para a experiência das cooperativas organizadas nas zonas libertadas. Recordar que neste período entre os finais dos anos 1950 e principio dos anos 1960, Portugal procurava alcançar seus objetivos econômicos com a integração da economia do país com a das colônias. Este processo tardio de desenvolvimento teve como causa o fato da ditadura portuguesa intensificar o controle da vida econômica das colônias. Por meio de ações políticas o governo ultramarino decidiu unilateralmente alterar a constituição em 1951, declarando que Portugal era uma nação composta não só por Portugal, mas também por todas as suas possessões ultramarinas $^{107}$.

Ainda nos finais dos anos 1950, o governo colonial havia reduzido e, por fim, eliminado todas as contribuições financeiras de Portugal ao desenvolvimento das colônias, alegando que as colônias deveriam pagar as suas despesas com recursos próprios, de modo a que houvesse um equilíbrio no orçamento dos territórios ultramarinos e as receitas e as despesas fossem totalmente cobertas pelo orçamento do território ${ }^{108}$. A base do argumento partia do pressuposto de que havia uma situação econômica já constituída no território em relação ao mercado: Moçambique, fundamentalmente, servia de reserva de mão de obra para o mercado estrangeiro ${ }^{109}$. Foram estas e outras idéias que os nacionalistas moçambicanos lutavam contra ${ }^{110}$. Eles queriam a independência das colônias, visto que Portugal já não tinha mais condições política e financeira

FRELIMO, os latifundiários e capitalistas. No entanto, a legislação não retirou a propriedade privada da legalidade e dos direitos da pessoa.

107 Ver Vieira, 2012.

108 Portugal acreditava que com uma participação melhor no mercado os territórios ultramarinos poderiam além de custear suas despesas colaborar para o crescimento da Metrópole. Neste período ainda, os territórios ultramar foram obrigados a pagar os custos de manutenção de várias instituições políticas, econômicas e educacionais em Portugal metropolitano, tais como o Conselho Superior Ultramar, a Agência Geral do Ultramar, o Instituto de Medicina Tropical e o Centro de Estudos Ultramarinos (MOSCA, 2005).

${ }^{109}$ Como confere Bellucci, (2007), a participação do governo português no comercio ultramar era dois terços do orçamento dos órgãos não governamentais, tais como os conselhos de coordenação da exportação do algodão, cereais e café. Entre 1959 e 1967, a porcentagem anual dos investimentos não português nas colônias passou de $1 \%$ para $30 \%$, fazendo com que as colônias se tornassem um instrumento temporário para impedir o agravamento das contradições sociais em Portugal, fato também que permitia a sobrevivência do regime fascista português.

${ }^{110}$ Ver. MAZULA, Brazão. Educação, cultura e Ideologia em Moçambique, 1975-1985 (em busca de fundamentos filosófico-antropológicos). Tese de Doutorado. (História e Filosofia da Educação) - Faculdade da Educação da Universidade de São Paulo, 1993. 
para custear os gastos e manter a dominação.

Um fator importante a considerar foi que a guerra impôs novas necessidades alimentares principalmente para o exército, que não tinham condições de auto-suficientes. Num período, em que a economia de Moçambique possuía um conjunto de novas características que se reconfiguraram devido a guerra e a necessidade de crescimento e ajustes de base na sociedade. Internamente, havia uma pressão para fomentar a tentativa de uma maior integração das economias coloniais na economia metropolitana ${ }^{111}$. A evolução da economia nos últimos anos, durante a guerra colonial, teve alterações estruturais pouco sensíveis, mas aconteceram aspetos conjunturais e que influenciaram a economia após a independência ${ }^{112}$.

Devido à guerra os custos de realização de grandes empreendimentos aumentaram, com efeito, a FRELIMO sentiu a necessidade de boicotar os investimentos, atacando vias de comunicação para dificultar ou impedir a realização de alguns investimentos públicos importantes. O caso da Cabora Bassa foi um exemplo dessa estratégia ${ }^{113}$. Assim como os ataques à linha de alta-tensão de energia destinada à África do Sul. Em muitas outras zonas a articulação da economia e dos espaços foi dificultada ou mesmo impedida com conseqüência sobre a rentabilidade dos agentes econômica e sobre a eficiência do conjunto da economia. A emergência das zonas libertadas e os ataques às vias de comunicação importantes, como a linha férrea Beirra-Rodésia e Beira-Tete em Maotize, e a linha de Nacala e, também, em muitas estradas rodoviárias, ações que impossibilitaram a continuidade de algumas atividades econômicas no meio rural. Tais aspectos afetaram as funcionalidades entre os setores e espaços, entre a "economia tradicional" e a "economia moderna", entre o campo e a cidade e, em alguns casos, suportados pelas rupturas de comunicação, que introduziram graves distorções no funcionamento da economia.

\footnotetext{
${ }^{111}$ Ver. COVANE, Luís António. As Relações econômicas entre Moçambique e a África do Sul, 1850-1964; acordos e regulamentos principais, 1989.

112 Covane (2000), opção a partir da década dos anos 1960 foi aprofundar os investimentos públicos e a política monetária expansiva, acelerou-se também a edificação de "colonatos tampão", a construção civil, sobretudo da habitação e de infra-estrutura, cresceu e a indústria de substituição de importações como consequiência do rápido crescimento da população colona

${ }^{113}$ Cahora Bassa é uma barragem moçambicana construído durante o período colonial português) situa-se no Rio Zambeze, na província de Tete. É ainda a maior barragem em volume de betão construída em África e o maior empreendimento do Estado Português no antigo império. É atualmente o maior produtor de electricidade em Moçambique, com capacidade superior a 2000 megawatts, que abastece Moçambique (perto de 250MW), África do Sul (1100MW) e Zimbábue (400MW). Esta barragem, foi projetada no âmbito do Plano de Desenvolvimento do Vale do Zambeze, um projeto ambicioso de desenvolvimento daquela região, lançado pelo Estado português. A sua construção começou em 1969 e a segurança durante esta fase esteve garantida pelos Batalhões de Caçadores Páraquedistas portugueses 31 e 32 .
} 
Além disso, as represálias dos portugueses aos camponeses que fossem suspeitos de compartilhar uma simpatia pela FRELIMO levaram em muitas áreas a evacuação dos camponeses, para se instalaram em novas aldeias, onde a princípio foi preciso que a FRELIMO procura-se comida para alimentar os camponeses até as primeiras colheitas de novos campos ${ }^{114}$. Mas, com atividades desenvolvidas nestas áreas onde freqüentemente as culturas eram destruídas pela ação portuguesa, era necessário sensibilizar o povo para desbravarem mais terra para cultivar e a produzir mais comida ${ }^{115}$. Essa campanha foi tendo tanto sucesso que, apesar dos perigos e transtornos da guerra, nos finais dos anos 1960 se produziu mais comida e surgiu mais terra cultivada do que havia durante a administração colonial. Porém, o maior estímulo da produção resultou, sem dúvida, da abolição das companhias e do fato de pessoas tirarem proveito do seu próprio trabalho.

Nesse momento eram reinstaladas as cooperativas de produção no modelo socialista, uma prática de cooperativização diferente das já conhecidas em alguns locais de Moçambique durante a administração colonial em que tinha algumas cooperativas no Sul do país (especialmente em Zavala), onde majoritariamente, eram formados por alguns produtores agrícolas de pequena e media porte ${ }^{116}$. Também existiam no Centro do país, em Sena, por exemplo, existia uma cooperativa de produtores de algodão. Contudo, no Norte de Moçambique esse processo foi surgindo com maior força pela primeira vez nas zonas libertadas, embora já fossem conhecidas na província de Cabo Delgado, onde a Sociedade Algodoeira Africana

114 Para mais informações sobre a organização dos camponeses ver, DIREÇÃO DOS SERVIÇOS DE PLANEAMENTO E INTEGRAÇÃO ECONOMICA. III Plano de Fomento, 1966; IV Plano de Fomento, 1966; ENNES, António. O trabalho indígena e os créditos agrícolas, 1946.

${ }^{115}$ A comida e vestes fornecidas aos camponeses entre a década de 1960 e princípio de 1970, impulsionou ainda mais a consciencialização da exploração colonial e um sentimento de luta revolucionária contra o sistema capitalista a favor da opção ao socialismo. Em meio a um contexto de Guerra Fria, o processo revolucionário moçambicano se aproximou cada vez mais das ideais marxistas. Nesse contexto colonial e de Guerra Fria, os apoios econômicos se dividiam entre os capitalistas ocidentais que apoiavam o Governo colonial português e a Russia, China e outros países socialistas que apoiavam a FRELIMO. Por isso que, difundido de maneira geral, se pensou que a luta entre Portugal e Moçambique, pudesse ter sido percebida também coma uma luta entre o bloco capitalista e o bloco socialista. Apesar de tudo, a Guerra Fria, criou um equilíbrio pela estrutura das grandes potências, o que geralmente, abalou a transformação das ações sócio-políticas em Moçambique, e que, por sua vez, influenciaram ou motivaram os laços entre o bloco soviético e a FRELIMO contra o desenvolvimento do imperialismo. A participação da China ao lado do bloco socialista nos anos (1960 e 1970) possibilitou que os moçambicanos tivessem alternativas nas alianças internacionais em favor do socialismo. Entretanto, a grande participação da "linha maoista" teve um grande impacto na defesa socialista e na luta revolucionária. Assim sendo, a China mostrou aos nacionalistas como sua economia poderia ser sustentada pelos camponeses. Inovação esta que deu à via chinesa de construção do socialismo um caráter de verdadeiro movimento de massa, muito, mas democrático que o modelo soviético com um tratamento igualitário par todos os homens e mulheres (MACAGNO, 2009).

116 Ver. Estatudo-Tipo para as Cooperativas de Produção Agrária, 1971. 
Voluntária de Moçambique (SAAVM) foi o seu expoente máximo desde ano de $1958^{117}$.

Alguns responsáveis pelo progresso dessas cooperativas, posteriormente vieram a se integrar a FRELIMO. As cooperativas foram um dos fatores importantes no aumento da produtividade, associada ao trabalho do partido de aconselhar e encorajar a população, explicando as necessidades da luta, e distribuindo instrumentos essenciais para o cultivo da terra, como enxadas e catanas. As cooperativas foram controladas pelos comitês das cooperativas, com diversas funções em nível do governo local, e este sistema se alastrou rapidamente, e provavelmente foi um dos fatores de destaque no futuro governo local pós-independência. Em que foram surgindo em áreas onde em que não haviam antes de serem libertadas pela FRELIMO, bem, com, em áreas onde já havia o movimento cooperativo antes da luta, começaram uma nova reorganização crescente ${ }^{118}$.

Denunciava-se a apropriação ilegítima do esforço produtivo das zonas libertadas, fruto do trabalho dos camponeses em condições de guerra e condenava-se que os donativos que recebíamos tais trabalhadores servissem para negociatas e enriquecimentos individuais ${ }^{119}$. Embora a FRELIMO acreditasse em preceitos que favorecessem ao coletivo, reconheceu o direito a propriedade familiar e privada, de mostrando assim que não havia na legislação

\footnotetext{
${ }^{117}$ Segundo Adam e Gentili (1983), alguns responsáveis pelo progresso dessas cooperativas, posteriormente vieram a se integrar a FRELIMO pela sua experiência política da Algodoeira Africana Voluntária de Moçambique (SAAVM) funcionou também, em simultâneo, como uma forma de desenvolver clandestinamente o debate político. Tinha como objetivo trabalhar no território de Cabo Delgado na zona norte de Moçambique nos anos de 1960. Essa organização fez várias ofensivas contra a rigidez da autoridade colonial em manter a estrutura de exploração. Entre suas reivindicações estavam o fim do trabalho forçado, a autorização para fazer a propaganda da SAAVM que prentendia, abrir lojas e vender os seus produtos, como; cabritos, galinhas e ovos, livres do controlo colonial e a preço aceitáveis ${ }^{117}$

118 Mosca (2005), afirma que o socialismo surgiu como uma alternativa ao capitalismo colonial, dentro do contexto da luta contra o apoio e os investimentos econômicos dos capitalistas ocidentais ao Governo português no controle da revolução moçambicana. A adoção do socialismo se tornou uma necessidade da recompensa aos recursos em formas de ajuda a libertação do povo do jugo colonial, suportado pelo bloco socialista. Esses laços coloniais em Moçambique definiram as questões principais revolucionárias, imprimindo marca do pensamento e à prática marxista, em volta do impacto do capital metropolitano sobre as estruturas sociais pré-capitalistas no pensamento contraditório estruturado inicialmente na década de 1960 pela FRELIMO. Portanto, durante este período, apesar das ajudas recebidas, a FRELIMO teve cautelas em definir o seu caminho ideológico. No entanto, é importante salientar que o socialismo sempre esteve indefinido e agindo de forma ambígua nas zonas libertadas, onde houve uma influência dos dirigentes, contidos de várias tendências socialistas que preponderavam no Leste-europeu e na África. ${ }^{119}$ Segundo Vieira (2010), não se tratava de uma visão de cumunismo primitivo, ou fundamentalismo marxuista, mas sim de uma análise bem realistica e fundada no sentimento legítimo das populações e militantes, que deviam arcar com o peso da actividade, sem em nada, ou em muito pouco, beneficiarem do resultado. Tratava-se de um momento concreto e em circunstância bem precisas que não se podem retirar do contexto. Não se deduza da posição entre afirmada pelo partido que se opunha da existência da propriedade familiar ou privada ou condenasse o direito a que cada um eriqecesse no quadro da ética e das normas.
} 
oposição de princípio a estes direitos ${ }^{120}$. Voltado para a organização econômica, os produtos alimentares constituíam a prioridade para a FRELIMO de organizar uma nova forma de organização do sistema econômico, servindo de experiências de trabalho coletivo em cooperativas de produção para abastecimento rural e a extração dos excedentes produtivos.

A FRELIMO realizou atividades através de uma rede de lojas asseguradas pelo Departamento de Produção quem orientava a produção agrícola no interior, assim como a venda no exterior os excedentes dos camponeses, sobretudo para o comércio com a Tanzânia. Com a destruição do sistema colonial desapareceram as companhias que impunham a produção de culturas de rendimento. O povo tornava-se livre para organizar a agricultura conforme desejasse e se concentrasse na satisfação das suas próprias necessidades. Como resultados da libertação de algumas regiões se verificavam um retorno à produção de culturas alimentares básicas como milho; mandioca, mapira, feijão e amendoim ${ }^{121}$.

${ }^{120}$ Ver. III CONGRESSO DA FRELIMO —, Diretivas econômicas e sociais, 1977.

${ }^{121}$ Ver Mosca, 2005. 


\section{IV-CAPÍTULO \\ Situação Econômica nos Últimos Anos da Colonização}

O quarto capítulo, sob o título, últimos anos da colonização, tem como objetivo caracterizar a estrutura econômica colonial, para melhor compreender quais foram às heranças econômicas colonial em Moçambique. De uma forma geral, pretendesse também, compreender a função objetiva do governo colonial de maximizar a extração de recursos através da exploração massiva. Nos últimos anos da colonização portuguesa, o governo colonial tinha a percepção da gravidade da situação política com que se debatiam as colônias, este processo era em volta da sua política contrária à independência e do seu autoritarismo político. A estrutura econômica de Moçambique de uma forma geral era caracterizada principalmente, por um lado, pela função objetiva de maximizar a extração de recursos através de formas de produção assente na exploração massiva da força do trabalho. Por outro lado, a economia era dependente de fatores e recursos econômicos externos, assim como, os setores econômicos possuíam poucas relações inter setoriais, o que ocasionava uma clara diferença entre diversas formas de produção e de economia.

Esta situação é de mostrada no setor "informal" onde os produtores de pequena escala tinham um grande peso na economia, apesar dos poucos recursos existentes quanto a capitais e uma baixa capacidade de realização de investimentos ${ }^{122}$. Cerca de 70 por cento da população ativa de Moçambique dedicava-se à agricultura, destas, praticamente 100 por cento eram mulheres ${ }^{123}$. Considerando apenas o emprego assalariado. Não é incluída a atividade de pequenas escalas e informais, a agricultura de subsistência e o assalariamento não declarado ou oculto, as percentagem dos sectores produtivos e não produtivo, distribuía-se da seguinte forma, conforme o gráfico abaixo:

\footnotetext{
${ }^{122}$ Ver. CENTRO DE ESTUDOS AFRICANOS. A Estrutura Econômica no Fim do Período Colonial. 1985.

${ }^{123}$ Ver. CARVALHO, Mário de. A Agricultura Tradicional de Moçambique. 1966
} 


\section{GRÁFICO 2.}

\section{Porcentagem dos sectores produtivos e não produtivos.}

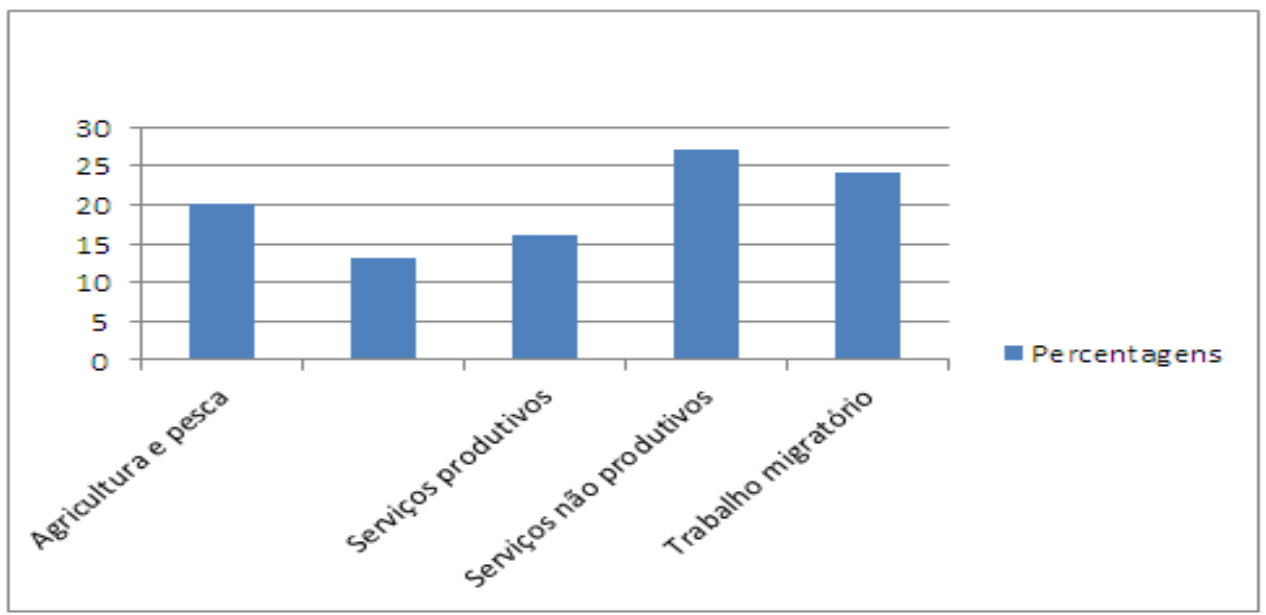

Fonte: Adaptado de Mosca (2005), in; IV Plano de Fomento, vol. 8, p. 5 -6.

Partindo dos princípios dos anos de 1970, Moçambique passava por uma rápida evolução econômica, que pode ser ilustrada pelo produto interno bruto (PIB), constituído da seguinte forma: agricultura, 19 por cento; indústria, 23 por cento; serviços produtivos, 39 por cento; serviços não produtivos, 19 por cento $^{124}$. O PNB de 1970 estava estimado num valor de US\$ 1804 milhões, um rendimento per capita aproximadamente de US\$225. As análises da evolução econômica dos finais do período colonial, apesar das poucas alterações estruturais sensíveis, houve acontecimentos conjunturais importantes que aprofundaram o crescimento econômico $^{125}$. Por exemplo, o IV Plano de Fomento chama à atenção para sinais conjunturais que viriam a ter reflexos na economia. A procura interna fortemente influenciada por fatores de duas ordens: a vultadas despesas de investimentos - sem contrapartida imediata na produção (oferta) - e inflação do crédito ao consumo ${ }^{126}$. As primeiras correspondem a riscos mais ou menos calculados sempre comportam os programas de desenvolvimento econômico. A segunda

\footnotetext{
${ }^{124}$ Segundo Mosca (2005), o Relatório Geral Preparatório do IV Plano do Fomento (1973) e o estudo de Pereira de Moura e de Amaral (s/d) estimam valores percentuais por setor que são aproximadamente calculados, principalmente na produção agrícola comercializada cerca de50 por cento do total eram produzido ${ }^{124}$, o que Wuyts (1978), diferenciavam bastante era anunciar as percentagens na distribuição do PIB por setor produtivo, que para ele seria das seguintes formas: na agricultura, 34 por cento; indústria, 19 por cento; serviços produtivos, 32 por cento; serviços não produtivos, 15 por cento.

125 Ver. MOURA, Francisco de, e AMARAL, Maria Fernanda (s/d): Estimativa do Produto Interno Bruto de Moçambique. Maputo, Universidade Eduardo Mondlane, Curso de Economia.

126 Ver. DIREÇÃO DOS SERVIÇOS DE PLANEAMENTO E INTEGRAÇÃO ECONOMICA. IV Plano de Fomento 1973.
} 
resultou de um processo desencadeado por pressões meramente monetárias-finasceira ${ }^{127}$.

Dentro desse processo se destaca a elevação da acumulação por meios de pagamento, com destaque para o crescimento de alguns setores produtivos devido à guerra, e o aumento da imigração colona que impulsionou à construção de infra-estruturas. Foram esses elementos da política colonial que estimularam a políticas fiscais e monetárias expansivas, fomentando a indústria alimentar ${ }^{128}$. De ressaltar ainda que a guerra apenas alcançasse as zonas econômicas importantes a partir de 1968-1969 após a operação Nó-Górdio, executado pelo exército português contra a guerrilha, principalmente desencadeado no Centro de Moçambique, por nesta região estarem afetadas importantes zonas econômicas nos distritos de Manica e Sofala ${ }^{129}$. Posteriormente, as zonas economias coloniais começaram a serem atingidas diretamente na Alta Zambézia, produtora de chá e com grande importância na produção do milho e tabaco, e de Manica e Sofala, importantes na produção de cereais e produtos frescos. As empresas produtoras de açúcar da Zambézia e de Sofala sofreram igualmente efeitos direitos da guerra. As principais vias de comunicação do Centro e Norte do país estavam sujeitas a constantes ataques ${ }^{130}$.

Neste período, com exceção de 1972, a balança de pagamento, foi sempre negativa. Porém, no fim de 1971 o montante "atrasado" deveria rondar pelos 5 milhões de contos. A reintegração nos circuitos monetário e financeiro da província era gerada através de um sistema bancário que, por vocação estrutural, o encaminharia para o mercado de capitais de curto prazo. Esse processo teve o seu principal reflexo na subida do montante de efeitos comerciais, que vinha crescendo a ritmo acelerado desde 1965 e atinge o nível sem precedentes de 8 milhões de contos em 1968, passa para 12 milhões de contos em 1969 e ultrapassa os 12 milhões em $1970^{131}$.

A movimentação do volume de créditos não controlado levou a uma inflação, o aumento da circulação fiduciária não encontrando cobertura nos valores do fundo cambial, reduzindo ao mínimo em resultados da deterioração da balança de pagamentos, haveria de

\footnotetext{
${ }^{127}$ Ver. MOSCA, João .Economia de Moçambique, Século XX. 2005.

${ }^{128}$ Mais informação sobre a economia colonial em Moçambique, ver Joana Leite; A formação da economia colonial em Moçambique. Pacto colonial e Industrialização: do colonialismo português às redes informais de submissão mercantil, 1930-74. 2000; Colonialismo e industrialização de Moçambique: pato colonial, dinamização das exportações e "importação de substituição" 1930-74. 1993.

${ }^{129}$ Fernando Amado Couto. Moçambique, 1974: o fim do império e o nascimento da nação. 2011.

130 Para mais detalhes sobre guerra ver. BERNADO, Manuel Amaro. Combater em Moçambique. Guerra e Descolonização, 1964-1975.2003.

${ }^{131}$ Mosca (2005).
} 
operar-se por elevação do plafond fixado no banco emissor. Efetivamente, este, que fora fixado em Julho de 1966 em 1900000 contos e se manteve inalterado durante três anos seguintes, é aumentando para 200000 contos em Fevereiro de 1970 e, ainda em Novembro do mesmo ano, para 27000 000. As pressões exercidas por esta inflação de créditos num mercado cujo abastecimento é fortemente dependente do exterior havia de se resolver em forte agravamento das importações. Assim, esta, que desde o principio da década de 1960 vinha crescendo à taxa anual de 7,7 por cento, aumentaram 11 por cento em 1969 e 25 por cento em 1970, passando de 6740 milhões de contos em 1968 para 9363 milhões em $1970^{132}$.

Essa inoperância do sistema e pagamentos inter territoriais, provocada pelo agravamento da balança de pagamento transmite a esta, por via do crédito ao consumo novo agravamento. A inflação determinada por este ciclo vicioso propaga-se a 1971, atingindo o seu pico no mês de Janeiro, em que os preços ao consumidor subiram de 11 por cento em relação ao mês anterior; e entre em rotura no segundo semestre por via de medidas restritivas das importações e outras, visando corrigir o sistema de pagamentos inter territoriais, alem de ações tendentes à reorganização do crédito, onde, salvo melhor opinião, teria residido à possibilidade de aproveitar favoravelmente as pressões conjunturais nascidas dos "atrasos". Assim, sendo os grandes difíceis da balança comercial parcialmente coberto pela balança de invisíveis (principalmente através das receitas dos salários definido dos mineiros e pelos serviços prestados pelos portos e caminhos de ferro). As relações comerciais deste período são observando no quadro a seguir, onde apenas cinco países somavam entre 50 e 70 por cento das exportações e importações. É fácil constatar a importância de Portugal e o crescente peso da África do Sul:

\section{TABELA 5.}

Exportações e importações (em percentagem, arredondado)

\begin{tabular}{|c|c|c|c|c|c|c|c|c|c|c|c|c|}
\hline Ano & \multicolumn{2}{|l|}{ Portugal } & \multicolumn{2}{|c|}{ África do Sul } & \multicolumn{2}{|c|}{ Inglaterra } & \multicolumn{2}{|c|}{ EUA } & \multicolumn{2}{|c|}{ RFA } & \multicolumn{2}{c}{ Subtotal } \\
\cline { 2 - 13 } & Exp. & Imp & Exp. & Imp. & Exp. & Imp. & Exp. & Imp. & Exp. & Imp. & Exp. & Imp. \\
\hline 1960 & 48 & 28 & 3 & 12 & 8 & 14 & 6 & 6 & 2 & 10 & 67 & 70 \\
1965 & 37 & 34 & 12 & 11 & 5 & 11 & 5 & 4 & 4 & 8 & 60 & 68 \\
1969 & 41 & 31 & 11 & 15 & 5 & 8 & 10 & 7 & 3 & 8 & 70 & 68 \\
\hline
\end{tabular}

Fonte: UN Statistical Offce, Yearbook of International Trade Statistics.

\footnotetext{
132 Ver. Mosca (2005).
} 
Porém, um número reduzido de produtos primários (agrícola) representava mais de metade das exportações. Entretanto, outras economias africanas possuem exportações mais dependentes de uma qualidade inferior de produtos ${ }^{133}$. Todos eles eram exportados com uma primeira transformação que pretendia facilitar ou permitir a exportação ${ }^{134}$. Conforme aponta o gráfico 3:

GRAFICO. 3.

Principais Produtos Exportados (em percentagens do total das exportações).

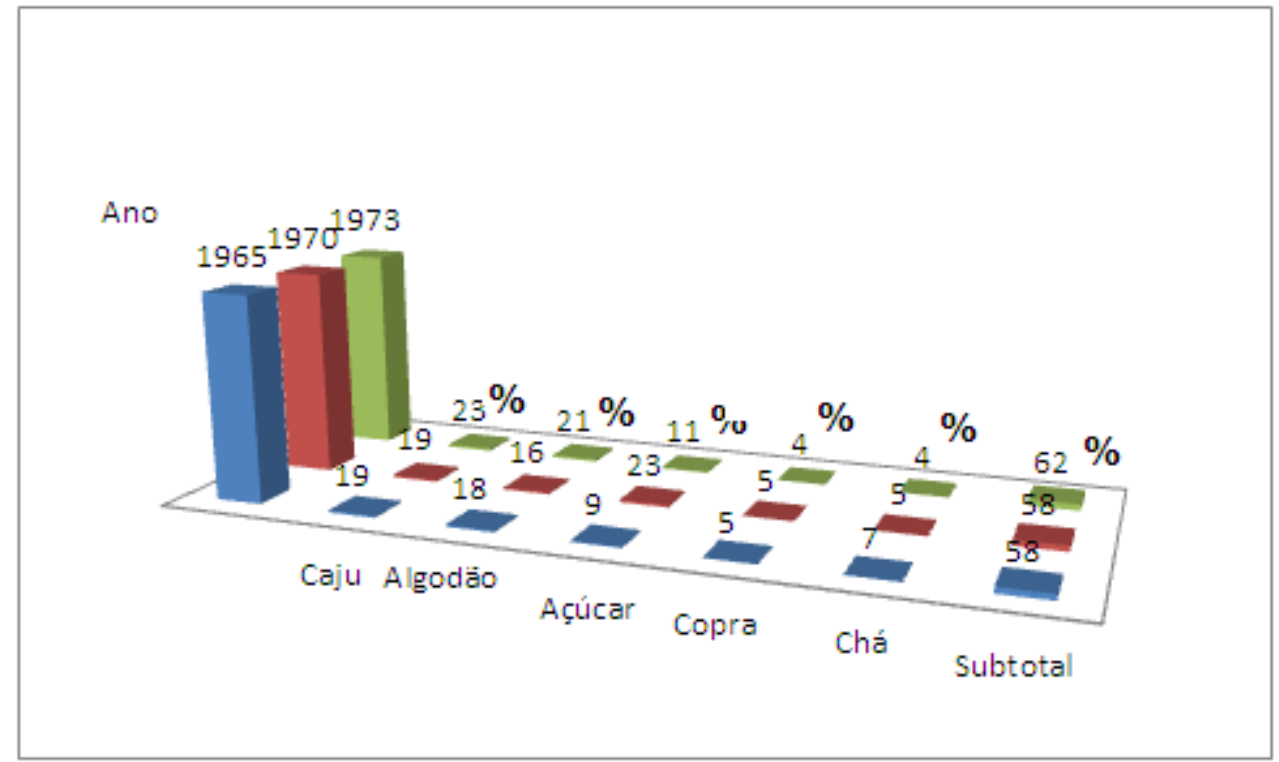

Fonte: National Planning Commission (1984).

Os dados das importações mais na tabela 6 abaixo confirmam as prestações das políticas de substituição de importações, de redução dos produtos alimentares e têxteis e, por outro lado, confirmam a modernização da economia e as mudanças do capital, os termos de troca deterioram-se, o que é marcado em 1972, o regime procurou compreender os problemas que reduziam os mecanismos de aceleração do crescimento econômico, destacando: as políticas monetárias expansivas e as conseqüências sobre a inflação que se descontrolou; as transferências para metrópole com efeito sobre a balança os equilíbrios macro econômicos da colônia,

\footnotetext{
${ }^{133}$ Ver. NEGÃO, José . Cem Anos de Economia da Família Africana. 1991.

${ }^{134}$ Ver. BRITO, Luís . Dependência Colonial e Integração Regional. Estudos Moçambicanos. 1980.
} 
sobretudo sobre a balança de pagamento; o crescimento econômico dependente de importações; o financiamento da economia com emissão de moeda. Ressalta-se que, os efeitos da guerra como uma das razões fundamentais do fracasso da evolução econômica de Moçambique nos finais da década dos anos $1960^{135}$. As importações principais eram equipamento e metais, alimentos e têxteis, conforme se pode observar na tabela seguinte:

TABELA 6.

Principais produtos importados (em percentagem do total das importações)

\begin{tabular}{|r|r|r|r|r|}
\hline \multicolumn{1}{|l|}{ Anos } & Alimentos & \multicolumn{1}{l|}{ Têxteis } & $\begin{array}{r}\text { Equipamento e } \\
\text { Metais }\end{array}$ & Subtotal \\
\hline 1965 & 19 & 16 & 37 & 72 \\
1970 & 14 & 12 & 46 & 72 \\
1973 & 12 & 9 & 53 & 74 \\
\hline
\end{tabular}

Fonte: National Planning Commission (1984).

Embora a percepção da economia de Moçambique em princípios dos anos 1970 fosse de um aparente progresso, as preocupações existentes eram já evidentes os sintomas de uma crise anunciada resultante das políticas econômicas coloniais das últimas duas décadas. Neste processo, agonia do regime colonial estava centrada na luta armada que se estendia a sua força libertando certas zonas nas províncias de Cabo Delgado, Niassa e Tete e alargava-se fortemente rápido para Manica e Sofala, rumo ao sul do país. Acresce que nunca a guerra se havia aproximado de um centro urbano da importância como a cidade da Beira que é a segunda maior economicamente e politicamente do país ${ }^{136}$.

Para a FRELIMO, com aproximação da luta aos centros estratégicos de desdobramento das tropas coloniais, feria os pontos mais sensíveis e dolorosos do sistema. Um reduzido número de funcionários públicos descontentes, pela redução dos seus salários que defendia a falsa idéia que a população branca da colônia de Moçambique, era conformada com os privilégios, passou a

\footnotetext{
135 Ver. Couto (2011).

${ }^{136}$ Uma cidade como a Beira pela sua característica tão especifica não tardaria a reagir á aproximação da luta armada nas suas imediações. Já não se tratava de relatos verbais de combates num longínquo Norte, ou não menos longínquas província de Tete, era ai mesmo ás suas portas, afetado o quotidiano da vida da população, sobretudo a das minorias raciais, mais esclarecidas e convictas da imutabilidade e da invencibilidade do sistema. Para maior grassava o sentimento de que a independência já não seria uma quimera. Enquanto batia apressadamente à sua porta (COUTO, 2011).
} 
ter uma crise ideológica. E mostrou que esta generalização era falsa, porque sempre houve pequenos núcleos de opositores aos governos de Salazar e de Caetano. Assim como, na cidade Beira, bem menos complexo que a capital Lourenço Marques (atual Maputo) onde proliferavam membros ativo do Partido Comunista Português, com uma agenda própria ${ }^{137}$.

Este movimento contribuiu fortemente para a queda do regime salazarista e de Marcelo Caetano, influenciados pela Revolução dos Cravos, a 25 de abril de 1974 em Portugal, onde suportaram os seus ideais sobre a implantação de um regime democrático ${ }^{138}$. Entretanto, nesse propósito de conter o descontentamento no seio do povo português, o governo português procura assinar o cessar fogo com a FRELIMO. Esse processo teve uma grande interferência da máquina soviética, sobretudo, valorizando a presença das forças de esquerda no governo provisório português, impedindo que a FRELIMO passe a independência como um governo autônomo e Moçambique fosse um país descolonizado. Assim, não punham em perigo as conquistas dos socialistas portugueses. Porém, o interesse dos moçambicanos pesou mais alto, para a liderança do Mário Soares do Partido Comunista Português (PCP) que procurou minimizar os ânimos abrindo a mão para os impasses entre os interesses marxistas daquele momento das negociações do cessar fogo a sete de Setembro de 1974. Durante o processo de transição, houve principalmente nas principais cidades de todo Moçambique pequeno núcleo revolucionário que queriam assaltar o poder da FRELIMO na última hora, movidos pelo ensejo de negociações pacificas com a FRELIMO e com o governo colonial ${ }^{139}$.

Não era fácil essa escalada por a estrutura colonial não permitir as negociações pacifica.

137 Porém, o pequeno grupo da oposição na cidade da Beira era, na sua essência, compostos por pacíficos intelectuais de esquerda, que se dedicavam à tertúlia política, a PIDE reconhecia os membros do grupo, mas tolerava-os porque entendia que não seriam eles a derrubar o regime. Eram favoráveis à independência e numa esconderam essa opção. Alguns ajudaram materialmente militantes da FRELIMO na clandestinidade, contribuindo muitas vezes para as suas longas e perigosas viagens rumo á Tanzânia. Não tinha a ilusão que a terra onde viviam não era a deles. Este grupo será enriquecido, nos anos de 1965 a 1967, com a inclusão do cantor Zeca Afonso, feito professor de Geografia no Liceu Pêro de Anaia. Este fruto dos tempos e dos ventos que se viviam, em finais de 1972 entra em cena política beirense um novo grupo: a extrema-esquerda. Constituída pelos filhos dos intelectuais de esquerda e por alguns jovens transviados das famílias da elite social, parecendo assim dar razão ás teses leninistas sobre o esquerdismo e os pequeno-burgueses. Encontraram nos pensamentos do "camarada Mao", condensado no Livro Vermelho, uma das suas fontes de inspiração ideológica. Por outro lado, este grupo foi influenciado pela audição da voz da FRELIMO, transmitida diariamente através da Zâmbia Broad-casting, trazendo uma consciência nacionalista. Não se limitando ás divulgações ideológicas. No espírito tão característico da esquerda radical, aliado à generalidade e à ingenuidade da juventude, procuraram uma ação com impacto imediato, na linha do grande líder de "ousar lutar, ousar vencer", estes grupos para atingirem esse objetivo, desenvolveram-se alianças com outros núcleos (COUTO, 2011).

${ }^{138}$ Para mais informações ver, Fernando Rosas. “O marcelismo ou a falencia da politica de transição na Estado Novo". 1999.

139 Ver Vieira (2010). 
Muito deste grupo surgira no Centro de Moçambique, a exemplo da cidade da Beira, a este grupo juntaram-se, de forma bem mais moderada, alguns empresários, unidos em torno da Associação comercial da Beira. Para eles, a independência do país não estava decididamente na sua agenda. Era um conjunto de pequenos e médios empresários, sem aproximações ou ligações aos grandes grupos econômicos metropolitanos ${ }^{140}$. Por outro lado, iam surgindo partidos políticos que pretendiam apresentar uma solução de fundo que passava pela constituição de um grupo político reconhecido por Portugal e pela celebração de um acordo com vista á independência, num calendário de sete anos. Assim sendo, esta proposta não teve apoio de Portugal nem da FRELIMO $^{141}$.

A estrutura política e a orientação ideológica de Moçambique neste período do Governo de Transição estavam em volta da crença na credibilidade junto às organizações internacionais ou no quadro de relações bilaterais de modo a responder as necessidades do desenvolvimento do país. Estas transformações tiveram como base inserção de um grande projeto socialista nacional, que levou a transformações radicais nas relações sociopolíticas, econômicas e culturais da sociedade moçambicana. Porém, os seus efeitos começaram com as nacionalizações que emergiram da situação que piorava cada vez mais com as instabilidades, por não saberem da continuidade dos seus investimentos.

${ }^{140}$ De acordo com Couto (2011), entre eles sobressaíram Francisco Barreto e Nunes de Carvalho. Ambos haviam sido presos pela PIDE .

${ }^{141}$ Segundo Couto (2011), o GUMO, Grupo Unido de Moçambique, liderado pelo Dr. Máximo Dias e Dra Joana Simeão. Foi um exemplo deste movimento que teve a sua curta história, com uma base social de apoio centrada no Centro Africano de Manica e Sofala, agrupava a elite dos "assimilados" apoiava de forma direita ou indireta o regime colonial. Este movimento defendia uma solução sobre o futuro da colônia, procurando uma audiência com Marcelo Caetano. Para manifestar o descontentamento com o rumo dos acontecimentos em Moçambique. Os representantes desse movimento apesar de terem um contacto com os dirigentes da FRELIMO, inclusive o Eduardo Mondlane, enquanto vivo. Nunca se entenderam politicamente com os seus compatriotas. A este grupo foi-lhes reservado outras agendas não política e não foi permitido um melhor ambiente de negócios, porque a sua atitude de primazia excessiva pelo exercício da atividade associativa e pelo respeito pelas regras democráticas. Sempre procurando melhorar as transformação econômica importantes, de forma a que se desenvolva o país entre os anos de 1973 a 1977. 


\section{SEGUNDA PARTE}

\section{A FORMAÇÃO DA ECONOMIA SOCIALISTA}

Da Guerra Colonial à Libertação (1962-1974). 


\section{V-CAPÍTULO \\ Das Independências as Nacionalizações}

Este capítulo faz referência à situação que levou a nacionalização em Moçambique como uma das primeiras políticas da estatização rumo à organização socialista. Começa por mostrar que o projeto econômico, política e social do Governo de Transição (1974-1975) não transmitiram a crença junto às organizações nacionais e internacionais de modo a responder as necessidades do desenvolvimento do país. Isto, pelo grande projeto socialista, que se pretendia desenvolver, o que provocou reações radicais nas relações sociopolíticas, econômicas e culturais da sociedade moçambicana.

Estas ações alem da sabotagem resultou na descapitalização e decisões antieconômicas de alguns empresários no momento da partida de Moçambique de algumas empresas em que foram abandonadas geridas pelos técnicos colonos. As propagandas da FRELIMO criavam em muitos casos momentos de incerteza nos investimentos a seguir pós a independência, com um governo que se manifestava de forma socialista. Dizia as autoridades portuguesas no seio da comunidade empresarial, que desconheciam a política socialista da FRELIMO e, que ela era um "espantalho comunista", que dependia dos 'russos', e que podiam tomar as suas riquezas até as suas galinhas.

As propagandas da FRELIMO criavam em muitos casos momentos de incerteza nos investimentos a seguir pós a independência, com um governo que se manifestava de forma socialista. Dizia as autoridades portuguesas no seio da comunidade empresarial, que desconheciam a política socialista da FRELIMO e, que ela era um "espantalho comunista", que dependia dos 'russos', e que podiam tomar as suas riquezas até as suas galinhas ${ }^{142}$.

Essa idéia levou com que alguns colonos instigassem sentimento de revolta, onde começaram a matar os seus gados e destruírem máquinas, até os manuais de manutenção. Um problema que surgiu dentro da FRELIMO, foi que ao conduzir a independência, não mostrou a sua posição oficial e na realidade, em muitos casos, não ajudou a prevenir a saída de um grande número de estrangeiros e nacionais de recursos e capitais. Assim sendo, no período da independência a 25 de junho de 1975, abandonou o país mais de 100.000 portugueses, como resultado da falta de compreensão dos discursos políticos radicais na ideologia interna da

\footnotetext{
${ }^{142}$ Ver. Gentili (1998).
} 
FRERLIMO, em conseqüência da evolução política e econômica em Portugal ${ }^{143}$.

A FRELIMO pouca (ou nada) fez para travar a saída dos empresários. O discurso dizendo que no Moçambique independente havia lugar para todos não foi correspondido com ações concretas. Conformando, os ambientes criados e conduzidos localmente "espontâneos", que dificultavam a continuidade da comunidade estrangeira ${ }^{144}$. Essa situação é a base impulsionadora do crescimento do sector estatal, não só como resultado das ações programadas de forma a dar coerência ao novo setor social de produção. Mas também, pelos problemas das empresas existentes até o momento, que tinham um caminho de incerteza do desenvolvimento das suas atividades no socialismo da FRELIMO ${ }^{145}$.

A política financeira neste período foi um reflexo do sistema fiscal, por ser o um instrumento que garantia a canalização dos excedentes da produção, bem como das bases de segurança dos sectores socioeconômicos prioritários. Porém, a política fiscal em relação aos rendimentos do trabalho foi orientada para o estabelecimento de taxas diretamente proporcionais aos níveis de rendimento. Entretanto, houve garantia de muitos trabalhadores poderem ser pago salário baixos, aproveitando de forma lucrativa os investimentos empresariais. (Este processo deu-se devido a necessidade do Estado exercer um controla efetivo do sector financeiro e assim como, procurar o cumprimento dos objetivos da estratégia de desenvolvimento econômico e social) $)^{146}$

A necessidade de resolver o problema levou com que o novo Estado começasse com as nacionalizações, onde em muitos casos, a grande e moderna empresa industrial é total ou parcialmente propriedade do Estado. Mesmo quando a propriedade permanece privada, o elemento critica na determinação do nível de investimentos e na escolha da tecnologia continua a

\footnotetext{
${ }^{143}$ Para além da saída de portugueses, aconteceu de forma semelhante com estrangeiros de outras nacionalidades e também de muitos moçambicanos (MOSCA, 2005).

144 Ibidem.

${ }^{145}$ Ver. Cardoso (1993).

${ }^{146}$ Por exemplo, o Estado teve que desenvolver a gestão de todos os setores bancários portugueses que operavam em Moçambique ${ }^{146}$, reestruturados em duas novas instituições bancaria: o Banco de Moçambique (BM), com funções de banco central, e das operações externas, e o Banco Popular de Desenvolvimento (BPD), como banco comercial, que tinha como atribuição principal o financiamento da economia (A banca funcionava sobre as orientações dos ministérios do Desenvolvimento e de Planificação Econômica (MDPE), e das Finanças, onde a tarefa era financiamento das empresas estatais e realizações das operações externas). Nestas instituições, a intenção dos poderes segundo Mosca (2007, p. 443), "era de defender o sistema financeiro, o que a segurança (garantia) dificultava o acesso dos agentes econômicos de pequena ou muito pequena escala, por regra, sem tradição nem forma”. Outro motivo que dificultou as acessibilidades do sistema financeiro foi especialmente a sua concentração..
} 
ser a política pública por meio dos sinais macroeconômicos do estado, seus investimentos complementares em infra-instrutora e seu direcionamento setorial ${ }^{147}$. Nesta ótica de idéias as empresas privadas em Moçambique no período pós-independência ficaram limitadas as obrigações, regidas para os proprietários, em que não podiam tirar rendimentos, e tinham de pagar impostos progressivos, fixados segundo critérios de justiça social. O capitalismo estrangeiro foi centralmente manipulado para responder as políticas econômicas do Estado. Entretanto, estas medidas foram implantadas a partir do primeiro decreto do Governo de Transição publicação no Decreto-Lei no 16/76, de 13 de Fevereiro de 1975, “o qual permitiu através da nomeação de "comissões administrativas"148 (CA), a intervenção e tutela do Estado sobre empresas abandonadas ou sabotadas".

Porém, o Estado necessitava de responder o os efeitos do abandono dos empresários com característica própria na economia com a estratégia de intervenções, onde o Estado tinha com objetivo em curto prazo gerir o funcionamento das empresas, fase a ameaça da ruptura de abastecimento de insumo e de matéria-prima, sobretudo das importações e exportações. Para os empresários que permaneceram no país depois da independência, a FRELIMO admitiu que participassem nas atividades não estrategicamente de grande importância econômica, mediante o cumprimente dos critérios, de participação na produção nacional, no quadro dos objetivos fixados pelo Estado, e de acordo com os interesses das massas populares ${ }^{149}$.

Um aspecto particularmente importante da atividade privada de moçambicanos é que por muito tempo, fizeram grande parte, os artesãos e os pequenos proprietários. Estes empresários garantirão, com o apoio do Partido Estado, a estabilidade de vida dos cooperantes, a colocação e venda dos seus produtos e o abastecimento de matérias-primas em condições mais favoráveis. Dependendo das necessidades do Estado em aproveitar os recursos existentes, os novos investimentos de capital privado, interno ou externo, foram autorizados. Mas, este processo dependeu principalmente da incidência da função do capital na edificação da base econômica, quer produzindo divisa através da exportação quer contribuindo para a satisfação das necessidades fundamental do Povo, e sempre condicionada à obrigação de formar e elevar o

\footnotetext{
${ }^{147}$ Fishlow, apund Saes (996).

${ }^{148}$ Eram nomeadas por despacho ministerial e geralmente eram constituídas por três elementos: um gestor; outro da "confiança do partido" e um terceiro, geralmente do GD da respectiva empresa (CARDOSO, 1993).

149 Ver. CARVALHO, Anabela Soriano. Empresários em Temos de Guerra. O caso de Moçambique, 19741994.2008; CASTEL-BRANCO, Nuno. Opções Econômicas de Moçambique 1975-95. 1995.
} 
nível técnico e científico dos trabalhadores moçambicanos ${ }^{150}$.

A recepção de braços abertos dos empresários que permaneceram no país, por parte da FRELIMO, foi para juntos tentarem juntar as peças de uma economia já fraturada pelos custos da Guerra colonial e depois em grande parte abandonada por aqueles que anteriormente controlavam os postos gestores e administrativo. Porque os moçambicanos negros tinham sido em geral excluídos dos negócios e dos cargos do serviço público e mesmo empregos de níveis mais baixo como de cobrador de bilhete nos comboios era dificil de encontrar uma mão de obra qualificada $^{151}$. Porém o regime ia se edificando de forma a socialização a seu modelo, mas comprendendo a organização e política econômica dos outros Estados socialistas, onde passou a ter muito cuidado com à organização e defesa do poder.

Neste ponto o regime da FRELIMO já estava ideologicamente radicalizado nos ideais socialistas, referentes à organização do Estado e na política econômica. Mas, os discursos faziam constante referência ao capitalismo como um sistema de exploração, à coletivização das formas de produção, á terra como propriedade do Estado, à propriedade da redução das necessidades do povo $^{152}$. Necessariamente poucos dias após a independência, principalmente a 24 de julho de 1975, Samora Machel anunciou a nacionalização da educação e da saúde, da terra, das empresas funerárias (o "negócio da morte") e serviços de advocacia, proibindo qualquer atividade privada nestes setores.

No dia 3 de Fevereiro de 1976, foi anunciada a nacionalização dos prédios de rendimento e proibiu-se o arrendamento privado da habitação, um 'golpe de misericórdia' nas expectativas dos pequenos e médios investidores que, apesar de muito deles terem saído de Moçambique, ainda mantinham em aberto a possibilidade do regresso a Moçambique. Estas nacionalizações por vezes foram entendidas como não econômico, com realce para o objetivo da medida de canalizar o esforço para acabar com a descriminação social nos centros urbanos. Mas, também pretendia vibrar um golpe na remanescente base econômica de estratos "indesejados" da chamada burguesia colonial. Esta afirmação pode sustentar algumas versões que referem que a FRELIMO tinha o firme propósito de tomar medidas que 'empurrassem' a comunidade colona

\footnotetext{
${ }^{150}$ Segundo Mosca (2005), esta necessidade de equilíbrio entre os setores privados e publico, nenhuma teoria econômica descreve como precisa, possivelmente por se tratarem de equilíbrio politicamente conflituoso e existem muitas realidades muito diferenciadas.

${ }^{151}$ Hanlon, 2008.

152 Ver. DEPARTAMENTO DE INFORMAÇÃO E PROPAGANDA DA FRELIMO — O processo de revolução democrático-popular em Moçambique, 1974.
} 
para fora de Moçambique. Não é possível referir com exatidão sobre as intenções desta nacionalização; nada indica que esta última versão constituísse o objetivo da FRELIMO, embora o efeito produzido sobre a comunidade estrangeira fosse previsível ${ }^{153}$.

As nacionalizações em Portugal tiveram um peso maior para as nacionalizações que iam decorrendo em Portugal como a principal influencia dos principais discursos da nacionalização de alguns sectores econômico, o que provocaria um aumento do número das empresas efetivamente administrados ou sob tutela do Estado, nomeadamente no caso do sistema bancáriofinasceiro (banca e seguros) e uma parte importante do sistema industrial. Esse crescimento do sector estatizado decorreu mais do processo de descolonização e das nacionalizações em Portugal que de políticas econômicas ativas empreendidas pelo novo poder em Moçambique ${ }^{154}$. Isso levou com que, parte importante do sector empresarial do Estado existente na pósindependência fosse formada em bases contingenciais, não econômicas e sem um fio condutor enérgico $^{155}$. Recorda-se, no entanto, que as grandes empresas estrangeiras, de todos os sectores econômicos, não foram nacionalizadas nem intervencionadas. Foram principalmente as empresas que estavam associadas a interesses no exterior e, que transferiam matérias-primas, como por exemplo, algodão e copra, empresas de importações e de prestação de serviços de máquinas industriais e de meios de transporte. Nestes casos, os interesses não fora afetados: as transferências de recursos mantiveram-se através das exportações e os padrões de acumulação mantinham-se no exterior, onde a reprodução do capital se processava no fundamental.

As grandes empresas não tinham interesse em dar motivos para que o governo as nacionalizasse ou interesse com a aplicação do Decreto-Lei n. ${ }^{\circ}$ 16/76. Por outro lado, o governo não possuía condições nem eventualmente interesse para mais nacionalizações: o sector estatal crescia de forma não programada e ultrapassando as capacidades do governo; as grandes empresas operavam em sectores de grandes importâncias para a economia; finalmente existiam forças políticas e sociais externas relacionadas com estas empresas ${ }^{156}$. Assim sendo, a manutenção destas empresas era a salvação para as empresas abandonadas que colocavam em crise os setores estratégicos da economia, tradicionalmente controlado por estes empresários que

\footnotetext{
${ }^{153}$ Ver. Mosca (2005).

${ }^{154}$ Cardoso (1993) queria referir-se ao sector produtivo, com exceção daquele onde a Frelimo tomou iniciativas através das nacionalizações. Grande parte (mesmo) a totalidade do sector industrial, agrícola, comercial, do turismo, entre outros, tornou-se propriedade do Estado por meio das intervenções no quadro da Lei n ${ }^{\circ}$ 16/76 (conhecido como o 24/20).

155 Ibidem.

156 Ibidem.
} 
acabaram por sair do país. Na sua maioria operavam em áreas como: indústria de construção, pequena e média indústria e artesanato, redes comerciais urbanas e rurais, empresas agrícolas de grande dimensão em várias regiões ${ }^{157}$.

A representatividade do sector privado era nichos do mercado, controlo pelo Estado e ineficaz ou inadequado, aos modelos de planificação em que estavam sujeitas, com as sociedades $\operatorname{mistas}^{158}$. A burocracia nos financiamentos das empresas privadas só permitiu os investimentos em atividades das pequenas empresas. Caso contrário, uma exceção especificamente, no caso de: um banco privado, plantações de chá e açúcar, e outras empresas privadas. O governo independente encontrou-se perante um país com uma economia atrasada, frágil e em grande parte destruída, para, além disso, tinha em sua volta vizinha hostilidade e poderosos, a África do Sul da apartheid e a Rodésia governada por uma minoria branca ${ }^{159}$. A economia herdada era claramente deficitária devido a um desequilíbrio macroeconômico notório, por um lado era, a dependência de Moçambique das tarifas portuárias e ferroviárias, dos salários dos mineiros. Por outro lado, por ser um país com um desenvolvimento econômico desigual, havendo regiões claramente marginalizadas, o que na sua origem as assimetrias permaneceram até aos nossos dias.

Desta forma, a opção política, coerente com a lição da luta de libertação, tendia a subverter as estruturas herdadas para construir um novo tipo de Estado e de sociedade em que o valor supremo deveria ter sido a organização de formas de democracia na base da sua estrutura. Entretanto, no processo de nacionalização, as grandes empresas públicas do período colonial passaram a fazer parte da gestão direta do Estado, como o caso; das empresas monopolistas de transporte aéreo (a DETA deu origem à LAM - Linha Aérea de Moçambique); os caminhos de Ferro de Moçambique (CFM) mantiveram com o mesmo nome; todas as empresas rodoviárias de transporte de passageiros intervencionadas foram integradas em três grandes monopólios regionais - sul, centro e norte - com o nome de ROMOS (Rodoviária de Moçambique Sul),

\footnotetext{
${ }^{157}$ A rede de comercialização que encabeçava a exploração dos principais produtos e, em primeiro lugar, do algodão, dissolveu-se; o sistema de transporte foi destruído. As conseqüências foram o desemprego e a rápida deterioração dos níveis de produção, acelerando sem uma programação concisa o processo das nacionalizações, tornando-o economicamente irracional, desequilibrado e em médio prazo não sustentável (PICHER, 2003).

${ }^{158}$ Picher (2003) ao fazer uma interessante análise sobre as empresas que sobreviveram á transição econômica de Moçambique do colonialismo para a independência. Defende que, o existiu um sector privado residual que sobreviveu e salvou bem como minou, o projeto socialista que o governo da FRELIMO tentou levar a pratica. Esse sector privado ocupou nichos do mercado controle pelo Estado e se revelou inadequado ou ineficaz.

${ }^{159}$ De acordo com Gentil (1998), a independência foi acompanhada de violência árdua.
} 
ROMOC (Rodoviária de Moçambique Centro) e ROMON (Rodoviária de Moçambique Norte) 160.

O cargo de direção dos antigos funcionários portugueses que abandonaram o país antes da independência passou a ser confiado com base na confiança política ${ }^{161}$, entre os militantes da FRELIMO: uns vindos da luta armada sem experiência de gestão pública e empresarial e com pouco conhecimento das realidades; outros, recém-formados nas escolas superiores e médias, jovens majoritariamente oriundos da pequena e média burguesia colonial e das elites tradicionais; outro grupo resultou de promoção de quadros subalternos do aparelho de estado colonial com base no voluntarismo e engajamento político nos Grupos Dinamizadores; finalmente chegaram ao país muitos técnicos estrangeiros no quadro de cooperação bilateral, de organizações internacionais e através de contratos individuais, sem conhecimento do país e com deficiente enquadramento dos técnicos nacionais ${ }^{162}$. A integração de cidadãos não-negros em cargos de responsabilidade era explicada à luz da sociedade anti-racista do ideário da FRELIMO $^{163}$.

\footnotetext{
${ }^{160}$ Assim sendo, o período a pós a independência em Moçambique, a estrutura produtiva monopolista manteve-se ou foi reforçado, o que era coerente com a concepção de organização da economia com base no setor estatal e em grandes empresas (SAÚTE, 2010).

${ }^{161}$ Segundo Mosca (2005), o diretor do CAIL tinha sido secretário de Estado da Agricultura no primeiro elenco do governo de transição, foi diretor nacional da Agricultura no primeiro elenco do Ministerio da Agricultura, após a independência, foi eleito membro da Assembléia Popular, possua um apelido sonante das elites locais, tinha acesso aos mais altos cargos do Estado em Maputo, com quem resolvia as questões da empresa. Não era caso único: as empresas consideradas estratégicas eram dirigidas por quadros de confiança política e com preparação técnica; ser diretor duma destas empresas significava a pertença às novas elites moçambicanas que configuravam as recentes alianças da Frelimo.

$162 \mathrm{O}$ discurso político reivindicava a constituição do poder e as nomeações de responsáveis com base na confiança política e na capacidade técnica e que as estruturas governamentais representavam o conjunto do país e da nação e não as regiões ou as etnias. Pretendia-se que a composição dos governos transmitisse a imagem de unidade nacional e de combate ao regionalismo e tribalismo; porém, os elencos representavam claramente as alianças sociais da FRELIMO entre etnias e com grupos sociais minoritários. Exemplo, se refere a aliança chagane-macondes (os primeiros do Sul, principalmente da província de Gaza, majoritariamente a elite intelectual e alguns chefes militares; os segundo, sobretudo do planalto de Mueda, foram os que suportaram uma parte significativa dos sacrifícios da guerra e estavam representados ao nível da hierarquia militar e de segurança) (MOSCA, 2005).

${ }_{163}$ Delegações da FRELIMO e do governo de Moçambique em missão de serviço no estrangeiro era geralmente integradas por pessoas de várias raças, o que, em muitos países, sobretudo africanos, causava algumas observações. Samora Machel chegou a afirmar que em Moçambique um branco poderia ser presidente da Republica, possivelmente um pouco para transmitir um exemplo dos ideais da FRELIMO (ou dele).
} 


\section{VI-CAPÍTULO \\ A Produção nas Aldeias Comunais}

Neste capítulo, intítulado, A Produção nas Aldeias Comunais, objetiva mostrar os mecanismos socialistas usados para realizar a organização da força de nas zonas rurais para que se estruturem uma sociedade revolucionária. Em última análise, as aldeias mostram como as populações viveriam organizadas para desenvolverem a produção coletiva, promovendo intercâmbio dos seus conhecimentos. Este discurso referido na tomada de posse como Presidente da Republica, Samora Machel em 1975, sustentava que era necessário que houvesse o sistema das Aldeias Comunais.

Desta forma, se pretendia que estas aldeias fossem acima de tudo, uma forma de organiza a população dispersas das zonas rurais para que se estruturem em sociedade revolucionária, organizada para desenvolver o trabalho coletivo, assim, promovendo o intercâmbio dos conhecimentos nos trabalhadores. Assim sendo, as aldeias comunais, seria as cidades do campo, uma forma de combater os vícios, o boato e a calúnia das cidades em contrapondo com a pureza e o espírito de sacrifício dos camponeses ${ }^{164}$. Esta estratégia constituía o principal revelador das experiências teórica e pratica do desenvolvimento rural aprendida pela FRELIMO durante a guerrilha.

Entretanto, o enquadramento dos camponeses as aldeias comunais de formas econômicas e sócio-políticas eram consideradas etapas para o desenvolvimento rural. Uma das experiências "nacionais" que mais próximo estaria da concepção de um desenvolvimento rural endógeno, baseado nos valores "tradicionais e nas relações "pré-capitalistas”, projetados após 10 anos de independência na Argélia ${ }^{165}$. Um processo de enquadramento das relações socialistas no campo, como um novo estilo de vida sustentado com base nas condições econômicas racionais e assegurado pela fixação da população. O processo estava dentro de uma plataforma estrutural agrário que enquadrava as cooperativas, formando um verdadeiro complexo sócio-econômico,

${ }^{164}$ Discurso de Samora Machel no comício de 3 de Fevereiro de 1976. Um alto responsável da FRELIMO referia sobre este assunto numa conferência de jornalistas: "As cidade moçambicanas tinham sido fortalezas do inimigo e não apenas num sentido militar. Elas eram também as fortalezas da ideologia do inimigo, os viveiros onde o colonial-capitalismo inculcava e permanentemente desenvolvia a sua ideologia de opressão e exploração" (MOSCA, 2005).

${ }^{165}$ Ver. BOURDIEU, P. \& SAYAD, A. Na sua obra. Le déracimement: La crise de l'agriculture traditionnelle en Algérie. 1964. Refere que, como um programa de re-estruturação ordenada da zona rural uniforme, as 1000 aldeias socialistas da revolução argelina, tiveram uma prática de auto-gestão, iniciada em 1972, tendo em vista a materialização dos objetivos de "socialismo aldeão" para responder o setor rural com os ideais socialistas. 
que garantiam o conjunto das funções econômicas e serviços administrativos, sociais e culturais $^{166}$.

A experiência de aldeamento nos moldes socialistas em Moçambique também vem das aldeias ajumaa da Tanzânia ${ }^{167}$. Um programa inseria na política de desenvolvimento rural entre 1962-1966, na qual, outro projeto de colonização agrícola já haviam desenvolvido, com objetivo principalmente de incentivar a produção agrícola entre os camponeses. Transformando radicalmente o modo de produção familiar para uma produção agrícola de exportação ${ }^{168}$. Para tal, dever-se-ia criar empresas agrícolas modernas propulsionadas aos camponeses para a sua transformação em agricultores, com as vantagens do tipo urbano, onde teriam; água canalizada, habitação melhorada, comunicação, comércio, educação e serviços sanitários ${ }^{169}$.

Teoricamente os processos de aldeias comunais desenvolvidas na Argélia e Tanzânia foram os espelhos que se projetaram adulteradamente em termos de condições para ser ensaiado em Moçambique. Esse processo pretendia definir a reestruturação da organização de produção do meio rural nos moldes socialistas partindo das aldeias comunais e cooperativas, como as formas coletivas de produção e de vida ${ }^{170}$.

A lutar contra o capitalismo e a dispersão do habitat rural, levou com que as cooperativas de produção e comercialização dos produtos agrícolas surgissem de forma

\footnotetext{
${ }^{166} \mathrm{Na}$ opinião de analistas que se debruçam sobre estas experiências, o programa das aldeias socialistas, enquanto configuração política visando à transformação social do campo foi abandonada a partir de julho de 1981 (Decreto n. ${ }^{\circ}$ 81-164), de forma inesperada.

${ }^{167}$ Ver. BOESEN, J. MADSEN, B. \& MOODY, T. na sua obra. Ujamaa Socialism from above.1977. Sustentam que, dessas aldeias se pretendiam ser o instrumento fundamental do desenvolvimento rural, com a sua adequação a planificação fiscal e o enquadramento sócio-espacial das populações rurais, isoladas e desintegradas de qualquer dinâmica sócio-política a nível nacional ${ }^{167}$. No projeto das ujamaa podem-se distinguir dois aspetos que respondem ás exigências mencionadas. Por um lado, trata-se de criar centros rurais de habitat concentrando que viabilizem a planificação econômica nacional em termos de apoios e serviços, minimizando os custos que a dispersão física e social suporia. Por outro lado, a organização social das ajumaa, ao basear-se em novas relações de produção e de poder evitaria o risco de polarizações rurais intermediárias que perturbassem o processo de integração política nacional.

168 Ver. CARDETINI, Onilia. Éléments d'une stratégie d'éco-développement pour lês villages ujamaa de La Tanzanie. 1974.

169 Dado os elevados custos financeiros e técnicos destes programas, de 1963 a 1966 formas criadas apenas 27 centros agrícolas deste gênero, absorvendo a totalidade dos fundos disponíveis. Do ponto de vista econômico, foram rentáveis durante alguns anos, mas que as condições do mercado internacionais deixaram de ser favoráveis estes projetos eu privilegiavam as culturas de exportação e ocuparam as terras mais férteis tornando-se economicamente inviáveis (CASAL, 1996).

${ }^{170}$ Por vezes, as recomendações da Comissão Nacional das Aldeias Comunais iam ao sentido de fornecer apoio familiar, para a sua produtividade aumentassem, as condições de vida melhorassem e a força de trabalho excede pudesse ser canalizada para a produção coletiva. Tratava-se de uma perspectiva, na ótica de resolver tecnicamente o problema político da transição para o socialismo real, segundo o qual a implementação das formas de produção coletiva teria sucesso só e quando elas pudessem emergir da plena realização de modelos anteriores e mais simples (1. ${ }^{a}$ REUNIÃO NACIONAL DAS ALDEIAS COMUNAIS, MARÇO DE 1980).
} 
subalterna, tardia e ambígua nas aldeias comunais ${ }^{171}$. Esse fator deveu-se a concepção e a estratégia das cooperativas agrícolas, quer nos discursos dos dirigentes, quer nas práticas seguidas, primeiro nas "zonas libertadas" e posteriormente ao nível do território nacional já independente, foram apresentados com soluções do recurso, mal formada como dispositivos econômicos, e muito valorizada como fator de organização política ${ }^{172}$. A sua maior ambigüidade resulta da instrumentalização política a que esteve subordinada num processo em que as expectativas econômicas dos camponeses ainda constituíam o seu maior impulso.

Os cooperativistas e cooperativas, ao ser introduzido nas aldeias comunais em Moçambique, foram como uma força suplementar de consolidação das aldeias, em que se, buscava um enquadramento administrativa ${ }^{173}$, na socialização do campo "a luz das experiências", pré-cooperativas ${ }^{174}$, já que elas não concentraram a atividade principal dos membros, nem demonstraram o poder de mobilizar as vantagens de este tipo de propriedade socialista $^{175}$.

Porém, nas aldeias comunais as cooperativas de produção agrícola constituíam ainda, a base para a transformação socialista que se pretende atingir. Para tal, a FRELIMO concebeu em algumas partes do país, apoios técnicos, intervenção estatal para o trabalho cooperativo. Esta cooperativa introduzida no Estatuto de principio era posta em pratica por via administrativa, tornando-se num instrumento privilegiado nas mãos do Estado, o que levou a sua evolução em número. Como mostra o quadro a baixo dos primeiros dados referentes à evolução do número de

\footnotetext{
${ }^{171}$ Segundo Casal, 1996.

${ }^{172}$ Ver. ARAÚJO, Manuel. O sistema das aldeias comunais em Moçambique: transformações na organização do espaço residencial e produtivo. 1988; As aldeias comunais e o seu papel na distribuição territorial da população rural na RPM. 1983.

${ }^{173}$ Uma cooperativa que nasce à sombra de um aglomerado de camponeses organizados segundo um plano político e administrativo fixo, previamente determinado, corre todos os riscos de perder as suas características e especificidades mais genuínas de participação livres e democrática, de repartição igualitária dos produtos, de troca e de comunicação paritária entre os seus membros, de formação técnica e social, de apoio e segurança dos seus membros, enfim, de contributo eficaz para melhoramento da vida material e social (CASAL, 1996).

${ }^{174}$ Referem-se, fundamentalmente, a formas de produção coletivas registradas como cooperativas, embora muitas nunca tenham passado de "machambas coletivas" sem expressão produtiva efetiva (ARAÚJO, 1983).

175 Este sistema de redes de comercialização, escoamento e distribuição de produtos não chegou a ser nem controlado nem reconvertido pela nova economia nacional, desencadeando graves crises de abastecimento. O setor dos intermediários rurais, nomeadamente - comerciantes e transportadores privados -, não foram devidamente acautelados, criando um vazio no funcionamento da economia rural e um obstáculo vital para o processo de transformação socialista. Por outro lado, o Estado moçambicano revelava, com insistência, fraca capacidade de gestão e de eficácia no plano econômico, quer ao nível das infra-estruturas instaladas, quer ao nível dos mecanismos e instituições que ele tinha criado. A crise econômica e social geral iria refletem como é entre aquelas que foram colocadas numa situação "revolucionária" de desenvolvimento e de transformação socialista por intermédio das aldeias comunais e das cooperativas (CASAL, 1996).
} 
cooperativista e cooperativa no período compreendido entre 1977 e 1981.

TABELA 7.

Número de cooperativas 1977-1982.

\begin{tabular}{|l|c|c|}
\hline Anos & Número de cooperativas & Número de cooperativistas \\
\hline $1977-1978$ & 180 & 25000 \\
\hline $1978-1979$ & 300 & 30000 \\
\hline $1979-1980$ & 327 & 32000 \\
\hline $1980-1981$ & 351 & 34469 \\
\hline $1981-1982$ & 375 & 36882
\end{tabular}

Fonte: “Contribuição para o programa da cooperativização do campo". Ministério da Agricultura, Maputo, Maputo, Abril, 1982.

A evolução do número de cooperativistas e cooperativas foi, ao longo dos cinco anos, sempre positiva, embora o crescimento de cooperativistas seja menos pronunciado relativamente ao de cooperativas. Em ambas, a evolução é mais forte nos dois primeiros anos ${ }^{176}$. Em 1981 a média de cooperativista era de 98. Utilizando o documento do Ministério da Agricultura, onde consta, para o ano de 1980-1981, a distribuição de cooperativas e cooperativistas. Na última coluna introduzimos o número de aldeias comunais para facilitar a comparação, embora a data da distribuição das aldeias seja a de 1982.

${ }^{176}$ Ver. COMISSÃO NACIONAL DAS ALDEIAS COMUNAIS - O processo de desenvolvimento das aldeias comunais. 1979. 
TABELA 8.

Número de cooperativas, por província e aldeias. 1977-1982.

\begin{tabular}{l|c|c|c|}
\hline Províncias & Número de cooperativa & Número de cooperativistas & Número de aldeias \\
\hline Cabo Delgado & 28 & 948 & 543 \\
\hline Niassa & 44 & 1715 & 63 \\
\hline Nampula & 29 & 3544 & 260 \\
\hline Zambézia & 64 & 3288 & 39 \\
\hline Tete & 31 & 1202 & 40 \\
\hline Manica & 6 & 280 & 88 \\
\hline Sofala & 25 & 10000 & 47 \\
\hline Inhambane & 16 & 1941 & 139 \\
\hline Gaza & 38 & 7630 & 1352 \\
\hline Maputo & 70 & 2941 & 33469 \\
\hline Total & 351 & 362 & \\
\hline
\end{tabular}

Fonte: GODA “Projeto de ação de cooperativa para 1982”. Mistério da Agricultura.

As cooperativas agrícolas só começarem a ser realmente encorajadas, como dispositivos econômico, no preciso momento em que o movimento das aldeias comunais atingia o seu auge (2 milhões de camponeses aldeãos) e a economia familiar dos aldeões entrava em crise aguda ${ }^{177}$. Esta situação é bem demonstrada no quadro acima, quando mostra o desnível entre o número total de cooperativas e o de aldeias comunais, apenas 1/4 das aldeias dispunham de cooperativas. Este encorajamento ao cooperativismo nas aldeias comunais faz-se por via de ajudas financeiras, administrativas e técnicas por parte do Estado. Um processo que passo por um plano de rentabilidade econômica, onde as cooperativas receberam auxílios financeiros mais significativos $^{178}$.

Um dos documentos explicitando a conveniência da produção cooperativa foi divulgado em 1976 - Estatuto - Tipo das cooperativas de Consumo e Produção, Ministério da

177 A natureza da política preconizada pelo partido incorporava, com tenacidade, a questão das "lutas política e ideológica que deveriam ser empreendidas para organização da produção familiar em forma de produção coletiva nas aldeias comunais" (SECRETARIADO DA PLANIFICAÇÃO ECONÔMICA DO PARTIDO, FEVEREIRO DE 1978).

${ }^{178}$ Ver. CASAL, r Adolfo Yanez . A Crise da Produção Familiar e as Aldeias Comunais em Moçambique. 1988. 
Agricultura ${ }^{179}$. Neste documento a cooperativa é assumida como estratégia de desenvolvimento. "A cooperativa é considerado uma organização socioeconômico de massa, que constitui parte integrante do setor popular da economia nacional. Neste contexto, no entanto, a cooperativa aparece sem autonomia, ficando subordinada ao Estado e à planificação econômica estatal. $\mathrm{O}$ sistema de trabalho, na cooperativa, deve-se basear nos seguintes princípios. Um dos maiores defeitos da produção cooperativa, nomeadamente esta na sujeição que ela tinha na gestão dos administradores e aos imperativos da economia nacional, criando uma diferença entre as áreas planificadas e as áreas efetivamente cultivadas durante cinco campanhas. As diferenças constatadas entre áreas planificadas e efetivamente cultivadas assumem valores ainda mais divergentes quando transpostas para a produção. Assim, no período de 1978-1981 aparecem às seguintes "decalagens" entre a produção planificada e a produção efetiva (em toneladas):

TABELA 9.

\section{Número de áreas planificada e cultivadas por Governo (1977-1982)}

\begin{tabular}{|l|c|c|}
\hline Campanha & Áreas planificadas & Áreas cultivadas \\
\hline $1977-1978$ & ----- & ----- \\
\hline $1978-1979$ & 24257 & 13160 \\
\hline $1979-1980$ & 25857 & 13339 \\
\hline $1980-1981$ & 26234 & 13208 \\
\hline $1982-1982$ & 24702 & 11491 \\
\hline
\end{tabular}

Fonte: Mosca (2005). Legenda: os traços (----) significam que não existem dados.

O papel das cooperativas seria de constituir o núcleo que daria origens á aldeias. A cooperativa de produção era a estrutura econômica básica em que o novo modo de viver das aldeias comunais ${ }^{180}$.

\footnotetext{
179 Três anos após o estatuto-tipo das cooperativas proposto pelo Ministério da Agricultura, a Assembléia Popular aprova a Lei das Cooperativas. Nesta lei, definido a constituição, tipo e formas de organização cooperativa em Moçambique, são contemplados sete tipos de cooperativas, de acordo com os diferentes ramos da atividade econômica: cooperativas de produção agrária, de produção pesqueira, de produção industrial, de produção artesanal, de consumo, de habitação e de prestação de serviços. No seu preâmbulo, a lei, referindo - se às cooperativas de produção agrária, esclarece as suas principais funções nestes termos: "na agricultura - base da nossa economia -, a organização dos camponeses em cooperativas acelera o desenvolvimento das forças produtivas e permite o aumento da produção e da produtividade, facilita o abastecimento dos meios de produção e o escoamento dos produtos

180 É preocupação de o Ministério encarar a cooperativa da produção agrícola como um dos pilares "naturais" do processo de aldeamento, respondendo, aliás, "ás iniciativas de produção coletiva que do norte ao sul do país
} 
As cooperativas participam, assim, na socialização progressiva do campo, constituindo, designadamente, um elemento fundamental de consolidação das aldeias comunais. O regulamento da lei das cooperativas, no que concernem as cooperativas de produção agrária, só seria aprovado em outubro de $1981^{181}$, neste regulamento 'Estatuto - Tipo' das Cooperativas de Produção Agrária, as referências ás aldeias comunais teriam as cooperativas de produção agrária como derradeiro dispositivo com que os responsáveis poderiam ratificar um processo de desenvolvimento rural $^{182}$. O estatuto pretendia adequar-se á realidade histórica moçambicana, referindo-se á experiência da produção coletiva das zonas libertadas e á situação de exploração colonial do passado, que desenvolveram sentimentos de solidariedades sociais e a diferente forma de ajuda mútua, entre as populações rurais, poderiam constituir fator importante de dinamizar a coesão das cooperativas ${ }^{183}$. Por outro lado, a legislação contida dos modelos experimentados nos países socialistas, instrumentalizada ideologicamente com os princípios do “socialismo científica" e subordinada aos objetivos políticos gerais do Estado ${ }^{184}$.

Porém, a reestruturação econômica rural com base nas cooperativas agrícolas teve características diferentes na região norte e sul de Moçambique, marcadas pela distinção quanto às origens e as motivações. Na região sul de Moçambique, principalmente nas províncias de Maputo e Gaza, a grande maioria das aldeias foi criada nos anos 77-78, por ocasião das inundações dos rios Incomáte e Limpopo. As populações foram transferidas dos vales, onde viviam cultivando a terra de aluvião para as margens de "secano" e de terras arenosas, mais elevadas, onde foram concentradas em aldeias comunais ${ }^{185}$. As cooperativas de produção foram,

espontaneamente se criam e que serão os primeiros passos para a generalização das aldeias comunais em todo o país (CASAL, 1996).

${ }^{181}$ Precisamente quando o movimento das aldeias comunais começa declinar e a ser objeto de produção, da crise social e a inviabilidade econômica em que estavam mergulhadas.

182 Segundo esta única referencia da lei ás aldeias comunais, a cooperativa faz parte do processo de socialização rural, como fator de consolidação das aldeias comunais; isto é, o processo mantém-se invertido, demonstrando, mas uma vez, a justaposição de estratégias, o domínio político-ideológico e a negligência das análises sobre a realidade concreta (ARAÚJO, 1983).

${ }^{183}$ Nas sociedades rurais moçambicanas existem também mecanismos de diferenciação social interna, de inibição ou de subordinação estatuário muito marcado, que ao abrigo das cooperativas podem muito facilmente ser instrumentalizados e reativados, permitindo a uma maioria de notáveis linhageiros controlarem e gerir os benefícios coletivos e os Estados ao seu favor. Para os responsáveis políticos, nem aqueles recursos nem estes obstáculos foram objeto de preocupação.

${ }^{184}$ Para mais informações ver, CASAL, Adolfo Yanez. Nas obras intitualdas. Discurso Socialista e camponês africanos: Legitimação político-ideológico da socialização rural em Moçambique (Frelimo, 1965-1984). 1991;A Crise da Produção Familiar e as Aldeias Comunais em Moçambique. 1988; ANTROPOLOGIA E DESENVOLVIMENTO. As Aldeias Comunais em Moçambique. 1996.

${ }^{185}$ Nas três aldeias comunais da província de Maputo - aldeias Eduardo Mondlane, 3 de Fevereiro e Maguiguane - a área de produção coletiva ficava localizada no vale, a mais de $7 \mathrm{Km}$ da aldeia, em terras de pastagens, "farmas" 
em alguns casos, precedidas por experiências irregulares e espontâneas de produção coletiva nos próprios locais de habitat disperso (o vale); mas a concentração das populações em aldeias comunais viria alterar essa dinâmica, imprimindo ao movimento coletivo, iniciado logo a seguir á independência, um figurino de uniformidade e de obrigatoriedade política decorrente do modelo e da implantação das aldeias. Houve casos - aldeias Eduardo Mondlane, 3 de Fevereiro (Manhiça-Maputo) e 1. de Maio (Gaza) - em que a "machamba" do povo foi convertida em cooperativa da aldeia; manteve a mesma localização, mas mudou de natureza e de funcionamento $^{186}$. Uma das características de que se reveste a origem da produção cooperativa moçambicana, esta nos desastre econômico, causadas pela falta da cobertura técnicaadministrativa na integra pelo Estado. As condições fornecidas para alugar os tratores estatais, a concessão de créditos e o alargamento desmesurado das áreas de cultivo. Além das pressões sociais e políticas exercidas sobre os cooperativistas, desequilibraram as capacidades locais comunitárias de gestão e de trabalho disponíveis ${ }^{187}$.

A criação da aldeia comunal (1977) e a transformação da "machamba do povo" em cooperativa, o processo de socialização passou a ser "empurrado" pela administração distrital. Assim sendo, para impulsionar uma maior produção foram introduzidos "os avanços" uma espécie de salário mínimo pago a cada participante por dia de trabalho na cooperativa. Este processo de "avanço" foi semelhante em todas as aldeias comunais da região sul, onde tinham

abandonadas por colonos ou mesmo em terras de cultivo familiar, posteriormente anexadas a cooperativas. Nas aldeias situadas na província de Gaza - aldeia 3 de Fevereiro, Julius Nyerere, Carlos Prestes e $1^{\circ}$ de Maio - a área de produção coletiva de cada aldeia está mais próximo, mas a sua origem e composição é semelhante: "farmas" abandonadas, pastagens e campos familiares (CASAL, 1996).

${ }^{186} \mathrm{O}$ desequilíbrio que aparece entre áreas planificadas e cultivadas é bem significativo das expectativas irrealistas com quem foram elaborados os planos agrícolas nacionais. Assim, no triênio de 1979-1981 índice médio de realização do plano agrícola para setor cooperativista foi apenas de $40 \%$, com uma redução anual de $10 \%$.

${ }^{187}$ Entre a população que viria a ser concentrada na aldeia comunal de 3 de Fevereiro (Gaza), o trabalho coletivo na "machamba do povo" anterior à cooperativa - lavra e preparação da terra - era realizado com as charruas dos próprios residentes. A área cultivada não excedia os 5 há. A participação nas atividades de sementeiras sacha, etc., decorria espontâneo e até festivamente. A produção era diversificada - arroz, cebola, tomate, alho, alface, etc. a comercialização, no entanto, não era garantida e os produtos chegavam a estragar-se. Na primeira campanha (19771978), a superfície lavrada já foi de 25 ha (20 ha de arroz e 5 há de cebola); em 1978 foi anexado à cooperativa um bananal abandonado de 5 ha. Alugaram-se tratores e as sementes foram compradas. Houve um grande déficit de mão de obra para a sacha e, sobretudo para a cifra do arroz; a produção dessa campanha ficou reduzida a pouco mais de uma dúzia de sacos de arroz e a 1 ha de cebola. As dividas contraídas (aluguer de tratores e compara de sementes) ascenderam a 70 contos. Na campanha de 1978 a superfície lavrada foi apenas de 10 ha de milho e 5 de hortícolas. As despesas foram mínimas, mas as inundações desse ano não permitiram fazer as sementeiras do milho e as dividas aumentaram. Na campanha de 1979 o plano elaborado pela Administração foi cultivar 50 ha de arroz. O estado concedeu, então, um crédito de 100 contos á cooperativo para saldar as divida e fazer face ás despesas dessa campanha (Ibidem). 
cooperativas foi semelhante ${ }^{188}$.

Em algumas aldeias, teoricamente, todos os aldeões eram considerados membros da cooperativa, sendo destacado para o trabalho da cooperativa um indivíduo por cada família três vezes por semana. A obrigatoriedade do trabalho coletivo fazia lembrar a muitos aldeões o trabalho obrigatório no período colonial. A grande preocupação dos aldeões continuava a ser após dois anos de vida na aldeia, o restabelecimento da sua base econômica. Os campos familiares ficavam longe, os rendimentos eram precários e a loja coletiva (cooperativa de consumo) não abastecia com regularidade ${ }^{189}$. Assim sendo, muitos membros da cooperativa preferem integrar-se nas empresas estatais como assalariados. Outros, após receber os "avanços" de um mês, retiram-se á procura de produtos alimentares noutras zonas da região melhor abastecidas.

A participação dos aldeões nos setores estatais e cooperativo se tivesse mostrado economicamente pouco rentável, os aldeões faziam as suas escolhas, privilegiando as atividades produtivas do setor familiar. $\mathrm{O}$ atrativo pelo trabalho assalariado nas empresas estatais também perdia impacto dada a profunda crise do abastecimento; comprar produtos de primeira necessidade no mercado ou "cantina do povo" era cada vez mais difícil e complicado. Porém, a orientação política em relação ao processo de socialização rural considerava a produção familiar como um grave obstáculo à cooperativização, pelo que se impunham estrategicamente no sentido de desviar a população rural das atividades produtivas familiares ${ }^{190}$.

\footnotetext{
188 Ibidem.

${ }^{189}$ Nas aldeias Julius Nyerere, Carlos Prestes e $1 .^{\circ}$ de Maio a experiência de cooperativização é, nas três, muito semelhante, nas suas origens, processos e resultados. Tratava-se de aldeias com densidade populacional muito elevada, as terras para a produção estavam bem localizadas, eram abundantes e boas qualidade. Em qualquer das três casos, as populações já tinham tido experiências de trabalho coletivo nos seus respectivos habitat disperso. Nas primeiras campanhas a resposta dos aldeões à mobilização cooperativa foi majoritária, mas significativa em termos de participação. A partir de 1978-1979 o Estado decidiu intervir diretamente, disponibilizando apoios materiais, logísticos e financeiros, na tentativa de acelerar o processo de cooperativização nas três aldeias comunais. As administrações distritais e os diretores das "machambas" estatais assumem o cargo das cooperativas, exercendo sobre elas a mesma gestão e poder que exerciam sobre as administrações distritais e sobre as empresas estatais. As principais razões que estiveram na base de um absentismo tão pronunciado foram, em primeiro lugar, a ausência de salários (avanço) aos cooperativistas: por outro lado, a população, nos ciclos agrícolas de ponta - sementeira e colheitas - acode em massa às suas "machambas" familiares, acontece, ainda, que muitas famílias, durante esses ciclos, regressam ao vale distante, onde mantinha os seus campos, permanecendo ai para além desses períodos. Em outra, circunstância que, sem dúvida, teve muito a ver com o absentismo cooperativismo nestas aldeias, como a caso da falta de coesão e de entendimento (WUYTS, 1978).

190 Uma desta estratégia, desenvolvida na região do Baixo Limpopo, consistia em integrar no setor estatal e cooperativo uma parte das terras pertencentes ao setor família. Numa área total de exploração de forma parcelar do período colonial através de 'colonatos' rurais, foram recuperadas e concentradas numa única unidade de 4500 ha para o cultivo de arroz, 750 ha para cultivo de trigo e 250 ha de banana; estimava-se que esta unidade estatal tivesse
} 
Partindo do recenseamento realizado em 1978 (primeira campanha de vacinação) permitiu-se identificar a população ativa em 13 das aldeias comunais em um número aproximadamente de 34920 indivíduos. Partindo desta população a unidade estatal deveria fazer o recrutamento de mão de obra agrícola necessária para a grande empresa agrícola. O programa estatal do médio Limpopo na região do Chókwé possuía condições favoráveis para o desenvolvimento da socialização. Nesta região, havia infra-estruturais, tradição de produção intensiva e alguma capitalização dos sistemas produtivos, aldeias construídas e localizadas numa zona politicamente favorável ${ }^{191}$.

Essa região a grande maioria dos agricultores portugueses do colonato saiu do país, tendo-se criada uma grande empresa estatal que controlou a quase totalidade do sistema de regadio com cerca de 22000 hectares, com pecuária, várias indústria alimentares (lacticínios, massa e concentrado de tomate, salsicharia e enchidos de carne, descaroçamento de arroz), a gestão imobiliária de várias aldeias dentro do perímetro irrigado, etc. Foi atribuído o nome de Complexo Agro-Industrial do Limpopo (CAIL) e organizado à imagem dos sovkolz soviético e dos complexos agroindustriais de outros países socialistas. O CAIL deveria ser o exemplo da empresa estatal socialista: grande em dimensão, com infra-estruturas que permitiam a intensificação produtiva, com aldeias (que se deveriam transformar em aldeias comunais), possuía uma agro-indústria associada com a produção local bastante desenvolvida na época e uma elevada percentagem da população da zona possuía um nível de acumulação e de desenvolvimento cultural diferente da maioria das regiões do país ${ }^{192}$.

A modernização do campo (entendia como sinônimo de mecanização, quimização, intensificação produtiva em forma socialista de produção) e a elevada produtividade, eram consideradas necessárias para a socialização do campo ${ }^{193}$. Para concretizar os seus objetivos, os camponeses, expropriados com a construção do colonato na década dos anos 1950, mantiveramse nas terras altas, nas margens do vale ${ }^{194}$. Em 1979 as diretivas foram emanadas para os ex-

aindaumacapacidade de produção de 835000 litros de leite e de 38000 de carne; dispunha de um parque razoável de máquinas agrícolas e utilizava 35 estações de bobagem da água para a rega do arroz e hortícolas (CASAL, 1996).

191 Samora Machel era natural de Chókwé - aldeia de Xilembene, e Eduardo Mondlane e Joaquim Chissano nasceram no distrito vizinho de Chibuto, além de outros altos responsáveis da FRELIMO (MOSCA, 2005).

${ }^{192}$ Em conseqüência do modelo de colonização, da emigração para RAS e do colonato, o Chókwé era uma região onde o desenvolvimento do colonato estava em fase adiantada de diferenciação social, a integração no mercado era elevada e a acumulação econômica tinha-se iniciado há décadas.

${ }^{193}$ Esta é a concepção da modernização da agricultura do socialismo ortodoxo refletido no texto clássico de Kautsky, a questão agrária.

${ }^{194}$ Os colonos portugueses que permaneceram no local foram majoritariamente concentrados em zonas do regadio 
colonos e camponeses de forma seguinte para que não percam as suas terras nesta região, deveriam cultivar áreas superiores 1 (hectare), os camponeses não poderiam ter perdido a declaração da dividas, deveriam viver exclusivamente da agricultura, os camponeses não poderiam ficar fora do distrito, nem os trabalhadores ou ex-trabalhadores do CAIL ou de qualquer cooperativa de produção. Também ficavam, perdiam a outra parte da terra os camponeses que cultivava uma parte das machambas (caso fosse superior ha). Assim como, as machambas não podiam ser herdadas.

O CAIL, que se dedicava principalmente à produção do arroz (mais de 80 por cento da superfície trabalhada), fez-se esforços para aumentar a produção por hectare à base de dosagem elevadas de fertilização. Assim sendo, os grandes investimentos foram feitas em maquinarias, ceifairas-debulhadoras, centenas de tratores; chegaram equipes técnicas dos países socialistas com dezenas de profissionais de varias áreas; principalmente não existiam restrições financeiras; o apoio político era total. Antes da aquisição dos equipamentos na CAIL aconteceu um episódio, triste nos primeiros anos, antes de realizarem grandes investimentos em maquinarias, existiram fortes dificuldades para a colheita do arroz que levaram a intervenção do Presidente da República numa grande "mobilização" da população dos distritos vizinhos ao Chókwé195.

As diferenças inversas no emprego e na assiduidade dos trabalhadores ao longo do ano são devidas às necessidades sazonais que se fez sentir em ambos os setores de produção, o familiar e o estatal, o que faz aumentar o número de jornadas em determinadas épocas do ano. Segundo os dados anteriores, os 285 indivíduos contratados em duas aldeias trabalharam durante o ano na unidade estatal, em média, 60,9 dias cada um. Ora, fazendo uma extrapolação para as necessidades laborais de toda a empresa nos diferentes blocos, estimadas, segundo o plano de 1978-1979, em 1339655 jornadas de trabalho, o que seria necessário contratar 22000 aldeões, à razão de 61 dias cada um por ano ${ }^{196}$. Esta participação dos camponeses não se libertaria da

com piores terras, onde possui problemas de salinização dos solos, agravado por uma deficiência na drenagem. Os colonos moçambicanos (vistos como novos ricos) ou Kulaks moçambicanos (camponeses que, através de um processo de acumulação e de diferenciação social, formaram estratos de rendimentos mais elevados), foram simplesmente marginalizados e muitos se transformaram em trabalhadores do CAIL (MOSCA, 2005).

195 De acordo com Hermele (1987), foram orientados sete distritos para cada uma delas fornecer 5000 homens ao CAIL durante um mês, para o trabalho não pago; os funcionários públicos prestaram trabalho 'voluntário' transportado em autocarros desde Maputo e Xai-Xai. O grosso dos trabalhadores veio do Bloco n. ${ }^{\circ} 1$ da unidade estatal recrutou nas aldeias comunais, como por exemplo, no Patrice Lumumba e Salvador Alende 285 trabalhadores - 173 homens e 112 mulheres -, numa população aldeã de 5866 pessoas.

${ }^{196}$ Isto significa que, nas circunstâncias de variabilidade sazonal por parte da empresa e de assiduidade por parte dos aldeões constatadas no quadros dos, a unidade estatal em estudo teria apenas uma capacidade real de absorção de 
necessidade de recorrer a outras fontes de rendimento, como seria o caso da produção familiar, para garantir a base alimentar para o resto do ano ${ }^{197}$.

A questão da gestão de terra era uma fonte permanente de conflito entre aqueles que apontavam para a valorização dos produtos camponeses organizados em cooperativas, e os apologistas da estatização que apoiavam a centralização dos recursos em amplas unidades de produção controladas pelo poder público. As reduções das terras familiares, imposta pelo Estado ao setor familiar, provocaram uma maior adesão dos aldeões à produção coletiva e estadual, agravando cada vez mais as contradições no meio social. Porém, uma das questões discutidas era a nacionalização da terra que era exigida tanto pelas famílias ou comunidades, que queriam a sua restituição às populações que tinha sido espoliada pelas explorações coloniais, pelos que consideravam isso devia ser a primeira questão da gestão pública dos recursos a ser resolvida. Este conflito foi regulamentado pela constituição, de forma que a terra fosse à propriedade de Estado, tanto como os recursos situados no solo e no subsolo, nas águas territoriais e na plataforma continental de Moçambique e, o Estado determinou as condições do seu uso e aproveitamento $^{198}$. Construindo assim as suas linhas políticas econômicas, dentro das funções de um "partido-estado", a FRELIMO centralizou tanto, as questões da organização do poder e das populações.

Na zona norte de Moçambique especificamente, na região de Cabo Delgado e Nampula. Os processos de cooperativização tiveram uma dinâmica diferente quanto às oportunidades. Uma em que o processo de cooperativização se mantinha numa situação de abandono e de marginalização por parte do Estado - apoios financeiros e insumos - e dos serviços administrativos - orientações, apoios técnicos, formação e informação. Esta situação correspondia àquelas aldeias e cooperativas localizadas fora das áreas de influência das grandes empresas estatais produtoras de algodão. Outra dinâmica diz respeito àquelas aldeias cooperativas que se situam nas proximidades dessas unidades estatais, recebendo delas e da administração distrital os apoios técnicos, financeiros e logísticos mais diversificados ${ }^{199}$.

A relação área/cooperativa/cooperativista é muito diferente nas duas províncias; em

mão de obra agrícola de um pouco mais da metade de toda a população ativa das 13 aldeias comunais sob o seu controlo (35 000) durante 61 dias por ano e um salários de 50 escudos por dia de trabalho (CASAL, 1988).

197 Ver. Hermele (1987).

198 Porém, na constituição o artigo nove, previa uma planificação econômica do Estado promovendo a garantia do aproveitamento correto das riquezas do País e sua utilização em beneficio do povo moçambicano (CONSTITUIÇÃO DA REPÚBLICA DE MOÇAMBIQUE, 1975).

199 Ver. Casal (1996). 
Cabo Delgado a área média por cooperativa era de 9 e 0.18 , respectivamente enquanto em Nampula esta relação subia para 30 e 0,61. E quanto ao meio de produção utilizados, querem alugados, quer próprios, apenas uma cooperativa em Cabo Delgado e oito em Nampula utilizam tratores. Em Nampula a aldeia comunal Josina Machel - distrito de Ribaue - possui um trator para uma área cultivada de $10 \mathrm{ha}^{200}$. Porém, o apoio estatal materializados no lugar de tratores e dirigido, quase em exclusividade, para as cooperativas de Nampula, deve-se a questão de estarem localizadas nas proximidades das empresas estatais de algodão, sendo o cultivo de algodão a sua principal ocupação cooperativa. Nesta região, afetada pela mosca do sono, não existia gado bovino e a tração animal. O trabalho agrícola nas cooperativas foi um dos casos já mais visto por ela ter como o seu principal material de trabalho a enxada de cabo curto ${ }^{201}$.

A introdução do trator nas cooperativas de Nampula pouco modificou os índices de produtividade. Comparado a relação existente entre números de cooperativistas e de hectares cultivados no distrito de Mecufí, onde nenhuma das 13 cooperativas alugou tratores, e nos distritos de Chiúre e Ribaue, onde o aluguer de tratores existiu, a diferença é mínima: no primeiro caso essa relação é de 0,1 e no segundo caso é de 0,3 . Isto quer dizer, que na prática, a intervenção do trator, representando teoricamente uma produtividade de 10-20 vezes superior à do trabalho manual, não teve significado algum. A produção mais cultivada, por ordem de importância, é: algodão, milho, mandioca, girassol, mapira, gergelim, amendoim, feijão, arroz, tabaco, caju e fruta. O algodão - produto de exportação - é predominante em toda a área ${ }^{202}$. A rentabilidade global do setor cooperativo tem índices é muito inferiores aos do setor familiar ${ }^{203}$. Em termo de rendimento por hectare, nas quatro principais culturas para a campanha de 19801981 os valores médios atingidos são sempre inferiores aos valores nacionais obtidos do setor familiar, como a seguir se discrimina na tabela:

\footnotetext{
${ }^{200}$ A aldeia de Natala e a Unidade de Moçambique, ambas localizadas no distrito de Mecuburi, possuíam um camião cada uma (CASAL, 1996).

${ }^{201}$ Ver. Casal (1996).

202 Ibidem

${ }^{203}$ Se nos limitarmos à cultura do algodão, no setor familiar 1 ha rende 13,4 sacos, enquanto no setor cooperativo 1 ha não ultrapassa os 5,5 sacos. Por outro lado, a área média unitária cultivada no setor familiar é um pouco superior a 1 ha, ao passo que nas cooperativas a média de terra cultivada por cooperativista é de 0,8 há (CASAL, 1996).
} 
TABEL A 10.

\section{Setor corporativo e setor familiar na campanha de 1980-1981}

\begin{tabular}{|l|c|c|}
\hline \multirow{2}{*}{ Produtos } & \multicolumn{2}{c|}{ Toneladas por hectare } \\
\cline { 2 - 3 } \multicolumn{1}{c|}{} & Setor cooperativo & Setor familiar \\
\hline Milho & 0,410 & 0,550 \\
\hline Grroz & 0,550 & 0,760 \\
\hline Algodão & 0,200 & 0,500 \\
\hline
\end{tabular}

Fonte: Casal (1996).

Em geral, os rendimentos de produção cooperativos e familiares foram utilizados como fundo coletivo sem um fim determinado, para compra de equipamentos, abastecimento da cooperativa de consumo, pagamento de dívidas contraídas com aluguer de tratores, compra de sementes, etc ${ }^{204}$. Uma situação que se repete de aldeã para aldeia é a de desvios freqüentes dos rendimentos da cooperativa de produção, quer em produtos quer em dinheiro, por parte dos funcionários administrativos e dos agentes da comercialização do algodão; os aldeões são burlados impunemente nas operações de peso, medida e preço praticado. Nesta região de Moçambique o processo de cooperativização tem características próprias. A sua especificidade provém da herança colonial do cultivo do algodão, que até os anos 60 era uma cultura obrigatória para todos os camponeses. As aldeias comunais e as cooperativas nelas inseridas fazem lembrar aos camponeses as concentrações algodoeiras e os aldeamentos do período colonial. A grande diferença talvez resida na fraca capacidade do Estado moçambicano em fornecer os apoios que esta cultura precisa para ser rentável: renovação dos campos, seleção e entrega das sementes e pesticidas, assim como um abastecimento regular de produtos de primeira necessidade para tornar atrativa a comercialização do produto ${ }^{205}$.

${ }^{204} \mathrm{O}$ abastecimento da cooperativa de consumo a partir dos rendimentos da cooperativa de produção foi um mecanismo desenvolvido em duas aldeias, a de Napi e a de Unidade de Moçambique: os responsáveis destas duas cooperativas decidem abastecer a cooperativa de consumo com o dinheiro obtido na venda do algodão da cooperativa de produção. Os aldeões, membros ou não membros da cooperativa de produção, compram os artigos da cooperativa de produção, primeiro como produtores-abastecedores e segundo como compradores-consumidores do seu próprio produto. É uma estranha e enganosa forma de realizar lucros que só aos responsáveis das cooperativas beneficia. $\mathrm{O}$ setor, que alimenta este ciclo de desvios, é o familiar, que, além de constituir a base econômica dos agregados, contribui para o enriquecimento dos responsáveis da aldeia (CASAL, 1988).

${ }^{205}$ Ver. WUYTS, Marc. On the Question of Mechinization of Mozambican Agricultural Today: Some Theoretical 
Estado promoveu projetos ambiciosos de aldeãs comunais modelo sem respeitar a dinâmica e as capacidades dos próprios aldeões disponibilizando fatores de produção sem explicar aos camponeses onde terminavam os subsídios e começavam os empréstimos a seriam reembolsados; o Estado ignorou que a base econômica dos aldeões reside na produção familiar e que esta tinha de ser absolutamente respeitada quanto a ciclos, diversidades e disponibilidade em mão de obra ${ }^{206}$. Esta situação e ilustrada no setor cooperativo da província de Gaza na campanha 1981-1982:

\section{GRÁFICO 4}

\section{Rendimentos e Investimento das Empresas Estatais}

(Campanha de 1981-1982, nos Distrios de Gaza, Limpopo, Chibuto, Bilene, Madjacaze, Massungir, Guijá)

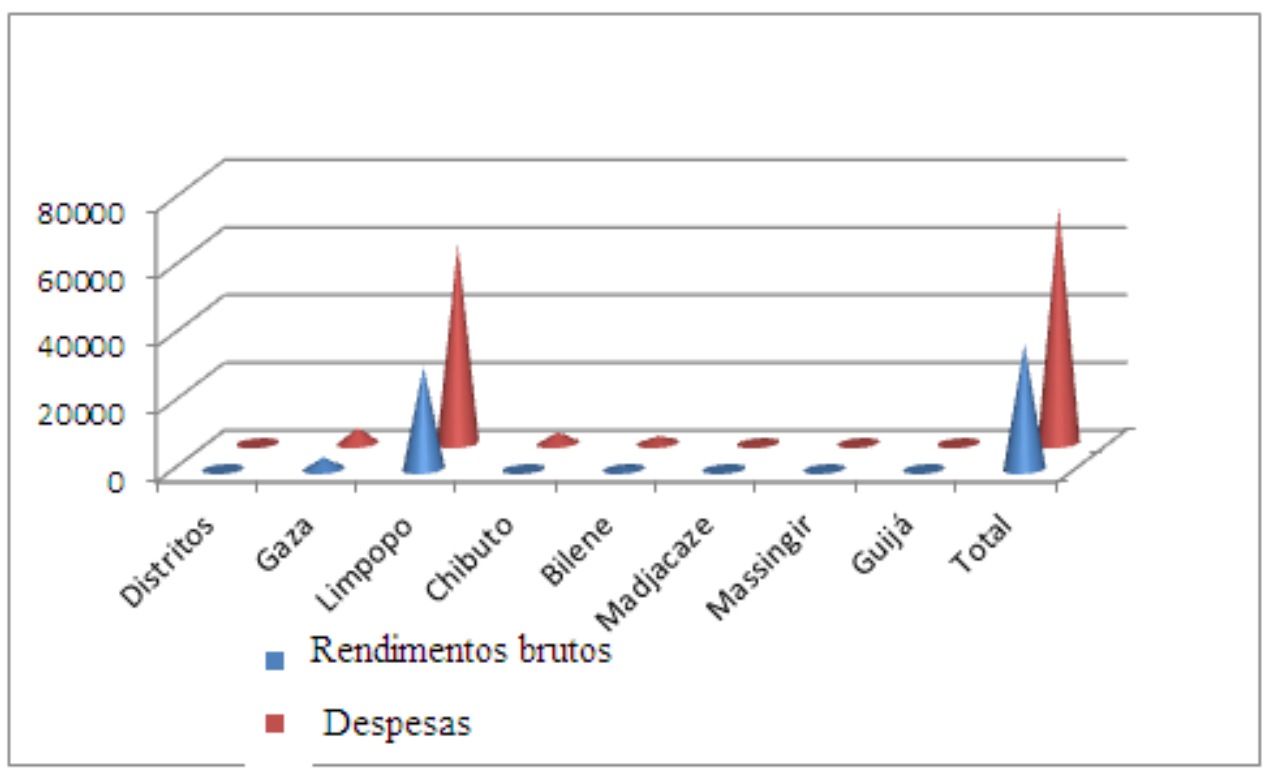

Fonte: Informação da Direção Provincial da Agricultura.

A situação ilustrada no gráfico que expõem a rentabilidade do setor cooperativo nesta campanha foram semeados 5564 ha, obtendo rendimentos brutos de 37162 milhões de meticais.

Comments. Maputo, CEA. 1979.

${ }^{206} \mathrm{O}$ processo conduzido com precipitação de ignorando às condições sociais das populações locais teve uma eficácia inversa à pretendida. Os camponeses não o assimilaram, e como estratégia de socialização, esgotou-se no seu inicio, deixando atrás de si uma memória que se confunde, nas brumas da história, com as práticas da exploração algodoeira colonial. Porém, a monocultura do algodão foi período colônia uma das culturas obrigatórias em que o grau de exploração mais se fez sentir entre os camponeses daquela região, quer em moldes de produção familiar, quer como trabalho assalariado. Em ambos os casos a produção algodoeira era feita em condições de marginalidade absoluta relativamente ao seu processo técnico. $\mathrm{O}$ culto do algodão, agora produzido noutros moldes, mas sujeito igualmente aos ditames administrativos e aos imperativos da economia nacional fazia-lhes lembrar, insidiosamente, que se tratava de uma cultura de triste memória e de fraco proveito (CASAL, 1996). 
As despesas totais atingiram os 69719 milhões. O saldo negativo esteve próximo dos $50 \%{ }^{207}$. Nos sete distritos da província, apenas num o de Majacaze, os custos de produção foram inferiores aos rendimentos.

Na Província da Zambézia também segundo dados da Direção de Agricultura, existiam em 1980-1981, nos quatro distritos; Gurue, Ile, Namaroi e Alto Molocoe, cerca de 20 cooperativas e 1000 cooperativistas, aparam uma população de cerca de 120000 famílias. Das 20 cooperativas, 13 funcionavam sob a influência do setor de produção estatal. Recordamos que o problema base da socialização rural residia num duplo processo desarticulado e implantado separadamente, invertendo completamente a dinâmica social: o processo das aldeias comunais e o das cooperativas. Em conseqüências, as aldeias comunais viriam a constituir aglomerados humanos, formas de organização espacial sem conteúdo nem dinâmica, isto é, sem uma base econômica própria que pudesse sustentar as diferentes estruturas ${ }^{208}$. O balanço global da experiência das cooperativas entre (1976-1982) negativa, podendo destacar, em maior dos locais em que se experimentaram as cooperativas a reação dos aldeões, ao fim da primeira campanha, deixava de ser expectativa e convertia-se em absentismo geral, traduzindo uma contestação mal dissimulada. Nos últimos anos, face á situação de desagregação social originada pelo impacto da concentração habitacional, agravada por calamidades naturais freqüentes, e agonizada pela expansão constante do terrorismo armado praticado pelo Movimento de Resistência Moçambicana, as campanhas e os apoios à cooperativização no seio das aldeias comunais multiplicaram-se, por forma a garantir uma base econômica mínima que invertesse a instabilidade social e minorassem a crise alimentar entre as populações alde $\tilde{a}^{209}$.

\footnotetext{
207 Ver. Casal (1996).

${ }^{208}$ Segundo Negrão (1991), a exemplo, da província de Tete, no distrito de Angónia, uma das zonas mais férteis de Moçambique, existia, em 1982, 16 cooperativas de produção agrícola com um total de 403 cooperativistas. O crédito total utilizado na campanha de 1980-1981 foi de 267927 meticais (dinheiro moçambicano). As dividas, no fim da campanha, totalizavam 136404 meticais. Na campanha seguinte (1981-1982) o crédito concedido ascendeu a 2478407 meticais, elevando as dividas acumuladas para 3419668 meticais.

${ }^{209}$ Mas os recursos do Estado iam sendo cada vez mais precários, ao mesmo tempo em que os diversos e a má gestão dos apoios e créditos concedidos se generalizavam. Optou-se, então concentração dos recursos nas chamadas cooperativas-piloto: um programa que visava demonstrar, em condições "ideais", a consistência de um projeto de cooperativização, tornado inviável em condições "normais". O programa é lançado em 1982, prevendo-se em cada distrito do país a criação de uma cooperativa-piloto, com funções especificas, tais como ser o centro difusor e de formação para as restantes cooperativas da área e demonstrar, na prática, a superioridade da produção coletiva (CASAL, 1988).
} 


\section{VII-CAPÍTULO \\ Plano Estatal Central (PEC)}

Este capítulo, intitulado, Plano Estatal Central (PEC), objetiva mostrar como a FRELIMO consolidou a posição socialista nas diretrizes econômicas. Especificamente, apresentou o PEC, como o primeiro instrumento legal da economia socialista moçambicana. Assim sendo, este capítulo esta subdividido em três pontos: O primeiro é denominado organização econômica, em que, procura mostrar como estava organizada e planejada o desenvolvimento do primeiro plano socialista em Moçambique. Para tal, espelha as medidas de ajuste econômico impostas pelo plano. O segundo ponto, com o tema, gestão das empresas estatais, tem como objetivo mostrar como era à gestão planejada de algumas empresas estatais e as suas prioridades no desenvolvimento econômico do socialismo moçambicano. O terceiro com o tema, características das empresas estatais. Este ponto procura caracterizar o processo de produção nas empresas estatais organizadas no PEC. Nesta perspectiva da construção do socialismo faz uma abordagem partindo de algumas empresas industriais e agrícolas de grande dimensão e consideradas importantes para a economia socialista.

\subsection{Organização Econômica}

Neste tópico, procuramos mostrar como estava organizada e planejada o primeiro plano socialista. Para tal, espelha as medidas de ajuste econômico impostas pelo plano. Um processo que começou estrategicamente a ser desenhada em 1976, com a instrumentalização da direção e gestão econômica, levado a cabo com apoio de técnicos das Nações Unidas ${ }^{210}$. Como fim, de apresentar um programa de emergência à comunidade internacional, para aquisição de financiamentos necessária à funcionalidade do Estado. Moçambique procurou, também, assegurar apoio militares e civis assessorado por países como; cubanos, União Soviética e, sobretudo alemã orientais, bem como procurou manter relações econômicas voltadas essencialmente para com os países ocidentais.

A justificativa era da impossibilidade de Moçambique de emancipar a produção e o

${ }^{210}$ Com objetivo principal de "estimular as necessidade de ajuda internacional decorrentes da aplicação das sanções" á Rodésia (Mosca 2005). 
comercio externo e as estruturas herdadas do colonialismo ser limitados em termo do volume de ajudas econômicas ${ }^{211}$. Assim como, era necessário minimizar os efeitos da nacionalização anunciada sem capacidades administrativas e técnicas para que a universalização dos serviços fosse acompanhada de melhorias na qualidade. Os gastos sociais era um pesado fardo para o orçamento público, que tinha o financiamento da banca estatal, através da emissão de moeda e da acumulação da divida pública ${ }^{212}$. Para a consolidação dos objetivos de reestruturação e programação das atividades do Estado é realizado em Fevereiro de 1977, o Terceiro Congresso da FRELIMO ${ }^{213}$.

Porém, o Congresso tomou como o ponto de partida, a oposição entre a revolução e o modo de produção colonial-capitalista e o dito modo de produção feudal. Uma grande discussão que procurava negar o caráter do capitalismo colonial portuguesa e a sua burguesia em Moçambique. O país era o fruto da resistência secular e da luta heroica e vitoriosa do Povo Moçambicano, conseguido sob a direção da FRELIMO, contra a dominação da colonização portuguesa, onde o imperialismo era um problema, como refere-seprofessor Mazzeo: “o elemento colonial em suas estruturas genética integra um amplo combinado e desigual processo de acumulação de capitais e de objetivação do capitalismo" (2015. p, 130).

Deste modo, o sistema colonial com sua particularidade especifica da acumulação capitalista, estruturaram determinadas formas de pensamento defendido na Constituição da Republica Popular de Moçambique de 1975, nos seus artigos 1 e 2 que preconizava que, Moçambique era um Estado de democracia popular livre de exploração de homem pelo homem, com um poder pertencente aos operários e camponeses. Entretanto, a constituição nos seus artigos 4 e 6 destaca como objetivo fundamental a eliminação das estruturas de opressão e exploração coloniais e tradicionais e da mentalidade que lhes são subjacentes assim como a edificação de uma economia independente ${ }^{214}$.

\footnotetext{
211 Ver. Visentini (2012).

212 A crise econômica não permitiu que a saúde e a educação

${ }^{213}$ Mosca (2005) num clima ainda de uma «FRELIMO vencedora» da guerra contra o colonialismo foi um momento histórico importante em que, pela primeira vez, a FRELIMO como o representante da Sociedade moçambicana se reunia em solo pátrio já libertado, para, em clima de entendimento, consertar as linhas gerais de desenvolvimento e definir ações prioritárias. Dois aspectos assumem, no entanto, particular relevância na configuração socialista da nação moçambicana. Em primeiro lugar, um princípio de natureza político-ideológica transforma oficialmente a FRELIMO num partido político, único, ao qual se subordinam todos os outros órgãos da soberania nacional. Em segundo lugar, o congresso elabora e aprova as diretivas econômicas e sociais que definem as orientações em matéria de política econômica.

${ }^{214}$ Porém, a constituição, tomada a agricultura como base e a indústria como fator dinamizador e decisivo, dentro de
} 
O poder conquistado pela FRELIMO representaria à única opção do povo, porque possuíam uma maior capacidade de mobilização e de influenciar a população a aceitar os fundamentos teóricos e interpretativo marxista ${ }^{215}$. A FRELIMO introduziu diretamente o socialismo, com base nos novos horizontes teóricos africanos, incorporando as analises conceitual de Marx e Lenin para definir as diretivas econômicas e sociais. Um projeto de sociedade defendido com a tese da centralidade e planificação rumo ao desenvolvimento do socialismo. Para tal, se deveria dar um salto sem passar pela fase dita intermediária no caminho para o socialismo ${ }^{216}$. Isto implicava a destruição das estruturas coloniais e a introdução de uma nova estrutura que ganhou força urbana quando durante a realização do Terceiro Congresso ${ }^{217}$ aconteceu a primeira grande crise de abastecimento nas cidades ${ }^{218}$.

Em consequiência, é acelerada a formação das cooperativas de consumo com fornecimento privilegiado e uma elevada percentagem da população torna-se cooperativista. As cooperativas abrem estabelecimentos ao nível de bairros e aos sócios é atribuída uma caderneta onde se registravam os produtos adquiridos, uns de forma racional e outros em venda livre ${ }^{219}$.

uma política econômica com vista à liquidação do subdesenvolvimento e das condições para a elevação do nível de vida do povo trabalhador (CONSTITUIÇÃO DA REPUBLICA POPULAR DE MOÇAMBIQUE, 1975).

${ }^{215}$ Existiu, com alguma intervenção militar em algumas zonas (sobretudo Tete), um movimento de guerrilha designado de COREMO (Comitê Revolucionário de Moçambique), apoiada pelo Malawi, que era combatida política e militarmente pela Frelimo. Outros grupos de nacionalistas e dissidentes da FRELIMO possuíam diferentes organizações, embora sem representatividade e presença militar. A FRELIMO acusava a COREMO de aliada e braço executivo do exército colonial. A COREMO pretendeu durante o processo de negociação da independência, em 1974/5, apresentar-se como um terceiro interlocutor (MOSCA, 2005).

216 A FRELIMO desafiava uma revolução socialista, sem qualquer fase intermediária. Implicitamente, estava adotada a tese do Partido Comunista da União Soviética que, em nome de Lenin, havia substituído a teoria da necessidade da fase democrático-burguesa para a revolução socialista pela do caminho não-capitalista para o desenvolvimento (BOTTOMORE, 1988).

${ }^{217}$ A realização deste congresso em Fevereiro de 1977 mais não é do que uma forma de consagrar os princípios consagrados na Constituição de 1975. Neste sentido pode dizer-se que o congresso institucionaliza o que já era prática na sociedade moçambicana (CARVALHO, 2008).

${ }^{218}$ Segundo Mosca (1999), na cidade de Maputo os cidadãos faziam longas filas nas lojas e a cidade passou por alguma instabilidade social, os dirigentes da FRELIMO demonstraram preocupação de se encontrar um instrumento julgados capazes de, em menos tempo possível, superar a crise e o atraso do país que deveria passar por uma modernização econômica. Os intelectuais ao serviço do regime consubstanciaram o regime dando um salto rumo à patrulha às lojas e se constatou que para além de déficits efetivos de bens existiram, por parte de alguns comerciantes, ações propositadas de açambarcamento de produtos com o objetivo de criar o caos na cidade nas cidades Moçambicanas. Ao nível da cidade de Maputo, foi criado o GOAM (Gabinete de Organização do Abastecimento de Maputo) para a organização do abastecimento racionado. As quantidades atribuídas a cada pessoa não eram suficientes. A razão era apenas uma: o rendimento não era suficiente para cobrir as necessidades mínimas de sobrevivência. O fluxo de bens das famílias no campo era, na altura do estudo, muito reduzidas. A pobreza na cidade de Maputo começa a ganhar dimensões.

${ }^{219}$ Paralelamente, foi instituído o abastecimento por quotas (racionamento) nas principais cidades, segundo o qual cada família possuía certo volume de bens alimentares básicos, que variavam em função do agregado familiar e segundo as disponibilidades existentes que eram atribuídas pelo Ministério do Comercio Interno (MOSCA, 20005). 
Para realização deste objetivo o Estado confiava principalmente na força do povo e nos recursos econômicos do país, concedendo um apoio total na produção agrícola, promovendo aproveitamento adequado das empresas de produção e procedendo a exploração dos recursos naturais. Para o processo de edificação da base econômica, o Estado procederia às bases para o desenvolvimento, tomando agricultura como potencial para o fornecimento da matéria-prima para as indústrias que dinamizariam a economia, partindo de uma substituição das importações. Porém, a reestruturação do aparelho do Estado ia se dando dentro de reformas importante, com vista a reformular o aparelho do estado colonial. Para tal, a concepção organizacional foi assente no princípio do centralismo democrático, partindo da liderança do partindo-Estado, juntos dos operários e camponeses partiram para o quadro teórico leninista ${ }^{220}$. Discriminatoriamente, a FRELIMO começou agindo, o exemplo mais concreto, foi o comportamento da FRELIMO face à igreja, principalmente a católica, em que limitou as suas atividades da prática dos cultos. Esta igreja possuía missões em muitas partes do país, entretanto, na maioria delas prestavam serviços de saúde, educação, etc. Estas atividades em muitos locais eram as únicas ${ }^{221}$.

Como único partido autorizado em Moçambique a FRELIMO construiu as diretrizes econômicas, aliada internamente aos operários e camponeses ${ }^{222}$. Assim sendo, o Estado passou a defender a redefinição dos objetivos das políticas econômicas herdadas do colonialismo,

\footnotetext{
${ }^{220}$ Aliança sem que os camponeses tivessem a noção de país e de nação, e um operário iniciante e com uma consciência de classe pouco consistente, exceto em uns poucos setores industriais e de serviços (portos e caminhos de ferro, empresas açucareiras e pouco mais) (CASAL, 1996).

${ }^{221}$ Segundo Castel-Branco (1995), para a FRELIMO a discriminação de algumas instituições vem da necessitava de integração dos serviços da educação e saúde nas nacionalizações, que foi tomada no dia 24 de julho de 1975, um mês após a independência. Inicialmente, a FRELIMO era extremamente crítica com as igrejas e especialmente com a católica; Samora Machel, no discurso que proferiu no $1^{\circ}$ Seminário Nacional da Agricultura, realizado em Marrupa em Junho de 1975, quando realizava a viagem do norte para sul, referiu-se que: "Através da igreja, através do islamismo, apoiavam o colonialismo portugueses". Estes e outros discursos demonstram uma frontal crítica à igreja e particularmente acerca do papel da igreja católica na colonização. Estas situações passaram pela discriminação das administrativamente as autoridades gentílicas que passam a ser vistos como inimigo do povo, por compartilhar com sistema colonial, para tal deviam se extinguir. Assim como, a FRELIMO ordenou que as fotografias dos antigos elementos do aparelho ideológico e repressivo português fossem fixadas em placares nos receptivos locais de trabalho. Estes "comprometidos" ${ }^{221}$ não podiam ser membros da FRELIMO, das assembléias do povo, nem desempenhar funções de responsabilidade no Estado e nas empresas estatais (E.E.). De acordo com Casal (1996), a lista de países africanos que, reclamando-se do socialismo, ignoraram, desprezou ou tergiversaram as estruturas tradicionais em nome do desenvolvimento é longa: Mali, o Gana, a Guiné-Conacri, na década dos anos 60-70, Moçambique, Angola.

${ }^{222}$ O Partido FRELIMO se estruturava hierarquicamente como uma pirâmide e no topo se situa seu Secretário Geral, seguido em ordem descendente pela Comissão Política, Comitê Central, Conselhos Provinciais e Distritais, Delegações e Células na base. Dentro dessa estrutura hierárquica, assuntos do interesse e relevantes ao Partido são discutidos à medida que surgem a qualquer nível. Sempre que a decisão é tomada por uma estrutura superior imediatamente acima, ela (decisão) é transmitida ao órgão imediatamente abaixo como diretriz e deve ser cumprida. Esta é a parte do "centralismo". Uma vez que a decisão é tomada e transmitida à estrutura descendente da linha de organização política, então deve ser executada como política do partido ou diretiva (CHAMBOTE, 2012).
} 
rompendo, assim com o passado colonial ${ }^{223}$. Com base numa acumulação concentrada nos sectores produtores de bens de equipamento, sacrificando os sectores de bens alimentares ${ }^{224}$. A concentração da produção tinha de ser em monopólios constituídos por grandes empresas estatais, cuja produção é determinada pelo plano, isto para maximizar volume da produção como objetivo de controlar os padrões de acumulação e a maximização das receitas públicas ${ }^{225}$. Entretanto, as opções políticas e o crescimento econômico foram se desenvolvendo a nível macro.

O sector governamental tinha necessariamente, um grande peso na utilização dos recursos econômicos, o que é revelado pelos déficits do gasto público nacional, ser financiados pelos excedentes das empresas estatais, nas áreas de defesa, segurança, criação de tecnologia e nas áreas sociais. Agricultura foi considerada a base do desenvolvimento e a indústria ligeira o fator dinamizador. A indústria pesada viria a ser definida como o setor determinante para a independência econômica. Agricultura tinha como funções a produção de alimentos para o povo, matérias-primas para a indústria nacional e produtos para a exportação, devendo ser o principal setor gerador de divisas ${ }^{226}$. Agricultura e o comercio interno e a oferta de serviços foi considerada setores prioritários, com o apoio do setor estatal, as cooperativas seriam as bases para a construção do socialismo e considerados "formas superiores de produção". As aldeias comunais seriam a "coluna vertebral" do desenvolvimento do campo ${ }^{227}$.

\footnotetext{
${ }^{223}$ Estas mudanças, teoricamente, seriam realizadas dentro de um equilíbrio econômico estabelecido através de balanços materiais inter setores. Neste modelo econômico socialista se destaca a importância do crescimento econômico ser na base da indústria pesada, como forma de alcançar a independência econômica, possibilitando um crescimento mais rápido em longo prazo, mas com sacrifícios no consumo em curto prazo. Defendia-se que a mudança da estrutura econômica e a introdução da indústria pesada permitem o desenvolvimento e a modernização de outros sectores sem dependência externa, alterando a natureza das relações externas e a inversão dos termos de troca (MOSCA, 2005).

${ }^{224}$ De acordo com Mosca (2005), os casos empíricos demonstram que as taxas de investimento público são geralmente elevadas devido à importância das transformações estruturais no quadro do projeto político e ao desejo de crescimento. Segundo o modelo econômico socialista confirmado em experiências empíricas, a procura não está fundamentalmente determinada pelo consumidor, mas pela capacidade de produção e as prioridades na distribuição de bens e serviços, são atribuídas pelos panificadores considerando os níveis dos preços também planificados. As rupturas de mercado e as opções da oferta standards, bem como os mecanismos do plano, indicam a prioridade das primeiras: o desenvolvimento tecnológico e de alguns sectores (como a defesa, a conquista do espaço, etc.), secundariam os padrões de consumo e a oferta de bens e serviços relacionados com os níveis e qualidade de vida, e com a liberdade dos consumidores.

225 Ibidem.

${ }^{226}$ Ver. FRELIMO. Diretivas Econômicas e Sociais do $3^{\circ}$ Congresso. Maputo, Frelimo. 1977; Relatório do Comitê Central ao $3^{\circ}$ Congresso. Maputo, Frelimo. 1977.

${ }^{227}$ A prática do pagamento de salários baixos era como objetivos de manterem estável a procura agregada de forma a direcionar os recursos para o investimento e evitar a acumulação privada para equalizar a sociedade no quadro da construção da sociedade sem classes.
} 
A gestão do sector externo obedece aos mesmos paradigmas do período anterior, onde a planificação determinava em médio prazo as relações comerciais estabelecidas. Foram celebrados acordos governamentais de cooperação, onde as empresas estatais de comércio externo funcionavam como organizações executoras obedecendo às quantidades a exportar e importar num sistema de câmbios fixos a preços administrativamente ${ }^{228}$. O mercado internacional é dominado pelas relações capitalistas; o modelo, embora procurando algum isolamento resultante da priorização das relações entre países socialistas, o fato é que não era possível o isolamento absoluto. As relações entre os sistemas capitalistas e socialistas são realizadas segundo as leis do mercado internacional controlado pelos trusts que introduzem situações monopolistas (ou oligopolistas), pela influência das respectivas políticas internas e por organizações internacionais. O comércio internacional foi freqüentemente utilizado como instrumento político ${ }^{229}$.

No biênio 1978/79 um instrumento legal foi criado para orientação econômica, o Plano Econômico Central (PEC) ${ }^{230}$, com objetivo de garantir as relações externas, através de acordos de cooperação, com os países socialistas, procurando abriram linhas de crédito a taxas de juro baixo e com boas condições de pagamento. Esta arrecadação de apoios dos países socialistas procurou obter acessos a recurso financeiro para o desenvolvimento de grandes projetos, concentrados, sobretudo na agricultura, dependente da utilização da mão de obra especializada estrangeira $^{231}$. As empresas de comercio externo concretizavam as decisões políticas através de

\footnotetext{
${ }^{228}$ As relações comerciais entre os países socialistas são preferidas. No âmbito do COMECON, existiram programas de desenvolvimento de mega - projetos no quadro de uma divisão e especialização do trabalho entre países com benefícios assimétricos de acordo com as relações de poder político, econômico e militar.

${ }^{229} \mathrm{O}$ caso dos produtos alimentares e as restrições para a comercialização e transferência de tecnologias são sobejamente conhecidos (CHAMBOTE, 2012).

${ }^{230}$ Segundo Mosca (2005), o PEC que se designava Plano Econômico Central, passou a ter a designação de PES (Plano Econômico e Social).

${ }^{231}$ Por esta razão, a opção de transformar a FRELIMO num 'partido de vanguarda' marxista-leninista tinha também um objetivo externo: convencer os países socialistas sobre as opções econômicas e sociais e do modelo de sociedade. A tentativa de adesão á organização econômica COMECON (Council for Mutual Economic Assistance), durou anos, sendo finalmente rejeitada nos princípios da década dos anos 1980. Porém, embora durante o tempo que Moçambique fosse membro do COMECON, este estatuto não dava acesso a linhas de crédito, financiamento e cooperação em condições mais vantajosas (comparativamente ás condições de membros permanentes). Simultaneamente a Moçambique era ainda candidatos Cuba e Vietname. Para alem dos fatores econômicos, existia um debate teórico e político sobre as revoluções africanas e os movimentos de libertação nacional, que muitos recusavam o reconhecimento como partido marxistas ou que as transformações que se operaram eram de natureza socialista. A questão teórica de fundo era aceitar ou não a possibilidade de construção do socialismo a partir do nível de desenvolvimento econômico (ou das forças produtivas na linguagem marxista) e se existiriam, nas condições africanas, as transformações das relações de produção que caracterizam, teoricamente, os processos e as revoluções socialistas. Esta pode constituir a justificativa pela qual a FRELIMO repetidamente fazia referência ao socialismo
} 
acordos comerciais que incluíam o fornecimento de equipamentos e de técnicos; os acordos governamentais davam preferência para que empresas dos países socialistas explorassem recursos naturais (como por exemplo, o carvão de Tete), obtivessem licenças de pesca e exportassem produtos agrícolas resultantes dos projetos agrícolas em que estivessem envolvidos.

\subsection{Gestão das Empresas Estatais}

Este tópico descreve como era à gestão planejada de algumas empresas estatais, uma área prioritária para o desenvolvimento econômico do socialismo moçambicano. Um processo que teve a sua alavanca nos finais dos anos 1970, como o instrumento legal de orientação econômica, o Plano Econômico Central (PEC), que procurou reestruturar e programar a atividade do Estado, elaborando dentro do plano, o controle da direção e gestão macroeconômica em grande medida sob a realização do Estado e das Empresas Estatais. O plano para além de definir os diferentes componentes associadas diretamente com o setor produtivo, estabelecia diretivas para o conjunto da economia, designadamente sobre o crescimento econômico, o consumo e o investimento, o setor e as contas públicas traçavam limites da oferta monetária e objetivo de controlo da inflação definia objetivos da cooperação e das relações externas, etc. ${ }^{232} \mathrm{O}$ Conselho Nacional do Plano (CNP) possuía técnicos de vários países socialistas (sobretudo da URSS e da RDA) e desempenhava uma função de coordenação dos ministérios econômicos. No aparelho de Estado nível central e provincial, formaram-se órgãos de planificação diretamente subordinados aos respectivos responsáveis ${ }^{233}$.

Entretanto, o PEC constituía o instrumento de poder e de acesso aos recursos; onde nos primeiros anos, apenas eram planificados os setores "socialistas" de produção (estatal e as cooperativas - pilotos $)^{234}$. Neste período dos finais dos anos 1970, existia um grande entusiasmo

cientifico, rejeitando os socialismos africanos e outros (CASTEL-BRANCO, 2003).

${ }^{232}$ Ver. Fernando Jorge Cardoso. Gestão e Desenvolvimento. Moçambique no Contexto da áfrica Sub-sahariana. Lisboa, Fim de Século Edições. 1993; Economias locais e empresas estatais agrárias em Moçambique (mercados oficiais e paralelos na zona da Maragra em 1983-85). Em Estudos de Desenvolvimento. África em Transição. UTL, ISEG, CEA. 2000.

${ }^{233}$ Ver. CASTEL-BRANCO. Sobre a "eficácia" e "eficiência" social e financeira da política econômica e as prioridades econômicas e sociais.2014.

${ }^{234}$ Estas medidas foram garantidas na constituição, pelo artigo 10, onde defendia que o sector econômico do Estado era o elemento impulsionador da economia nacional. Para tal, Assembléia Popular, como órgão legislativo supremo, 
na elaboração dos planos das empresas bem como cada setor. Quadros e técnicos, nacionais e estrangeiros, apresentavam propostas. Nas empresas, as metas de produção e as condições materiais, financeiras e de força de trabalho eram calculadas com base em parâmetros e em normas técnicas, muitas vezes sugeridas pelos ministérios com pouca relação com as condições de produção. O plano previa as metas de produção, os insumos e a força de trabalho necessário, os recursos financeiros e os investimentos, as necessidades de importação e definia a distribuição da produção. A economia começava a ser dirigido centralmente, o mercado a ser controlado e os equilíbrios macroeconômicos eram previstos com base nos balanços materiais inter-setores. $\mathrm{O}$ objetivo era maximização da produção ${ }^{235}$.

As metas eram geralmente ambiciosas e muitas vezes correspondiam mais ás pressões dos responsáveis e funcionários dos ministérios que às condições reais das empresas. Praticamente não existiam restrições financeiras, tanto para investimento como para as despesas correntes $^{236}$. As empresas funcionavam com contas bancarias abertas após a aprovação dos planos pela comissão nacional do plano (CNP) e operavam com gestão orçamental. As receitas eram depositadas em outras contas e os gestores na podiam geri-las. Os técnicos estrangeiros era pagos diretamente no país de origem através dos fundos das linhas de créditos e dos valores em moeda nacional era-lhes assegurados ou pelas empresas ou pelas embaixadas. Os investimentos em equipamento eram pago diretamente às empresas importadoras pela banca por ordem do respectivo ministério ou acumulavam-se dividas em consequiência de os fluxos de bens não terem contrapartidas financeiras ${ }^{237}$.

que tinha de planificar a ação dos membros de modo a exercer uma função de confiança no Estado. Os membros da Assembléia Popular tinham uma função basicamente de legislar a política interna e externa, também, aprovavam os relatórios de execução dos orçamentos e planos econômicos nacionais, entre outras coisas; definiam as bases da política dos impostos, ratificavam e denunciavam acordos e tratados internacionais, assim como, aprovavam relatórios das atividades do Governo. Entre outras atividades; retificava os atos legislativos da Comissão Permanente da Assembléia Popular; concedia amnistias; sancionava a suspensão das garantias constitucionais quando declarados o estado de sítio ou de emergência; autorizava o Presidente da República Popular de Moçambique a deslocar-se ao estrangeiro. Porém, Assembléia popular como um órgão convocado e dirigido pelo Presidente da República elegeu os Grupos Dinamizadores, com elemento crucias na responsabilidade da gestão político-administrativa nas áreas urbanas e rurais e, também, nas empresas.

235 Ver. CASTEL-BRANCO, Nuno. Indústria e industrialização em Moçambique: a análise da situação atual e linhas estratégias de desenvolvimento. 2003.

${ }^{236}$ Segundo Cardoso (1993) é nítida a fraca prioridade concebida pelos gestores aos aspetos de ordem financeiros e cantábiles na gestão corrente, o que é consistente com o sistema então existente de concessão de crédito a descoberto e de controlo dos planos a partir do cumprimento das metas de produção quantitativos. Com efeito, a preocupação com os problemas decorrentes de crédito bancários vem no fim da lista nas respostas à pergunta 13, e na maioria das empresas refere não ter a contabilidade organizada ou em dia.

237 As questões financeiras eram tratadas entre bancos. Assim sendo, em Moçambique a empresa receptora do equipamento ficava a dever à distribuidora, esta à importadora e finalmente ao Banco de Moçambique. Gerava-se 
O funcionamento das empresas e as relações empresariais, na maior dos casos, entre as empresas apenas existiam relações operacionais ${ }^{238}$ com a estrutura do Estado aos diferentes níveis não estavam clarificadas. Ao diretor eram pedidas responsabilidades pelo cumprimento dos planos de produção, embora deles não dependesse a decisão final sobre a definição das metas, sobre a afetação de recursos a cerca do momento de chegada dos insumos, das matériasprimas e dos equipamentos ${ }^{239}$. Porém, do gestor da empresa estatal não dependia a decisão de que técnicos contratar; chegavam às empresas equipas de técnicos cujo perfil profissional não tinha conhecimento. Afetação dos técnicos dentro das empresas era realizada pelo chefe da equipe estrangeira, que em muitas ocasiões tinha as funções de coordenação e de ligação com a direção da empresa para a compra de equipamento nas empresas comerciais externas ${ }^{240}$. Assim sendo, os diretores sabiam que a única variável controlada pelos órgãos de tutela era o volume de produção e, quando muito, os rendimentos produtivos (por exemplo, a produção por hectare na agricultura, do qual se pretendia inferir sobre a eficiência e a boa organização das empresas) $)^{241}$.

As preocupações acerca das condições de trabalho e das relações entre os responsáveis e

uma cadeia de dívida incobrável. Nós casos em que se realizava o pagamento, os procedimentos eram geralmente os seguintes: o orçamento público pagava à empresa distribuidora em nome da empresa receptora do equipamento; suponhamos que, conseqüentemente, a empresa distribuidora pagaria à importadora e esta ao Banco de Moçambique (MOSCA 2005).

${ }^{238}$ Muitos destes conflitos eram superados quando o diretor da empresa ou o presidente do Conselho de Administração (CA) era um prestigiado membro da FRELIMO e possuía capacidade técnica, era muito importante na confiança para o partido.

${ }^{239}$ Os PEC eram aprovados anualmente na Assembléia da República sob forma de lei, podendo o não cumprimento ser punível. Por um lado, as lacunas legais sobre aspectos e, por outro lado, as dificuldades de atribuições de responsabilidades individuais não permitiram a penalização jurídica pelo não cumprimento das metas de produção (MOSCA, 2005).

${ }^{240}$ Muitas decisões eram tomadas em reuniões dessas equipes com o respectivo chefe; a empresa não possuía capacidade para a discussão técnica. Segundo Mosca (2005), o diretor da empresa funcionava como um capataz: não decidia sobre os investimentos nem sobre os financiamentos de exploração. As equipes técnicas chegavam e regressavam ao fim da comissão de serviços sem que, muitas vezes, os responsáveis das empresas soubessem algo acerca da formação dos mesmos; em muitos casos as decisões técnicas eram alheias á impunham as metas de cima para baixo; ao nível das empresas, a tarefa era garantir a operacionalidade, a organização e a disciplina. Os gestores tinham possibilidades limitadas de iniciativa e inovação. O incentivo principal era o cumprimento da meta de produção, indicador principal utilizado nas reuniões de balanço e de prestação de contas: o grau de cumprimento refletiu a capacidade do gestor de alcançar rendimentos elevados de produtividade. Em muitas circunstâncias, chegavam maquinas às empresas com características novas, sem que houvesse a preparação de operadores e da assistência (mecânicos, eletricistas, etc.), as peças sobressalentes chegavam muitas vezes tarde. E fácil compreender quais as razões do não cumprimento das metas é que estas eram definidas acima das capacidades reais das empresas o que era acompanhado por atrasos na logística (MOSCA, 2005).

${ }^{241}$ Perante a perspectiva de prestação de contas e face à quase inexistência de restrições financeiras, as empresas tudo faziam para cumprir as metas de produção: para efeito, não havia limites, na utilização de fertilizantes azotados para estimular a produção ou a aplicação de excessivas doses de produtos químicos, independentemente dos custos e das conseqüências sobre os solos e sobre equilíbrios biológicos no combate às pragas. Por vezes a utilização da maquina era excessiva (MOSCA, 2005). 
os trabalhadores das empresas não sofreram alterações fundamentais com os existentes no período colonial ${ }^{242}$. A segurança social e no trabalho, assistência social e os apoios aos trabalhadores eram praticamente inexistentes ${ }^{243}$. No comando da empresa os métodos de direção e gestão estavam muito influenciados por responsáveis desmobilizados do exercito da FRELIMO que introduziram formas militares de relacionamento ${ }^{244}$. Um característico assumido por muito dos novos quadros nas direções, foi mais autonomia de gestão o que piorou as relações de muitas empresas com as populações e com os órgãos locais do pode, sobretudo para aquelas que dependiam diretamente dos órgãos centrais (ministérios, Comissão Nacional de Plano e Conselho de Ministros) $)^{245}$.

Portanto, as relações das empresas para com a população eram igualmente pouco positivas. Os camponeses mantiveram-se sem acesso às terras de que tinham sido $\operatorname{expropriados}^{246}$. Porem, se manteve muita coerção em conseqüência da persistência do sistema de monocultura das grandes plantações e das machambas dos colonos; o salário e o poder de compra; outras oportunidades de emprego e de obtenção de rendimento tinham diminuído ${ }^{247}$.

\footnotetext{
${ }^{242}$ As expulsões sem processo disciplinares eram freqüentes. Foi introduzida a lei que garante a indisciplina e punidas com base na utilização método coercivos, desajustada e desproporcionada da realidade social. Porem, o exemplo a lei da chicotada aprovada em 1981. Introduziu a punição corporal como pena adicional para uma grande variedade de ofensas. Ainda, a lei não tinha sequer sido aprovada em plenário: tinha corrido à pressa pela Comissão Permanente da Assembléia Popular, a 1 de Abril, precisamente alguns dias depois de a Assembléia Popular ter terminado uma sessão. Portanto, a Constituição bania a tortura. A justificação dada para a lei da chicotada foi à preocupação popular sobre o aumento da criminalidade (FAUVET e MOSSE, 2004).

${ }^{243}$ Os compounds não possuíam condições de vida (eram as mesmas das anteriores, mas com as infra-estruturas determinadas e com piores serviços); os tratamentos químicos eram aplicados sem equipamento de proteção (Uniforme, capacetes, etc.) (MOSCA, 2005).

${ }^{244} \mathrm{O}$ diretor centralizava o poder, o que reforçou as alianças entre a burocracia do Estado e do partido e marginalizou os trabalhadores dos processos de decisão e de discussão nas empresas. Deste modo, a participação inicial dos trabalhadores através dos GD e dos CP, algo anárquica, foi transformada na tomada do poder pelas elites emergentes e o abandono dos métodos democráticos de participação dos trabalhadores e da sociedade.

${ }^{245}$ Mosca (1999) refere que, os diretores não tinham que prestar contas, mas, simultaneamente, as empresas dependiam de muitos aspetos locais, como por exemplo, da força de trabalho. Os responsáveis e técnicos das empresas possuíam viatura e os representantes do Estado nos distritos geralmente não tinham qualquer meio de transporte. Os salários destes eram na maior parte dos casos inferiores. Estes e outros aspetos provocaram fricção que contribuiu para o não cumprimento dos planos. As acessibilidades dos diretores das empresas às instituições e responsáveis de níveis nacionais eram mais fáceis e fluidas que a dos administradores distritais e diretores provinciais do Estado. Os primeiro possuíam geralmente níveis de formação mais elevada. Os segundo eram em muitos casos mais próximos das burocracias do Partido e dos militantes relacionados com o período da guerra de libertação e os segundos pertenciam às novas elites surgidas após a independência. Os primeiros eram os políticos e os segundo os tecnocratas, onde muitos eram não negros.

${ }^{246} \mathrm{O}$ recrutamento para o trabalho possuía momentos que recordavam os métodos coloniais associado à posse e prioridade de terra, aos métodos de recrutamento de mão de obra no processo de implantação das grandes plantações, da emigração para os países vizinhos e no contexto da socialização do campo (O' LAUGNLIN, 2002).

${ }^{247}$ Surgem novos abusos de poder, como por exemplo, a não existência de liberdade de circulação de bens e de pessoas, mesmo nas zonas não abrangidas pela guerra, assim como, os abusos praticados nos pedágios das estradas,
} 
Não obstante, em termos econômicos, as relações entre as empresas estatais e os camponeses foram-se alterando. Numa primeira fase a organização econômica do "socialismo" moçambicano concentrava a acumulação no Estado, as empresas estatais possuíam a função de limitar os mecanismos de reprodução das economias privadas e de pequenas escalas ${ }^{248}$. Porém, os produtores de pequena escala e o setor privado não eram incluídos na afetação de recurso ${ }^{249}$. O governo controlava o mercado, principalmente quanto à capacidade de troca dos excedentes agrícolas, dentro da lógica do dirigismo estatal (onde os preços eram controlados pelo Estado) ${ }^{250}$.

\subsection{Características das empresas Estatais}

Este tópico procura caracterizar o processo de produção nas empresas estatais organizadas no Plano Econômico Central (PEC), que nos finais dos anos 1970 procurou reestruturar e programar a atividade das empresas do Estado. Nesta perspectiva da construção do socialismo faz uma abordagem partindo de algumas empresas industriais e agrícolas de grande dimensão e consideradas importantes. Entretanto, algumas empresas privadas industriais e agrícolas de grande dimensão e consideradas importantes (sobretudo pelo tipo de bens produzidos) foram posteriormente, no inicio dos anos 1980, incluídas na planificação combinada com as empresas

onde a circulação de pessoas era controlada através dos Grupos Dinamizadores que passavam as guias de marcha, um instrumento inspirado do período da luta de libertação nacional, utilizado para controlar o movimento da população nas zonas de guerra e não faziam esquecer as formas de controlo coloniais. Por outro lado, os abusos de poder são demonstrados nas mobilizações muitas das vezes não voluntárias para as aldeias comunais, como acontece o vale do Limpopo (em Choókwè), após as cheias de 1977, a FRELIMO formou uma "comissão de alto nível para realocar a população afetada. A comissão concluiu que a população deveria ser reinstalada nas terras altas em aldeias comunais; se a população recusasse a aderir, poderia utilizar "medidas administrativas (ou seja, força)" (HEREMELE, 1986). Entretanto, nas zonas de guerra, as populações foram, em muitas circunstâncias, forçadas a abandonar os seus locais de residência e a incorporarem-se nas aldeias. Segundo Geffray e Pedersen (1985), em Março de 1984, com a aproximação da situação de guerra, a orientação do exército a esta fração majoritária do campesinato, que até ai tinha permanecido fora das aldeias, foi forçar a entrar na mesma. Foi feito um ultimato às populações a data de 15 de Março. A milícia encarregou-se da opção de uma maneira por vezes radical (palhotas incendiadas).

${ }^{248}$ Cardoso (2000) defende que, na fase das reformas econômicas (a partir de 1983/86), “o setor estatal e os circuitos planificados da economia alimentavam a prática do mercado (paralelo), através da canalização de recursos induzida pelos elevados diferenciais de preços praticados. Nestas circunstâncias, os gastos econômicos atuante no mercado paralelo apropriavam-se do essencial da acumulação gerada na zona" (referindo-se ao distrito da Manhiça, onde se localizava a empresa estatal de produção de açúcar da Maragra).

249 Através do plano, controlava-se e afetava-se grande parte dos recursos, como por exemplo, dinheiro e credito equipamento, bens e serviços importados (matérias-primas, combustíveis, etc.).

${ }^{250}$ Segundo Abrahamsson e Nilsson (1994) no ano de 1986 (depois das primeiras liberalizações em 1983), o sistema oficial de preço fixo compreendia 46 diferentes tipos de mercadorias. O seu valor total de vendas respondia por cerca de 70 por cento do PNB. 
estatais $^{251}$. A inclusão das empresas privadas no PEC teve como necessidade de acesso a alguns recursos, sobretudo os bens importando ${ }^{252}$. O plano cobria assim apenas uma parte da realidade, portanto, muitos aspetos dos setores de pequena escala e dos privados e uma grande parte das cooperativas não estavam inclusos. Essa observação se deve, por um lado, a capacidade dos produtores de pequena escala resistir às políticas econômicas que dificultavam os seus mecanismos de funcionamento e, por outro, refletem as dinâmicas destas economias de se integrarem, de se adaptarem e de extraírem vantagens no quadro das lógicas de sobrevivência ${ }^{253}$.

Tem importância na estrutura do setor produtivo a formação da Empresa Estatal de Mecanização Agrícola (MECANAGRO). Esta empresa concentrou todo o equipamento agrícola então pertencente às empresas estatais e aos parques de máquinas das direções provinciais de agricultura (DPA), exercendo as funções de prestações de serviços (aluguer e assistências técnica), colocação de encomendas de peças sobressalentes, gestão dos parques de máquinas espalhados por todo o país, etc. A dimensão e complexidade da empresa conflitavam com a capacidade e meios de gestão, com a qualidade do corpo técnico, etc., a empresa geria, por exemplo, as máquinas que pertenciam ás empresas agrícolas estatais e que só trabalhavam nessa mesma empresa e possuía toda a assistência, oficial e pessoal (operadores, mecânicos, etc.) dessa empresa. Isto é, enxertava-se uma empresa dentro de outras com meios já existentes, introduzindo, naturalmente, ineficiências e desorganização. As empresas de produção agrícola viram-se desprovidas de um dos meios de produção mais importantes e cuja utilização influenciava a situação econômica e financeira ${ }^{254}$.

Os ganhos operados com a formação da MECANAGRO seriam resultantes da economia de escala, da especialização e do controlo do patrimônio. Objetivo político da formação desta

\footnotetext{
${ }^{251}$ De acordo com Mosca (2005) a planificação do setor privado não incluía um conjunto de aspectos contemplados para o setor estatal, como por exemplo, recursos financeiros, assistência técnica e investimentos públicos. Na indústria eram ainda previstas as necessidades de metas.

${ }^{252}$ Relativamente aos produtores de pequena escala, o plano previa a produção e a venda da produção, sobretudo, no setor agrícola, o comércio interno e a oferta de serviços, com base em dados históricos e o "abastecimento do povo", que estimava o volume de bens manufaturados a serem vendidos pela rede comercial rural: o objetivo principal era a troca com os excedentes agrícolas (MOSCA, 2005).

${ }^{253} \mathrm{O}$ caso da Manhiça é semelhante ao surgimento das economias informais, sobretudo nas cidades. Mosca (1993) em relação ao Chókwè refletem estrategicamente semelhanças no seio das famílias, designadamente; a concentração das atividades em áreas da economia não planificadas pelo Estado, beneficiando-se do mercado paralelo e da redução do risco policial. Assim como, quanto às diversidades das atividades econômicas e uma redefinição da divisão social do trabalho no seio das famílias (por exemplo, com um contributo importante da mulher). Por outra, o aproveitamento das (dês) funcionalidades entre o mercado e o plano e das debilidades do setor estatal em benefícios próprios, como por exemplo, as diferenças de preços dos mercados paralelos e "oficial" e a obtenção de vantagens de um membro da família ou amigo, trabalhar numa empresa estatal ou na administração pública.

${ }^{254}$ Ibidem.
} 
empresa era a prestação de serviços a todos os agentes econômicos, especialmente ás cooperativo, de forma a alterar a concentração do equipamento só no setor estatal e abrir a acessibilidade dos diferentes agentes econômicos à mecanização. A MECANAGRO deveria transforma-se num instrumento importante da mecanização agrícola, um dos objetivos da socialização do campo. Na realidade, as acessibilidades dependiam ainda de recursos dos agricultores e das cooperativas, da dimensão de terra para justificar a rentabilidade de sistemas de produção que facilitassem a mecanização. Sendo escassas estas possibilidades, os efeitos da MECANAGRO foram muito limitados ${ }^{255}$.

Se nas empresas agrícolas a função maximização era o volume de produção, a MECANAGRO tinha como objetivo trabalhar o máximo de área, independentemente da rentabilidade econômico e financeiro ${ }^{256}$. A propriedade da agricultura foi real ${ }^{257}$. Os grandes projetos com alguns países socialistas (como exemplo o projeto de 400 mil hectares principalmente na província de Cabo Delgado com a cooperação romena, os 120 mil hectares principalmente para a produção alimentar com a Alemanha Democrático, ou a construção de 300 mil hectares de regadio no vale do Limpopo), pretendiam a socialização e modernização acelerada do meio rural através de empresas estatais ${ }^{258}$.

Este projeto enquadrava-se nos acordos intergovernamentais de cooperação econômica e técnicos de logo prazo assumidos ao mais alto nível, preparados e fiscalizados por comissões de especialistas das partes contratantes. Os equipamentos, técnicos e outros fatores eram fornecidos por empresas dos países assinantes no quadro de linha de crédito e geralmente faziam parte de um conjunto de acordos setoriais que previam a cooperação em vários domínios: econômicos, sociais e culturais ${ }^{259}$.

\footnotetext{
${ }^{255}$ Ver. Pitcher (2003).

${ }^{256}$ Wuyts (1979) no trabalho On the Questiono $f$ Mechanization of Mechanization of Mozambican Agriculture today:some theoretical Comments, refere, entre outros aspetos, que objetivo da mecanização da agricultura pretendia maximizar a produção de excedentes de alimentos. Mas se verificaram pouco raciocínio no uso das maquinas, como por exemplo, o deslocamento de tratores a quilômetros de distância para trabalhar pequenas áreas, gastando-se, em algumas ocasiões, mais tempo e combustível na deslocação que na preparação da terra.

${ }^{257} \mathrm{O}$ volume de investimentos públicos e externos, a propriedade na afetação de recursos da cooperação, a importância dada na colocação de quadros ao setor, a distribuição do crédito, etc., indicavam uma clara relevância da agricultura, isto é, do setor estatal agrário (PENVENE, 1985).

258 Procurava-se aplicar o conceito do desenvolvimento rural mais ortodoxo aplicado nos países socialistas da Europa: modernização com significado de equipamento, produtos químicos, infra-estruturas moderna, especialização produtiva, integração vertical nas respectivas fileiras produtivas, grandes empresas, direção centralizada, obediência ao plano, rigidez diretiva e de gestão, politizada da democracia, entre outros aspetos já mencionados (PITCHER, 2003.).

${ }^{259}$ De acordo com Oppenheimer (2003) muito destes projetos cessaram de vigência com a crise dos países socialista.
} 
No meio rural o Estado além, de rede criar Lojas do povo nas cantinas abandonadas e transformadas ${ }^{260}$. Transformação o Instituto dos Cereais de Moçambique na Empresa Estatal de Comercialização Agrícola (AGRICOM). As Lojas do Povo procuravam gerir as centenas de pequenos estabelecimentos espalhados por todo o país de forma centralizada, o que se revelou impraticável ${ }^{261}$. A AGRICOM ficou tutelada pela Direção Nacional de Economia e Comercialização Agrária (DINECA) que tinha como objetivo, realizar a comercialização (aquisição dos excedentes aos camponeses, armazenagem e transporte entre as zonas excedentárias e deficitária, sobretudo do campo para cidade e do norte para o sul). Também, deveria praticar os preços estabelecidos pelo Estado ${ }^{262}$. Assim como exemplo, a AGRICOM e as administrações locais tinham como função controlar administrativamente os preços oficiais, isto porque o volume comercializado através do circuito da AGRICOM ou de outras empresas e agências públicas eram insuficientes para influenciar os preços através dos mecanismos de mercado $^{263}$. AGRICOM aplicou políticas de subsidiado pelo Estado de importar e exportar produtos alimentares sob tutela da DINECA (principalmente cereais, feijão e amendoim), com objetivo de garantir o abastecimento urbano e estabilizar os preços $^{264}$.

A comercialização agrícola tinha assim, antes e depois da independência, os mesmo objetivos, embora com algumas matizações: de comum, havia o objetivo de manter o custo de

Antes da crise, a partir de meados dos anos 1980 já tinha afetado "mortalmente" a continuidade dos programas. No caso da cooperação com a RDA, estes sofreram alterações fundamentais ou deixaram de existir com a integração das duas Alemanhas.

${ }^{260} \mathrm{O}$ destino de muitos comerciantes rurais foi à saída do país ou a abertura de novos negócios nos centros urbanos. Pouco se mantiveram no meio rural; esta foi à primeira ruptura da rede comercial rural. Posteriormente, a rede comercial foi um dos alvos da Renamo; Leite (1999), afirma que "1982/83 cerca de 5000 retalhistas asseguravam com sucesso a comercialização agrícola. Os efeitos da guerra nas zonas rurais levarão à distribuição desta rede retalhistas, estimada em finais da década de 1980, em menos de 2000 unidades". Deste modo, grande parte de rede comercial rural foram destruídas duas vezes em menos de dez anos.

${ }^{261}$ De acordo com Mosca (2005), por razões agroclimáticas, a produção dos principais produtos consumidos nas cidades (milho, amendoim, feijão, etc.), era principalmente realizada no Centro e Norte do país. Além das razões naturais (clima, solos, etc.), recorda-se que a política econômica colonial configurou uma divisão social do trabalho do campesinato conseqüência de distintas formas e modelos de colonização.

${ }^{262}$ Um estudo de Mauren Mackintosh (1983) verifica, apara o caso da região da Alta Zambézia, nos últimos anos do período colonial, que "os comerciantes combinaram manter baixos os preços pagos aos produtores e redistribuíram entre si áreas exclusivas de comercialização".

${ }^{263}$ No período colonial e durante os primeiro anos depois da independência os preços praticados ao consumidor no Sul eram inferiores aos preços pagos aos produtos no Norte. Os subsídios cobriam as despesas de transporte e os diferenciais dos preços.

${ }^{264}$ Nas ações de comercialização, posteriormente, com a ruptura de rede comercial rural, AGRICOM vendia bens manufaturados. Considerados estes objetivos estratégicos, a DINECA e a AGRICOM sempre foi beneficiada na afetação de recursos, como por exemplo, em meios de transporte; existiam projetos de cooperação de longa duração e com importantes recursos que suportavam a AGRICOM, como por exemplo, o MONAP (Mozambican Nordic Assistance Program) (MOSCA, 2005). 
vida nas cidades para permitir a prática de baixos salários e evitar crise de abastecimento ${ }^{265}$ com conseqüência social e de estabilidade; a diferença fundamental era a de que durante o período colonial a comercialização era um elemento importante da integração do campesinato no mercado e após a independência não se pretendia que existissem processos de acumulação privada, mesmo ao nível das famílias pobres como são a quase totalidade dos camponeses moçambicanos $^{266}$. Os preços ao longo das diferentes fases da fileira dos produtos foram estabelecidos de forma a estimular a atividade comercial ${ }^{267}$. "O fracasso estatal no que respeitam a centraliza os excedentes alimentares na sua própria empresa atacadista (a AGRICOM), foi em parte resultante da estrutura oficial de preços". Surgiram comerciantes que eram simultaneamente atacadistas, retalhistas (com várias lojas em diferentes locais do distrito e não só), moageiros e agricultores, dando origem a um processo de acumulação privada e de diferenciação social que muitas vezes utilizavam os canais públicos de comercialização ${ }^{268}$. Por outro lado, as pequenas margens de comercialização dos bens manufaturados dificultavam a rentabilidade dos pequenos comerciantes e facilitavam os que possuíam escala que garantisse a rentabilidade da atividade, agravado pelo fator de os comerciantes não praticarem os preços oficiais: os métodos administrativos e policiais para estes casos são sempre ineficazes. Havia ainda uma falta de coordenação entre os órgãos estatais no sentido de restringir a liberdade de ação dos comerciantes e de reduzir os preços especulativos ${ }^{269}$.

\footnotetext{
${ }^{265}$ Estes abastecimentos eram realizados preferentemente através das cooperativas de consumo e posteriormente também por intermédio de lojas privadas. Conseqüentemente as famílias tinham encontrado outras fontes de abastecimento: o envio de alimentos das famílias que permaneciam no meio rural. Pós no meio rural nos primeiros anos após a independência, a situação de crise alimentar não atingiu o estado grave. Assim, o comercio informal teve a sua emergência como alternativa de abastecimento. O envio das remessas estava, no entanto, sujeito à 'físcalização' nos postos de controlo nas estradas realizados pelas milícias, que freqüentemente não permitiam a circulação dos produtos. Cumpriam ordens das autoridades estatais locais, ou, por iniciativa individual e de grupo, retiravam os bens dos passageiros para abastecimento próprio. É conhecido que existiram limitações e ordens que proibiam a saída de determinados bens distritos e das províncias (MOSACA, 2005).

${ }^{266}$ A comercialização privada é assim vista por Mackintosh (1983) como sendo, o primeiro setor onde a FRELIMO permitiu, de forma planificada, a acumulação privada. No meio rural, em conseqüência do insucesso da empresas Loja do Povo e da incapacidade da AGRICOM cobrir todo o país e, por outro lado, a necessidade de abastecer os centros urbanos, foi 'tolerada' a atividade comercial privada. Os comerciantes emergiram e surgiram também os vendedores a groso a nível distrital (também eles retalhistas), que tinham como função adquire nas fabricas e nas capitais provinciais as quotas do 'abastecimento do povo' atribuído pelo plano dos numero da população afetada fornecida pela província. Assim, a quantidade a afetar tinha como base a população e também o volume esperado de excedentes agrícolas a serem vendidos pelos camponeses.

${ }^{267}$ Ver. Mackitosh (1983).

${ }^{268}$ Cerca de 80 por cento, segundo as nossas estimativas, passou num ou noutro ponto do circuito comercial pelas mãos do Estado (MACKINTOSH, 1983).

${ }^{269}$ Segundo Mackintosh (1983), o comercio não pode ser apenas visto como um setor que compra e vende, mas como um setor por onde circulam e se distribuem recursos e através do qual se realiza a acumulação; nesse sentido,
} 
A estatização da economia provocou uma forte concentração da propriedade que se manifestou na integração de muitas empresas de pequena e média em grandes Empresas Estatais $^{270}$. Nos transportes aconteceu, por exemplo, o caso já referenciado da formação de três empresas de transporte de passageiros (ROMOS, ROMON e ROMC); com as nacionalizações restaram apenas três bancos (dois estatais e um privado); nos seguros todas as empresas foram nacionalizadas e foi formada a EMOSE (Empresas Moçambicana de Seguros); na indústria criaram-se unidades de direção (UD) ${ }^{271}$, que dirigiam as empresas retirando às respectivas direções muitas das funções de gestões; no comércio externo criaram-se empresas especializadas por tipo de bens ${ }^{272}$. Isto é, a economia “moderna" foi estruturada em monopólios, alguns dos quais tinha como competência controlar algumas pequenas atividades privadas do mesmo ramo de atividades, funcionando simultaneamente com funções empresariais e de Estado.

No campo as empresas estatais tinham ainda funções nas suas "áreas de influência", o que significa que também deveriam prestar serviços aos outros setores sociais de produção cooperativas, privados e produtores de pequena escala (como por exemplo, vendas de insumos, aluguer de máquinas, comercialização dos excedentes, assistência técnica, etc.). No entanto, considerando os limitados recursos e a gestão ineficaz de grande parte das E.E., poucas desenvolveram estas funções ${ }^{273}$. As empresas que se localizavam em zonas com guerra civil entre a RENAMO e a FRELIMO iniciado em 1976, viram dificuldades cada vez mais nas suas atividades. Os custos aumentaram, o funcionamento operacional era interrompido com ataques, o transporte de insumos da produção começou a ser realizado por colunas com proteção militar, a

\footnotetext{
é fundamental a estruturação do setor de forma a permitir que a acumulação privada fosse substituída por qualquer que permitisse o investimento social, como por exemplo, as cooperativas.

${ }^{270}$ Como por exemplo, no setor do chá, nos colonatos, etc.

${ }^{271}$ Estas UD tinham como origem os gabinetes de apoio, do âmbito do Ministério da Indústria; possuíam, de forma especializada (por ramo de atividade), as mesmas funções do aparelho de Estado de direção econômica e procuravam uma maior eficácia. O Mistério da Agricultura também formou as UD (quando o ministro da Indústria que as tinha criado neste setor foi nomeado ministro da Agricultura); como resultado, existiu uma compartimentarão de cima para baixo e burocrático a atividade agrária, que na maior parte dos casos, no terreno, integrava atividades agrícolas, pecuária, florestais, etc., em sistemas de produção coerentes e com importantes sinergias. Uma mesma empresa poderia estar dependente em empresas especializadas, as com a organização da burocracia da burocracia, rompendo as funcionalidades, as complementaridades e as sinergias dos sistemas produtivos (MOSCA, 2005).

272 Por exemplo, de produtos químicos, das máquinas e equipamentos, etc.

${ }^{273}$ Esta orientação (que é posterior ao III Congresso) demonstra simultaneamente o reforço e a debilidade (ou os fracassos) da política da FRELIMO para o meio rural. Pretendiam-se os seguintes objetivos: Obter receitas como forma de reduzir os prejuízos das E.E.; Controlar os outros setores de produção transformando as empresas estatais em extensões do Estado para algumas funções; Criar mecanismos de dependência e de relacionamento desequilibrado que terminaria por reforçar a política da FRELIMO e o padrão de acumulação centrada no Estado; Aumentar a produção.
} 
instabilidade dos trabalhadores não permitia a realização das operações culturais. As empresas começaram a ter a suas próprias forças militarizadas (as milícias populares), que eram trabalhadores com treino e estrutura de comando próprio $^{274}$.

As empresas demonstraram desta forma que não eram só apenas uma forma de organização econômica ou conseqüência de uma ação ideológica ${ }^{275}$. As empresas estatais eram também um instrumento de poder, de soberania e de transformação econômica, que deveriam assumir o papel de vanguarda econômica e o exemplo da modernização para o desenvolvimento econômico. O setor estatal era, ideologicamente, a "forma superior de produção", por ser "propriedade do povo". Em termos organizacionais, as E.E., seguiam um modelo de especialização ramal através de grandes empresas monopolistas ou por várias empresas dirigidas por um órgão estatal do respectivo ramo (as Unidades de Direção), dirigido verticalmente por órgão do Estado que decidiam sobre as funções estratégicas de gestão como o investimento, a inovação, o financiamento e as relações com o exterior. As E.E. Tinha ainda uma função fundamental da defesa e afirmação do poder. Elas eram o instrumento de aplicação da política econômica, para concentrar a acumulação ${ }^{276}$.

Este conjunto de aspetos associado a uma gestão deficiente dos setores sociais (educação, saúde, etc.), incluídos marginalmente, sobretudo como fonte fornecedora de recursos. Aprofundou a crise econômica das empresas, justificada em parte pelos custos que se aprofundavam pela defesa e segurança. Assim como, as aldeias comunais eram contempladas nos orçamentos dos governos provinciais e nas ações dos governos distritais, o que cria uma dualidade, ocasionada por a economia centralizada e dirigida pelo Estado e, por outro lado, os setores sociais e as aldeias comunais, eram posta em pratica de forma descentralizada e cujo desenvolvimento dependia principalmente de recursos locais, podem ser interpretados de diferentes formas ${ }^{277}$. O objetivo principal do governo era a estatização da economia onde deveriam ser concentrados os recursos e que o objetivo de importância secundaria ficavam sob a

\footnotetext{
${ }^{274}$ Algumas empresas possuíam importantes forças de milícias que protegiam as infra-estruturas e os trabalhadores, eram responsáveis pelas colunas de proteção da viatura em viagem; existiram empresas, cujas milícias participavam em ataques as bases militares da RENAMO juntamente com o exercito da FRELIMO.

${ }^{275}$ Cardoso (1993) faz um resumo do conceito de empresa estatal e apresenta uma resenha sobre o surgimento e desenvolvimento do setor estatal na África subsaariana. Apresenta as razões de natureza ideológica, econômica, sociológica, organizacional e refere às origens e o desenvolvimento do setor estatal em África, bem como o peso destas empresas nas economias subsaarianas.

${ }^{276}$ Ibidem.

${ }^{277}$ Ver. Mosca (1999).
} 
responsabilidade dos órgãos locais. Os serviços foram passados para o segundo plano, quanto à afetação de recursos, recorrendo-se á iniciativa local e ao principio de "contar com as próprias forças" para melhorar a oferta. Na realidade, os investimentos de âmbito local representaram em 1978 e 1979 apenas 0,3 por cento do total dos investimentos público no mesmo período ${ }^{278}$.

O dilema entre a centralização e a descentralização e entre o autoritarismo e a participação democrática foram sempre elementos do debate interno no movimento de libertação e que assumiram em cada momento diferentes formas de aplicação. Este aspeto operacional pode ser relacionado com a dominação da aliança populista-esquerda radical na direção da FRELIMO. Os primeiro, mais preocupados com a vida dos cidadãos e com experiência em métodos de auscultação e de relacionamento com as comunidades; os segundos, mais técnico e preocupado com o plano e com a organização da economia. Importa referir que o plano era um instrumento do poder e de implantação de um modelo econômico e refletia as opções políticas e ideológicas da FRELIMO. De forma coerente com estas opções, os camponeses apenas eram contemplados no plano na medida em que produziam excedentes de produção; os privados eram na sua maioria marginalizados e apenas contemplados quando as produções tinham importâncias, sobretudo para a exportação e para o abastecimento interno ${ }^{279}$.

O plano desenvolvimentista traçou o modelo econômico que reproduziram posteriormente elementos da crise interna e externa que o país enfrentou ${ }^{280}$. As medidas de emergência, conforme já referido, não eram apenas conseqüência da evolução precipitada dos acontecimentos (saída dos portugueses e dos empresários, atos de sabotagem, inicio do conflito interno, ruptura nas relações externas, etc.), mas correspondiam com opções políticas e, muitas delas, pretendiam preparar a aplicação de uma política econômica assente em paradigmas completamente diferentes dos anteriores ${ }^{281}$.

\footnotetext{
278 Ver. COMISSÃO NACIONAL DE PLANOS (1985).

279 O plano definia o que, como e onde produzir como distribuir a produção, controlava os recursos, determinava quem eram os responsáveis das empresas através de nomeação das direções e, no fim, controlava, pedia contas e podia punir o não esforço do planejamento, as medidas, aparentemente de emergência, perduraram no tempo. Assim, as políticas de emergência, que pareciam razoáveis como mediadas temporárias, atingiam uma permanência que era insustentável em longo prazo (HERMELE, 1988).

${ }^{280}$ Como o caso: (1) dos transportes estarem focalizado essencialmente ao fornecimento de serviços aos países vizinhos; (2) a falta de quadros capazes de assegurar o funcionamento da economia; (3) Exportação da força de trabalho; (4) A queda dos preços do mercado internacional, em especial dos produtos importados por Moçambique. O que aumentou a absorção do esforço da produção nacional (MOSCA, 2005).

281 Não obstante o período descrito como de transição, existiram sinais que aparentavam alguma recuperação econômica entre 1977 aos 1981. Existiam empresas que tinham recuperado a produção até aos níveis próximos aos dos últimos anos do período colônia; os recursos externos dos países socialistas eram avultados; a FRELIMO e o
} 
Entretanto, o período de transição se caracterizou por um aprofundamento importante da crise no fim da época colonial. Mas os dirigentes da FRELIMO não o consideravam grave; referia que era a crise do sistema capitalista em Moçambique, era em parte provocada pela FRELIMO com objetivo de destruir as bases do sistema, as formas de organização da economia, a eliminação de possibilidade de emergência de "novos exploradores" e a ruptura com os parceiros capitalistas para alterar os laços de dependência e anular os interesses do capital exterior do país. Na crise, e com a ruptura e eliminação do capitalismo, seria mais fácil criar as bases materiais para a construção do socialismo ${ }^{282}$.

Os aspetos acima demonstrados pela ortodoxia da FRELIMO impediram análise das realidades e que existia desconhecimento (ou negligência) sobre os mecanismos de funcionamento e de transformação cultural e econômica: o radicalismo e o populismo dos militantes, oriundos das elites locais e dos intelectuais formados na Europa e nos EUA, originaram aplicações descontextualizadas do marxismo com rejeição dos poderes locais e dos valores culturais da sociedade e transpuseram de forma mecânica as experiências das zonas libertadas. Estes aspetos, combinados provocaram a crescente separação da FRELIMO das suas bases sociais, que se mantiveram hibernados pelos objetivos prioritários e imediatos que era a causa da independência, aguardando oportunidades para retomar a luta ideológica e pelo $\operatorname{poder}^{283}$.

governo demonstravam, em alguns casos, boa capacidade organizacional; existia uma grande mobilização e receptividade da maioria da população e dos quadros para aplicar as opções da FRELIMO; a RENAMO atuava, sobretudo no Centro do país e a ação de desestabilização não afetava a economia de forma muito significativa; os movimentos de libertação na África Austral tinham perspectiva de vitória de curto prazo; existia expectativa, em todo o quadrante, sobretudo a experiência moçambicana (HERMELE, 1988).

${ }^{282}$ Em síntese, o discurso político e as decisões durante o período de transição refletem claramente os aspetos seguintes: $\mathrm{O}$ radicalismo ideológico assente em dois pilares: o marxismo ortodoxo e o populismo, onde o autoritarismo, o centralismo e a concentração dos poderes e do controlo eram complementados com a instrumentalização da participação das massas e alguma democracia direita ao nível da base e das massas e alguma democracia direta ao nível da base e interna (nos órgão da FRELIMO); As opções e o ideário político e ideológico são conseqüência de um conjunto de fatores, como a experiência da luta de libertação nacional, principalmente a administração das zonas libertadas, as lutas internas e a natureza do conflito (luta anti-colonial com um regime fascista e o fato de ser uma guerra de guerrilha), de fatores externos (apoio dos países socialistas) e da composição de classe da direção do movimento de libertação; A "Fe" na mobilização do povo e no principio de "contar com as próprias forças" como contraponto com a necessária aliança com a nova elite tecnocrata recém-formada; A subestimação da agressividade da Rodésia e da África do Sul e das dinâmicas que se poderiam gerar dentro da RENAMO e do conflito regional e, por outro lado, a superestimação da capacidade da FRELIMO e da mobilização da população (MOSCA, 2005).

${ }^{283}$ A análise do processo Moçambicano é geralmente realizada com uma das duas ênfases seguintes: os fatores internos ou os externos. Adam (1996) e outros autores fazem um resumo das principais contribuições cada uma das aproximações e propõe uma abordagem que associa as contradições internas com as influências externas. Destacando das primeiras: As análises deficientes das realidades e a tendência para a homogeneização, a criação de 
A questão agrária de Moçambique neste plano centrava-se em volta das cooperativas, programadas como forma de produção coletiva, assente na propriedade da terra do Estado. Os camponeses dispersos, individualistas e conservadores, não constituíam uma forma de produção capaz de se modernizar. A cooperativa implicava geralmente a habitação em aldeias comunais e, portanto, o abandono total ou parcial das parcelas de produção familiar e das formas de habitação tradicionais com implicações sobre muitos aspectos históricos e culturais ${ }^{284}$. Porém, o processo cooperativo encontrou um primeiro obstáculo na posição de classe de elementos nos órgão estatais. Esta posição de classe manifestou-se quer sob forma de oposição subtil à cooperativização, quer sob a forma de uma relação paternalista com o movimento. Disto resultou o conflito entre o camponês que, com confiança no partido, aceita a idéia da cooperativa e o funcionário que a recusa ou ignora.

Este processo de um modo geral, deriva da falta de experiência e conhecimento, da ausência de uma cultura cooperativa no seio da comunidade. Entretanto, a análise burocrática do movimento cooperativo, está presente a concepção do processo introduzido de cima para baixo, da preocupação do controlo, da incapacidade do Estado, da burocratização do planejamento e da responsabilização do inimigo da classe ‘infiltrado' na burocracia ${ }^{285}$. Outro aspecto que marca a questão agrária negativamente e a falta de acesso á terra pelos camponeses como um dos erros

mito e a recusa por qualquer elemento que caracterizava o colonialismo e a aplicação irrealista de algumas experiências das zonas libertadas; Alguns autores, como por exemplo, Cahen, atribuem o falhando na política pósindependência porque a FRELIMO nunca foi um partido marxista-leninista; A política agrícola, sobretudo no que respeita á marginalização do campesinato, ás aldeias comunais e ás opções de tecnologia intensiva em capital nas empresas estatais (MOSCA, 2005).

${ }^{284}$ Mosca (2005) apoud Mistério da Agricultura (1982): 'ao fim de alguns anos de experiência, fez um balanço sobre o movimento cooperativo e, em resumo, concluiu As cooperativas de produção agrárias nunca foram convenientes planificadas. A correspondência entre as áreas planificadas, qualificadas por cálculos de gabinete, com as áreas realimente definidas e trabalhadas, raramente foi fisicamente controlada; Os dados relativos às áreas lavradas, semeadas, sachadas e colhidas foram sempre incertos e até por vezes contraditórios, devido á falta de controlo físico seguro, realizado quer pelos próprios cooperativistas quer pelas estruturas de apoio; O controlo da produção material, devido às dificuldades próprias, á organização interna das cooperativas e às esporádicas e rápidas visitas das estruturas de apoio, não ofereceram a possibilidade de uma avaliação real e correta de produção nos seus aspectos quantitativos e financeiros. A falta de balança, de armazém, de registro, etc., facilita a prática de elaboração de cálculos estimativos que, por vezes, permitem em muitos casos elaborar relatórios e formar informações manifestamente adulteradas; Ausência de diretivas simples sobre a distribuição do produto material, do esforço coletivo criou situação de desmobilização. Por outro lado, é necessário contrapor á frieza e rigidez dos números apresentados a extraordinária riqueza e diversidade de experiências que esses números escondem.

${ }^{285}$ De acordo com Mosca (2005) independentemente dos setores em análise, as conclusões sobre a evolução das realidades são nesta fase (princípio dos anos 1980) semelhantes: o não cumprimento das metas e das diretivas, a lentidão das transformações, etc., tenham as seguintes justificações: $O$ inimigo e a posição de classe dos funcionários que se reduzem, entre outros aspectos, a um gradual isolamento do Estado em relação ao povo; as dificuldades materiais e logísticas; a falta de experiência; os favores externos, designadamente a crise do capitalismo, os termos de troca e a importação da inflação. 
fundamentais da política econômica da FRELIMO. Porém, a radicalização na planificação e os dilemas entre os mecanismos de uma economia centralizada e o mercado, a marginalização de importantes setores econômicos (como os de pequena escala e o privado) e as alterações das alianças de classe da FRELIMO após a independência referenciados ao longo do texto, como por exemplo: Adam, Casal, Hanlon, Hermele, Mosca, Negraõ. A construção de um Estado burocratizado, centralizado, com o poder concentrado que fez emergir uma elite cada vez mais dissociada das realidades e dos ideários da FRELIMO.

Associando estes fatores aos fatores externos, destacamos; As influências diretas e indiretas sobre a política interna, principalmente exercida pela ex-URSS, China, países nórdicos (sobretudo a Suécia) e Tanzânia, o que se traduz pela aplicação mecanicista de modelos econômicos sem considerar as realidades. Neste contexto, a guerra de desestabilização, os conflitos regionais e a Guerra Fria tiveram graves efeitos sobre a população e o tecido social, a produção, as infra-estruturas e o funcionamento da economia ${ }^{286}$. Porém, outros fatores importantes para o fracasso do PEC foram; a evolução da economia internacional, sobretudo no que respeita á evolução dos termos de troca, as ações de sabotagem de muitos parceiros econômicos e comerciais externos.

\footnotetext{
${ }^{286}$ Também nestes aspectos existem autores que referem as causas externas como as mais importantes no quadro de análise da Guerra Fria e da importância da África Austral; outros, embora aceitando a importância dos apoios e de algumas origens externas da guerra, consideram que foi os efeitos da política econômica da FRELIMO e das alianças sociais pós-independência que permitiram a reprodução e alargamento da guerra.
} 


\section{VIII-CAPÍTULO \\ Plano Prospectivo Indicativo (PPI)}

Este capítulo, com o título, Plano Prospectivo Indicativo (PPI), tem como objetivo mostrar como PPI procurava consolidar as diretrizes econômicas socialista em Moçambique. Entretanto, este capítulo esta subdividido em cinco tópicos: $\mathrm{O}$ primeiro é denominado A estratégia de reconstrução econômica. Este tópico procura mostra como foi à estratégia de reconstrução econômica do segundo processo revolucionário socialista em Moçambique, que teve inicio com PPI. O segundo com o tema Crescimento econômico. Faz uma menção ao Crescimento econômico de Moçambique durante a execução do PPI. O terceiro, com o tema $O$ setor agrário, faz uma caracterização da exploração agrária de Moçambique durante a implementação do PPI. Entretanto, faz referencia ao desenvolvimento de algumas empresas estatais do ramo agrário em que foram concentraram elevados volumes de investimentos públicos e foi à priorização na afetação de recursos após a independência. Quarto topico tem como tema o setor industrial, objetiva caracterizar o setor industrial durante a implementação do Plano Prospectivo Indicativo (PPI). Num período em que o setor industrial foi objeto de protecionismo, como eram autorizadas importações de bens correntes com a produção nacional e as exportações de matérias para abastecimento das fábricas. Quinto tópico, com o tema $O$ setor do transporte, caracterizar a situação do setor dos transportes durante a implementação do PPI. Porém, mostra como foi se procedendo a evolução política do transporte em Moçambique, o seu funcionamento e dificuldades para o reforço da idéia de um projeto de desenvolvimento econômico socialista a um longo prazo.

\subsection{A Estratégia de Reconstrução Econômica}

Este tópico procura mostra como foi à estratégia de reconstrução econômica do segundo processo revolucionário socialista em Moçambique, que teve inicio com o Plano Prospectivo Indicativo (PPI). Um plano aprovado para 10 anos (1980-1990) era principalmente um conjunto de metas econômicas e sociais, um guia de ação e instrumento fundamental para a construção e desenvolvimento de uma economia socialista. Porém o plano foi desenvolvido dentro das 
diretrizes do III Congresso, para reforçar os sinais que se aparentavam na economia de alguma recuperação entre 1977 aos $1981^{287}$. Nesta perspectiva o PPI tinha como objetivos celebrar a vitória sobre o subdesenvolvimento e a construção de um país socialista ${ }^{288}$.

Assim sendo, no PPI a economia foi reorientada partindo dos eixos centrais definidos na socialização do campo e desenvolvimento agrário, que pesavam fundamentalmente para dois fatores; (1) o desenvolvimento acelerado do sector estatal agrário (com base na grande exploração agrária e na mecanização, realizadas principalmente, através dos grandes projetos que respondessem às necessidades do povo e tornassem o setor estatal dominante na economia nacional) e; (2) na cooperatividade do campo (transformação de milhões de camponeses num forte campesinato socialista edificado sob novas relações de produção) ${ }^{289}$.

Para tal, o PPI deveria fortificar a expansão da criação das cooperativas, com o envolvimento dos camponeses num modo de vida coletivo nas (Aldeias Comunais), onde sairia à força de trabalho, disponível para a produção, dotadas de normas e metodologias socialistas massificadas no trabalho. De uma forma sumária a estratégia de reconstrução econômica ${ }^{290}$ contemplava duas fases no eixo da Industrialização. Primeiro, o investimento forte na indústria ligeira em articulação com o sector agrícola com o objetivo de garantir as necessidades básicas da população e promover as indústrias de exportação. O objetivo era o da criação de um sector estatal forte quer na indústria pesada com maior enfoque para a exploração da indústria de ferro e aço, que tinha em vista o aumento do nível de produção e de produtividade dos grandes projetos agrícolas. Assim, o plano promoveu a agroindústria, com a introdução das tecnologias avançadas

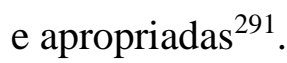

O plano procurou desenvolver as infra-instrutoras para a comercialização dos

${ }^{287}$ Existiam empresas que tinham recuperado a produção até aos níveis próximos aos dos últimos anos do período colônia; os recursos externos dos países socialistas eram avultados; a FRELIMO e o governo demonstravam, em alguns casos, boa capacidade organizacional; existia uma grande mobilização e receptividade da maioria da população e dos quadros para aplicar as opções da FRELIMO; a RENAMO atuava, sobretudo no Centro do país e a ação de desestabilização não afetava a economia de forma muito significativa; os movimentos de libertação na África Austral tinham perspectiva de vitória de curto prazo (MOSCA, 2005).

288 "O Presidente Samora Machel declara os anos 1980 como a Década da Luta contra o Subdesenvolvimento e proclama as Campanhas Políticas e Organizacionais (1980 e 1981). Do ponto de vista político-ideológico estas campanhas constituem uma espécie de autocrítica do regime através das quais Samora Machel procura motivar os moçambicanos a aceitarem uma série de medidas, muitas delas de caráter contraditório" (CARVALHO, 2008. 108). ${ }^{289}$ Ver. Mosca (2005).

${ }^{290}$ Os principais instrumentos desta política econômica consistiam na formação de um sector estatal forte visando à reestruturação das empresas estatais existentes e adequar as condições em que as empresas intervencionadas se poderiam transformar em empresas públicas e na subordinação das atividades econômicas ao sistema de planificação central e do centralismo democrático (CARVALHO, 2008).

${ }^{291} \mathrm{Ibdem}$. 
excedentes da produção agrária, introduzindo em algumas áreas regadio e sequeiro para a conservação da potencialidade da terra, procurando transformar a produção agrícola numa atividade rentável. Com a integração do programa de cooperatividade e desenvolvimento do setor estatal agrário, o Plano Prospectivo Indicativo propôs a transformar a base socioeconômica do setor familiar, envolvendo os camponeses no modo de vida coletiva nas aldeias comunais, com produção coletiva centrada nas cooperativas e na produção individual. O seu programa de desenvolvimento do setor estatal agrário abarcava os projetos agrários para a substituição das importações, onde, com o projeto de ferro e aço, se construiriam as máquinas químicas de base e se aumentariam os projetos de exportação do carvão e do alumínio ${ }^{292}$.

A primeira fase do Plano Prospectivo Indicativo começaria com a produção de aço, alfaias e instrumentos agrícolas, caminhões, procurando aumentar a produção de carvão, vagões, autocarros, cimento, varões de construção e pedras. Na segunda fase, o destaque vai para a produção do alumínio, laminados, carris, fertilizantes, tratores, aumento da produção do carvão, autocarros, alfaias agrícolas, o aumento da produção regional e temporal da energia, para garantir os grandes projetos e procurar investir na rede de transporte e distribuição. Outros ramos da indústria procuravam maximizar a produção para exportação e para abastecimento do povo, aproveitando do comércio virado ao escoamento da produção agrícola de diferentes setores, Esta situação era como base nos planos e metas da produção, dividida por tarefa em ramos de atividades, onde o trabalho geológico esteve dentro dos objetivos do desenvolvimento da indústria pesada ${ }^{293}$.

Pela necessidade de aumentar as exportações nos grandes projetos industriais, se estabeleceram cronogramas de trabalho do reconhecimento da zona prioritária e elaboração de inventário e prognósticos da balança dos recursos minerais existentes. Assim sendo, a prioridade se centrava nos mineiros não metálicos, usadas na indústria de alumínio, construção, cerâmica, vidro e papel, assim como o caso das pesquisas do petróleo e gás. O investimento e construção estiveram concentrados nos programas relacionados com a materialização dos objetivos gerais do plano e tinha em vista à garantia do potencial produtivo e ações para o desenvolvimento da sociedade $^{294}$.No plano o desenvolvimento dos transportes e comunicações tinha em vista as necessidades dos setores de escoamento da produção dos grandes projetos, passando pela

\footnotetext{
${ }^{292}$ Ibidem.

${ }^{293}$ PLANO PROSPETIVO-INDICATIVO PARA A DÉCADA DE 1980 (1981).

${ }^{294}$ Ver. HAMELA, Hipólito. Moçambique: Economia de Mercado ou Socialismo do Capital?Maputo: Ndjira, 2003.
} 
coordenação das atividades dos tipos de transportes e meios de comunicação existentes para o escoamento internacional, e uma redução do uso de derivados de petróleo e eletrificação de algumas linhas de transportes. Posteriormente, as ações visavam criar um potencial necessário na formação e qualificação da força de trabalho. Na prática, a integração no componente de desenvolvimento social e nível de vida do PPI estavam orientados ao abastecimento da alimentação, habitação, educação ${ }^{295}$, saúde $^{296}$, transporte e comunicação.

\subsection{Crescimento Econômico}

Este tópico faz uma menção ao crescimento econômico de Moçambique durante a execução do Plano Prospectivo Indicativo (PPI). Porém, depois da década dos anos 1970, bem como anteriormente, a evolução política de Moçambique, teve uma forte influência nas decisões econômicas. Destacados fundamentalmente os seguintes aspetos econômicos de Moçambique neste período ${ }^{297}$. A libertação política do país foi acompanhada de uma explosão de afirmação cultural e de identidade nacional, em redor de um movimento de libertação e posteriormente de um partido que congregava o apoio e possuía legitimidade de uma grande maioria da população em conseqüência de representar a independência e possuir um discurso libertador e em defesa

295 A educação para a FRELIMO era um setor importante por diferentes razões: para a construção do socialismo na perspectiva da modernização da economia e introdução de novas tecnologias nas empresas estatais e nas cooperativas; para o reforço e capacitação do aparelho de Estado que se pretendia ser o protagonista na direção e no controlo da economia através do plano; como forma de difusão da política e da ideologia do partido e de "consciencialização" das massas. A FRELIMO assumiu a educação como um importante setor para o controlo ideológico. As carências de quadros eram imensas, tendo-se priorizado a satisfação das necessidades de curto prazo; finalmente, porque os primeiros estudantes graduados eram majoritariamente originários da elite colonial em relação à qual a FRELIMO estabeleceu uma aliança cuidadosa e desconfiada. Os que ficaram em Moçambique na universidade eram também, na sua larga maioria, filhos da pequena e média burguesia colonial que, por razões diversas, optaram por permanecer no país. Foram estes jovens que ocuparam lugares importantes na administração, sobretudo nas empresas intervencionadas e nacionalizadas e no aparelho do Estado (MUNSLOW, 1983).

${ }^{296}$ As políticas e a evolução na área da saúde foram semelhantes ao verificado na educação. Foi dada prioridade à saúde preventiva e tiveram maior importância os cuidados de saúde primários. O objetivo era mesmo: ampliar as acessibilidades e a cobertura sanitária e a universalização da saúde. Portanto, estas políticas foram acompanhadas da política de medicamento dos Ministérios da Saúde, principalmente com a criação da Empresa Estata de Medicamentos de Moçambique (MEDIMOC). Empresa Estatal (E.E) que importava, exportava e geria todas as farmácias do país, definia listas de medicamentos para efeitos de importação e fabrico local e para orientação das prescrições medidas (HANLON, 1996).

297 Samora Machel respondeu da seguinte forma às tentativas de Spinola acerca de um referendo sobre a independência (idéia de recurso das forças com interesses em Moçambique para formar uma Federação de Estados): "não se pergunta a um escravo se quer ser livre e muito menos quando ele já se revoltou" e com promessas de continuação da Guerra (MOSCA, 2005). 
dos colonizados e dos pobres ${ }^{298}$.

A evolução aparentemente positiva entre 1975 e 1981, foi devido ao crescimento econômico ter alcançado ritmos bastantes elevados, cerca de 5 por cento. Neste período, a maioria dos indicadores econômicos teve comportamentos positivos: a taxa de inflação do mercado oficial esteve controlada (entre 1 e 2 por cento); as contas públicas mantiveram-se equilibradas; contrariamente ao consumo público, o consumo privado aumentou; as exportações cresceram (embora as importações tivessem crescido mais rapidamente); a produção aumentou em quase todos os setores, etc ${ }^{299}$ :

TABELA11.

Produção social global (a preços constantes de 1980).

\begin{tabular}{|l|c|c|c|c|c|l|}
\hline & 1975 & 1977 & 1980 & 1982 & 1984 & 1986 \\
\hline Produção social global (PSG) & 71.1 & 75 & 82.1 & 78,8 & 58,2 & 56,2 \\
\hline PSG agrícola (\%) & - & - & 37,5 & 39,1 & 41,9 & 48,7 \\
\hline Taxa de crescimento real, base 1980 & - & 5.6 & 4,4 & $-6,3$ & $-9,6$ & 4,3 \\
\hline Índice de preços ao consumidor anual & - & 1 (a) & 2 (a) & 17,6 & 30,3 & 16,9 \\
\hline
\end{tabular}

(a) Inferior a 2 por cento por ano, considerando apenas o mercado formal.

Fonte: Mosca (2005) citada para os anos 1975 e 1977, CNP (1985), Informações Estatísticas, 1975-1984. Ministério da Agricultura (1987). Para os restantes anos, CNP (1987) Informações Estatísticas, 1986.

A tabela revela que o consumo privado, em percentagem do PIB, cresceu. Os preços constantes de 1980, o mesmo decresceu a brutamente depois de 1981-1982. Não existem dados entre 1975 e 1980. Pelo método de relacionamento os agregados macroeconômicos básicos (consumo, investimentos, gastos públicos, exportações), são possíveis confirmar a percepção da realidade $^{300}$. Não contrariando a percepção da realidade vivida e encontrando coerência com a

\footnotetext{
298 Não obstante as não-alianças de natureza étnicas ou a quebra das expectativas de muitos grupos sociais após a independência, ou ainda as políticas desajustadas principalmente em relação ao desenvolvimento rural que afetaram negativamente a vida dos camponeses, existe um elevado consenso (mesmo dos autores críticos), em como se verificaram importantes progressos, durante os primeiros anos, na prestação dos serviços de educação e de saúde (ADAM, de 1993).

${ }^{299}$ A política do período pós-independência apresentou alguns elementos econômicos, aparentemente positivos entre 1977 e 1981, os elementos da crise imediata após-independência se atenuaram e, por outra, a economia recebeu recursos externos importantes e existiu uma reorganização do Estado e do tecido produtivo (BRUCK, 1998).

300 A expansão nos gastos correntes do Estado, dos investimentos públicos, e o crescimento do déficit da balança comercial a ritmos superiores ao crescimento econômico implicaram, necessariamente, uma retração do consumo privado por um lado e o financiamento público com emissão de moeda. Ao nível micro aconteceu a contenção salarial, a manutenção dos níveis de emprego e os resultados financeiros negativos da empresas estatais provocaram excesso de procura (ou difícil da oferta). Estes fatores contribuíram para que surgisse a economia informal e o mercado paralelo com inflação, como resposta aos controlo administrativos dos preços e aos desequilíbrios entre a oferta e a procura (WUYTS, 1989 e 1991).
} 
política de novas alianças sociais, os dados são acrescidos acessibilidade aos serviços que aumentaram como consequiência das nacionalizações e do sentimento de liberdade que existia para maior dos cidadãos ${ }^{301}$.

A tabela anteriormente apresentado demonstra que o consumo público cresceu até 1982 (o que é confirmado posteriormente com as despesas correntes e de investimentos) e, com as reformas, o decrescimento foi mais rápido que o consumo privado. Em qualquer dos casos, a queda do consumo foi muito violenta: em quatro anos, tendo como base 1980, existiu uma redução em mais de 31 por cento no consumo privado e cerca de 40 por cento no público. A evolução do consumo privado imediatamente após a independência deve-se principalmente à subida dos salários descontrolados e de má-fé realizados por muitos empresários antes de abandonarem o país:

\section{GRÁFICO 5.}

Fundo de salários (Salários reais e nominais).

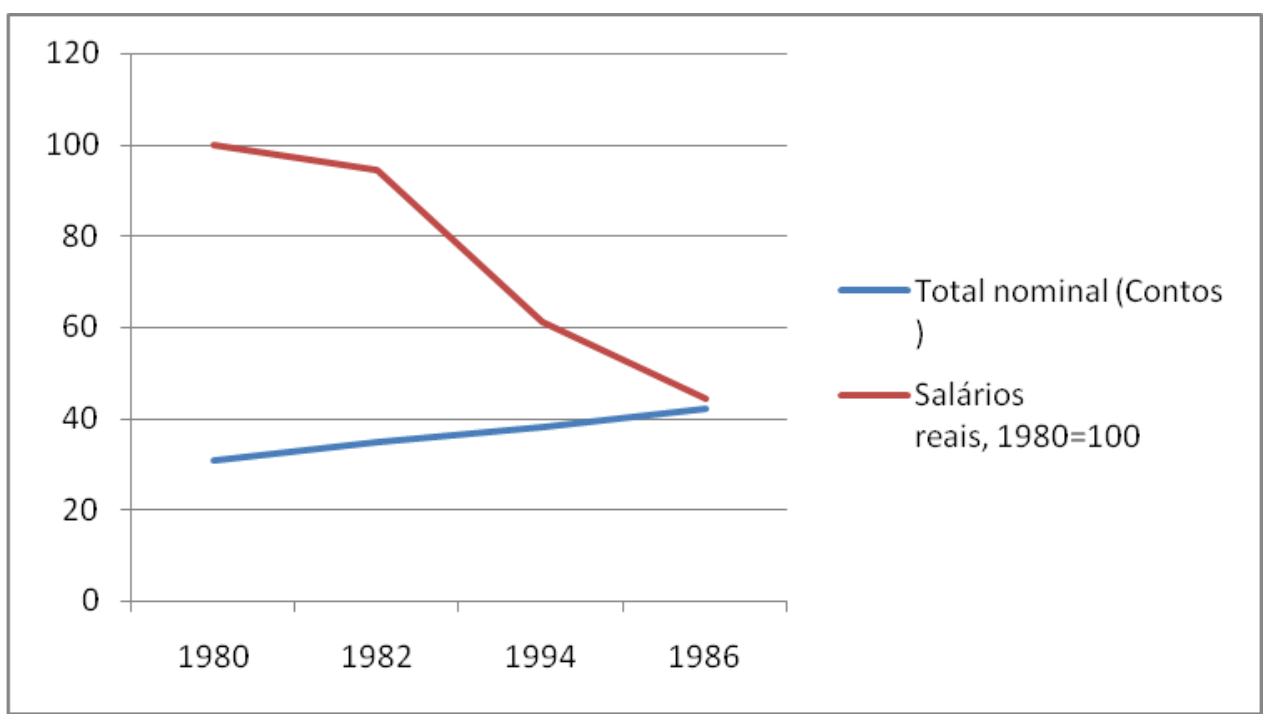

Fonte: Adaptado de Mosca (2005), apund Informações Estatísticas, 1986.

Os dados do consumo são coerentes com a política econômica do socialismo de manutenção do emprego independentemente da produção da empresas e conter a procura privada para concentrar os recursos e a capacidade de investimento no Estado.

301 Segundo Mosca (2005), é possível admitir que o nível de vida melhorasse, sobretudo para os citadinos; principalmente para estes devido à concentração do emprego e dos serviços nos centros urbanos. 
TABELA 12.

Consumo e investimentos (10 contos)

\begin{tabular}{|l|c|c|c|c|}
\hline \multicolumn{1}{l|}{} & 1980 & 1982 & 1984 & 1986 \\
\hline Consumo total & 77,8 & 81,5 & 115,8 & 160,1 \\
\hline Consumo privado & 64 & 76,6 & 93,3 & 133,2 \\
\hline Percentagem do PIB & 81,8 & 82,9 & 85,5 & 84,8 \\
\hline A preços de 1980 & 64 & 62,7 & 46,2 & 43,7 \\
\hline $1980=100$ & 100 & 98 & 72,2 & 68,3 \\
\hline Consumo público & 13,8 & 18,9 & 22,5 & 26,9 \\
\hline Percentagem do PIB & 17,6 & 20,5 & 20,6 & 17 \\
\hline A preços de 1980 & 13,8 & 15,8 & 11,1 & 8,8 \\
\hline $1980=100$ & 100 & 114,5 & 80,4 & 63,8 \\
\hline Formação interna bruta de capital (\% do PIB) & 14,8 & 17,9 & 11,4 & 16,3 \\
\hline Percentagem do PIB & 18,9 & 19,3 & 10,5 & 10,3 \\
\hline A preços de 1980 & 14,8 & 14,9 & 7,2 & 5,4 \\
\hline $1980=100$ & 100 & 101 & 48,6 & 36,5 \\
\hline
\end{tabular}

Fonte: Mosca (2005) citada CNP (1987). Informações Estatísticas, 1986.

O orçamento público revela que as contas correntes se mantiveram equilibradas até meados da década dos anos 1980. No entanto, se aos gastos correntes forem acrescentados os investimentos públicos, significa que o déficit alcançaria o Maximo em 1986, com cerca de 40 por cento do PIB:

TABELA 13.

Orçamento público (em 10 contos)

\begin{tabular}{|c|c|c|c|c|c|c|}
\hline \multicolumn{1}{|c|}{} & 1975 & 1977 & 1980 & 1982 & 1984 & 1986 \\
\hline Receitas & 6,2 & 7,1 & 14,8 & 21 & 22,3 & 20,3 \\
\hline Receitas: $1980=100$ & 2,3 & 1,6 & 100 & 118 & 74,6 & 55 \\
\hline Impostos diretos & 3,6 & 5 & 4,3 & 6,3 & 6,6 & 6,3 \\
\hline Impostos indiretos & 6,1 & 8,3 & 8,3 & 9,1 & 9,8 & 8,7 \\
\hline Despesas & 8,6 & 11,1 & 14,1 & 19,5 & 22,9 & 27,4 \\
\hline Despesas: 1980=100 & 18,3 & 20 & 100 & 115,2 & 80,4 & 63,7 \\
\hline Percentagem do PIB & 8,6 & 12,7 & 17,2 & 24,7 & 39,3 & 48,8 \\
\hline Percentagem em educação & $+0,1$ & $-1,2$ & 17,7 & 20,0 & 17,9 & 16,8 \\
\hline Percentagem em saúde & & & 10,6 & 10,3 & 7,4 & 6 \\
\hline Déficit & & & $+0,7$ & $+1,5$ & $-0,6$ & $-7,1$ \\
\hline
\end{tabular}


Fonte: Mosca (2005) citada CNP (1987). Informações Estatísticas, 1986.

Nas despesas correntes, pode-se verificar que o peso inicial da educação e da saúde decresceu a partir de metade dos anos 1980. Segundo a Informação Estatística de 1989, as despesas militares alcançaram os 46,2 por cento do total de gastos públicos correntes em 1985 e as subvenções (majoritariamente subsídios ao consumo e às empresas estatais), variavam muito, tendo alcançado quase 35 por cento em 1986 (apenas 2 por cento em 1984 e 15,3 por cento em $1986^{302}$. Os investimentos públicos foram em geral elevados, com decrescimento no período das reformas. Considerando aproximados os conceitos de formação bruta de capital fixo (FBCF) e de investimentos, pode-se verificar o peso do investimento público. A agricultura e a construção (com um grande peso de construção de infra-estruturas agrícolas) eram os principais setores beneficiados $^{303}$.

\section{TABELA 14}

\section{Investimento total (em 10 contos)}

\begin{tabular}{|l|c|c|c|c|c|}
\hline \multicolumn{1}{l|}{} & $1978 / 79$ & 1980 & 1982 & 1984 & 1986 \\
\hline Formação bruta do capital fixo & - & 14,8 & 17,9 & 11,4 & 16,3 \\
\hline Total do Investimento Público & 8 & 9,9 & 14,3 & 10,6 & 12 \\
\hline Total a preço de 1980 & 8,3 & 9,9 & 11,9 & 5,2 & 3,9 \\
\hline Percentagem do PIB & - & 12,7 & 15,5 & 9,7 & 7,6 \\
\hline $1980=100$ & 83,8 & 100 & 120,2 & 76,4 & 39,4 \\
\hline Agricultura (\%) & 13,8 & 23,2 & 33,6 & 13,2 & 10 \\
\hline Construção e águas (\%) & 68,8 & 33,3 & 16,8 & 24,5 & 44,2 \\
\hline
\end{tabular}

Programa bienal.

Fonte: Mosca (2005) citada para os anos 1975 e 1977, CNP (1985), Informações Estatísticas, 1975 -1984. Para os restantes anos, CNP (1987) Informações Estatísticas (1986).

O setor externo foi sempre importante na economia moçambicana, considerando os seguintes aspectos: O déficit crônico da balança comercial, com valores superiores a 20 por cento do PIB e várias vezes o volume das exportações; A baixa ou muita baixa taxa de cobertura das importações pelas exportações; $\mathrm{O}$ crescente peso dos donativos; A passagem da balança de

\footnotetext{
${ }^{302}$ A guerra, os subsídios as empresas estatais e aos setores sociais, somavam entre 60 e 70 dos gastos públicos em meados dos anos 1980, CNP, Informação Estatística (1989). O déficit público, netas condições, era financiado com o incremento da ajuda externa, a receita proveniente da venda de donativos passou a ser uma importante fonte financeira do déficit público, representando mais de 50 por cento nos primeiros anos do PRE (MOSCA, 1999).

${ }^{303}$ Ibdem.
} 
serviços a negativa a partir de meados da década dos anos 1980, em conseqüência da saída dos mineiros moçambicanos e da redução do tráfego de mercadorias do hinterland pelos caminhos de ferro e portos moçambicanos; O volume e o crescimento da divida externa ${ }^{304}$.

Entretanto, foram definidas metas ambiciosas (irrealistas), como, por exemplo, o crescimento médio anual de cerca de 20 por cento. Porém, a evolução econômica entre 1977 e 1986 esteve assente em importações, com uma tendência da evolução mais rápida do valor das exportações entre 1978 e 1980 foi invertida, não obstante os termos de troca positivos do comercio externo entre 1980 e 1986.

Considerado o índice 100 para 1980, os valores para 1985 e 1986 foram respectivamente de 105 e 196. Deve-se, no entanto destacar que as variações podem ser grandes e não existem dados globais para os restantes anos do período em estudo. Pode-se observar na tabela 15 que mostra a balança de pagamento entre os anos de 1975 a 1986, fica claro que, na fase de crescimento, as importações são mais acentuadas, o que significa que o agravamento do déficit externo é constante $e^{305}$.

TABELA 15.

Balança de pagamento. 1975-1986. (contos 10)

\begin{tabular}{|l|c|c|c|c|c|c|}
\hline & 1975 & 1978 & 1980 & 1982 & 1984 & 1986 \\
\hline Balança comercial total (BCT) & $-5,7$ & $-11,9$ & -16 & $-22,9$ & $-18,8$ & 18,7 \\
\hline Exportações & 5 & 5,3 & 9,1 & 8,7 & 4,1 & 3,2 \\
\hline Importações & 10,7 & 17,2 & 25,9 & 31,6 & 22,9 & 21,9 \\
\hline Taxa de cobertura & 46,7 & 30,8 & 35,1 & 27,5 & 17,9 & 14,7 \\
\hline BCT/PIB (\%) & & 2,9 & 21,4 & 24,5 & 17,2 & 11,8 \\
\hline Balança de serviços & & 1,8 & 3,1 & 1,2 & $-1,4$ & $-5,3$ \\
\hline Donativos & & $\mathrm{Nd}$ & 1,8 & 3 & 7,1 & 8,6 \\
\hline Donativos: percentagem do PIB & & & 2,3 & 3,2 & 6,5 & 5,4 \\
\hline Balança de capitais & & & 11,8 & 14,9 & $-3,1$ & $-3,5$ \\
\hline Balança global & & & $-1,1$ & $-5,4$ & $-15,2$ & $-21,9$ \\
\hline
\end{tabular}

Fonte: Mosca (2005) citada para os anos 1975 e 1977, CNP (1985), Informações Estatísticas, 1975-1984. Para os restantes anos, CNP (1987) Informações Estatísticas, 1986.

Da Informação Estatística 1986 é possível retirar a evolução dos preços dos principais

\footnotetext{
304 Segundo Mosca (1993), recorda-se que a divida externa começou a avolumar-se a partir de finais dos anos 1970 e evoluiu rapidamente. Em 1986, o valor da divida era de 3150 milhões de dólares, numa primeira fase, sobretudo dos países socialistas; as exportações desse ano representavam somente 2,5 por cento da divida acumulada.

305 Ibidem.
} 
produtos moçambicanos. Considerado que os dados na tabela a seguir são produtos a mais importante das exportações pode-se, pelo menos, confirmar qualitativamente acrescentar que a mais rápida evolução positiva da economia se verificou entre 1975 e 1980, como mostra a tabela 16 acerca da evolução dos preços de alguns principais bens exportados;

TABELA 16.

Evolução dos preços de alguns principais bens exportados $(1975=100)$

\begin{tabular}{|l|c|c|c|c|c|}
\hline \multicolumn{1}{l|}{} & 1975 & 1980 & 1982 & 1984 & 1985 \\
\hline Açúcar & 100 & 245 & 227 & 292 & 343 \\
\hline Algodão & 100 & 189 & 194 & 234 & 199 \\
\hline Caju & 100 & 366 & 268 & 431 & 437 \\
\hline Chá & 100 & 184 & 240 & 370 & 360 \\
\hline Camarão & 100 & 313 & 325 & 415 & 406 \\
\hline Copra & 100 & 283 & 167 & 348 & 320 \\
\hline
\end{tabular}

Fonte: Mosca (2005), apund, CNP - Informações Estatísticas, 1986.

A tabela revela que as importações cresceram rapidamente entre 1975 e 1980/81 foi ainda mais acelerado. Se no primeiro período existiu um crescimento do volume e dos termos de troca, o comportamento entre 1981 e 1986 é reflexo da queda dos volumes ligeiramente compensada com os termos de troca. Tem importância ressaltar o peso crescente dos bens de consumo, sobretudo dos alimentares. A evolução do volume das importações está diretamente associada com a oferta nacional, que sofreu quedas rápidas a partir de 1981em quase todos os bens alimentares ${ }^{306}$. Esta queda do volume é pode ser verificada na tabela 17, que mostra os principais produtos importações e a tabela 18, que mostra as principais origens das importações;

\footnotetext{
${ }^{306}$ Aspetos que se podem observar são os seguintes; O surgimento dos países socialistas, sobretudo da URSS e da RDA, que alcançaram 26 por cento do volume das importações moçambicanas em 1984, ano da queda do muro de Berlim, com conseqüências importantes nas relações entre a RDA e Moçambique; O decrescimento das relações com países africanos, sobretudo com a RAS, que representava a maioria das importações de Moçambique precedentes da África; Relativamente as relações com os países socialistas da OCDE, destaca-se que Portugal perdeu várias posições no ranking dos países com quem Moçambique possuíam maiores relações externas (MOSCA, 2005).
} 
TABELA 17.

Importações, principais produtos (em percentagem do total de importações)

\begin{tabular}{|l|c|c|c|c|c|c|}
\hline \multicolumn{1}{l|}{} & 1975 & 1977 & 1980 & 1982 & 1984 & 1986 \\
\hline Total (10 contos) & 10745 & 10821 & 25922 & 31573 & 22903 & 21937 \\
\hline Total a preços de 1980 & 11732 & 11470 & 25922 & 26312 & 11338 & 7192 \\
\hline $1980=100$ & 45,3 & 44,3 & 100 & 101,6 & 43,7 & 27,7 \\
\hline Bens de consumo & 29 & 24 & 25 & 20 & 34 & 43 \\
\hline Alimentares & 14,5 & 10,3 & 13,5 & 13,8 & 25,0 & 27,5 \\
\hline Não alimentares & 14,5 & 13,7 & 11,5 & 6,2 & 9,0 & 14,5 \\
\hline Matérias primas & 41 & 46,4 & 48 & 45 & 36 & 29 \\
\hline Equipamentos & 16,7 & 14,4 & 19,1 & 21,7 & 17,3 & 16,8 \\
\hline
\end{tabular}

Fonte: Mosca (2005) citada para os anos 1975 e 1977, CNP (1985), Informações Estatísticas, 1975-1984. Para os restantes anos, CNP (1987), Informações Estatísticas, 1986.

Pode-se destacar que as exportações tiveram um comportamento qualitativamente semelhante às importações. Destacando-se uma subida do valor das exportações entre 1975 e 1980 se deve à evolução muito positiva dos termos de troca. Os parceiros comerciais entre 1975 a 1986 foram; os Países da Organização de Cooperação e de Desenvolvimento Econonico. $(\mathrm{OCDE})^{307}$, França, EUA, Itália, Portugal, Reino Unido, Republica Federal Alemã (RFA), Países socialistas $^{308}$, URSS, RDA, Países africanos, RSA:

\footnotetext{
${ }^{307}$ A sigla OCDE significa Organização de Cooperação e de Desenvolvimento Econômico, em 1947, no seu começo denominava-se Organização para a Cooperação Econômica (OECE). Com a entrada em vigor de uma nova convenção assinada pelos países associados, em 30 de Setembro de 1961 nasceu oficialmente a OCDE. uma organização internacional, composta por 34 países e com sede em Paris, França. A OCDE tem por objetivo promover políticas que visem o desenvolvimento econômico e o bem-estar social de pessoas por todo o mundo. O combate à corrupção e à evasão fiscal faz parte da agenda da OCDE o apoio aos governantes no sentido de recuperarem a confiança nos mercados e o restabelecimento de políticas saudáveis para um crescimento econômico sustentável no futuro.

${ }^{308}$ Principalmente, República Popular Socialista da Albânia, Alemanha Oriental também á não socialista a República Democrática Alem, República Popular da Bulgária República Soviética da China, República Democrática da Finlândia, República Popular da Hungria; República Democrática Popular do Iêmen; República Socialista Federal da Iugoslávia ,República Popular da Polônia, República Socialista da Romênia, República Socialista da Tchecoslováquia,União das Repúblicas Socialistas Soviéticas, República Democrática do Vietnã, etc.
} 
TABELA 18.

Importações, principais origens (em percentagem do total de importações)

\begin{tabular}{|l|c|c|c|c|c|c|}
\hline \multicolumn{1}{l|}{} & 1975 & 1977 & 1980 & 1982 & 1984 & 1986 \\
\hline Países da OCDE & 61 & 59,7 & 36 & 39 & 52 & 60 \\
\hline França & 5 & 2,4 & 4,2 & 9,6 & 6,4 & 6,1 \\
\hline EUA & 5,3 & 4 & 3,7 & 2 & 5,8 & 12,4 \\
\hline Itália & 2,3 & 2,6 & 4,3 & 2,7 & 0,5 & 6,3 \\
\hline Portugal & 15 & 9,3 & 4,5 & 6,1 & 8,3 & 6,1 \\
\hline Reio Unido & 7,7 & 7,3 & 2,5 & 2,4 & 4,2 & 3,9 \\
\hline RFA & 10,7 & 14,6 & 3 & 4 & 3,5 & 3,3 \\
\hline Países socialistas & - & 1,1 & 14 & 19 & 26 & 17 \\
\hline URSS & - & 0,03 & 1,9 & 4,3 & 19,4 & 12,1 \\
\hline RDA & - & - & 6,5 & 9,6 & 4,1 & 2,9 \\
\hline Países africanos & 25 & 21,1 & 21 & 18 & 15 & 16 \\
\hline RAS & 17 & 18,7 & 11 & 9,4 & 12,5 & 10,3 \\
\hline
\end{tabular}

Fonte: Mosca (2005) citada para os anos 1975 e 1977, CNP (1985), Informações Estatísticas, 1975-1984. Para os restantes anos, CNP (1987) Informações Estatísticas, 1986.

Pode-se destacar que, os parceiros comerciais continuaram os mesmos das importações e comportamento foi semelhante ao longo do período socialista. Destaca-se na parceria apenas o surgimento da Espanha como um destino importante (sobretudo de produtos de pesca) ${ }^{309}$. Os principais produtos são o mesmo do período colonial. Não obstante, é evidente que as quedas de exportações de cada produto coincidiram com o momento em que a guerra afetava a respectiva zona $^{310}$. Os cinco principais produtos representavam mais de 50 por cento do total das exportações; esta percentagem cresceu após a independência como mostra a tabela 19, que mostra os cinco principais produtos exportados.

\footnotetext{
${ }^{309}$ Ibdem.

${ }^{310}$ De acordo com Mosca (2005), são os casos, por exemplo, do açúcar, do chá e das madeiras, aspetos que é referido com maior detalhe na análise da produção. Com exceção dos derivados do petróleo (combustíveis exportados para os países vizinhos a partir da produção das refinarias moçambicanas), os restantes são bens primários sem transformação (camarão e grande parte das madeiras), ou uma pequena transformação para permitir a exportação (açúcar, algodão fibra, castanha de caju, chá e copra).
} 
TABELA 19.

\section{Exportações, principais cinco produtos (em percentagem do total)}

\begin{tabular}{|l|c|c|c|c|c|c|}
\hline \multicolumn{1}{l|}{} & 1975 & 1977 & 1980 & 1982 & 1984 & 1986 \\
\hline Total $\left(10^{3}\right.$ contos $)$ & 5050 & 49339 & 9097 & 8655 & 4060 & 3198 \\
\hline Total a preços de 1980 & $5656^{\mathrm{a}}$ & $5220^{\mathrm{a}}$ & 9097 & 7213 & 2009 & 1048 \\
\hline $1980=100$ & 62,2 & 57,4 & 100 & 79,3 & 22,1 & 11,5 \\
\hline Açúcar & 11,4 & 10,2 & 8,8 & - & 6,0 & 1,02 \\
\hline Algodão & 8,7 & & - & 7,5 & 8,4 & - \\
\hline Caju & 15,5 & 29,6 & 23,1 & 19,0 & 16,0 & 21,1 \\
\hline Camarão & - & 7,4 & 11,3 & 16,8 & 29,5 & 48,4 \\
\hline Chá & - & - & 10,3 & 11,2 & 11,3 & - \\
\hline Copra & - & 6,8 & - & - & - & 2,6 \\
\hline Madeira & 7,4 & - & - & - & - & - \\
\hline Derivados de petróleo & 7,3 & 6,6 & 22,6 & 16,4 & - & 5,0 \\
\hline Subtotal & 50,6 & 60,6 & 76,1 & 70,9 & 71,2 & 87,3 \\
\hline
\end{tabular}

Fonte: Mosca (2005) citada para os anos 1975 e 1977, CNP (1985), Informações Estatísticas, 1975-1984. Para os restantes anos, CNP (1987) Informações Estatísticas, 1986.

A tabela mostra que as quantidades de alguns produtos aumentaram (açúcar, camarão, chá e derivados do petróleo) e diminuíram os restantes constantes. Neste período apenas aumentou o volume de exportações do camarão (no mar não existia guerra!). Assim com, mostra que os principais países socialistas nas importações moçambicanas eram a RDA e a URSS. Nas relações comerciais com os países socialistas, além dos aspectos já referidos, destaca-se que funcionou o sistema barter, cujos pagamentos eram realizados com mercadoria ou serviços ${ }^{311}$. Porém, a queda de importância de Portugal é maior que o verificado nas importações.

Entretanto, dentro dos objetivos do PPI, a produção agrária teve um papel importante com a previsão da socialização total do campo em dez anos (isto é toda população viveria em aldeias comunais e trabalharia em cooperativas ou em empresas estatais). Assim sendo, na agricultura e, sobretudo abordado no tópico a seguir que faz uma caracterização da exploração agrária de Moçambique durante a implementação do Plano Prospectivo Indicativo (PPI).

\footnotetext{
311 Oppenheimer (2003) refere-se assunto relativamente às relações entre Moçambique e a RDA. Neste caso, durante algum tempo as trocas eram valorizadas com uma paridade de 1:1 entre o marco da RDA e a da RFA; este aspeto, acrescido à excessiva valorização do metical, traduzia-se em importantes desvantagens para a balança comercial moçambicana.
} 


\subsection{O setor agrário}

Este tópico faz uma caracterização da exploração agrária de Moçambique durante a implementação do Plano Prospectivo Indicativo (PPI). Entretanto, faz referencia ao desenvolvimento de algumas empresas estatais do ramo agrário em que foram concentraram elevados volumes de investimentos públicos e foi à priorização na afetação de recursos após a independência. Por o estado socialista considerando agricultura a base do desenvolvimento foi se concentrando elevados volumes de investimentos públicos e foi à priorização na afetação de recursos neste setor ${ }^{312}$. Pode-se constatar na tabela 21 a baixo, que espelha a evolução da produção comercializada agrícola, que em alguns produtos existiu uma recuperação da produção entre 1975 e 1980/1982: foram os casos do algodão, citrinos, chá, girassol e o leite. (referindo-se apenas aos principais). Os citrinos, o chá, o girassol e o leite eram produzidos quase totalmente pelas empresas estatais, o que revela que em alguns setores existiu uma recuperação da produção das E.E.

TABELA 20.

Evolução da produção comercializada agrícola (em $10^{3}$ toneladas)

\begin{tabular}{|l|c|c|c|c|c|}
\hline \multicolumn{1}{l|}{} & 1975 & 1980 & 1982 & 1984 & 1986 \\
\hline Produção total agrícola a $^{\text {a }}$ & 951 & 760 & 605 & 316 & 200 \\
\hline $1975=100$ & 100 & 79,9 & 63,6 & 44,6 & 21 \\
\hline Produção agricultura/PSG (\%) & 24,8 & 30,6 & 30,8 & 24,4 & 25 \\
\hline Cereais (milho e arroz) & 189 & 108,6 & 73,1 & 101,7 & 40,5 \\
\hline Batata + horticolas & 44 & 15,4 & 15 & 16,2 & 26,8 \\
\hline Carne & 19,8 & 18 & 14,3 & 7,3 & 0,6 \\
\hline
\end{tabular}

Considerada 12 culturas: arroz, algodão caroço, batata, castanha de caju, citrinos, chá folha, copra, feijão, girassol, milho, sisal folha.

Fonte: Mosca (2005) cita CNP (1987) Informações Estatísticas, 1986.

As razões de algumas empresas terem obtido resultados produtivos positivos, para ale dos conjuntos de setores, centrou-se na capacidade técnica e de gestão afetado a esses setores considerados estratégicos. Mas houveram decréscimos acentuados durante este todo período,

\footnotetext{
${ }^{312}$ Por exemplo, previa-se a construção no vale do Limpopo de 300000 hectares de regadio a uma média inicial de dez mil hectares novos, sensivelmente metade do existente no Chókwè e em relação aos quais existia grande dificuldade de utilização plena. Mas, também foi no campo onde a guerra reproduziu os efeitos diretos mais violentos e com maiores conseqüências sobre a economia, o que contribuiria para que a política econômica agrária se converta nuns erros importantes com efeitos sobre o decréscimo da produção (MOSCA, 2005).
} 
onde, as percas dos volumes comercializados foram imensas no primeiro qüinqüênio da década de $1980^{313}$. Somente dois produtos conseguiram manter volumes de comercialização acima dos 50 por cento relativamente aos valores de $1975^{314}$.

Porém, houve uma coincidência da queda de produção de chá com a chegada da guerra à Zambézia. A mesma situação é verdadeira para o sisal e o algodão. Na produção e comercialização do caju teve particular efeito à deslocação das populações para as aldeias comunais, que as afastou da localização das árvores, dificultando à apanha e transporte do produto, bem como o tratamento das plantas, a replantação e a ruptura da rede comercial. No caso da carne bovina, a evolução do volume de carne comercializado está diretamente associada aos anos de seca prolongada (1983 e 1984), à acentuada perda de efetivos (existiam cerca de 1,3 milhões de cabeças de gado bovino em 1973 e em meados dos anos 1980 este número era de cerca de 250 mil), à guerra e à redução ou paralisação dos serviços de veterinária, entre outras ${ }^{315}$.

\footnotetext{
${ }^{313}$ Por exemplo, Moscas (2005), mostram que, o sisal e a carne bovina e um pouco mais o chá, alcançaram menos de 10 por cento dos valores de 1975.

${ }^{314}$ Porém, o setor privado, após as reforma econômica, concentrou a produção nas culturas liberalizadas, as que proporcionavam maiores rendimentos e um retorno mais rápido dos gastos de campanha. Por outro, as cooperativas não chegaram a ter importâncias na produção agrária comercializada, exceto em hortícolas e em determinadas zonas ${ }^{315}$ Não é importante neste trabalho a análise da evolução por produto. Convém, no entanto ter em atenção, para que as razões específicas ou pontuais de cada produto não façam esquecer o conjunto da evolução econômica e social do país e dos efeitos combinados dos múltiplos fatores que foram apresentados e outros que serão ainda abordados. Só a compreensão global da política, do modelo e das respectivas medidas e aplicação, bem como das conjunturas externas e da evolução dos conflitos, por outro lado, e as formas de resistências e adaptação dos agentes econômicos, por outro, pode evitar a análise compartimentada e reducionista dos comportamentos setoriais e por produto. Para a evolução da produção setorial poderiam ter contribuído; segundo Wuyts (1978), a especialização produtiva, onde se manteve o subsidio do setor estatal ao setor privado. As empresas estatais reproduziram a estrutura produtiva (combinada de culturas) e as tecnologias (neste caso com maior capitalização, mais maquinas e produtos químicos), bem como as formas e métodos de relacionamento com a população, sobretudo no que respeita á contratação de mão de obra.
} 
TABEL 21.

Evolução da produção comercializada agrícolas por setor social (em $10^{3}$ toneladas).

\begin{tabular}{|c|c|c|c|c|}
\hline & 1980 & 1982 & 1984 & 1986 \\
\hline \multicolumn{5}{|l|}{ Algodão caroço } \\
\hline Setor estatal & 15,1 & 25 & 8,5 & 4,4 \\
\hline Setor cooperativo & 0,6 & 0,3 & 0,3 & 0,1 \\
\hline Setor privado & 6,6 & 6 & 2,3 & 0,8 \\
\hline Setor familiar & 42,6 & 29,1 & 8,6 & 5,5 \\
\hline \multicolumn{5}{|l|}{ Arroz } \\
\hline Setor estatal & 33 & 37,7 & 15,1 & 12,7 \\
\hline Setor cooperativo & 1,3 & 1 & 0,3 & 0,1 \\
\hline Setor privado & 2,0 & 0,2 & 0,4 & 0,3 \\
\hline Setor familiar & 7,3 & 2,7 & 3,2 & 5,9 \\
\hline \multicolumn{5}{|l|}{ Castanha de caju } \\
\hline Setor familiar & 87,6 & 57 & 25,3 & 40 \\
\hline \multicolumn{5}{|l|}{ Citrinos } \\
\hline Setor estatal & 37,3 & 38,1 & 24,5 & 20,2 \\
\hline \multicolumn{5}{|l|}{ Folha do chá } \\
\hline Setor estatal & 79,4 & 95,1 & 58,6 & 6,4 \\
\hline Setor privado & 10,8 & 14,6 & 1,2 & 0 \\
\hline \multicolumn{5}{|l|}{ Copra } \\
\hline Setor estatal & 15 & 10,8 & 11 & 9,2 \\
\hline Setor privado & 11,8 & 9,9 & 9,9 & 6,6 \\
\hline Setor familiar & 10,3 & 15,9 & 3,9 & 12,8 \\
\hline \multicolumn{5}{|l|}{ Girassol } \\
\hline Setor estatal & 1,6 & 0,9 & 0,4 & 0,1 \\
\hline Setor cooperativo & 0,6 & 0,2 & 0,1 & - \\
\hline Setor privado & 1,7 & 0,3 & 0,4 & 0,1 \\
\hline Setor familiar & 7,9 & 9,4 & 4,1 & 0,8 \\
\hline \multicolumn{5}{|l|}{ Milho } \\
\hline Setor estatal & 30,8 & 44,5 & 46,1 & 7,8 \\
\hline Setor cooperativo & 1,9 & 1,5 & 1 & 0,4 \\
\hline Setor privado & 7,3 & 3,8 & 3,7 & 1,6 \\
\hline Setor familiar & 25 & 36,5 & 31,7 & 11,7 \\
\hline \multicolumn{5}{|l|}{ Sisal } \\
\hline Setor estatal & 95,4 & 45,7 & 55,5 & nd \\
\hline Setor privado & 202,6 & 94,2 & 81 & nd \\
\hline
\end{tabular}




\begin{tabular}{|l|c|c|c|c|}
\hline \multicolumn{1}{|c|}{ Hortícolas } & 4,7 & 4,5 & 10,2 & 5,6 \\
Setor estatal & - & - & 1 & 0,9 \\
Setor cooperativo & 2 & 3,2 & 8,8 & 17,2 \\
Setor privado & - & - & - & 0,3 \\
Setor familiar & - & - & - & \\
\hline
\end{tabular}

Fonte: Mosca (2005) cita CNP (1987) Informações Estatísticas, 1986.

$\mathrm{Na}$ situação da crise moçambicana, não é possível ser-se conclusivo sobre o comportamento e o ajustamento dos camponeses ${ }^{316}$. No caso de Moçambique é consensual afirmar que houve uma perda do poder aquisitivo dos agricultores, uma deterioração dos termos de troca e uma queda dos preços reais agrícolas, seja comparativamente com a inflação como relativamente à evolução de bens não agrícolas, tanto a nível setorial como nas análises como nas por produto $^{317}$. O que seguinte revela a deterioração dos termos de troca dos camponeses entre 1979 e 1980 com melhoria até 1986. Embora não conste a tabela 22, considerando o período em análise, a mesma fonte revela que os termos de troca voltaram a decair.

TABELA 22.

Relação de troca dos camponeses $(1986=100)$

\begin{tabular}{|c|c|c|c|c|}
\hline 1976 & 1980 & 1983 & 1985 & 1986 \\
\hline 88 & 69 & 74 & 97 & 100 \\
\hline
\end{tabular}

Fonte: Mosca (2005) citando, Abrahamisso e Nilsson (1994).

Entretanto, ao analisarem a evolução dos preços reais (preços normais deflacionados com o IPC) e os resultados observados na tabela são seguintes; existência de uma evolução positiva dos preços reais, tanto aos produtores como ao consumidor, entre 1976 e 1980, e há uma

\footnotetext{
316 Se bem que seja aceitável o argumento de que os pequenos produtores procuraram garantir a auto-suficiência alimentar com complementaridade da produção de bens de rendimento. A questão dos preços agrícolas é, sem duvida, um dos elementos mais controversos. Existiam vários critérios, todos eles individualmente insuficientes, para refletirem a evolução do nível da qualidade de vida dos produtores e o meio rural. As variáveis são muitas, com pesos diferentes segundo o tipo de produtores, os sistemas de produção, as tecnologias, etc. Mas, os critérios mais utilizados nas análises são os preços de fronteira, os preços de mercado internacional, os custos de produção, os preços de "equilíbrio" do mercado interno, os termos de troca entre meio rural e a cidade ou entre os bens agrícolas e os não agrícolas, etc. Os estudos mais completos procuram indicadores - sínteses entre os termos de troca ponderando com a inflação e com os custos de produção (MOSCA, 2005).

${ }^{317}$ No entanto, dos estudos a que se teve acesso nenhum possui metodologias que permitam concluir sem quaisquer reservas sobre a evolução dos termos de troca entre campo e a cidade, entre o setor agrícola e o conjunto da economia ou ainda entre os camponeses e o restante da sociedade.
} 
inversão desta tendência, principalmente depois de 1984; as diferenças entre preços ao consumidor (ou à porta da fábrica) são geralmente elevadas, destacando-se o algodão; há uma grande instabilidade nos preços agrícolas, tanto aos produtores como aos consumidores (ou à porta da fábrica), o que revela, por exemplo, a ausência de mecanismos reguladores, as dificuldades de ajustamento das políticas públicas, etc. ${ }^{318}$

\subsection{O setor industrial}

Este tópico procura caracterizar o setor industrial durante a implementação do Plano Prospectivo Indicativo (PPI). Num período em que o setor industrial foi objeto de protecionismo. Não eram autorizadas importações de bens correntes com a produção nacional e eram proibidas exportações de matérias primas antes que as fábricas estivessem abastecidas ${ }^{319}$. Porém, as observações mais relevantes apresentadas na evolução da produção e o peso relativo dos principais ramos da indústria transformadora são os seguintes; Foram as indústrias, associadas com a produção agrícola (majoritariamente de exportação), as que sofreram as principais quedas produtivas $^{320}$ em consequiência da baixa produção das matérias primas, com particular destaque para depois do ano 1982. São os casos, por exemplo, do açúcar, do caju e dos óleos e sabões. A produção de energia e explicada pela interrupção da exportação da produção da barragem de Cabora Bassa para a RAS por sabotagem das linhas de alta tensão. Pode-se constatar na tabela 24, que faz menção a produção industrial, que a estrutura do parque industrial se manteve sensivelmente a mesma herdada do período colônia.

\footnotetext{
${ }^{318}$ Ressalva-se que o estudo foi realizado considerando os preços oficiais, o que corresponde muito parcial à realidade (MINISTÉRIO DA AGRICULTURA E DA FAO, 1987)

${ }^{319}$ Um dos exemplos marcantes foi; a exportação de castanha de caju só era permitida após o abastecimento das fábricas; em consequiência da baixa de produção agrícola, o circuito Moçambique - Índia foi interrompida, independentemente dos preços de exportação e dos pagos à porta da fábrica. Assim como, a indústria de produção de alfaias e de instrumentos de trabalho para a agricultura (empresas estatal Agro Alfa) produzia bens de qualidade constatada pelos utilizadores por baixa durabilidade e resistência dos materiais; as importações destes equipamentos eram restringidas. $O$ protecionismo à indústria prejudicava a agricultura: os preços internos eram geralmente mais elevados e a qualidade e durabilidade eram inferiores (MOSCA, 2005).

${ }^{320}$ Não obstante o fator referido se pode considerar que a baixa de produção industrial se deve principalmente aos seguintes fatores: baixa de produção agrícola local e a conseqüente redução do abastecimento às fábricas; redução da importação de matérias primas e de peças sobressalentes por escassez de divisas.
} 
TABELA 23.

Produção industrial (a preços de 1980, $10^{3}$ contos)

\begin{tabular}{|c|c|c|c|c|c|c|c|c|c|}
\hline & 1975 & $\begin{array}{l}\text { Percent } \\
\text { agem }\end{array}$ & 1980 & $\begin{array}{l}\text { Percent } \\
\text { agem }\end{array}$ & 1982 & 1984 & 1986 & $\begin{array}{c}\text { Percentag } \\
\text { em }\end{array}$ & $\begin{array}{c}1986 / 1990 \\
(\%)\end{array}$ \\
\hline Açúcar & 2945 & 10,5 & 2185 & 6,8 & 1620,2 & 506,4 & 217,2 & 1,5 & 9,9 \\
\hline Algodão & 1287 & 4,6 & 1095,8 & 3,4 & 571 & 750,1 & 520,8 & 3,5 & 49,2 \\
\hline Bebidas & 3105 & 11,1 & 2503 & 7,7 & 1925,4 & 1574,5 & 1204,5 & 8,1 & 48,1 \\
\hline Caju & - & - & 1758 & 5,4 & 1355,9 & 307,4 & 418,6 & 2,8 & 23,8 \\
\hline Cimento & 339 & 1,2 & 334 & 1 & 399,3 & 146,1 & 105,6 & 0,7 & 31,7 \\
\hline $\begin{array}{l}\text { Construções } \\
\text { mecânicas }\end{array}$ & 700 & 2,5 & 205,1 & 0,6 & 127,4 & 379,8 & 323,7 & 2,2 & 158,1 \\
\hline Energia elétrica & 646 & 2,3 & 1045 & 3,2 & 543 & 633 & 33,7 & 0,2 & 3,2 \\
\hline Farinha & 869 & 3,1 & 1043 & 3,2 & 1045,7 & 1376,2 & 1219 & 8,2 & 116,9 \\
\hline alimentares & 1123 & 4 & 1705 & 5,3 & 1656 & 811,4 & 515 & 3,5 & 30,2 \\
\hline Óleos e sabões & 3606,7 & 12,9 & 6214 & 19,2 & 4654,6 & 919,3 & - & - & - \\
\hline $\begin{array}{l}\text { Derivados de } \\
\text { petróleo }\end{array}$ & 1831 & 6,5 & 811 & 2,5 & 811,1 & 549,2 & 788 & 5,3 & 97,2 \\
\hline Tabaco & 1500 & 5,4 & 1194 & 3,7 & 1488 & 1849,8 & 1110 & 7,5 & 93 \\
\hline Têxtil & - & - & 1528 & 4,7 & 1401,4 & 1808,9 & 1040,2 & 7,4 & 68,1 \\
\hline $\begin{array}{l}\text { Vestuários } \\
\text { Sutotal s/caju e } \\
\text { vestuários }\end{array}$ & 17956 & 64,1 & 18335 & 56,6 & 14842 & 9496 & 6038 & 40,8 & 32,9 \\
\hline $1980=100$ & 96 & - & 100 & - & 80,9 & 51,8 & 32,9 & - & - \\
\hline $\begin{array}{l}\text { Produção bruta } \\
\text { industrial }\end{array}$ & 28029,9 & 100 & 32369,8 & 100 & 20011,8 & 19270,1 & 14791,6 & 100 & 45,7 \\
\hline $1980=100$ & 86,6 & - & 100 & - & 89,6 & 59,5 & 457 & - & - \\
\hline
\end{tabular}

Fonte: Mosca (2005) citada CNP (1987). Informações Estatísticas, 1986.

Após a independência, foram poucos os investimentos realizados em novas indústrias ou na modernização do parque existente. $\mathrm{O}$ conjunto dos setores produzia a menos de 50 por cento da capacidade instalada e a competitividade no mercado não constituía preocupação do período: os mecanismos protecionistas e o plano, os salários e os preços controlados, a política fiscal e cambial, o crédito estatal e os subsídios, etc., permitiram o funcionamento das empresas estatais independentemente da rentabilidade financeira e econômica. Excetuando alguns investimentos, como por exemplo, os relacionados com a indústria madeireira com a cooperação sueca (na província de Manica). Também neste caso esteve presente a mesma concepção de desenvolvimento: tecnologia avançada não dominada localmente, como símbolo do socialismo e do progresso; grande dimensão; constituição de empresa monopolista; suporte financeiro e assistência técnica externa, isto é, excessivas expectativas sobre a cooperação internacional. 
Também neste caso estão presentes a não sustentabilidade e o aprofundamento da dependência.

A redução da produção industrial, associada com as matérias primas nacionais, foi mais acentuada a partir de meados da década de 1980, em conseqüência dos efeitos combinados da guerra e da crise econômica. Registram comportamentos positivos das indústrias dependentes de matérias primas com grande contributo da ajuda internacional (caso das farinhas alimentares devido aos donativos de trigo), e daquelas cujas necessidades de matérias primas representavam percentagens relativamente baixas da produção nacional (caso dos têxteis).

De um modo geral, previa-se o desenvolvimento de uma indústria pesada como condição para a independência econômica. Planificando-se o surgimento de uma desenvolvida indústria de ferro e do aço, etc. Assim sendo, o PPI para a área econômica, direcionou a indústria extrativa a um lugar de destaque, por exemplo, o carvão no vale do rio Zambeze (com centro em Moatize) e algumas pedras preciosas na Zambézia representavam grande parte da exploração mineira. Somente o carvão representava cerca de 60 por cento do total do valor da produção em 1975;

TABELA 24.

Produção industrial de Carvão e Pesca (a preços de 1980, 10³ contos)

\begin{tabular}{|l|c|c|c|c|c|}
\hline \multicolumn{1}{l|}{} & 1975 & 1980 & 1982 & 1984 & 1986 \\
\hline Recursos minerais (total) & 689 & 356 & 376 & 216 & 129 \\
\hline $1980=100$ & 1,94 & 100 & 106 & 60,7 & 36,2 \\
\hline Carvão & 408 & 153 & 152 & 37 & 44 \\
\hline Pesca & 1013 & 1335 & 1315 & 1360 & 1528 \\
\hline
\end{tabular}

Fonte: Mosca (2005) citada CNP (1987). Informações Estatísticas, 1986.

A produção mineira em 1986 era de cerca de 20 por cento da verificada em 1975 e a de carvão mão ultrapassava os 11 por cento ${ }^{321}$. Como para a exploração desse e outros recursos, Moçambique possuía grandes expectativas de aquisição de capital para a sua implantação com base na cooperação "internacionalista" com os países socialistas ${ }^{322}$. Os apoios iniciais na

\footnotetext{
${ }^{321}$ A exploração mineira foi interrompida com a guerra, no caso da Zambézia, com ataques diretos às unidades produtivas, tendo a RENAMO raptado cooperantes. Relativamente à exploração de carvão por impossibilidade de escoamento através da linha féria Moatize - Beira durante largos períodos. Existiram ainda tentativas de escoamento por meio de carros, mas os custos eram insuportáveis e as estradas eram também freqüentemente atacadas (MOSCA, 2005).

322 Nota-se que a independência de Moçambique acontece num período de importantes vitórias das forças revolucionárias e dos movimentos de libertação (a vitoria do Vietname, a guerra da Argélia, as independências africanas, os acontecimentos estudantis na Europa, a afirmação da social-democracia nos países nórdicos
} 
indústria foram na formação das inúmeras comissões mistas de cooperação ${ }^{323}$, que planificavam as relações econômicas através de projetos de desenvolvimento alongo prazo, bem como os intercâmbios comerciais de curto prazo $^{324}$. Os acordos de cooperação eram geralmente muito burocrática isto devido a seguintes aspetos: as comissões intergovernamentais acordavam, por exemplo, a concessão de um crédito para a aquisição de uma determinada quantidade de equipamentos. Os governos informavam as empresas de comércio externo dos respectivos países. Estas contratavam as empresas produtoras do equipamento que incluíam a encomenda nos respectivos planos de produção para os anos seguintes. Quando produzido, o equipamento era endereçado à empresa de comercio externo que procedia à exportação. No país receptor, a empresa importadora fornecia (isto é, entregava) ${ }^{325}$.

A exploração teve a cooperação de países socialistas, sobretudo para o caso do carvão a RDA, e União Soviética ${ }^{\mathbf{3 2 6}}$. O carvão era um importante setor no quadro geral da cooperação entre Moçambique e a RDA e para um possível equilíbrio da balança comercial entre os dois países. A pesca, sobretudo de mariscos, cresceu de forma consistente. As licenças de exploração estavam integradas em acordos de cooperação, principalmente com a URSS, Espanha e Japão. A pesca realizada no alto mar não vinha aos portos moçambicanos, nem o país possuía capacidade de fiscalização das quantidades pescadas e exportadas. Paralelamente, desenvolveu-se a pesca

considerados então como uma possível terceira via, etc); os países socialistas atravessavam momento de um aparente esplendor econômico ( HODGES, 2002).

${ }^{323}$ As comissões mistas eram grupos de trabalho bilateral, compostas por altos responsáveis e por equipes técnicas que planificavam e decidiam sobre a cooperação entre os países. As comissões reuniam-se periodicamente para análise da evolução da cooperação, bem como para à resolução dos problemas e dificuldades. As comissões tinham vários níveis: governamentais e ministeriais, estas mais de caráter técnico e comercial, que aplicavam as decisões estabelecidas entre os governos aos mais altos nível (presidente da república e primeiro-ministro) (MOSCA, 1999).

${ }^{324}$ Essa cooperação econômica concentrava-se na agricultura, pescas e na indústria extrativa. $O$ fornecimento de equipamentos e de assistência técnica consistia as principais de colaboração; posteriormente surgem projetos comuns na agricultura e na indústria extrativa, sobretudo para a produção de bens exportáveis (algodão, trigo, carvão, peixe e mariscos).

$325 \mathrm{O}$ equipamento a empresa de distribuição interna de máquinas que finalmente endereçava à empresa "contemplada" pelo plano. E refere ainda: "A este labirinto burocrático acrescentava-se em muitos casos, o equipamento chegava ao utilizador sem que os técnicos e gestores tivessem participando em qualquer discussão sobre preço, características técnica, condições de assistência pós venda, importação de peças sobressalentes, etc.". Embora as fases de negociação intergovernamental se traduzissem em condições através de relações comerciais entre empresas nem sempre foram exemplares e não existiam mecanismos de controlo ou se existissem eram muito débil (MOSCA, 2005).

${ }^{326}$ Não obstante, nesta e outras áreas ajuda da URSS chegou a representar cerca de 30 por cento a Moçambique. Tem particular importância o fornecimento de petróleo por parte da União Soviética nos momentos da subida dos preços internacionais, sem que Moçambique não implicasse, necessariamente, intromissões e condicionamentos nas políticas internas ou em contrapartidas econômicas ou militares (MOSCA, 2005). 
artesanal ao longo da costa, sobretudo ao longo dos principais centros urbanos ${ }^{327}$.

\subsection{O setor do transporte}

Este tópico caracterizar a situação do setor dos transportes durante a implantação do Plano Prospectivo Indicativo (PPI). Porém, a evolução política de transporte em Moçambique, o seu funcionamento desde principio, foi marcado por vaias dificuldades como; a existência de poucos funcionários e técnicos dos ministérios que acreditaram na exeqüibilidade do plano aos ritmos definidos, muito embora, por outro lado, o PPI tivesse reforçada a idéia de um projeto de desenvolvimento em longo prazo $^{328}$. Nos transportes, particularmente os caminhos de ferro e a exploração dos portos, após a independência, atravessaram dificuldades provocadas pela conjugação de um conjunto de fatores. Internamente, as mudanças da pós-independência, afetaram a eficiência e eficácia do setor e os investimentos para a modernização dos portos e das vias não acompanharam a evolução do setor a nível internacional e regional ${ }^{329}$. A eletrificação das vias, a contenção dos transportes marítimos e dos portos, e a adaptação dos caminhos de ferro foram inadequadas, fazendo perder a competitividade derivada da maioria proximidade (com outros portos da região) dos mercados de origem e destino do tráfego de mercadorias do hinterland ${ }^{330}$.

Esta limitação deveu-se em parte as ações de guerilha de Resistencia nacional moçambicana (RENAMO) que estavam coordenadas com a agressividade econômica e as ações de marketing dos caminhos de ferro sul-africanos que pretendiam (e conseguiram), desviar grande parte do tráfego dos países da África Austral para o sistema de transporte da RAS. As

\footnotetext{
${ }^{327}$ O mesmo autor fere que, o Estado criou uma empresa de pesca estatal, a EMOPESCA (Empresa Moçambicana de Pesca), que tinha como função a emplementação da política de pesca e a exploração da atividade: foi ainda criada uma Secretaria de Estado para o setor.

${ }^{328}$ Segundo Adam (1996), o PPI recuperou muito dos projetos portugueses, com as seguintes diferenças: A cerca do papel do estado e das empresas estatais; Os objetivos coloniais eram mais limitados; Portugal possuía recursos e os apoios internacionais e regionais para realização dos projetos; Os projetos eram dirigidos aos colonos, sendo os moçambicanos previstos apenas como mão de obra.

${ }^{329}$ Ver. SAÚTE, Nelson. Cronica de uma Integração Inperfeita: o caso da privatização da gestão dos portos e caminhos de ferro em Moçambique. 2010.

${ }^{330}$ Os ataques sistemáticos da RENAMO às vias férreas tinham como objetivo estrangular a economia e provocar instabilidade social nas principais cidades, considerando a importância deste setor no emprego. Estes aspetos, associado às mudanças estruturais e organizativas da pós-independência, provocavam demoras, riscos elevados e inseguranças que fizeram com que os clientes preferissem as vias sul-africanas (MOSCA, 1999).
} 
políticas de subsídio e de tarifas, a ruptura de compromissos com os CFM e outras práticas, acrescidos aos investimentos de modernização realizados neste país, são parte integrante do conflito regional. Por outro lado, a concretização e modernização do sistema de transporte e de comunicação criaram monopólio sul-africano de operadores de agenciamento e contratação de tráfego ao nível da África Austral, que influenciavam os clientes a utilizar as vias que lhes interessavam $^{331}$.

O decrescimento rápido do tráfego de mercadorias entre 1975 e 1977 é seguindo de algumas estabilizações nos níveis dos 7-8 milhões de toneladas; a partir de 1982/1983, a quando ao agravamento da guerra e do profundamente da crise econômica ${ }^{332}$. Os transportes e os portos moçambicanos, entretanto, pertenciam ao Estado, e eram geridas pela Direção Nacional dos Portos e dos Caminhos de ferro (DNPCF), que desempenha simultaneamente as funções de Estado e empresariais para o setor ${ }^{333}$. Os transportes ferroviários de passageiros tiveram um comportamento distinto até 1982/1983; o número aumentou até esse período e decresceu posteriormente ${ }^{334}$. Assim sendo, a tabela 26 a baixo pode-se observar o transporte de carga rodoviário refletiu um decréscimo entre 1975 e 1977, seguido de uma importante recuperação até 1981/1982 e uma redução rápida até ao fim do período em análise ${ }^{335}$.

\footnotetext{
${ }^{331}$ Não obstante a SADCC procurou realizar investimentos para modernização das linhas férias moçambicanos persistiam inúmeras dificuldades de segurança, organização, eficiência do sistema e de comunicação entre Moçambique e o Zimbábue. Os esforços intergovernamentais eram esbarrados pelos interesses das agências que funcionavam em regime de monopólio e com acordos com os principais utilizadores (clientes) da África Austral. "apenas um pequeno volume do tráfego voltou a ser escoado através de Maputo, desde que a fronteira foi aberta em 1980. Maputo voltou a escoar uma parte das exportações a granel, nomeadamente açúcar, aço e ligas de ferro. As mercadorias destinadas aos portos de Moçambique eram as do governo, a ajuda alimentar e de outros bens relacionados com a cooperação e as que, por razões políticas ou outras, os clientes rejeitavam no sistema de transporte sul-africano" (MACKINTOSH, 1986).

${ }^{332} \mathrm{O}$ trafico interno decaiu, sobretudo a partir de 1982, assim sendo, as mercadorias nacionais representavam cerca de 16 por cento do total do tráfego ferroviário em 1975 e 22 por cento em 1986 (MOSCA, 2005).

${ }^{333}$ Grande parte dos serviços portuários (estiva, alfândegas, agenciamento, etc.,) foi intervencionada e integrada na DNPCF ou serviços especializados.

${ }^{334}$ Podem existir várias razões que justificam esse comportamento durante os primeiro anos; aumento do poder aquisitivo devido aos aumentos salariais verificados no período de transição e a manutenção das tarifas; os sentimentos de liberdade e a eliminação das dificuldades de mobilidade da população existentes no período anterior. O mesmo fenômeno se verificou no volume de transporte de passageiros rodoviários (MOSCA, 2005).

${ }^{335} \mathrm{O}$ fenômeno das intervenções públicas, das comissões administrativas e das empresas estatais aconteceu também nos transportes rodoviários. Foram criadas as empresas ROMOS, ROMOC e ROMAN, que congregavam todas as empresas de autocarros intervencionadas. Neste setor, persistiram algumas empresas privadas, como por exemplo, os Oliveiras de Xaí-Xai (MOSCA, 1999).
} 
TABELA 25.

Transporte de carga e passageiros

\begin{tabular}{|l|c|c|c|c|c|c|}
\hline \multicolumn{1}{c|}{ Transportes } & 1975 & 1977 & 1980 & 1982 & 1984 & 1986 \\
\hline Ferroviário de carga $\left(10^{3}\right.$ ton/km) & 13413,6 & 8125,7 & 7546,9 & 6742,2 & 3698,6 & 2949,3 \\
$17980=100$ & 77,7 & 107,7 & 100 & 89,4 & 49 & 39,1 \\
Nacional & 2197,5 & 2197,5 & 1992,6 & $2,071,1$ & $1,243,5$ & 649,1 \\
Internacional & 11216,1 & 5928,6 & 5554,3 & 4671,1 & 2455,1 & 2300,2 \\
$1980=100$ & 201,9 & 106,8 & 100 & 84,1 & 44,2 & 41,4 \\
Ferroviário de passageiro & 335,8 & 414,3 & 562,6 & 457,6 & 284,1 & 263,4 \\
$\left(10^{3}\right.$ ton/km) & 30395 & 18500 & 51195 & 46855 & 32789 & 27914 \\
Rodoviário de carga (103ton/km) & 78,5 & 76,7 & 106,3 & 100,9 & 88,4 & 70 \\
Rodoviário de passageiro $\left(10^{\mathrm{c}} \mathrm{p}\right)$ & & & & & & \\
\hline
\end{tabular}

Fonte: Mosca (2005) cita, para os anos de 1975 e 1977, CNP (1985), Informações Estatísticas, 1975-1984. Para os restantes anos, CNP (1987) Informações Estatísticas, 1986.

Nas cidades, os serviços de transporte urbanos que pertenciam às administrações coloniais no período colonial transitaram igualmente para o poder municipal após a independência; os serviços começaram a se designar de TPU (transportes públicos urbanos). Foram realizados nos primeiros anos investimentos em autocarros. Em consequiência da má utilização e deficiente manutenção e assistência técnica, a frota de autocarros públicos urbanos entrou em colapso. As reformas iniciadas em 1982/1983 atingiram também o setor. Os caminhos de ferro foram constituídos em empresas (Sul, Centro, Norte) com maior autonomia financeira e gestão empresarial; o setor privado começou a operar informalmente nas cidades com os famosos "chapas $100^{336}$ ". Os produtores agrícolas e comerciantes privados começaram a ter acesso à aquisição da carinha e camiões que chegava a Moçambique no âmbito de diversos programas de cooperação e ajuda ${ }^{337}$.

Entretanto, em pouco tempo (menos de três anos, entre 1980 e 1983) um conjunto de fatores tornou evidente a impossibilidade de concretização dos objetivos do $\operatorname{PPI}^{338}$. Continuidade

\footnotetext{
${ }^{336}$ Inicialmente se pagava 100 meticais independentemente do percurso. Os "chapas" eram, na maioria, carinhas de caixa aberta sem quaisquer condições de transporte de passageiros, geralmente muito velhas, e transportavam pessoas apinhadas e penduradas sem segurança.

337 Com a criação da SADCC foI iniciado, a partir de meados da década de 1980, importantes projetos de reabilitação das vias e dos portos. Porém, com a guerra, os resultados não foram suficientes para inverter a situação existente (WUYTS, 1989).

338 A partir de princípios dos anos 1980, surgem os primeiros sinais de uma grave crise econômica e é particularmente em 1983 que começam a ser tomadas medidas para a sua redução culminando com a adoção, em princípios de 1987, do Programa de Reabilitação Econômica (SERRA, 2000).
} 
e o agravamento da crise devem-se, em síntese, a generalização da guerra após independência, tendo a RENAMO tomado a iniciativa militar e aumentando rapidamente a capacidade de luta. Esse aumento da capacidade em parte se deve a passagem do centro de apoio da RENAMO da Rodésia para África do Sul com a independência do Zimbábue ${ }^{339}$, o que possibilitou a ocupação de alguns distritos de capitais importantes (como por exemplo, no vale do Zambeze), sem muita resistência do exército do governo aproximadamente por dois anos ${ }^{340}$.

A guerra generaliza-se em quase todo o país, alcançando zonas de grande importância econômica a sul do save (o vale do Limpopo e as vias de acesso a Maputo começaram a ser persistentemente ‘ atacadas). Paralelamente, o exercito moçambicano se revela incapaz e com uma perda de iniciativa e descrença no seio dos comandos militares ${ }^{341}$. Essa situação levou à presença do exército do Zimbabué no território moçambicano com objetivo de proteger a estrada de ferro e de asfalto que ligam acidade da Beira-Moçambique à Mutare- zimbabw. O contributo do exercito zimbabweano, foram na participação de operações de grande envergadura, como por exemplo, na recuperação do vale do Zambeze, principalmente as instalações das então Sena Sugar States (Marromeu, Luabo, etc.) e no ataque ao quartel-general da RENAMO na Gorongosa. O vizinho Malawi que possuía relações com a FRELIMO e a RENAMO contribuiu também com força militar para a proteção do corredor de transporte Nacala-Malawi ${ }^{342}$.

Apesar das contribuições dos países amigos, a destruição de infra-estruturas assumiu proporções enormes, em que alguns dados apresentados são: cerca de 20 por cento das barragens, 14 por cento de pequenos sistemas de irrigação, 23 por cento das lojas, 11 por cento dos correios, 22 por cento das administrações distritais, 40 por cento das administrações municipais; etc. foram destruídas pela guerra ${ }^{343}$. Entre 1980 e 1990, o PIB decresceu em mais de 30 por cento; o

\footnotetext{
${ }^{339}$ Existiam claros indícios das intenções da RAS e da RENAMO em dividir o país pelo centro (pelo rio Zambeze) e estabelecer um governo paralelo (SAUL,1983).

${ }^{340}$ Ver Hanlon (1990).

${ }^{341}$ Recorda-se a deslocação de Samora Machel à província da Zambézia após a tomada de grande parte do território pela RENAMO; nessa deslocação, o presidente destitui o comando militar provincial, nomeia novos chefes militares e recruta para o exercito alguns antigos combatentes da luta de libertação nacional que ocupavam cargos no Estado e nas empresas estatais. É nomeado como comandante provincial um general que tenha sido o comandante das forças da FRELIMO no interior do Zimbábue durante a luta de libertação deste país (FAUVET; MOSSE, 2004).

${ }^{342}$ É conhecido o apoio do Malawi como local de transito e como base de logística da RENAMO. Este fato levou à deslocação de Samora Machel a conversações com então presidente malawiano e, no regresso, afirmou ter mandado “apontar os mísseis para o Malawi”, Fauvete Mossa (2004). Cahen (1987) refere-se também ao envolvimento do Malawi no apoio À Renamo, sobretudo a partir de meados da década dos anos 1980. Este autor afirma ainda que, este apoio foi importante para a ofensiva da RENAMO nas províncias de Tete e da Zambézia. Refere-se ainda às tentativas de aproximação entre o Malawi e Maputo.

${ }^{343}$ Segundo Mosca (2005).
} 
crescimento econômico anual, no mesmo período, chegou a ser de 20 por cento com mais de cinco anos de crescimento negativo. Associado as despesas militares que chegaram a representar entre 12 e 18 por cento do PIB e entre 18 por cento 26 por cento das despesas públicas durante os anos 1980. A dívida externa aumentou em quase 500 por cento entre 1984 e 1992 . Entre 1985 e 1993 (período mais violento do conflito), 63 por cento do investimento direto externo foi cancelado ou não se iniciou ${ }^{344}$.

Entretanto, o efetivo de cerca de um milhão e trezentos mil cabeça de gado bovino existente em 1980 passou para aproximadamente 250000 em 1992, atribuindo-se que uma elevada percentagem desta evolução tenha sido por efeitos diretos e indiretos da guerra. Perto de 27 por cento de locomotivas dos caminhos em 1989 estavam destruídas ou danificadas. Em 1991, 57,8 por cento das escolas primárias estavam destruídas ou encerradas. A destruição de centro de saúde e o assassinato de técnico de saúde eram alvos importantes para RENAMO ${ }^{345}$.

A ajuda externa não chega e Moçambique isola-se, a pobreza aumentou o número de deslocados de guerra e a concentração da população em redor dos centros urbanos subiu rapidamente $^{346}$. A escassez de recursos se fez sentir também no turismo que, devido à guerra entrou em ruptura após a independência, onde a caça nas coutadas e o turismo cinegético relacionada com a fauna bravia paralisaram em consequiência da guerra na província de Sofala, onde se encontrava esta atividade. O turismo de praia dos rodesianos e sul-africano pararam devido à evolução política regional. Apenas restou um turismo interno de praia, residual, sem expressão, de uma minúscula elite nacional ${ }^{347}$. Porém, os operadores turísticos abandonaram igualmente o país; nestes casos, não existiu a preocupação de manter as infra-estruturas operacionais: os parques de caça foram praticamente abandonados ou destruídos pela guerra; o safári de caça deixou de existir e as coutadas e infra-estruturas foram igualmente abandonadas ou destruídas; as casas de praia foram nacionalizadas e ocupadas pela população alugadas pela

\footnotetext{
344 Bruck (2000).

${ }^{345}$ Cliff e Noormahomed (1988) referem em particular aos efeitos da guerra, que teve inicio em 1976, fez ressentir o agravamento da crise econômica em vários setores, sobretudo nos seguintes aspetos: Redução do orçamento público, com conseqüência sobre a manutenção e recuperação das infra-estruturas e sobre a logística; A rápida urbanização agravou a capacidade de oferta dos serviços com efeitos sobre a qualidade e as acessibilidades; A guerra interrompeu o progresso do país.

${ }^{346}$ Moscca (2002) refere que, não obstante a gravidade revelada por estes valores, as conseqüência psicológicas, os traumas pessoais, as mudanças, mas relações interpessoais e algumas manipulações sobre as diferenças étnicas deixarão seqüelas que poderão constituir dificuldades para os períodos seguintes; a crise, o conflito, a pobreza, etc., elevaram os conflitos às suas formas mais violentas, seja sob a forma de guerra seja ao nível social e político.

${ }^{347}$ Este turismo incrementou-se após meados dos anos 1980 e começou a surgir a reabilitação e construção de casa de praia, sobretudo na Ponta de Ouro, Bilene e na costa de Inhambane.
} 
APIE. Alguns hotéis nas cidades mantiveram-se em funcionamento e sobreviveram, sobretudo devido as deslocação em serviços dos funcionários públicos e das empresas estatais, de cooperantes e de agentes relacionados com a cooperação internacional ${ }^{348}$.

Considerando insustentável o modelo de desenvolvimento, principalmente devido á escassez de recursos externos e à limitada cooperação, porém, mesmo sem a guerra, os custos da dívida externa constituiriam uma restrição fundamental ${ }^{349}$. Conclui que o modelo era insustentável em conseqüência das suas contradições ${ }^{350}$. A cooperação e as relações externas de Moçambique, como em qualquer economia, desempenharam um papel importante. Também neste aspecto esteve presente a radicalização ideológica. A combinação dialética entre conflito e políticas econômicas, a luta interna e agressividade externa em contexto de Guerra Fria estão na base da instabilidade econômica que se reflete em ciclos de crescimento relativamente rápidos e períodos de crises profundas cujas consequiências os números não traduzem.

Entretanto, uma combinação de fatores internos e externos inviabilizou o desenvolvimento do Plano, entre elas salienta excesso de confiança dos apoios dos países socialistas, dos africanos (com exceções) e dos nórdicos, durante a luta de libertação, influenciaram as relações pós-independência. Porém, a dependência em relação ao apoio financeiro e da mão de obra especializada estrangeira, sobretudos oriundos dos países socialistas e a crise que se aprofundava na economia e na sociedade moçambicana ${ }^{351}$. Piorou a situação

\footnotetext{
${ }^{348}$ Segundo Mosca (2005), é fácil concluir que deixou de haver turismo e que grande parte das infra-estruturas foi abandonada, destruída ou utilizada para outros fins. A riqueza faunística foi dizimada pela guerra e pela caça furtiva que gerou negócios de carne na cidade.

${ }^{349}$ As relações com o COMECON não foram muito bem sucedidas, pelo fato desta organização interferir nas políticas internas de Moçambique: Adam (1990) refere que 21 projetos acordados só três foram iniciados. Em 1989 apenas dois estavam operacionais. A principal característica destes projetos era o fato de 90 por cento de o financiamento ter sido utilizado em assistência técnicas. O mesmo autor refere uma análise umas séries de razões justificam o falhando, normalmente: dificuldades de comunicação; deficiência no financiamento. Em muitos casos o seu fracasso, também é justificado pelas calamidades natural (cheias e secas cíclicas) e falta de capacidade para mitigá-las, os atos de agressão e destruição de infra-instrutoras econômicas e a conseqüente instabilidade, particularmente nas zonas rurais, provocadas pela guerra civil que começou em 1976. Aplicação integral de sanções ao regime racista e minoritário Rodesiano de Ian Smith (atual Zimbábue), em cumprimento da Resolução 253 (1968), aprovada em 29 de Maio de 1968 pelo Conselho de Segurança das Nações Unidas. Um dos fatores que assolavam era; inobservância contratual por parte de Moçambique; dificuldade de gestão; falta de adequados mecanismos de fiscalização e controlo. Estes fatores foram associados a outro como; a redução do recrutamento de mineiros moçambicanos para África do Sul, que reduziu também as divisas pagas nos salários dos mineiros que era em ouro; diminuição drástica da utilização dos Caminhos de Ferro e dos Portos moçambicanos pela África do Sul, a par do encerramento das fronteiras.

${ }^{350}$ Ver. Viera (1983), Bruck (1998), Cabaço (2007), mostra que a crise das economias socialistas, que foi surgindo refletiu fortemente na cooperação e na ajuda, em linhas de credito e a assistência técnica que se reduziam e os grandes projetos de desenvolvimento colapsavam, seja pela guerra, seja devido à redução dos apoios externos.

${ }^{351}$ Segundo Brochman (1990), estes países mantiveram maior importância no volume de relações, os valores eram
} 
política e militar regional que teve consequiências graves de se ultrapassarem no âmbito africano, onde se integrou no contexto da Guerra Fria ${ }^{352}$. Os aliados de Portugal (sobretudo a Alemanha ${ }^{353}$, os EUA, a França e a Inglaterra), mantiveram-se hostis a Moçambique até meados dos anos 1980. As relações com Portugal foram difíceis durante os primeiros anos, tendo-se verificado vários incidentes diplomáticos. Não obstante, por razões diversas, a cooperação bilateral e a veiculada por organismos internacionais do Ocidente estavam quase bloqueadas até meados dos anos 1980. A influência de cooperação com estes países se apresentou pela forma com que se processou a descolonização de Portugal e a sua dependência a em relação ao capital estrangeiro $^{354}$.

Foi a partir de princípios dos anos 1980, que surgem os primeiros sinais de uma grave crise econômica e é particularmente em 1983 que começa a ser tomada medidas que remeteram o país a mudanças das políticas na década dos anos 1980. Porém, na procura de mecanismo para estancar a crise econômica que Moçambique vivia, a FRELIMO realizou o IV Congresso em $1983^{355}$. Esse Congresso trouxe alavancas reformistas ligadas à descentralização e a orientação

elevados e abrangiam vários setores econômicos e sociais. É característico que depois dos primeiros anos 'formativos' de 1977-1982 a estrutura da ajuda regular não tivesse mudado muito.

352 Desinformação com, por exemplo, de se instalar uma base naval em Nacala ou em qualquer base militar em território moçambicano pela URSS. Faziam parte da Guerra Fria e pretendia fundamentar a teoria de Henry Kissinger sobre a "pinça" comunista da África Austral, bem com justificar a regionalização do conflito pela áfrica do Sul contra o "perigo comunista".

${ }^{353}$ No caso da República Federal Alemã (RFA), as relações mantiveram-se tensas em conseqüência de Moçambique reconhecer a existência das duas alemanhas, mantendo relações estreita com a República Democrática (RDA)

${ }^{354}$ Um dos impasses foi, após os acordos de Lusaka (7 de Setembro de 1974), pela insegurança do seu rumo, muitos portugueses começaram a depositar poupanças e valores nos consulados de Portugal, não apenas com o receio do que poderia passar-se com o sistema financeiro moçambicano, como ainda existia a expectativa de receber esses valores em Portugal. Em 1977 foram constituídas as comissões mistas de cooperação entre os dois países, mas apenas iniciaram o trabalho em 1982; a segunda reunião realizou-se em 1987. O impasse aplicado pelo governo português de "contencioso", isto é, um conjunto de dossiês sobre os quais não existia entendimento entre as partes; destacam-se os seguintes: o volume de recursos financeiros depositado pelos portugueses nos consulados de Portugal em Moçambique; os fundos da TAP; a questão da barragem de Cabora Bassa; etc. por outro lado, Portugal acusava Moçambique de não cumprir com os acordos de Lusaka no que respeita aos interesses dos portugueses e das empresas portuguesas; este país considerava que Portugal o deveria compensar das conseqüências econômicas da colonização. O "contencioso" foi desbloqueado a quando de uma visita do primeiro-ministro portugueses a Moçambique em 1989; a partir de então se iniciou a cooperação e as relações políticas e econômicas normalmente (ADAM, 1990).

${ }^{355}$ O quarto congresso da FRELIMO em 1983 foi o primeiro debate público ao nível interno sobre a estratégia de desenvolvimento. No congresso, os delegados criticaram a estratégia de desenvolvimento, o seu gigantismo e os esforços unilaterais nas estatais. Os delegados exigiam um aumento do apoio ás famílias camponesas e as cooperativas agrícolas. Foram também ouvidas vozes que defendiam que os empresários privados deveriam ter maior espaço de manobra na economia. Quando as decisões do congresso sobre outra orientação para a política agrícola o partido e o aparelho do estado deviam programar continuaram, na pratica, a exercer ser a mesma política anteriormente. A crítica dirigida contra a direção da FRELIMO no congresso de 1983 não era, em primeiro lugar, uma critica ao sistema político, mas o importante era o fato de os pequenos camponeses terem sido excluídos do 
para uma economia de mercado em pequena escala. Desse modo, Moçambique voltou-se mais uma vez a centrar a sua dependência econômica capitalista. Paralelamente, o presidente Samora Machel, fez uma ofensiva diplomática na Europa e nos EUA em 1984. Esta visita foi considerada em alguns círculos como uma viragem política que presumisse o abandono das cooperações entre Moçambique e os países socialistas ${ }^{356}$.

Em 1987 o governo propôs um novo programa de desenvolvimento, o Programa de Reabilitação Econômico (PRE), com objetivo de obter financiamento externo, para sustentar a crise econômica e política, centrada em dois pólos simultâneos, onde, por um lado, estava a crise financeira dos bancos que sediam empréstimo e, por outro lado, a crise econômica dos próprios países devedores. Como objetivo de viabilizar a economia e o crescimento dos recursos financeiros destinados aos setores sociais, e com uma maior prioridade para o setor familiar, a indústria ligeira e alimentar, também na rede comercial, quanto à recuperação das infrainstrutoras e do setor ferro portuário. De uma forma oficial esta política econômica foi o marcos da descontinuidade das medidas econômicas impostas na organização socialista ${ }^{357}$.

processo e de a população das zonas rurais terem sido desfavorecidos. Entretanto, a transformação política implicou uma alteração no sistema político. As modificações na política econômica não conseguiram satisfazer as exigências das famílias camponesas e da população rural (MOSCA, 2005).

${ }^{356}$ Assim sendo, como resultados desta visita, os países capitalistas criaram condições para ajudar Moçambique, desbloqueando alguns programas de ajuda, concedendo linhas de créditos, e compartilhando relações diplomáticas. Assim foi neste período inclusive que Moçambique saiu da lista negra americana (ABRAHAMSSON; NILSSON, 1994).

${ }^{357}$ Jeffrey (1999), esta política recuperou muita dos mecanismos de reprodução da economia colonial, a nível macro e micro, com o esvaziamento da capacidade técnica e de regulação por parte do Estado; a conversão da elite burocrática numa beneficiária de rendas intercedidas pelo poder; e a debilidade de um empresariado nacional com tradição, formado e nacionalista; conseqüentemente emerge um (re) capitalismo. A crítica ao sistema político só veio a ocupara um papel preponderante no debate público acuando do quinto e do sexto congressos da FRELIMO em no debate público a quando do quinto e do sexto congresso da FRELIMO em 1989 e 1991 respectivamente. Só então foram tomadas decisões, que levaram a alteração na constituição, e que abandonaram a via de desenvolvimento socialista em benefício da economia de mercado do sistema multipartidário. A primeira proposta para alterações á constituição moçambicana foi apresentada em 1988. Essa proposta consistia em pequenas mudanças no âmbito do sistema político existente e não levou a um grande debate. Em Janeiro de 1990 foi apresentada uma proposta de mudanças muito mais abrangente. Essa proposta foi discutida freqüentemente durante todo o ano nos meios de comunicação e em reuniões nos locais de trabalho e instituições em todo país. Com a nova constituição, Moçambique mudou de nome de República Popular de Moçambique para República de Moçambique, ao mesmo tempo em que o multipartidarismo é introduzido (MOSCA, 2005). 


\section{CONCLUSÃO}

Chegando ao fim do trabalho, conclui-se que algumas observações são extremamente necessárias ao abordar acerca da historia da economia socialista moçambicana, principalmente, em termos de opção de desenvolvimento econômico, estar relacionados com as bases de organização econômica do período colonial português, onde as suas bases estiveram ligadas à dependência de grandes investimentos estrangeiro. Nas regiões Norte e Cento, com algumas particularidades do Sul, tiveram uma pequena diferença na administração, mas o financiamento foi com base nos capitais estrangeiros. De principio os investimentos eram, principalmente, Inglesas, Francesa e Alemã. Assim sendo, o maior financiamento foi para construção de infra-estruturas de base sociais e fiscais necessária para promover a produção agrícola, bem como, para incentivar as funções de base de caráter administrativo. Sem receio de exagerar, podemos dizer mesmo que, a economia colonial como a socialista teve como base as receitas provenientes dos impostos cobrados pelo uso dos Portos e Estradas de Ferro, isto se deve a localização de Moçambique na região onde o acesso ao mar criou condições para o fornecimento de serviços portuário $\mathrm{e}$ terrestre para os países vizinhos.

A partir dos finais da década dos anos 1920, a política colonial portuguesa, ao corrigir as relações econômicas existentes, isto quer dizer, procurou reforçar a redução de capital estrangeiro, nas grandes empresas as de capitais estrangeiro ou misto. Foi o período do nacionalismo econômico, para acomodar uma burguesia que vinha paulatinamente perdendo referência no mercado. Porém, no inicio dos anos 1930 se propôs a imposição de um controle mais direto e rigoroso sobre os recursos das colônias. Uniformizando o sistema financeiro e administrativo, o Estado colonial, assumiu diretamente o controlo regular dos diferentes setores econômicos, com propósito de tornar as colônias eficientes na produção de matérias-primas necessária para o desenvolvimento industrial da metrópole.

De um modo geral, até após a Independência, as contas do Estado foram sustentado, principalmente, com base nos rendimentos provenientes da venda da força de trabalho, de serviços portuários e ferroviários. Entretanto, quando em 1975 se definiram as diretrizes econômicas de Moçambique independente havia uma necessidade de o novo Estado exercer um controla efetivo do sector financeiro e assim como, procurar o cumprimento dos objetivos da estratégia de desenvolvimento econômico e social. Herdeiro da gestão de todos os setores 
econômicos importantes dos portugueses que operavam em Moçambique, o novo Estado transformou as empresas capitalistas coloniais para empresas estatais. Essa política em direção ao socialismo foi acompanhada de anúncios da proibição das atividades privadas e qualquer iniciativa era social e politicamente condenada (eram os chamados novos exploradores).

Para os seus aliados econômicos a FRELIMO (Frente de Libertação de Moçambique), admitiu que o investimento financeiro, participasse nas atividades não estrategicamente de grande importância econômica, mediante o cumprimente dos critérios, de participação na produção nacional, no quadro dos objetivos fixados pelo Estado, e de acordo com os interesses das massas populares. Porém o processo da descolonização, permitiu um crescimento das empresas estatizado, o que levou o controle da economia através de uma política de economia centralmente planificada. Nestes casos, as transferências de recursos mantiveram-se através das exportações e os padrões de acumulação mantida do exterior. Entretanto, a manutenção destas empresas estatais dependia do recurso público, que era escassa. Muitos das empresas estatais herdadas do colonialismo eram empreendimentos abandonadas com meios de produção sabotados, que colocavam em crise os setores estratégicos da economia. $\mathrm{Na}$ sua maioria das empresas privadas a burocracia colonial não permitia um financiamento estrangeiro em maiores projetos, fora de investimentos em atividades das pequenas empresas, com alguma exceção especifica.

Entretanto, o processo da independência impôs transformações econômicas e ideológicas do país, que respondessem a nova realidade do desenvolvimento, sem investidores nacionais, mais com o Estado como o detentor dos meios de produção. Para tal, da agricultura, o novo Estado apoia-se por mecanismos de socialização do campo, partindo das Aldeias comunais, onde milhares de moçambicanos estavam aglomerados em redes de habitação, com vista agrupar forças e meio de produção. Nestas aldeias foram se desenvolvendo as experiências cooperativa de diferentes tipo e formas de organização, copiadas na economia dos países socialistas do leste europeu, com os diferentes ramos da atividade econômica (agrária, pesqueira, industrial, artesanal, consumo, habitação e serviços). A mais importante neste período era a cooperativa de produção agrícola que era a força motriz de transformações das aldeias comunais.

Às cooperativas de produção agrária, participaram na socialização progressiva do campo, constituindo, designadamente, um elemento fundamental de consolidação das aldeias comunais. As cooperativas de produção agrária seriam os dispositivos derradeiros com os quais a 
FRELIMO, apostou para o desenvolvimento de Moçambique. Podem ver isso, na Constituição de 1975, mais também nos slogans da época, "Produzir é Aprender, Aprender para Produzir e Lutar Melhor". 358 Porém, a reestruturação econômica, através da agricultura, abriu base para cooperativas agrícolas na região norte, centro e sul, foram marcados por características próprias quanto às origens e as motivações. Na região sul, principalmente se deveu as inundações dos anos 1977-1978, nos rios Incomáte e Limpopo, a população dos vales foram transferido e concentrado em aldeias comunais. Enquanto que, na zona norte de Moçambique os processos de cooperativas tiveram uma dinâmica diferente de oportunidades de se desenvolver, na suas maiorias se localizavam nas áreas de influência das grandes empresas estatais produtora de matérias primas. Outra dinâmica diz respeito àquelas aldeias cooperativas que se situam nas proximidades dessas unidades estatais, recebendo delas e da administração distrital os apoios técnicos, financeiros e logísticos mais diversificados.

Em geral, os rendimentos provenientes da agricultura na cooperativa, foram utilizados como fundo coletivo sem um fim determinado, para compra de equipamentos, abastecimento da cooperativa de consumo, pagamento de dívidas contraídas com aluguer de tratores, compra de sementes, etc. Muitas das cooperativas provinham da herança colonial com e outras recémcriadas, nas diretrizes econômicas do Terceiro Congresso da FRELIMO (1979), que direcionaram os planos econômicos ao modelo socialistas. Porém, as diretivas econômicas de 1977, estabeleciam aliança com os operários e camponeses. Mas também, foram definidas prioridades para as mudanças de um equilíbrio econômico estabelecido através de balanços materiais inter-setores, agricultura, como base e a indústria como o fator de desenvolvimento.

Neste modelo econômico socialista se destaca a importância do crescimento econômico se basear na indústria pesada como fator dinamizador que, viria a ser definido como o setor determinante para alcançar a independência e crescimento econômico. Ate então, o sector governamental, considerou a agricultura como a base do desenvolvimento e a indústria ligeira o fator dinamizador. Assim sendo, neste tipo de combinação econômico, as prioridades de investimentos eram para as seguintes áreas: agricultura, comércio interno e a oferta de serviços básicos á população. Porém, o setor estatal e as cooperativas seriam as bases para a construção do socialismo e considerados "formas superiores de produção", devendo as empresas estatais ser

\footnotetext{
358 Ver. Samora Moisés Machel. A Nossa Luta. Imprensa Nacional, 1975, Maputo. Com este texto iniciou o Departamento de Informação e Propaganda da FRELIMO, em 1971, a publicação de estudos fundamentais para a orientação e prática da organização.
} 
"dominantes e determinantes". E as aldeias comunais seriam a "coluna vertebral" do desenvolvimento do campo.

A gestão do sector externo obedece aos mesmos paradigmas, onde a planificação determinava em médio prazo as relações de cooperação e as empresas estatais de comércio externo funcionavam como organizações executoras obedecendo às quantidades a exportar e importar num sistema de câmbios fixos e preços administrativamente estabelecidos. Não obstante, o mercado internacional ser dominado pelas relações capitalistas, o modelo procurou um isolamento resultante da priorização das relações entre países socialistas, o fato é que não é possível o isolamento absoluto. As relações entre os sistemas capitalistas e socialistas continuaram a ser realizadas segundo as leis do mercado internacional controlado por organizações internacionais. Porém, o comércio internacional foi freqüentemente utilizado como instrumento político, mesmo, nas diretrizes realizadas posteriormente no Plano Econômico Central (PEC), que tinha como objetivo garantir as relações externas, incentivar relações diplomáticas com vista arrecadação de apoios dos países socialistas. Este plano procurou no Maximo obter acessos a recurso financeiro e, linhas de crédito, para reestruturar e programar a atividade do Estado.

Neste plano socialista, a inclusão das empresas privadas teve como necessidade de acesso a alguns recursos, sobretudo os bens importando, para tal, era contemplada no orçamento quando necessário. Na sua maioria os privados eram marginalizados e apenas contemplados quando a produção tinha uma importância, sobretudo para a exportação ou abastecimento interno. De forma coerente com estas opções, os camponeses apenas eram contemplados no plano na medida em que produziam excedentes de produção.

Não obstante, os recursos externos dos países socialistas serem avultados, uma boa capacidade organizacional e existência de expectativa, em todo o quadrante. Este período se caracterizou por um aprofundamento importante da crise que levaram a aprofundamento das políticas socialista, com o Plano Prospectivo Indicativo (PPI), que se desenvolveu na mesma diretriz econômica do Terceiro Congresso. Ela serviria para reforçar os sinais da recuperação econômica com um conjunto de metas e guia de ação fundamental para a construção e desenvolvimento socialismo, partia de eixos centrais, que levariam a socialização do campo e ao desenvolvimento agrário assentes em fatores fundamentais, como; o desenvolvimento acelerado do sector estatal agrário e a cooperatividade do campo. 
Neste sentindo, a expansão das cooperativas envolvendo camponeses num modo de vida coletivo nas (Aldeias Comunais), seria a força de trabalho, disponível para a produção, dotadas de normas e metodologias socialistas massificadas no trabalho. A integração do programa de cooperatividade e desenvolvimento do setor estatal agrário neste plano procuraram transformar a base socioeconômica do setor familiar, envolvendo os camponeses no modo de vida coletiva nas aldeias comunais, com produção coletiva centrada nas cooperativas e na produção individual.

O programa de desenvolvimento do setor estatal abarcava outros ramos de atividades para responder as explorações dos grandes projetos industriais. Entretanto, quanto aos transportes e comunicações tinha em vista a responder as necessidades dos setores de escoamento da produção dos grandes projetos, passando pela coordenação das atividades dos tipos de transportes e meios de comunicação existentes para o escoamento. Porém, o setor externo foi sempre importante na economia moçambicana, considerando importância crescente dos bens de consumo, sobretudo dos alimentares importações e exportações, os principais produtos são o mesmo do período colonial. Assim como, os parceiros comerciais são basicamente os mesmos e comportamento foram semelhante ao longo do período entre 1975 e 1985.

Após a independência, foram poucos os investimentos realizados em novas indústrias ou na modernização do parque existente. Os mecanismos protecionistas e o plano, os salários e os preços controlados, a política fiscal e cambial, o crédito estatal e os subsídios, etc., permitiram o funcionamento das empresas estatais independentemente da rentabilidade financeira e econômica. Também neste caso, esteve presente a mesma concepção de desenvolvimento tecnológico avançado em que não eram na maioria dominada localmente, com uma excessiva dependência sobre os trabalhadores estrangeiros. A combinação dialética entre conflito e políticas econômicas, a luta interna e agressividade externa em contexto de Guerra Fria estão na base da instabilidade econômica que se reflete em ciclos de crescimento relativamente rápidos e períodos de crises profundas cujas conseqüências os números não traduzem.

Nos princípios dos anos 1980, pela gravidade da situação começa a se tomar providencias para resolver a crise econômica que assolava Moçambique, precisamente, em 1983 começam os "ventos da mudança" com tomada de medidas que conduziram à adoção, do reajuste econômico com o Programa de Reabilitação Econômica (PRE) em 1987. Dentro das crises que se evoluíam remeteram o país a mudanças das políticas em 1989, introduzindo o 
Programa de Reabilitação Econômica e Social (PRES), que de uma forma oficial marcaram a descontinuidade das medidas econômicas impostas na organização socialista. 


\section{REFERÊNCIASDA BIBLIOGRÁFIA}

ABRAHMSSON, Hans e NILSSON, Anders. The Washigton Conensus e Moçambique. A importância de questionar o modo de pensar ocidental sobre o processo de desenvolvimento do continente Africano. Maputo: Centro de Estudo Estratégico e Internacionais do Instituto Superior de Relações Internacionais, 1995.

ADAM, Yussuf. Mueda 1917-1990: resistência, colonialismo, libertação e desenvolvimento. In: Arquivo Histórico de Moçambique. Cabo Delgado.Maputo:Arquivo Histórico de Moçambique. Boletim Semestral, $\mathbf{n}^{\circ} 14$ especial. Outubro de 1993.

.Escapar aos Dentes do crocodilo e Cair na Boca do Leopardo. Maputo: Promédia, 2005.ALTHUSSER, Louis - Aparelho Ideológico do Estado ( $8^{\mathrm{a}}$ edição). Rio de Janeiro, Ed. Graal, 2001.

ALAVI, H.A. The Structure of Peripheral Capitalism: in H. ALAVI \& T. Shanin (org). Introdution to Sociology of Developing Societies, 1982.

ARAÚJO, Manuel. As aldeias comunais e o seu papel na distribuição territorial da população rural na RPM. In: Rev. Finisterra. Vol. XVIII, n. ${ }^{\circ 36}$, Lisboa, 1983.

. O sistema das aldeias comunais em Moçambique: transformações na organização do espaço residencial e produtivo. Tese (Doutorado em Geografia Humana) -Universidade de Lisboa. Lisboa, 1988.

- Migração interna e o processo de urbanização. In: COMISSÃO NACIONAL DO PLANO \& DIREÇÃO NACIONAL DE ESTATÍSTICA. Dinâmica demográfica e processos econômicos, sociais e culturais. Maputo: Comissão Nacional do Plano \& Direção Nacional de Estatística, 1990.

Geografia dos povoamentos: assentamentos humanos rurais e urbanos. Maputo: imprensa Universitária, 1997.

. Espaço urbano demograficamente multifacetado: as cidades de Maputo e Matola.

Comunicação sobre as características geo-sócio-demográficas e os modelos de desenvolvimentos urbanos em Moçambique, 2006.

AMARAL, Ilidio. "Partilhas territoriais tradicionais e coloniais na África ao sul do Sara: Jogos políticos africanos no rescaldo da Guerra 1914-1918". In; II Reunião Internacional de História de África. Lisboa, Centro de Estudos de Historia e Cartografia Antiga, Instituto de Investigação Cientifica Tropical. 2000. 
ANDERSON, Perry. Portugal e o fim do ultra nacionalismo. Rio de Janeiro: Ed. Civilização Brasileira, 1966.

ADRSDE, Alfredo, A. Freire de. Colonização de Lourenço Marques. Porto. Typ. De A. J. Da Silva Teixeira, 1897.

ASKIN, S. Missão a RENAMO: a militarização da religião. In Caderno de História: Arquivo Histórico de Moçambique, p.53-77, 1990.

BAIÃO, António et al. História da expansão portuguesa no mundo. Volume I. Lisboa: Ática, 1937.

BANCO MUNDIAL. Informe sobre El Desarrolo Mundial. Washington, Banco Mundial (2003).

Indicadores de Desenvolvimento Mundial. Dados estatísticos em CD.Washington, Banco Mundial (2003).

. Mozambique. Restoring Rural Production and Trade.Vol, I e II.Washington, Banco Mundial (1990).

. Desarrollo . Experiencia del Banco Mundial, 1965-86. Washington, Banco Mundial (1988).

BELLUCCI, B. Economia Contempoânea em Moçambique: Sociedade Linhageira, Colonialismo, Socialismo, Liberalismo, 2007.

BELLUCCI, B. Tem, Mas Acabou Economia Contempoânea em Moçambique, 2005.

BERNADO, Manuel Amaro. Combater em Moçambique. Guerra e Descolonização, 19641975. Lisboa, Prefácio - Editores de Livros e Revistas, Lda.beralismo, 2003.

BOESEN, J. MADSEN, B. \& MOODY, T. Ujamaa Socialism from above.Uppsala, 1977.

BOtTOMORES, T. Dicionario do Pensamento Marxista. Jorge Zahar Editor. Rio de Janeiro. 1988.

BOLETIM DA COMPANHIA DO NYASSA nº 60, 28 de Fevereiro, ano de 1903, Porto Amélia. .nº 130, de 31 de Dezembro de 1908, Porto Amélia.

.nº 155, 30 de Janeiro 1911, Porto Amélia.

BOLETIM DA REPÚBLICA POPULAR DE MOÇAMBIQUE. №30. I Série. Lei n. ${ }^{\circ}$ 0/76, de 3 de Março de 1976. Determinava a alteração toponímica dos nomes das áreas urbanas moçambicanas. 
BOLETIM DA REPÚBLICA POPULAR DE MOÇAMBIQUE. №2 .I Série, Suplemento №2. Lei $n^{\circ}$ 4/86 de 25 de Julho, publicada, Sábado, 26.07.1986. Determinava a alteração do conteúdo normative do território colonial para pós-colonial.

BOLETIM DA REPÚBLICA POPULAR DE MOÇAMBIQUE. I Série, No 16 de 1987”. Resolução No 7/87 de 25 de Abril de 1987 que determina as cidades da República Popular de Moçambique".

BOLETIM DA REPÚBLICA DE MOÇAMBIQUE. Lei 3/94, I Série, $n^{\circ}$ 37, $1^{\circ}$ Suplemento, 13 setembro 1994. . Lei 9/96. I Série, $\mathrm{n}^{\circ}$ 47, $1^{\circ}$ Suplemento, 22 novembro 1996. . Lei 2/97, I Série ${ }^{\circ} 7,2^{\circ}$ Suplemento, 18 fevereiro 1997. . Lei 8/2003, I Série $n^{\circ} 20,1^{\circ}$ Suplemento, 19 de maio de 2003.

BOURDIEU, P. \& SAYAD, A. Le déracimement: La crise de l'agriculture traditionnelle en Algérie. Paris: Éd. Minuit. 1964.

BOXER, C. R.; AZEVEDO, Carlos.Relações raciais no império colonial português. São Paulo, Companhia das Letras, 1982[1963].

BOXER, C. R. O império colonial português. Lisboa, 1969.

BURGAT, François. Les villages socialistes de La révolution agraire algérienne: La place Du droit das Le Changement social.Thèse d'état, Grenoble, 1981.

BRITO, Luis de. Le Frelimo et la construction de l' État nactional au Mozambique. Le sens de la réfence au marxisme (1962-1983). Tese. (Doutorado em Antropologia do político), na Universidade de Paris VIII. Paris, 1991.

BRITO,Luís. "Dependência Colonial e Integração Regional". Estudos Moçambicanos, n. ${ }^{\circ} 1$. Maputo, Centro de Estudos Africano. 1980.

BRUCK, Tilman. Guerra e Desenvolvimento em Moçambique. Análise Social, Vol, XXXIII (149), 1998.

BROCHMAN, Grete, e Ofstad: Moçambique: A ajuda norueguesa num contexto de crise. Estado do país e exame da ajuda norueguesa. Francfort, Bergen, Noruega.1990.

CABAÇO, J. Moçambique: Identidade, Colonialismo e Libertação. 2007. 475f. Tese (Doutorado em Antropologia Social) - Programa de Pós-Graduação em Antropologia, Faculdade de Filosofia, Letras e Ciência Humana da Universidade de São Paulo. São Paulo, 2007. 
CABRAL, Amilcar. A arma da teoria. Rio de Janeiro. Cordeiros, 1980.

MACHEL, Samora. Estabelecer o poder popular para servir ás massas.Rio de Janeiro. CODERCRI, 1979.

FRELIMO: documentos fundamentales Del Frente de Libertación de Mozambique. Barcelona. Anagrama, 1973.

CABRITA, J. A morte de Samora Machel. Maputo: Edições Nova África, 2005.

CAHEN, M. Manifeste-programe de la RENAMO. Politique Africane. Paris/Karthala, 1988. . Etat de Pouvoir Populaire dans Le Mozambique Indépendant. In: Politique Africaine. n19, 1985.

Angola, Moçambique: que futuro para os crioulos. In: Inform África Confidencial, ${ }^{\circ}$ 63, 1994.

CAPELA, José. As burguesias portuguesas e a abolição do tráfico de escravatura, 18101842. Porto: CEA-UP (Edições eletrônicas),1987. Disponível em: <www.africanos.eu/ceaup/uploads/EB087.pdf>Acesso em: 2 mai. 2005.

.Moçambique pela sua história. Porto: CEAUP. (Edições eletrônicas), 2010. Disponível em <www.africanos.eu $>$. Acesso em: 20 de jan. 2012.

. O Escravismo Colonial em Moçambique. Porto: Afrontamento. 1993.

. "O Apriorismo Ideológico na História de Moçambique”. Em Moçambique, 16 Anos de Historiografia. Maputo, coleções Paínel Moçambicano. 1991.

O Imposto de Palhota e a Introdução do Modo de Produção Capitalista nas Colônias - As Idéias Coloniais de Marcelo Caetano - Legislação do Trabalho nas Colônias nos Anos 60. Porto: Afrontamento. 1777.

CAU, I.S. A Costrução do Estado Em Moçambique e as Relações com o Brasil. Porto Alegre. UFRGS. 201.

CARDOSO, Fernando Jorge. Gestão e Desenvolvimento. Moçambique no Contexto da áfrica Sub-sahariana.Lisboa, Fim de Século Edições. 1993.

Economias locais e empresas estatais agrárias em Moçambique (mercados oficiais e paralelos na zona da Maragra em 1983-85). Em Estudos de Desenvolvimento. África em Transição. UTL, ISEG, CEA. 2000.

CARVALHO, Anabela Soriano. Empresários em Temos de Guerra.O caso de Moçambique, 1974-1994.LusotopieXV. 2008. 
CARVALHO, Mário de. A Agricultura Tradicional de Moçambique. Junta de Investigação do Ultramar, Lourenço Marques: Imprensa Nacional. 1966.

CARVALHO, Nuno Fernandes Carvalho. Libras, Escudos, a Companhia de Moçambique e a cidade da Beira. Gabinete do Património Histórico da Caixa Geral de Depósitos, 2012

CASAL, A, Y. Discurso Socialista e camponeses africanos : Legitimação político-ideológico da socialização rural em Moçambique (Frelimo, 1965-1984). Revista Internacional de E studos Africanos, 1991.

ANTROPOLOGIA E DESENVOLVIMENTO. As Aldeias Comunais em Moçambique. Lisboa: Instituto de Investigação Cientifica Tropical, 1996.

A Crise da Produção Familiar e as Aldeias Comunais em Moçambique. Revista Internacional de Estudos Africanos. n ${ }^{\circ} 8$ e 9, 1988.

CASTEL-BRANCO, Nuno. Opções Econômicas de Moçambique 1975-95: Problemas, Lições e Ideias Alternativas. In: BRAZÃO, Mazula (editor). Moçambique Eleições, Democracia e Desenvolvimento. Maputo: Elo gráfica, 1995.

Indústria e industrialização em Moçambique: a análise da situação atual e linhas estratégias de desenvolvimento. Maputo: Ambascita d’Italia, 2003.

. Desafio do desenvolvimento rural em Moçambique: contributo crítico com debates de postulados básicos. Discussion Papers do Instituto de Estudos Sociais e Econômicos (IESE), 2008.

Sobre a "eficácia" e "eficiência" social e financeira da política econômica e as prioridades econômicas e sociais. Savana, 07 de janeiro 2014.

CASTElO, Cláudia. Passagem para África: o povoamento de Angola e Moçambique com naturais de Metrópole (1920-1974). Porto: Edições Afrontamento, 2007.

Investigação científica e política colonial portuguesa: evolução e articulações, 1936-

1974. História, Ciências, Saúde - Manguinhos, Rio de Janeiro, v.19, n.2, abr.-jun.2012.

Migração de metropolitano para Angola e Moçambique (1945-1974). VIII CONGRESSO LUSO AFRO BRASILEIRO DE CIÊNCIAS SOCIAIS. A QUESTÃO SOCIAL NO NOVO MILÉNIO. Coimbra, 16, 17 e 18 de Setembro de 2004.

CARDETINI, Onilia. Éléments d'une stratégie d'éco-développement pour lês villages ujamaa de La Tanzanie. Paris: CIRED, Maison dês Sciences de 1'Homme, 1974. 
CENTRO DE ESTUdos AFRICANOS. A Estrutura Econômica no Fim do Período

Colonial. Maputo: Centro de Estudos Africano, 1985.

.O mineiro Moçambicano: estudos sobre a expansão da mão de obra em Inhambane. Maputo: Centro de Estudos Africano, 1998.

CHICHAVA, Sérgio. Le “vieux Mozambique”. Etude sur l'identité politique de la Zambézie.

Tese. (Doutorado em Ciência Política). Instituto Político de Bordeaux-Centro de estudo de África negra da Universidade de Bordeaux IV. Bordeaux, 2007.

. Por uma leitura sócio-histórica da etnicidade em Moçambique. Maputo: IESE, 2008.

CHICO JÚNIOR, Manuel et al. Constituição da República de Moçambique: princípios e direitos fundamentais. 2 $2^{\mathrm{a}}$ Edição.Maputo: Konrad-Adenauer-Stiftung (Fundação Konrad Adenauer), 2010.

CHRISTIE, I. Machel of Mozambique. Harare: Zimbabwe Publishing House, 1988.

COELHO, João Paulo Borges. Tete, 1900-1926: o estabelecimento de uma reserva de mão de obra. In: Arquivo Histórico de Moçambique.Maputo:Arquivo Histórico de Moçambique. Boletim Semestral, $\mathrm{n}^{\circ} 10$ especial. Outubro de 1991, p.103-132.

COELHO, Vasco. Cooperação descentralizada e participativa entre Portugal e Moçambique: o exemplo do município da Matola. Disertação de Mestrado em Desenvlovimento e Cooperação Internacional. Instituto Superior de Econômia da UniversidadeTécnica de Lisboa, 2004.

COHEN, Jean-Louis. A cidade marxista. 1979. O urbanismo nas condições socialistas: URSS e países do leste europeu. In: FORTI, Reginaldo. Marxismo e urbanismo capitalista. São Paulo: Editora Ciências Humanas, 1979.

COLAÇO, J. Trabalho como política em Moçambique: do período colonial ao regime socialista. In: FRY, Peter (Org.). Moçambique ensaios. Rio de Janeiro9, 2002, p.91-110.

COLUMBIA ENCYCLOPEDIA 2007.Mozambique History.Sixth Edition.Disponível em: <http://www.encyclopedia.com/doc/1E1-Mozambiq.html $>$. Acesso em:13 jun. 2010.

COMISSÃO NACIONAL DO PLANO. Estatísticas dos Transportes e Comunicações 1989. Maputo, 1990.

COMISSÃO NACIONAL DO PLANO. Plano de Reconstrução Nacional 1994-96. Maputo, 1993. 
COMISSÃO NACIONAL DAS ALDEIAS COMUNAIS - O processo de desenvolvimento das aldeias comunais. Análise da situação. Proposta de atuação, 1979.

COMISSÃO NACIONAL DO PLANO. Informe estatístico, 1981

COMITÉ CENTRAL DA FRELIMO - Reunião. Comunicado final, 1966.

COMITÉ CENTRAL DA FRELIMO - 2. ${ }^{\mathrm{a}}$ sessão. Resoluções, 1968.

COMITÉ CENTRAL DA FRELIMO - 3. a sessão. Comunicado final. 1969.

COMITÉ CENTRAL — Relatório ao 3. ${ }^{\circ}$ Congresso, 1977.

CONFERENCIA EPISCOPAL DE MOÇAMBIQUE. A paz que o povo quer. Maputo: CEM 1987.

CONGRESSO DA FRELIMO (I) - 23-28/9/1962.

CONGRESSO DA FRELIMO (II) - 20-25/7/1968.

CONGRESSO DA FRELIMO (III) — Diretivas econômicas e sociais, 1977.

CONGRESSO DA FRELIMO (IV) - Relatório sobre a preparação do IV Congresso. Teses para o 4. ${ }^{\circ}$ Congresso. Diretivas Econômicas e Sociais, 1982.

CONSELHO AGRÁRIO (II) — Ministério da Agricultura, 1977.

CONSELHO AGRÁRIO (III)-Ministério da Agricultura, 1978.

CONSELHO CONSULTIVO DO GODCA-Ministério da Agricultura, 1979.

CONSELHO DE MINISTROS —26 de Julho de 1975.

CONSELHO DE MINISTROS — 5. ${ }^{a}$ sessão alargada. Reunião sobre Cooperativização, 1982.

CONSTITUIÇÃO DA REPÚBLICA DE MOÇAMBIQUE. Maputo: Impresa Nacional. 2004.

CONSTITUIÇÃO DA REPÚBLICA DE MOÇAMBIQUE. 1975

COSTA, A. A Pobreza, a guerra e a paz em Moçambique: teorias, relações e percepções.

Texto apresentado na conferência "Dinâmica da pobreza e padrões de acumulação econômica em Moçambique, Maputo de 22-23 de abril.” Maputo: IESE, 2009.

COSTA, Eduardo. O território de Manica e Sofala e a administração da Companhia de Moçambique, 1892-1900. Lisboa, Typ. Da Comp. Nacional Editora, 1902.

COSTA. Inês Nogueira. No centenário da Companhia de Moçambique, 1888-1988. In: Arquivo Histórico de Moçambique. Cidade da Beira.Maputo:Arquivo Histórico de Moçambique. Boletim Semestral, ${ }^{\circ} 6$ especial. Outubro de 1989.

COSTA, Mário. Origem e primeiros passos da Beira. Boletim Geral das Colônias. XV - 174. Agência Geral das Colônias. № 174 - Vol. XV, 1939. 
COUTO, Fernando Amado. Moçambique, 1974: o fim do império e o nascimento da nação. Miradela: Caminho,2011.

COVANE, Luís António. Lourenço Marques e o transvaal, 1852-1928. In: Arquivo Histórico de Moçambique. Centenário da cidade de Maputo, 1887-1987.Maputo:Arquivo Histórico de Moçambique. Boletim Semestral, n 2 especial. Outubro de 1989.

. As Relações econômicas entre Moçambique e a África do Sul, 1850-1964; acordos e regulamentos principais. Maputo: Arquivo Histórico de Moçambique. 1989. Agricultura colona, comércio rural e trabalho migratório no vale do Limpopo, 1900-1950. III Reunião Internacional de História de África.Lisboa, Centro de Estudos de História e Cartografia Antiga, Instituto de Investigação Científica Tropical,2000.

$\begin{array}{lllll}\text { CRAWFURD, } & \text { J. } & \text { Mozambique. } & \text { Timeline. }\end{array}$

Disponívelem: $<$ http://crawfurd.dk/africa/mozambique_timeline.htm $>$. Acesso em: 13 jun. 2010.

CUNHA, Pedro José da. A Companhia de Moçambique e a sua obra.Boletim Geral das Colónias. Agência Geral das Colónias. Nº 005 - Vol. I. 1925.

DAMIÃO, E. Esboço da história social e económica (1900-1994) e o impacto da guerra (1983-1992) no Distrito de Malema, Nampula. 1996.76f. Monografia. (Licenciatura em História) - Faculdade de Letras e Ciências Sociais da Universidade Eduardo Mondlane, Maputo: UEM, 1996.

DAVA, Fernando. Autoridade tradicional no contexto da colonização portuguesa: caso do Sul de Moçambique, 1895-c.1930. III Reunião Internacional de Historia da África. Lisboa, Centro de Estudos de História da África e Cartografia Antiga, Instituto de Investigação Ciêntifica Tropical, 2000.

DEPARTAMENTO DE INFORMAÇÃO E PROPAGANDA DA FRELIMO - O processo de revolução democrático-popular em Moçambique, 1974.

DEPARTAMENTO DE HISTÓRIA, UNIVERSIDADE EDUARDO MONDLANE. História de Moçambique: vol. 1 : Sociedades sedentárias e impacto dos mercadores (200/300-1886). Maputo : tempo, 1982.

DEPARTAMENTO DE HISTÓRIA, UNIVERSIDADE EDUARDO MONDLANE. Históriade Moçambique: vol. 2 : Agressão imperialista, 1880-1930. Maputo : tempo, 1983. 
DEPARTAMENTO DE HISTÓRIA, UNIVERSIDADE EDUARDO MONDLANE. História de Moçambique: vol. 3 : Moçambique no auge do colonialismo, 1930-1961. Maputo : tempo, 1993.

DIAS, Jorge. Os Macondes de Moçambique. Junta de Investigação do Ultramar, Lisboal.1960.

DINERMAN, A. In Search of Mozambique: The Imaginings of Christian Geffray in La Cause des Armes au Mozambique: Anthropologie d'une Guerre Civile, Journal of Southern African Studies.20 (4), 1994.

DIREITO, Barbara. Política colônias de terra em Moçambique: o caso de Manica e Sofala sob a Companhia de Moçambique, 1892-1942.Tese.(Doutorado em Ciências Políticas). Instituto de Ciências Sociais da Faculdade de Letras e Faculdade de Direito da Universidade de Lisboa, 2012.

DIREÇÃO DOS SERVIÇOS DE PLANEAMENTO E INTEGRAÇÃO ECONOMICA.III Plano de Fomento. Lourenço Marques. 1966.

IV Plano de Fomento. Lourenço Marques. 1966.

ENNES, António. O trabalho indígena e os créditos agrícolas. Antologia Colonial Portuguesa. Vol I. Política e Administração. Lisboa: Agência Geral da Colonias, 1946.

.Moçambique: relatório apresentado ao Governo. $4^{\text {a }}$ edição. Lisboa: Imprensa Nacional, 1971.

ENZENSBERGER, Hans Magnus. Guerra Civil. São Paulo: Compahia das Letras,1995

ERGÖ, B. Moçambique: os Primeiros dez anos da construção da Democracia. Maputo: AHM, 1992.

ESTATUTO-TIPO PARA AS COOPERATIVAS DE PRODUÇÃO AGRÁRIA, 1971

FANON, Frantz. Os condenados da terra. Juiz de Fora: UFJF, 2005.

FAUVET, P.;GOMES, A.The Mozambique National Resistance.Supplement to AIM Information Bulletin 69 (March 1982).

FELICIANO, J. Antropologia econômica dos Thonga do sul de Moçambique. Maputo, Arquivo Histórico de Moçambique, 1998.

FERNANDES, Jorge. República [popular de Moçambique]. As alterações toponímicas e os carimbos do correio. Porto: Humus, Lda,2006.

FIRMINO, Gregório. A situação do português no contexto multilíngue de Moçambique. Palestra proferida na Faculdade de Letras e Ciências Humanas da Universidade de São Paulo. 
2006. Disponível em: < http://www.fflch.usp.br/dlcv/lport/pdf/mes/06.pdf>. Acesso em: 20 maio 2012.

FLORÊNCIO, F. Christian Geffray e a antropologia da guerra: ainda a propósito de la cause des armes au mozambique. Etnográfica. Vol. VI (2), 2002.

FRANCISCO, António A. Silva. 2003. "Reestruturação económica e desenvolvimento". In :Boaventura de Sousa Santos e João Carlos Trindade (Organizadores). Conflito eTransformação Social: Uma Paisagem das Justiças em Moçambique. Porto: Edições Afrontamento, 2003.

FRY, Peter. Cultura da Diferença: Sequelas das Políticas Coloniais Portuguesas e Britânicas na África Austral. Rio de Janeiro. Afro-Ásia.29/30, 2003.

FREIRE DE ANDRADE, Alfredo. Trabalho indígena e as colônias portuguesas - A escravatura e a sociedade das Nações. In: Boletim de Agência Geral das Colônias. Lisboa: Agência Geral das Colônias, n¹6, outubro 1926.

FURTADO, Celso. Economia colonial no Brasil nos séculos XVI e XVII (Elemento de história econômica aplicada à análise de problemas econômicos e sociais). São Paulo: Hucitec, 2001.

GALVÃO, Henrique. Álbum comemorativo da $\mathbf{1}^{\mathbf{a}}$ exposição colonial portuguesa. Porto: Agência Geral das Colonias. 1934.

GALVÃo, J. O regime da mão de obra em Moçambique. Boletim da Agência Geral das Colonias, $n^{\circ} 3$, setembro 1925.

GEFFRAY, C. A causa das armas: antropologia da guerra contemporânea em Moçambique. Afrontamento: Porto,1991.

GENTIL, A Maria. O Leão e o caçador. Maputo. Arquivo Histórico de Moçambique.Estudos 14,1999 .

_“A subversão no distrito de cabo delgado -1950 - 1960, segundo as fontes administrativas locais".Em Moçambique, 16 Anos de Historiografia. Maputo, coleção Painel Moçambicano, 1991.

GODCA (Ministério da Agricultura) — Projeto de ação de cooperativização,1982.

GODCA (Ministério da Agricultura) - Contribuições para o programa de cooperativização do campo, 1982. 
HAMELA, Hipólito. Moçambique: Economia de Mercado ou Socialismo do Capital?Maputo: Ndjira, 2003.

HANLON, J. Mozambique the revolution under fire. London: Zedbooks, 1990.

HANLON, J. Peace without profit. Haw the IMF blocks rebuilding in Mozambique. African Issues. London:Villiers Publications, 1996.

HEDGES, David. Moçambique no auge do colonialismo, 1930-1961: a economia e estrutura social. In: , et al. (Coord.). História de Moçambique: Moçambique no auge do colonialismo: 1930-1961. Maputo: Universidade Eduardo Mondlane, 1993.

HERMELE, Kenneth.Guerra e Estabilização. Uma Análise e Médio Prazo do Programa de Recuperação Econômica de Moçambique.Revista Internacional de Estudo Africano, n. 8 e 9. 1988.

HODGES, T. ANGOLA: Do Afro-estalinismo, ao Capitalismo selvage. Principia Pubbicações Universitária e cientifica, $1^{\mathrm{a}} \mathrm{Ed}, 2002$.

HUGON, Fhilipp. Economia de África. Lisboa, Editora Vulgata. 1999.

ISAACMAN, Allen. "Camponeses, trabalho e processo de trabalho. $\mathbf{O}$ cultivo forçado de algodão em Moçambique colonial (1938-1961)". Em Moçambique, 16 Anos de Historiografia. Maputo, coleçãoPainel Moçambicano. 1991.

;Mozambique the africanization of european institucion the Zambezi prazos 17501902. The university of Wiscosins press. Madison/wilwaukee e Londres, 1972.

;A Tradição de Resistência em Moçambique. O Vale do Zambeze, 1852-1927. Porto, Afrontamento.1979.

JANESICK, V. Stretching exercises for qualitative researchers. Thousand Oaks, CA: Sage, 1998.

JONES, J. Portuguese Activity in East África, 1498-1700.Timeline1998.Disponível em:<http://courses.wcupa.edu/jones/his311/timeline/t-port.htm>.Acesso em: 14 jun. 2012.

JOSÉ, Alexandrino. O operário moçambicano e a sua história. In: Arquivo Histórico de Moçambique. Centenário da cidade de Maputo, 1887-1987.Maputo:Arquivo Histórico de Moçambique. Boletim Semestral, n 2 especial. Outubro de 1989, p.144-162.

Beira: lembranças da cidade colonial. In: Arquivo Histórico de Moçambique. Cidade da Beira.Maputo:Arquivo Histórico de Moçambique. Boletim Semestral, $\mathrm{n}^{\circ} 6$ especial. Outubro de 1989, p.181-200. 
KALECKI, Michal. Economia socialista e mixta. Madrid: Fundo de Cultura Econômica, 1986.

LACERDA, Francisco. O trabalho indígena em Moçambique. Boletim de Agência Geral das Colonias. № 46, abril de 1929.

LEI DAS TERRAS— 4. a sessão da Assembléia Popular, 1979.

LEI DAS COOPERATIVAS, 1980.

LEITE, Joana; KHOURI, Nicole. Os Ismailís de Moçambique: vida econômica no tempo colonial. Lisboa: Edições Colibri, 2012.

LEITE, Joana. A formação da economia colonial em Moçambique. Pacto colonial e Industrialização: do colonialismo português às redes informais de submissão mercantil, 193074. Estudos de Desenvolvimento. África em Transição. UTL, ISEG, CESa: Lisboa, 2000.

Colonialismo e industrialização de Moçambique: pato colonial, dinamização das exportações e "importação de substituição” 1930-74. Ler História, 24.1993.

LEMOS, Manuel. Recenseamento populacional em Moçambique colonial. In: Arquivo Histórico de Moçambique.Maputo:Arquivo Histórico de Moçambique. Boletim Semestral, $\mathrm{n}^{\circ} 1$ especial. Abril de 1987.

LISEGANG, Gerhard. Archaeological sites on the bay of Sofala.Azania: Archaelogical Research in Africa. Volume 7. Issue 1. 1972.

LOBATO, Manuel. Os regimes de comércio externo em Moçambique nos séculos XVI e XVII. In: Povos e culturas. CEPCEP. UCP. 5. 1996.

.Evolução administrativa e a economia de Moçambique, 1752-1763. Lisboa: Agência Geral do Ultramar, 1962 b.

. Sobre as causas da ocupação tardia do Norte, num relance pela História de Moçambique. Boletim da Comissão dos Monumentos Nacionais de Moçambique, $\mathrm{n}^{\circ} 7$. Lourenço Marques: Tip.Emol- L.M. 1972.

MACHEL, S. O partido e as classes trabalhadoras moçambicanas na edificação da democracia popular. Relatório do Comitê Central ao $3^{\circ}$ Congresso. Maputo: Departamento Ideológico da FRELIMO, 1977.

.A Nossa Luta. Imprensa Nacional, 1975, Maputo. Com este texto iniciou o Departamento de Informação e Propaganda da FRELIMO, em 1971, a publicação de estudos fundamentais para a orientação e prática da organização.

.Produzir é aprender. A prender para produzir e lutar melhor, 1971. 
. A produção e o comercio nas zonas libertadas: in. Ver. Tempo, n. ${ }^{\circ}$ 201, 28/7/1974.

.Discurso de abertura do 1. ${ }^{\circ}$ Seminário Nacional de Agricultura. Marrupa, 29/5/1975.

. XXXXXXX O processo da revolução democrático-popular em Moçambique. Lourenço

Marques. Imprensa Nacional, 1975.

. Estabelecer o poder popular para servir as massas.Lourenço Marques. Imprensa

Nacional, 1975.

.discurso da tomada de posse, 25 de Junho de 1975.

. Façamos de 1980-1990 á década da vitória sobre o subdesenvolvimento, 1979.

. Discurso de inauguração da 8. ${ }^{a}$ sessão da Assembléia Popular, 1981.

.Acordo de Nkomatí: Vitória do socialismo, 1984.

MACKINTOSH, Mauren; WUYTS, Marc.“Accumulation, social services and socialist transition in the third wold: Refletions on descentralised planningbased on the Mozambique experience". In : E. V. K. Fitzgerald and M. WUYTS (eds), Markets Within Planning. Socialist Economic Planning in the Third World. London. Frank . 1988.

MALOA, Joaquim. A urbanização moçambicana: uma proposta de interpretação. Tese de doutorado em Geografia Humana. Universidade de São Paulo. 2016 ( mimeo).

MAZZEO, Antonio Carlos. Estado e Burguesia no Brasil: origens da autocracia burguesa. 3.ed. São Paulo: Boitempo, 2015. .

MEDEIROS, Eduardo da Conceição. História de Cabo Delgado e do Niassa (c. 18361929).Maputo : [s.e.], 1997.

MENDES, Maria Clara. Maputo antes da independência: geografia de uma cidade colonial. Tese de Doutorado. (Geografia urbana) - Universidade de Lisboa, 1979.

(Coord.). Urbanização colonial: os planos de urbanização nas antigas províncias ultramarinas, 1934-74. Lisboa: Faculdade de Arquitetura da Universidade Técnica de Lisboa, 2008.

MENDES, Rui. A cidade colonial e a estruturação do território em Moçambique: a evolução urbana de Lourenço Marques/Maputo, Beira, Nampula e Porto Amélia/Pemba. Tese (Doutorado em Geografia). Faculdade de Letras da Universidade de Porto. Porto, 2011.

MINAYO, M. O desafio do conhecimento. São Paulo: Hucitec,1993.

MINISTERIO DA MARINHA E ULTRAMAR, 1897, BOLETINS DA COMPANHIA DO NIASSA, 1903, 1908, 1911 
MINISTERIO DAAGRICULTURA — Planificação 83 - 85, 1982.

MINISTERIO DA INDÚSTRIA E COMÉRCIO - Vamos desenvolver as nossas cooperativas de consumo, 1975.

MINISTERIO DAS OBRAS POBLICAS E HABILITAÇÃO — Normas de organização física de uma aldeia comunal, 1975.

MINTER,W. The Mozambican national resistance (RENAMO) as described by exparticipants. Washington DC: Ford Foundation e Swedish Internation Development Agency, 1989.

MISSÃO DE INQUÉRITO AGRÍCOLA1970. Lourenço Marques: Missão de Inquérito Agrícola, 1973.

MONDLANE, E. Lutar por Moçambique. Maputo: Nosso Chão, 1995.1 a edição moçambicana. MOSCA, João .A experiência Socialista em Moçambique (1975 - 1986).Lisboa: Instituto Piaget, 1999.

. Economia de Moçambique, Século XX. Lisboa: Editora Instituto Piaget, 2005.

. Pobreza, "informalidade" e desenvolvimento. II CONFERENCIA DO INSTITUTO DE ESTUDO SOCIAIS E ECONOMICOS (IESE)- "DINÂMICA DA POBREZA E PADRÕES DE ACUMULAÇÃO ECONÔMICA EM MOÇAMBIQUE”. Maputo, entre os dias 22 e 23 $\begin{array}{llll}\text { de } & \text { abril } & \text { de } & \text { Disponível }\end{array}$ em: $\langle$ http://www.iese.ac.mz/lib/publication/II_conf/CP34_2009_Mosca.pdf $\rangle$. Acesso em: 02 de fev. 2015.

MOURA, Francisco de, e AMARAL, Maria Fernanda (s/d): Estimativa do Produto Interno Bruto de Moçambique.Maputo, Universidade Eduardo Mondlane, Curso de Economia.

MUANAMOHA, Ramos. Tendências históricas da distribuição espacial da população em Moçambique. Dissertação (Mestrado em Demografia) - Centro de Desenvolvimento e Planejamento Regional da Faculdade de Ciências Econômicas da Universidade Federal de Minas Gerais, Minas Gerais. Belo Horizonte, 1995.

MUHATE, Isaias. Alguns aspetos do retrato histórico e perspectiva do porto da Beira. In: Arquivo Histórico de Moçambique. Cidade da Beira.Maputo:Arquivo Histórico de Moçambique. Boletim Semestral, ${ }^{\circ} 6$ especial. Outubro de 1989.

MUNSLOW, B. Mozambique: the revolution and its Origins. London: Longman, 1983. 
Dinâmica demográfica e suas implicações em Moçambique. Maputo: Centro de Pesquisa em População e Saúde [Gazeta de População e Saúde nº 02], 2014.

NEGRÃO, José. Cem Anos de Economia da Família Africana. Maputo, Promédia. 1991.

NEVES, Joel das. Tete e o trabalho migratório para a Rodésia do SUL, 1890-1913. In: Arquivo

Histórico de Moçambique.Maputo:Arquivo Histórico de Moçambique. Boletim Semestral, $\mathrm{n}^{\circ}$ 10 especial, 1991.

NEWITT, Malyn. História de Moçambique. Mira-Sintra-Mem Martins: Publicações EuropaAmérica,1997.

. O Período de Imperialismo Europeu em Moçambique. Revista Internacional de Estudos Africanos, n. ${ }^{\circ} 6$ e 7,1987.

O’LAUGLIN, B. Proletarianisation, Agency and Changing Rural Livelihoods: Forced Labour and Resistance in Colonial Mozambique. Journal of Southern African Studies, volume 28, number, 2002.

.A base social da guerra em Moçambique - análise de á causa das armas em Moçambique - antropologia de uma guerra civil de C. Geffray. In: Estudos Moçambicano. CEA, nº10. Maputo: CEA/UEM, 1989.

OSMAN, A. M. Moçambique: Políticas para o Pós-Guerra. Expresso, 18 de Janeiro e 15 de Fevereiro 1992.

PASSADOR, Luiz Henrique. Guerrear, casar, pacificar, curar: o universo da "tradição" e a experiência com o HIV/Aids no distrito de Homoíne, Sul de Moçambique. 269 f. Tese (Doutorado). Programa de Pós-graduação em Antropologia Social, Universidade Estadual de Campinas, Campinas. 2011.

PEREIRA, F. A particularidade da dinâmica do conflito armado no distrito de AltoMolócuè (1982-1992): violência armada e guerra mágica. 1999. 121f. Monografia. (Licenciatura em História) - Faculdade de Letras e Ciências Sociais da Universidade Eduardo Mondlane, Maputo: UEM, 1999.

PEISSIER, René. História de Moçambique : Formação e oposição 1985-1918. Lisboa. Vol2. Editorial Estampa, 1988.

PENVENE, Jeanne Marie. “A Luta continua Literatura recente sobre Moçambique”. Revista Internacional de Estudos Africanos, n. ${ }^{\circ} 3.1985$. 
.. A history of African Labor in Lourenço Marques, Mozambique, 1870-1959.Tese of Phd, University of Boston, 1982.

PITCHER, M.A.Sobrevivência à transição: o legado das antigas empresas coloniais em Moçambique. Análise Social, v. XXVIII (168), 2003.

PLUMB, J.H. Introdução. In: BOXER, C. R. O império colonial português. São Paulo: Edições 70, 1969.

PLANO PROSPETIVO-INDICATIVO PARA A DÉCADA DE 1980, 1981.

PRADO JÚNIOR, Caio. Formação do Brasil contemporâneo: colônia. São Paulo: Brasilense.2000.

PROGRAMA DO PARTIDO FRELIMO, 1977.

QUEMBO, C. Le pouvoir du pouvoir: l'Operação produção(1983) et la construction des « improductifs » urbains au Mozambique. Mémoire pour le Master - Sciences Politiques. UniversitéBordeaux, 2010.gra: Vol. I

KI-ZERBO, J. Historia da África Negra. Mem Martins: Publicação Dom Quixote, vol 2, 1992.

KI-ZERBO, J. (Coord) Historia Geral da África: vol I, Metodologia e pré-história de África. São Paulo; [Paris]: Ática; Unesco, 1985.

KONDER, Leandro. O Marxismo na Batalha das Ideias. $2^{a}$ edição. São Paulo, Editora Expressão Popular, 2009.

REZENDE, C. História Economica Geral. São Paulo: Manuais contexto, 1995.

REPÚBLICA POPULAR DE MOÇAMBIQUE. Constituição da República popular de Moçambique - 1975. Maputo: Imprensa Nacional de Moçambique, E.P, 2013.

. Constituição da República de Moçambique. Maputo: Imprensa Nacional de Moçambique, E.P, 1990 e 2004.

REUNIÃO NCIONAL DOS BAIRROS COMUNAIS - Resolução sobre o plano geral de ação das cidades para 1979-1980. Maputo, Imprensa Nacional de Moçambique, 1979 REUNIÃO NCIONAL DAS ALDEIAS COMUNAIS, 1980.

RITA-FERREIRA, António. Povos de Moçambique: história e cultura. Porto: Afrontamento, 1975.

Evolução da mão de obra de remuneração no setor privado em Moçambique, desde 1950-1970. Lourenço Marques: Associação Industrial de Moçambique, 1971. 
. Fixação Portuguesa e história pré-colonial de Moçambique. Lisboa, Junta de Investigação Científica Tropical, 1982.

. O movimento migratório dos Trabalhadores entre Moçambique e a África do Sul.

Lisboa, Junta de Investigação do ultramar, 1963.

ROBERTS, Richard. Por dentra das finanças internacionais. Rio de Janeiro: Zahar, 2000.

ROCHA, Aurélio.Lourenço Marques: classe e raça na formação da classe trabalhadora. $\mathrm{O}$ caso

do setor ferro-portuária de Lourenço Marques, 1890-1910. Maputo: Universidade Eduardo Mondlane, 1985.

.Os suaíli de Moçambique: síntese histórico-cultural de uma sociedade africana (das origens ao fim do século XVIII). UNL. FCSH. Mestrado de História dos descobrimentos e da expansão portuguesa. SEMINÁRIO DEAFRICA AO SUL DO SAHARA. Lisboa. 1987.

.Aculturação e Assimilação em Moçambique". In. Actas do Seminário -

Moçambique: Navegação, Comércio e Técnicas. Lisboa: Ed. Comissão Nacional para as Comemorações dos Descobrimentos Portugueses, 1998.

."Associativismo e Nativismo em Moçambique: Contribuição para o estudo das Origenm do Nacionalismo moçambicano (1900-1940). Maputo. Promedia, 2002.

.Associativismo e nativismo em Moçambique... Grêmio Africano de Lourenço Marques (1908-1938)", Dissertação. (Mestrado em Economia e Sociologia Histórica). Universidade de Lisboa. Lisboa, 1991

ROEMER, J. M. A future for socialism. Cambridge: Harvard University Press, 1994.

ROSÁRIO, Lourenço do. Da Guerra Colonial, versos Luta Armada de Libertação - política história e identidade". In TEXEIRA, Rui de Azevedo (org.) Aguerra Colonial. Lisboa. Noticias, 2001.

II Congresso sobre a Luta de Libertação Nacional/ Guerra Colonial. 27 Anos Depois. A Reflexão Possivel. Maputo,.ISPU., 2004.

ROSAS, Fernando. O Estado Novo nos Anos 30; 1928-1938. Lisboa: Editoral Estampa, 1986. . "O marcelismo ou a falencia da politica de transição no Estado Novo". In BRITO, J. M. Brandão de (Cord.),Do Marcelismo ao Fim do Império. Lisboa: Ed. Noticias, 1999.

SALAZAR, Antonio de Oliveira. Discurso e notas políticas (3. ${ }^{\circ}$ Vol). Coimbra:Coimbra Editora, 1943.

.Textos de Salazar sobre política ultramarina. Lisboa, S.I., 1954. 
.O ultramar português e a ONU. Lisboa, SNI, 1961.

SAUL, Jonh S. A Dificult Road. The Transition to Socialism in Mozambique.York, Monthly Review Press. 1985.

.O marxismo-leninismo no contexto moçambicanica. Maputo, UEM,1983.

SAÚTE, Nelson J. Pedro.Crônica de uma integração imperfeita: o caso da privatização da gestão dos portos e caminhos de ferro em Moçambique. 2010. 194f. Dissertação (Mestrado em Sociologia) - Programa de Pós-Graduação em Sociologia, Faculdade de Filosofia, Letras e Ciência Humana da Universidade de São Paulo. São Paulo, 2010.

SECCO, Lincoln. A revolução dos cravos. São Paulo, Amemeda, 2004.

SERRA, Antonio Manuel de Almeida. "os três anos que abalaram Moçambique”. In: Estudos de Desenvolvimento. Africa em Transição. UTL, ISEG, CEsA. TRINOVA, 2000.

SERRA, C. Como a Penetração Estrangeira Transformou o Modelo de Produção dos CamponesesMoçambique. Maputo, Imprensa Nacional, 1986 .

.Novos Combatentes pela Mentalidade Sociológica. Maputo: Imprensa Universitári aUEM,1997.

.Pluralidade e processualidae identitárias - para um paradigma de identificação

contraditórial. In: SERRA, Carlos (org.) oIdentidade, Moçambicanidade,

Moçambicanização. Maputo, Livrariauniversitária (UEM), 1998.

."Introdução". In: SERRA, Carlos (dir.) Conflitos e Mestiçagem. Maputo,

Livrariauniversitária (UEM), 2000.

SILVA, T, C. Educação, Identidades e Consciência Politica: A Missão Suiça no Sul de

Moçambique (1930 - 1975): the cae of the Swiss mission, Bradford, University of Bradford,

Ph. D thesis, 1996.

.Educação, identidade e consciência política: A Missão Suíça no Sul de Moçambique (1930-1975). In: lusotópie 1998. Paris: Ed. khartala, 1998.

.“A Missão suíça em Moçambique e a formação da juventude: a experiência de Eduardo

Mondlane (1930-1975). In: Estudos Moçambicanos n. ${ }^{\circ}$ 16, Maputo, Imprensa Universitaria (UEM), 1999.

SOUZA, Maria Adelia. A identidade da metrópole: a verticalização em São Paulo. São Paulo: Edusp, 1994. 
SOUTO, Amélia; SOPA, Antônio. Samora Machel: bibliografia (1970-1986). Maputo: Centro de Estudos Africanos da Universidade Eduardo Mondlane (Coleção Nosso Chão), 1996.

SOPA, António. (Ed). Samora, homem do povo. Maputo:e Manguezo, 2001. .Southern Africa and the Soviet Union. London: Macmillan, 1993

SCHAFER, J. Soldiers at peace: veterans of the civil war in Mozambique. Palgrave: Macmillan, 2007.

SWEEZY. P, M. "Socialismo". Rio De Janeiro, 3ed, Zahar Editores, 1967.

SKANDERA, R. Origens do Pensamento Econômico e das práticas Adminstrativas. FGV, Rio de Janeiro, 1973.

TAJÚ, G. Renamo: os fatos que conhecemos. In: Caderno de História. Maputo: Universidade Eduardo Mondlane,1988, p.5-44.

TEIXEIRA, Manuel, «Portuguese traditional settlements, a result of cultural miscegenation», in Traditional Dwellings and Settlements Review, vol. 1, 2 (1990),p. 23-34.

THIOLLENT, M. Critica metodológica, investigação social e enquete operaria. $5^{\text {a }}$ edição, São Paulo: Polis, 1987.

THOMAZ, Fernanda. "Os filhos da terra": discurso e resistência nas relações coloniais no sul de Moçambique (1890-1930). Dissertação (Mestrado em História)- Universidade Federal Fulminense. Rio de Janeiro, 2008.

THOMAZ, Omar. Contextos Cosmopolitas: a sociedade colonial e a invenção de Moçambique 1930-1961. São Paulo. SEBRAP, 1999.

."Raça", nação e status: histórias de guerra e "relações raciais" em Moçambique. Revista USP. V, 68, 2006.

."Ecos do Atlântico Sul: Representação sobre o terceiro império português. Rio de Janeiro. Ed. UFRJ/FAPESP, 2002.

."Escravos sem dono:" experiência social dos campos de trabalho em Moçambique no período socialista. Revista de Antropologia. São Paulo: USP. V51, n1, 2008.

De desenvolvimento a desenvolvimento: entre as batatas e a getropha, 25 anos em Inhassune (Moçambique). IV CONGRESSO DA ASSOCIAÇÃO PORTUGUESA DE ANTROPOLOGIA "CLASSIFICAR O MUNDO."9 a 11 de Setembro de 2009. Lisboa. Resumo. Lisboa. ICS/ISCTE, 2009. Disponível em: <http://www.apantropologia.net>.Acesso em: 21 jun. 2010. 
UNOHAC. UNOHAC Map Series. Maputo, 1994

.UNCHS.State of the World's Cities 2001. Nairobi: United Nations Centre for Human Settlements Habitat, 2001.

UZOIGWE, Godfrey. Partilha europeia e conquista da África: apanhado geral. In: BOAHEN, Albert Ad (Ed.). História Geral da África VII: África sob dominação colonial, 1880-1935. Brasília: UNESCO, 2010.

VALÁ, Salim. Desenvolvimento rural em Moçambique. Um desafio ao nosso alcance. Maputo: Tipografia Peres, 2009

VALENTIM, Alexandre., JILL, Dias. O império africano, 1825-1890. Lisboa: Editorial Estampa. 1998.

VIERA, S. El Futuro Socialista de Moçambique. In: Revista Internacional.11/83.303, 1983.

VIERA, S. Participei, Por Isso Testemunho, 1ed, Ndjira, Maputo, 2010.

VIEIRA, S. Discurso sobre o “ homem novo". II reunião do Ministério de Educação eCultura. Doc. Inf. nº9 série ACEDIMO, 1979.

VIEIRA, S. Homem Novo. Maputo. Ed. Frelimo, 1978.

VINES, A. Renamo: Terrorism in Mozambique. New York: University ofyork,1991.

ZAWANGONI, S. A FRELIMO e a formação do Homem Novo (1964-1974 e 1975-1982). Maputo: CIEDIMA, 2007.

WEISSKOPF, T. E. A democratic enterprise-based market socialism. In: BARDHAN, P \& ROEMER, J. E. Market socialism: the current debate. Oford:Oxford University Press, 1993.

WEST, H. "Governem-se vocês mesmos?" democracia e carnificina no Norte de Moçambique. Análise Social, vol XLIII (2º, 2008.

WORLD BANK. Mozambique: Transport Sector Review, Washington, D. C, 1989.

WORLD BANK. Mozambique: Restoring Rural Production and Trade, Washington, D. C, 1990.

WORLD BANK. Mozambique: Second Public Expenditure Review, Washington, D. C, 1992.

WUYTS, Marc. "Moçambique: Economic Management and Adjustment Policies". The IMF and South.The Social Impact of Crisis and Adustment.Editado por Dhamb Ghaí. London, Zed Books Ltd. 1991.

.Economia Política do Colonialismo em Moçambique. Estudos Moçambicanos, Maputo, n. ${ }^{\circ}$ 1, Centro de Estudos Africanos, 1980. 
.Economic Crisis and Third Worrld Coutries: Impact and Response. Conferência proferida na United Nations Research Institute for Social Development. Jamaica, Kingston. 1989.

."Money and the Agrarian Question: The Mozambique Experiences". Financing and Economic Devolopment: A Sstructural A pproach to Monetary Policy. England, Hants, Gower. 1989.

.On the Question of Mechinization of Mozambican Agricultural Today: Some Theoretical Comments. Maputo, CEA. 1979.

.Camponeses e Economia Rural em Moçambique. Estudos Moçambicanos, Estudos Moçambicanos .n. ${ }^{\circ}$ 1. Maputo, Centro de Estudos Africanos."1978.

XAVIER, Inácio Caetano. Notícias dos domínios portugueses na costa da África Oriental. Lisboa: RMS-AMU, 1959.

ZAMPARONI, Valdemir. Entre narros e mulungos: colonialismo e paisagem social em Lourenço Marques c. 1890 e 1940. Tese. (Doutorado em História Social) - Faculdade de Filosofia, Letras e Ciências Humanas da Universidade de São Paulo. São Paulo, 1998.

Monhés, Baneanes, Chinas e Afromometanos: colonialismo e racismo em Lourenço Marques, Moçambique, 1890-1940. Lusotopie,2000,

- "Chibalo: Trabalho livre, trabalho escravo? As discussões em torno do trabalho compulsório em Moçambique colonial”. In: Escravatura e Transformação Culturais África - Brasil - Caraíbas.. Atas do Colóquio Internacional. Universidade de Évora. Lisboa. 2000

- “As 'Escravas Perpétuas' \& o 'Ensino Prático': Raça, Gênero e Educação no Moçambique Colonial, 1910-1930”. In:Revista de Estudos afro-asiáticos, Vol, 24, n. ${ }^{\circ} 1$. Rio de Janeiro editoral, Editor da UCAM, 2002. 